\title{
Copper-Mediated Radical-Polar Crossover Enables Photocatalytic Oxidative Functionalization of Sterically Bulky Alkenes
}

\author{
Nicholas L. Reed ${ }^{\dagger}$ Grace A. Lutovsky, $^{\dagger}$ Tehshik P. Yoon ${ }^{\dagger} *$ \\ † Department of Chemistry, University of Wisconsin-Madison, 1101 University Avenue, Madison, Wisconsin \\ 53706, United States
}

\section{Supporting Information}

\section{$\underline{\text { Table of Contents }}$}

$\begin{array}{lll}\text { I. } & \text { General Information } & \text { S1 } \\ \text { II. } & \text { Synthesis of Alkene Substrates } & \text { S2 } \\ \text { III. } & \text { Optimization Studies for Oxidative Amination } & \text { S19 } \\ \text { IV } & \text { Oxidative Heterofunctionalization Reactions } & \text { S20 } \\ \text { V. } & \text { Assignment of Relative Stereochemistry by Selective 1D NOESY } & \text { S30 } \\ \text { VI. } & \text { Cyclic Voltammetry Studies } & \text { S31 } \\ \text { VII. } & \text { Comparison to Pd(II)-Catalyzed Methods } & \text { S33 } \\ \text { VIII. } & \text { References } & \text { S34 } \\ \text { IX. } & \text { Spectral Data } & \text { S36 }\end{array}$

\section{General Information}

All reactions were performed under an $\mathrm{N}_{2}$ atmosphere unless otherwise stated. All glassware was dried in an oven at $120{ }^{\circ} \mathrm{C}$ for at least $2 \mathrm{~h}$ prior to use and allowed to cool in a desiccator cabinet. Reactions carried out below $0{ }^{\circ} \mathrm{C}$ employed an acetone/dry ice bath or a cryocool equipped with an acetone bath. $\mathrm{MeCN}$, THF, $\mathrm{Et} 2 \mathrm{O}$, DMF, toluene, and $\mathrm{CH}_{2} \mathrm{Cl}_{2}$ were purified by elution through alumina as described by Grubbs. ${ }^{1}$ 1,2-dichloroethane was distilled from $\mathrm{CaH}_{2}$. All other chemicals were purchased from commercial suppliers and used as received.

Flash column chromatography was performed with normal phase $\mathrm{SiO}_{2}$ (Sigma-Aldrich or Macherey-Nagel, $60 \AA$ pore size, 230-400 mesh, 40-63 $\mu \mathrm{m}$ particle size) according to the method of Still. ${ }^{2}$ Reactions were monitored by thin-layer chromatography (Silicycle, $250 \mu \mathrm{m}$ thickness), and visualization was accomplished with a $254 \mathrm{~nm}$ UV light or by staining with $\mathrm{KMnO}_{4}$ solution (3.0 $\mathrm{g}$ of $\mathrm{KMnO}_{4}$ and $20.0 \mathrm{~g}$ of $\mathrm{K}_{2} \mathrm{CO}_{3}$ in $5 \mathrm{~mL}$ of $5 \%$ aq. $\mathrm{NaOH}$ and $300 \mathrm{~mL} \mathrm{H}_{2} \mathrm{O}$ ).

${ }^{1} \mathrm{H}$ and ${ }^{13} \mathrm{C}\left\{{ }^{1} \mathrm{H}\right\}$ NMR data for all previously uncharacterized compounds were obtained using a Bruker AVANCE-400 or Bruker AVANCE-500 spectrometer with DCH, Prodigy, or BBFO+ probes. ${ }^{1} \mathrm{H}$ spectra were internally referenced to tetramethyl silane $(0.00 \mathrm{ppm})$ or the residual protio-solvent peak in DMSO- $d_{6} \cdot{ }^{13} \mathrm{C}\left\{{ }^{1} \mathrm{H}\right\}$ spectra were internally referenced to $\mathrm{CDCl}_{3}$ (77.16 ppm) or DMSO- $d_{6}(39.52 \mathrm{ppm}) .{ }^{1} \mathrm{H}$ NMR spectra were tabulated as follows: chemical shift, multiplicity $(\mathrm{s}=$ singlet, $\mathrm{d}=$ doublet, $\mathrm{t}=$ triplet, $\mathrm{q}=$ quartet, $\mathrm{p}=$ pentet, $\mathrm{dd}=$ doublet of doublets, $\mathrm{dt}=$ doublet of triplets, $\mathrm{m}=$ multiplet, $\mathrm{br}=$ broad), coupling constant $(\mathrm{s})$, and number of protons. ${ }^{13} \mathrm{C}$ NMR spectra were tabulated by observed peak. The spectrometers used for this work are supported by the NIH (S10 OD012245) and a generous gift from Paul J. and Margaret M. Bender. Mass spectrometry was performed with a Thermo Q Exactive ${ }^{\mathrm{TM}}$ Plus. This instrument is supported by the NIH (S10 OD020022) and the University of Wisconsin. IR spectra were obtained using a Bruker Alpha Platinum FTIR spectrometer equipped with an attenuated total reflectance (ATR) 
sampling head. Melting points were obtained using a Stanford Research Systems DigiMelt apparatus.

\section{Synthesis of Alkene Substrates}

2,2,5-Trimethylhex-4-enenitrile (SI, S1). A solution of $i$ - $\operatorname{Pr}_{2} \mathrm{NH}(4.52 \mathrm{~mL}, 32.0 \mathrm{mmol})$ in THF $(64 \mathrm{~mL})$ at $0{ }^{\circ} \mathrm{C}$ was treated dropwise via addition funnel with $n$-BuLi $(13.0 \mathrm{~mL}$,
$32.0 \mathrm{mmol})$ in hexanes $(2.46 \mathrm{M})$ over 10 minutes and the resulting solution was dropwise and the resulting solution was stirred at $0{ }^{\circ} \mathrm{C}$ for $15 \mathrm{~min}$. Prenyl bromide $(3.70 \mathrm{~mL}, 32.0$ mmol) was added dropwise and the resulting solution was stirred at $\mathrm{rt}$ for $17 \mathrm{~h}$. The reaction mixture was quenched with sat. aq. $\mathrm{NH}_{4} \mathrm{Cl}(200 \mathrm{~mL})$ and extracted with $\mathrm{Et}_{2} \mathrm{O}(3 \times 75 \mathrm{~mL})$. The combined organic extracts were washed with $\mathrm{H}_{2} \mathrm{O}(3 \mathrm{x})$ and brine $(3 \mathrm{x})$, dried over $\mathrm{MgSO}_{4}$, filtered, and concentrated under reduced pressure to give crude $\mathbf{S 1}(4.10 \mathrm{~g})$ as an orange oil which was used without further purification.

2,2,5-Trimethylhex-4-en-1-amine (SI, S2). To a suspension of $\mathrm{LiAlH}_{4}(2.27 \mathrm{~g}, 59.8 \mathrm{mmol})$ in

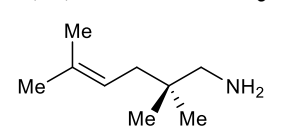
$\mathrm{Et}_{2} \mathrm{O}(80 \mathrm{~mL})$ at $0{ }^{\circ} \mathrm{C}$ was added a solution of $\mathbf{S 1}(4.10 \mathrm{~g})$ in $\mathrm{Et}_{2} \mathrm{O}(20 \mathrm{~mL})$ dropwise via addition funnel over 10 minutes and the resulting mixture was stirred at $\mathrm{rt}$ for $1.5 \mathrm{~h}$. The reaction mixture was cooled to $0{ }^{\circ} \mathrm{C}$ and quenched by dropwise addition of $3 \mathrm{M}$ aq. $\mathrm{NaOH}(20 \mathrm{~mL})$. The resulting mixture was stirred for $15 \mathrm{~min}$, dried over Na2SO4, filtered, and concentrated under reduced pressure to give S2 (4.04 g, $28.6 \mathrm{mmol}$, $89 \%$ over 2 steps) as a light yellow oil.

IR (ATR): $v$ 2958.2, 2920.5, 2864.6, 1569.1, 1463.6, 1371.8, $1312.0 \mathrm{~cm}^{-1} ;{ }^{1} \mathbf{H}$ NMR $(500 \mathrm{MHz}$, $\left.\mathrm{CDCl}_{3}\right): \delta 5.20-5.14(\mathrm{~m}, 1 \mathrm{H}), 2.44(\mathrm{~s}, 2 \mathrm{H}), 1.89(\mathrm{~d}, J=7.6 \mathrm{~Hz}, 2 \mathrm{H}), 1.72(\mathrm{~s}, 3 \mathrm{H}), 1.61(\mathrm{~s}, 3 \mathrm{H})$, $0.84(\mathrm{~s}, 6 \mathrm{H}) ;{ }^{13} \mathrm{C}$ NMR $\left(125 \mathrm{MHz}, \mathrm{CDCl}_{3}\right): \delta 133.1,120.9,52.9,37.8,35.9,26.2,24.8,18.0$; HRMS $\left(\mathrm{ESI}^{+}\right)$: $[\mathrm{M}+\mathrm{H}]^{+}$calculated for $\left[\mathrm{C}_{9} \mathrm{H}_{20} \mathrm{~N}\right]^{+}$required $142.1590 \mathrm{~m} / \mathrm{z}$, found $142.1594 \mathrm{~m} / \mathrm{z}$.

4-Methyl- $N$-(2,2,5-trimethylhex-4-en-1-yl)benzenesulfonamide (Table 1, 1). To a solution of

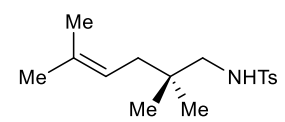
S2 (1.00 g, $7.08 \mathrm{mmol})$ and $\mathrm{Et}_{3} \mathrm{~N}(1.48 \mathrm{~mL}, 10.6 \mathrm{mmol})$ in $\mathrm{CH}_{2} \mathrm{Cl}_{2}(24 \mathrm{~mL})$ at 0 ${ }^{\circ} \mathrm{C}$ was added $\mathrm{TsCl}(1.48 \mathrm{~g}, 7.76 \mathrm{mmol})$ in a single portion and the resulting solution was stirred at $\mathrm{rt}$ for $2 \mathrm{~h}$. The reaction mixture was concentrated under reduced pressure, taken up in $\mathrm{Et}_{2} \mathrm{O}$, eluted through a thin pad of $\mathrm{SiO}_{2}$, and concentrated under reduced pressure to give crude $\mathbf{1}(2.10 \mathrm{~g})$ as a white solid. The crude solid was purified by chromatography on $\mathrm{SiO}_{2}$ (2-10\% EtOAc in hexanes) to give $\mathbf{1}(1.77 \mathrm{~g}, 5.98 \mathrm{mmol}, 84 \%)$ as a clear, colorless oil that solidified upon standing.

Mp 59-60 ${ }^{\circ} \mathrm{C}$; IR (ATR): v 3291.3, 3261.4, 2965.6, 2918.4, 2873.6, 1597.4, 1310.2, $1150.2 \mathrm{~cm}^{-1}$; ${ }^{1} \mathbf{H}$ NMR (400 MHz, $\left.\mathrm{CDCl}_{3}\right): \delta 7.76-7.69(\mathrm{~m}, 2 \mathrm{H}), 7.34-7.28(\mathrm{~m}, 2 \mathrm{H}), 5.04(\mathrm{tp}, J=7.7,1.4 \mathrm{~Hz}$, $1 \mathrm{H}), 4.43(\mathrm{t}, J=6.8 \mathrm{~Hz}, 1 \mathrm{H}), 2.68(\mathrm{~d}, J=6.8 \mathrm{~Hz}, 2 \mathrm{H}), 2.43(\mathrm{~s}, 3 \mathrm{H}), 1.86(\mathrm{~d}, J=7.7 \mathrm{~Hz}, 2 \mathrm{H})$, $1.67(\mathrm{~d}, J=1.3 \mathrm{~Hz}, 3 \mathrm{H}), 1.55$ (s, $3 \mathrm{H}), 0.84(\mathrm{~s}, 6 \mathrm{H}) ;{ }^{13} \mathbf{C ~ N M R}\left(100 \mathrm{MHz}, \mathrm{CDCl}_{3}\right): \delta 143.4,137.1$, 134.2, 129.8, 127.2, 119.8, 53.2, 38.0, 35.0, 26.2, 25.0, 21.7, 18.0; HRMS $\left(\mathrm{ESI}^{+}\right):[\mathrm{M}+\mathrm{H}]^{+}$ calculated for $\left[\mathrm{C}_{16} \mathrm{H}_{26} \mathrm{NO}_{2} \mathrm{~S}\right]^{+}$required $296.1679 \mathrm{~m} / \mathrm{z}$, found $296.1675 \mathrm{~m} / \mathrm{z}$. 
$N$-(2,2,5-Trimethylhex-4-en-1-yl)benzenesulfonamide (SI, S3). To a solution of S2 (0.500 g, $\overbrace{\mathrm{Me}}^{\mathrm{Me}} \overbrace{\mathrm{MHSO}_{2} \mathrm{Ph}}$ $3.54 \mathrm{mmol})$ and $\mathrm{Et}_{3} \mathrm{~N}(0.740 \mathrm{~mL}, 5.31 \mathrm{mmol})$ in $\mathrm{CH}_{2} \mathrm{Cl}_{2}(12 \mathrm{~mL})$ at $0{ }^{\circ} \mathrm{C}$ was added $\mathrm{PhSO}_{2} \mathrm{Cl}(0.500 \mathrm{~mL}, 3.89 \mathrm{mmol})$ via syringe and the resulting solution was stirred at $\mathrm{rt}$ for $3.5 \mathrm{~h}$. The reaction mixture was concentrated under reduced pressure, taken up in $\mathrm{Et}_{2} \mathrm{O}$, eluted through a thin pad of $\mathrm{SiO}_{2}$, and concentrated under reduced pressure to give crude $\mathbf{S 3}$ (1.02 g) as a light yellow oil. The crude residue was purified by chromatography on $\mathrm{SiO}_{2}$ (10-15\% EtOAc in hexanes) to give $\mathbf{S 3}(0.877 \mathrm{~g}, 3.11 \mathrm{mmol}, 88 \%)$ as a clear, colorless oil.

IR (ATR): v 3270.6, 2963.8, 2867.1, 1448.4, 1319.0, $1156.3 \mathrm{~cm}^{-1} ;{ }^{1} \mathbf{H}$ NMR (500 MHz, CDCl 3 ): $\delta$ 7.90-7.84 (m, $2 \mathrm{H}), 7.61-7.48(\mathrm{~m}, 3 \mathrm{H}), 5.04(\mathrm{tp}, J=7.6,1.4 \mathrm{~Hz}, 1 \mathrm{H}), 4.64(\mathrm{t}, J=6.6 \mathrm{~Hz}, 1 \mathrm{H})$, $2.70(\mathrm{~d}, J=6.8 \mathrm{~Hz}, 2 \mathrm{H}), 1.87(\mathrm{~d}, J=7.7 \mathrm{~Hz}, 2 \mathrm{H}), 1.67(\mathrm{~s}, 3 \mathrm{H}), 1.55(\mathrm{~s}, 3 \mathrm{H}), 0.84(\mathrm{~s}, 6 \mathrm{H}) ;{ }^{13} \mathrm{C}$ NMR (125 MHz, $\left.\mathrm{CDCl}_{3}\right): \delta 140.1,134.2,132.6,129.2,127.1,119.8,53.2,37.9,35.0,26.1,24.9$, 18.0; HRMS $\left(\mathrm{ESI}^{+}\right)$: $[\mathrm{M}+\mathrm{H}]^{+}$calculated for $\left[\mathrm{C}_{15} \mathrm{H}_{24} \mathrm{NO}_{2} \mathrm{~S}\right]^{+}$required $282.1522 \mathrm{~m} / \mathrm{z}$, found $282.1517 \mathrm{~m} / \mathrm{z}$.

4-(Trifluoromethyl)- $N$-(2,2,5-trimethylhex-4-en-1-yl)benzenesulfonamide (SI, S4). To a<smiles>CC(C)=CCC(C)(C)CNS(=O)(=O)c1ccc(C(F)(F)F)cc1</smiles>
solution of $\mathbf{S} 2(0.422 \mathrm{~g}, 2.99 \mathrm{mmol})$ and $\mathrm{Et}_{3} \mathrm{~N}(0.615 \mathrm{~mL}, 4.48 \mathrm{mmol})$ in $\mathrm{CH}_{2} \mathrm{Cl}_{2} \quad(10 \mathrm{~mL})$ at $0{ }^{\circ} \mathrm{C}$ was added 4(trifluoromethyl)benzenesulfonyl chloride $(0.810 \mathrm{~g}, 3.31 \mathrm{mmol})$ in a single portion and the resulting solution was stirred at $\mathrm{rt}$ for $2 \mathrm{~h}$. The reaction mixture was concentrated under reduced pressure, taken up in $\mathrm{Et}_{2} \mathrm{O}$, eluted through a thin pad of $\mathrm{SiO}_{2}$, and concentrated under reduced pressure to give crude $\mathbf{S 4}$ (1.04 g) as a light yellow solid. The crude solid was purified by chromatography on $\mathrm{SiO}_{2}(15 \%$ EtOAc in hexanes) to give S4 (0.826 g, $2.36 \mathrm{mmol}, 79 \%)$ as an off-white solid.

Mp 78-79 ${ }^{\circ} \mathrm{C}$; IR (ATR): v 3270.5, 2970.8, 2933.1, 1608.7, 1319.4 $\mathrm{cm}^{-1} ;{ }^{1} \mathbf{H}$ NMR (500 MHz, $\left.\mathrm{CDCl}_{3}\right): \delta 7.99(\mathrm{~d}, J=8.2 \mathrm{~Hz}, 2 \mathrm{H}), 7.79(\mathrm{~d}, J=8.2 \mathrm{~Hz}, 2 \mathrm{H}), 5.04(\mathrm{ddt}, J=7.7,6.3,1.5 \mathrm{~Hz}, 1 \mathrm{H})$, $4.67(\mathrm{t}, J=6.7 \mathrm{~Hz}, 1 \mathrm{H}), 2.74(\mathrm{~d}, J=6.2 \mathrm{~Hz}, 2 \mathrm{H}), 1.87(\mathrm{~d}, J=7.6 \mathrm{~Hz}, 2 \mathrm{H}), 1.68(\mathrm{~s}, 3 \mathrm{H}), 1.55$ (s, $3 \mathrm{H}), 0.85(\mathrm{~s}, 6 \mathrm{H}) ;{ }^{13} \mathbf{C} \mathbf{N M R}\left(125 \mathrm{MHz} \mathrm{CDCl}_{3}\right): \delta 143.8(\mathrm{q}, J=1.4 \mathrm{~Hz}), 134.5,134.4(\mathrm{q}, J=$ $33.0 \mathrm{~Hz}, 127.7,126.4(\mathrm{q}, J=3.7 \mathrm{~Hz}), 123.4$ (q, $J=272.9), 119.6,55.3,37.9,35.1,26.1,25.0,18.0$; HRMS $\left(\mathrm{ESI}^{+}\right):[\mathrm{M}+\mathrm{H}]^{+}$calculated for $\left[\mathrm{C}_{16} \mathrm{H}_{23} \mathrm{~F}_{3} \mathrm{NO}_{2} \mathrm{~S}\right]^{+}$required $350.1396 \mathrm{~m} / \mathrm{z}$, found 350.1388 $m / z$.

4-Methoxy- $N$-(2,2,5-trimethylhex-4-en-1-yl)benzenesulfonamide (SI, S5). To a solution of S2<smiles>COc1ccc(S(=O)(=O)NCC(C)(C)CC=C(C)C)cc1</smiles>
$(1.01 \mathrm{~g}, 7.15 \mathrm{mmol})$ and $\mathrm{Et}_{3} \mathrm{~N}(1.48 \mathrm{~mL}, 10.6 \mathrm{mmol})$ in $\mathrm{CH}_{2} \mathrm{Cl}_{2} \quad(24$ $\mathrm{mL})$ at $0{ }^{\circ} \mathrm{C}$ was added 4 -(methoxy)benzenesulfonyl chloride $(1.62 \mathrm{~g}$, $7.84 \mathrm{mmol})$ in a single portion and the resulting solution was stirred at $\mathrm{rt}$ for $2.5 \mathrm{~h}$. The reaction mixture was concentrated under reduced pressure, taken up in $\mathrm{Et}_{2} \mathrm{O}$, eluted through a thin pad of $\mathrm{SiO}_{2}$, and concentrated under reduced pressure to give crude S5 (2.253 g) as a clear, light yellow oil. The crude residue was purified by chromatography on $\mathrm{SiO}_{2}$ (15\% EtOAc in hexanes) to give $\mathbf{S 5}(2.01 \mathrm{~g}, 6.45 \mathrm{mmol}, 90 \%)$ as a clear, colorless oil.

IR (ATR): $v$ 3283.0, 2961.8, 2919.4, 1594.2, $1151.0 \mathrm{~cm}^{-1} ;{ }^{\mathbf{1}} \mathbf{H} \mathbf{~ N M R}\left(500 \mathrm{MHz}, \mathrm{CDCl}_{3}\right): \delta 7.85-$ $7.73(\mathrm{~m}, 2 \mathrm{H}), 7.01-6.95(\mathrm{~m}, 2 \mathrm{H}), 5.04(\mathrm{tt}, J=7.7,1.4 \mathrm{~Hz}, 1 \mathrm{H}) ; 4.51(\mathrm{t}, J=6.8 \mathrm{~Hz}, 1 \mathrm{H}), 3.87(\mathrm{~s}$, 
$3 \mathrm{H}), 2.67(\mathrm{~d}, J=6.8 \mathrm{~Hz}, 2 \mathrm{H}), 1.86(\mathrm{~d}, J=7.6 \mathrm{~Hz}, 2 \mathrm{H}), 1.67(\mathrm{~d}, J=1.2 \mathrm{~Hz}, 3 \mathrm{H}), 1.55(\mathrm{~s}, 3 \mathrm{H})$, $0.83(\mathrm{~s}, 6 \mathrm{H}) ;{ }^{13} \mathrm{C}$ NMR $\left(125 \mathrm{MHz}, \mathrm{CDCl}_{3}\right): \delta 162.9,134.2,131.7,129.3,119.9,114.3,55.7,53.1$, 38.0, 35.0, 26.2, 25.0, 18.0; HRMS $\left(\mathrm{ESI}^{+}\right):[\mathrm{M}+\mathrm{H}]^{+}$calculated for $\left[\mathrm{C}_{16} \mathrm{H}_{26} \mathrm{NO}_{3} \mathrm{~S}\right]^{+}$required $312.1628 \mathrm{~m} / \mathrm{z}$, found $312.1623 \mathrm{~m} / \mathrm{z}$.

2-Methyl- $N$-(2,2,5-trimethylhex-4-en-1-yl)benzenesulfonamide (SI, S6). To a solution of S2

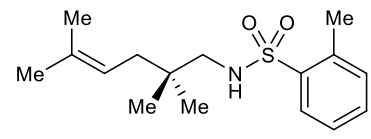
$(0.498 \mathrm{~g}, 3.53 \mathrm{mmol})$ and $\mathrm{Et}_{3} \mathrm{~N}(0.740 \mathrm{~mL}, 5.31 \mathrm{mmol})$ in $\mathrm{CH}_{2} \mathrm{Cl}_{2}(18 \mathrm{~mL})$ at $0{ }^{\circ} \mathrm{C}$ was added $o$-toluenesulfonyl chloride $(0.560 \mathrm{~g}, 3.89 \mathrm{mmol})$ in a single portion and the resulting solution was stirred at $\mathrm{rt}$ for $17 \mathrm{~h}$. The reaction mixture was concentrated under reduced pressure, taken up in $\mathrm{Et}_{2} \mathrm{O}$, eluted through a thin pad of $\mathrm{SiO}_{2}$, and concentrated under reduced pressure to give crude $\mathbf{S 6}$ $(1.09 \mathrm{~g})$ as a yellow oil. The crude residue was purified by chromatography on $\mathrm{SiO}_{2}\left(10-20 \% \mathrm{Et}_{2} \mathrm{O}\right.$ in hexanes) to give $\mathbf{S 6}(0.900 \mathrm{~g}, 3.05 \mathrm{mmol}, 86 \%)$ as a clear, colorless oil.

IR (ATR): $v$ 3304.5, 2964.7, 2925.1, 2875.7, 1462.1, 1321.0, $1159.4 \mathrm{~cm}^{-1} ;{ }^{1} \mathbf{H}$ NMR $(500 \mathrm{MHz}$, $\left.\mathrm{CDCl}_{3}\right): \delta$ 7.99-7.92 (m, $\left.1 \mathrm{H}\right), 7.49-7.42(\mathrm{~m}, 1 \mathrm{H}), 7.35-7.28(\mathrm{~m}, 2 \mathrm{H}), 5.02(\mathrm{tp}, J=7.7,1.5 \mathrm{~Hz}$, $1 \mathrm{H}), 4.42(\mathrm{t}, J=6.9 \mathrm{~Hz}, 1 \mathrm{H}), 2.68(\mathrm{~d}, J=6.8 \mathrm{~Hz}, 2 \mathrm{H}), 2.65(\mathrm{~s}, 3 \mathrm{H}), 1.85(\mathrm{~d}, J=7.6 \mathrm{~Hz}, 2 \mathrm{H})$, $1.67(\mathrm{~d}, J=1.4 \mathrm{~Hz}, 3 \mathrm{H}), 1.56(\mathrm{~s}, 3 \mathrm{H}), 0.82(\mathrm{~s}, 6 \mathrm{H}) ;{ }^{13} \mathbf{C} \mathbf{~ N M R}\left(125 \mathrm{MHz}, \mathrm{CDCl}_{3}\right): \delta$ 137.9, 137.0, 134.3, 132.8, 132.6, 129.8, 126.3, 119.8, 53.0, 38.0, 35.0, 26.2, 25.1, 20.4, 18.0; HRMS (ESI ${ }^{+}$): $[\mathrm{M}+\mathrm{H}]^{+}$calculated for $\left[\mathrm{C}_{16} \mathrm{H}_{26} \mathrm{NO}_{2} \mathrm{~S}\right]^{+}$required $296.1679 \mathrm{~m} / \mathrm{z}$, found $296.1675 \mathrm{~m} / \mathrm{z}$.

4-Nitro- $N$-(2,2,5-trimethylhex-4-en-1-yl)benzenesulfonamide (SI, S7). To a solution of S2

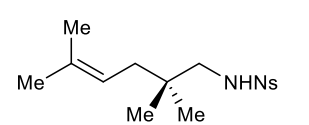
$(0.505 \mathrm{~g}, 4.46 \mathrm{mmol})$ and $\mathrm{Et}_{3} \mathrm{~N}(0.924 \mathrm{~mL}, 4.86 \mathrm{mmol})$ in $\mathrm{CH}_{2} \mathrm{Cl}_{2}(15 \mathrm{~mL})$ at 0 ${ }^{\circ} \mathrm{C}$ was added 2- $\mathrm{NsCl}(1.10 \mathrm{~g}, 4.96 \mathrm{mmol})$ in a single portion and the resulting solution was stirred at $\mathrm{rt}$ for $1 \mathrm{~h}$. The reaction mixture was concentrated under reduced pressure, taken up in $\mathrm{Et}_{2} \mathrm{O}$, eluted through a thin pad of $\mathrm{SiO}_{2}$, and concentrated under reduced pressure to give crude $\mathbf{S} 7(1.42 \mathrm{~g})$ as a yellow oil. The crude residue was purified by chromatography on $\mathrm{SiO}_{2}$ (20\% EtOAc in hexanes) to give $\mathbf{S 7}(1.04 \mathrm{~g}, 3.20 \mathrm{mmol}, 72 \%)$ as a milky yellow oil.

IR (ATR): v 3359.7, 2962.5, 1590.5, 1539.2, 1351.2, $1166.9 \mathrm{~cm}^{-1} ;{ }^{1} \mathbf{H} \mathbf{~ N M R}\left(500 \mathrm{MHz}, \mathrm{CDCl}_{3}\right)$ : $\delta$ 8.15-8.09 (m, $1 \mathrm{H}), 7.89-7.83(\mathrm{~m}, 1 \mathrm{H}), 7.77-7.71(\mathrm{~m}, 2 \mathrm{H}), 5.30(\mathrm{t}, J=6.6 \mathrm{~Hz}, 1 \mathrm{H}), 5.13-5.06$ $(\mathrm{m}, 1 \mathrm{H}), 2.84(\mathrm{~d}, J=6.5 \mathrm{~Hz}, 2 \mathrm{H}), 1.92(\mathrm{~d}, J=7.7 \mathrm{~Hz}, 2 \mathrm{H}), 1.70(\mathrm{~s}, 3 \mathrm{H}), 1.59(\mathrm{~s}, 3 \mathrm{H}), 0.89$ (s, $6 \mathrm{H}) ;{ }^{13} \mathrm{C}$ NMR $\left(125 \mathrm{MHz}, \mathrm{CDCl}_{3}\right): \delta 148.2,134.6,133.8,133.6,132.9,131.2,125.5,119.6,53.6$, 38.0, 35.2, 26.2, 25.1, 18.0; HRMS $\left(\mathrm{ESI}^{+}\right):[\mathrm{M}+\mathrm{H}]^{+}$calculated for $\left[\mathrm{C}_{15} \mathrm{H}_{23} \mathrm{~N}_{2} \mathrm{O}_{4} \mathrm{~S}\right]^{+}$required $327.1373 \mathrm{~m} / \mathrm{z}$, found $327.1369 \mathrm{~m} / \mathrm{z}$.

1-Phenyl- $N$-(2,2,5-trimethylhex-4-en-1-yl)methanesulfonamide (SI, S8). To a solution of S2<smiles>CC(C)=CCC(C)CCNC(=O)NS(=O)(=O)Cc1ccccc1</smiles>
$(0.502 \mathrm{~g}, 3.56 \mathrm{mmol})$ and $\mathrm{Et}_{3} \mathrm{~N}(0.740 \mathrm{~mL}, 5.31 \mathrm{mmol})$ in $\mathrm{CH}_{2} \mathrm{Cl}_{2}(12$ $\mathrm{mL})$ at $0{ }^{\circ} \mathrm{C}$ was added phenylmethanesulfonyl chloride $(0.746 \mathrm{~g}, 3.91$ $\mathrm{mmol}$ ) in a single portion and the resulting solution was stirred at $\mathrm{rt}$ for 1 $\mathrm{h}$. The reaction mixture was concentrated under reduced pressure, taken up in $\mathrm{Et}_{2} \mathrm{O}$, eluted through a thin pad of $\mathrm{SiO}_{2}$, and concentrated under reduced pressure to give crude $\mathbf{S 8}$ as a white powder. The crude residue was purified by chromatography on $\mathrm{SiO}_{2}\left(30 \% \mathrm{Et}_{2} \mathrm{O}\right.$ in hexanes) to give $\mathbf{S 8}$ $(0.876 \mathrm{~g}, 2.97 \mathrm{mmol}, 83 \%)$ as a white solid. 
Mp 95-96 ${ }^{\circ} \mathrm{C}$; IR (ATR): v 3276.2, 2959.9, 2920.2, 1446.7, 1317.7, $1132.7 \mathrm{~cm}^{-1} ;{ }^{1} \mathbf{H}$ NMR (400 $\left.\mathrm{MHz} \mathrm{CDCl}_{3}\right): \delta 7.48-7.32(\mathrm{~m}, 5 \mathrm{H}), 5.08(\mathrm{ddt}, J=7.7,6.3,1.5 \mathrm{~Hz}, 1 \mathrm{H}), 4.25(\mathrm{~s}, 2 \mathrm{H}), 4.02(\mathrm{t}, J$ $=6.6 \mathrm{~Hz}, 1 \mathrm{H}), 2.79(\mathrm{~d}, J=6.7 \mathrm{~Hz}, 2 \mathrm{H}), 1.86(\mathrm{~d}, J=7.7 \mathrm{~Hz}, 2 \mathrm{H}), 1.70(\mathrm{~d}, J=1.3 \mathrm{~Hz}, 3 \mathrm{H}), 1.55$ $(\mathrm{s}, 3, \mathrm{H}), 0.86(\mathrm{~s}, 6 \mathrm{H}) ;{ }^{13} \mathrm{C}$ NMR $\left(125 \mathrm{MHz}, \mathrm{CDCl}_{3}\right)$ : $\delta 134.3,130.7,129.6,129.0,128.9,119.8$, 58.6, 53.6, 38.0, 35.2, 26.2, 24.9, 18.0; HRMS $\left(\mathrm{ESI}^{+}\right)$: $[\mathrm{M}+\mathrm{H}]^{+}$calculated for $\left[\mathrm{C}_{16} \mathrm{H}_{26} \mathrm{NO}_{2} \mathrm{~S}^{+}\right.$ required $296.1679 \mathrm{~m} / \mathrm{z}$, found $296.1676 \mathrm{~m} / \mathrm{z}$.

$N$-(2,2,5-Trimethylhex-4-en-1-yl)cyclopropanesulfonamide (SI, S9). To a solution of S2 (0.502 Me $\quad$ g, $3.55 \mathrm{mmol})$ and $\mathrm{Et}_{3} \mathrm{~N}(0.740 \mathrm{~mL}, 5.31 \mathrm{mmol})$ in $\mathrm{CH}_{2} \mathrm{Cl}_{2}(18 \mathrm{~mL})$ at $0{ }^{\circ} \mathrm{C}$ was added cyclopropylsulfonyl chloride $(0.400 \mathrm{~g}, 3.89 \mathrm{mmol})$ in a single portion and the resulting solution was stirred at $\mathrm{rt}$ for $15 \mathrm{~h}$. The reaction mixture was concentrated under reduced pressure, taken up in $\mathrm{Et}_{2} \mathrm{O}$, eluted through a thin pad of $\mathrm{SiO}_{2}$, and concentrated under reduced pressure to give crude $\mathbf{S 9}(1.00 \mathrm{~g})$ as a clear, yellow oil. The crude residue was purified by chromatography on $\mathrm{SiO}_{2}\left(40 \% \mathrm{Et}_{2} \mathrm{O}\right.$ in hexanes) to give $\mathbf{S 9}$ (0.768 g, $3.13 \mathrm{mmol}, 89 \%$ ) as a clear, colorless oil.

IR (ATR): $v$ 3287.9, 2963.4, 2920.9, 2872.0, 1425.0, 1323.3, $1145.2 \mathrm{~cm}^{-1} ;{ }^{1} \mathbf{H}$ NMR (400 MHz, DMSO- $\left.d_{6}\right): \delta 6.91(\mathrm{t}, J=6.7 \mathrm{~Hz}, 1 \mathrm{H}), 5.17(\mathrm{t}, J=7.8 \mathrm{~Hz}, 1 \mathrm{H}), 2.76(\mathrm{~d}, J=6.7 \mathrm{~Hz}, 2 \mathrm{H}), 1.87(\mathrm{~d}$, $J=7.7 \mathrm{~Hz}, 2 \mathrm{H}), 1.69(\mathrm{~s}, 3 \mathrm{H}), 1.57(\mathrm{~s}, 3 \mathrm{H}), 0.92-0.88(\mathrm{~m}, 4 \mathrm{H}), 0.81(\mathrm{~s}, 6 \mathrm{H}) ;{ }^{13} \mathrm{C}$ NMR $(125$ MHz, DMSO- $\left.d_{6}\right): \delta 132.6,120.5,52.6,37.3,35.0,29.1,25.9,24.5,17.7,4.4$; HRMS $\left(\mathrm{ESI}^{+}\right)$: $[\mathrm{M}+\mathrm{H}]^{+}$calculated for $\left[\mathrm{C}_{12} \mathrm{H}_{24} \mathrm{NO}_{2} \mathrm{~S}\right]^{+}$required $246.1522 \mathrm{~m} / \mathrm{z}$, found $246.1524 \mathrm{~m} / \mathrm{z}$.

2-Methyl- $N$-(2,2,5-trimethylhex-4-en-1-yl)propane-2-sulfinamide (SI, S10). To a solution of<smiles>CC(C)=CCC(C)(C)CNS(=O)C(C)(C)C</smiles>
S2 $(0.550 \mathrm{~g}, 3.89 \mathrm{mmol})$ and $\mathrm{Et}_{3} \mathrm{~N}(0.810 \mathrm{~mL}, 5.84 \mathrm{mmol})$ in $\mathrm{CH}_{2} \mathrm{Cl}_{2}(20$ $\mathrm{mL})$ at $0{ }^{\circ} \mathrm{C}$ was added tert-butyl sulfinyl chloride $(0.450 \mathrm{~mL}, 4.28 \mathrm{mmol})$ in a single portion and the resulting solution was stirred at $\mathrm{rt}$ for $20 \mathrm{~h}$. The reaction mixture was concentrated under reduced pressure, taken up in $\mathrm{Et}_{2} \mathrm{O}$, eluted through a thin pad of Celite, and concentrated under reduced pressure to give $\mathbf{S 1 0}(0.953 \mathrm{~g}, 3.88 \mathrm{mmol}, 100 \%)$ as a yellow oil.

IR (ATR): v 3214.0, 2956.3, 2921.6, 2859.3, 1462.2, $1058.1 \mathrm{~cm}^{-1} ;{ }^{1} \mathbf{H}$ NMR (500 MHz, CDCl 3 ): $\delta 5.16(\mathrm{tp}, J=7.6,1.5 \mathrm{~Hz}, 1 \mathrm{H}), 3.21(\mathrm{dd}, J=9.4,5.2 \mathrm{~Hz}, 1 \mathrm{H}), 3.03(\mathrm{dd}, J=12.8,5.2 \mathrm{~Hz}, 1 \mathrm{H})$, $2.80(\mathrm{dd}, J=12.8,9.4 \mathrm{~Hz}, 1 \mathrm{H}), 1.92(\mathrm{~d}, J=7.7 \mathrm{~Hz}, 2 \mathrm{H}), 1.72(\mathrm{~s}, 3 \mathrm{H}), 1.61(\mathrm{~s}, 3 \mathrm{H}), 1.23$ (s, 9 $\mathrm{H}), 0.88(\mathrm{~s}, 6 \mathrm{H}) ;{ }^{13} \mathrm{C}$ NMR $\left(125 \mathrm{MHz}, \mathrm{CDCl}_{3}\right): \delta 133.8,120.4,56.0,55.9,38.2,36.0,26.2,25.3$, 25.1, 22.9, 18.1; HRMS $\left(\mathrm{ESI}^{+}\right):[\mathrm{M}+\mathrm{H}]^{+}$calculated for $\left[\mathrm{C}_{13} \mathrm{H}_{28} \mathrm{NOS}\right]^{+}$required $246.1886 \mathrm{~m} / \mathrm{z}$, found $246.1885 \mathrm{~m} / \mathrm{z}$.

2-Methyl- $N$-(2,2,5-trimethylhex-4-en-1-yl)propane-2-sulfonamide (SI, S11). To a solution of

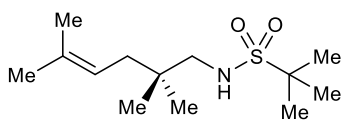
$\mathbf{S 1 0}(0.693 \mathrm{~g}, 2.82 \mathrm{mmol})$ in $\mathrm{CH}_{2} \mathrm{Cl}_{2}(10 \mathrm{~mL})$ at $-78^{\circ} \mathrm{C}$ was added a solution of peroxyacetic acid $\left(0.825 \mathrm{~g}, 4.23 \mathrm{mmol}, 39 \%\right.$ in acetic acid) in $\mathrm{CH}_{2} \mathrm{Cl}_{2}$ (4 $\mathrm{mL}$ ) and the resulting solution was stirred at $-78{ }^{\circ} \mathrm{C}$ for $2 \mathrm{~h}$, warmed to -40 ${ }^{\circ} \mathrm{C}$ and stirred for $2 \mathrm{~h}$, and warmed to $0^{\circ} \mathrm{C}$ and stirred for $1 \mathrm{~h}$. The reaction mixture was quenched by addition of sat. aq. $\mathrm{NaHCO}_{3}(30 \mathrm{~mL})$ and $\mathrm{H}_{2} \mathrm{O}(50 \mathrm{~mL})$ and the layers were separated. The aqueous phase was extracted with $\mathrm{CH}_{2} \mathrm{Cl}_{2}(2 \times 50 \mathrm{~mL})$ and the combined organic extracts were dried over $\mathrm{Na}_{2} \mathrm{SO}_{4}$, filtered, and concentrated under reduced pressure to give crude $\mathbf{S 1 1}(0.863 \mathrm{~g})$ 
as a yellow oil. The crude residue was purified by chromatography on $\mathrm{SiO}_{2}(10 \% \mathrm{EtOAc}$ in hexanes) to give $\mathbf{S 1 1}$ (0.105 g, $0.402 \mathrm{mmol}, 14 \%$ ) as a white, crystalline solid.

Mp 71-73 ${ }^{\circ} \mathrm{C}$; IR (ATR): v 3300.0, 2967.4, 2919.5, 1456.9, 1307.9, $1128.2 \mathrm{~cm}^{-1} ;{ }^{\mathbf{1}} \mathbf{H}$ NMR $(500$ $\left.\mathrm{MHz}, \mathrm{CDCl}_{3}\right): \delta 5.21-5.13(\mathrm{~m}, 1 \mathrm{H}), 3.86(\mathrm{t}, J=6.3 \mathrm{~Hz}, 1 \mathrm{H}), 2.98(\mathrm{~d}, J=6.3 \mathrm{~Hz}, 2 \mathrm{H}), 1.94(\mathrm{~d}, J$ $=7.7 \mathrm{~Hz}, 2 \mathrm{H}), 1.73(\mathrm{~s}, 3 \mathrm{H}), 1.62(\mathrm{~s}, 3 \mathrm{H}), 1.40(\mathrm{~s}, 9 \mathrm{H}), 0.92$ (s, $6 \mathrm{H}) ;{ }^{13} \mathbf{C ~ N M R}(125 \mathrm{MHz}$, $\left.\mathrm{CDCl}_{3}\right): \delta 134.4,120.0,60.2,55.1,38.2,35.5,26.2,25.0,24.7,18.1$; HRMS $\left(\mathrm{ESI}^{+}\right):[\mathrm{M}+\mathrm{Na}]^{+}$ calculated for $\left[\mathrm{C}_{13} \mathrm{H}_{27} \mathrm{NO}_{2} \mathrm{SNa}\right]^{+}$required $294.1655 \mathrm{~m} / \mathrm{z}$, found $294.1653 \mathrm{~m} / \mathrm{z}$.

$N$-(2,2,5-trimethylhex-4-en-1-yl)- $N$ ', $N$ '-dimethyl sulfuric diamide (SI, S12). To a solution of $\mathrm{S2}(0.340 \mathrm{~g}, 2.65 \mathrm{mmol})$ and $\mathrm{Et}_{3} \mathrm{~N}(0.500 \mathrm{~mL}, 3.61 \mathrm{mmol})$ in $\mathrm{CH}_{2} \mathrm{Cl}_{2}(12$
$\mathrm{mL})$ at $0{ }^{\circ} \mathrm{C}$ was added $N, N$-dimethylsulfamoyl chloride $(0.275 \mathrm{~mL}, 2.65$ reaction mixture was concentrated under reduced pressure, taken up in $\mathrm{Et}_{2} \mathrm{O}$, eluted through a thin pad of $\mathrm{SiO}_{2}$, and concentrated under reduced pressure to give crude $\mathbf{S 1 2}(0.588 \mathrm{~g})$ as a clear, colorless oil. The crude residue was purified by chromatography on $\mathrm{SiO}_{2}$ (30-100\% EtOAc in hexanes) to give $\mathbf{S 1 2}$ (0.387 g, $1.56 \mathrm{mmol}, 65 \%)$ as a clear, colorless oil.

IR (ATR): $v$ 3296.9, 2920.6, 2877.4, 1458.5, $1324.6 \mathrm{~cm}^{-1} ;{ }^{\mathbf{1}} \mathbf{H}$ NMR (500 MHz, $\left.\mathrm{CDCl}_{3}\right): \delta 5.18$ (tp, $J=7.6,1.4 \mathrm{~Hz}, 1 \mathrm{H}), 4.09$ (br. s, $1 \mathrm{H}), 2.86$ (d, $J=6.7 \mathrm{~Hz}, 2 \mathrm{H}), 2.84$ (s, $6 \mathrm{H}), 1.95$ (d, $J=7.7$ $\mathrm{Hz}, 2 \mathrm{H}), 1.75$ (s, $3 \mathrm{H}), 1.64$ (s, $3 \mathrm{H}), 0.94$ (s, $6 \mathrm{H}) ;{ }^{13} \mathbf{C ~ N M R}\left(125 \mathrm{MHz}, \mathrm{CDCl}_{3}\right): \delta$ 134.3, 119.9 , 53.7, 38.2, 38.2, 35.0, 26.2, 25.1, 18.1; HRMS $\left(\mathrm{ESI}^{+}\right)$: $[\mathrm{M}+\mathrm{H}]^{+}$calculated for $\left[\mathrm{C}_{11} \mathrm{H}_{25} \mathrm{~N}_{2} \mathrm{O}_{2} \mathrm{~S}\right]^{+}$ required $249.1631 \mathrm{~m} / \mathrm{z}$, found $249.1628 \mathrm{~m} / \mathrm{z}$.

5-Methyl-2,2-diphenylhex-4-en-1-ol (SI, S13). Synthesized according to the method of Melchiorre and coworkers. All spectral data were in agreement with previously $\overbrace{\mathrm{Ph}=\mathrm{Ph}}^{\mathrm{OH}}$ reported values. ${ }^{3}$

5-Methyl-2,2-diphenylhex-4-enoic acid (SI, S14). Synthesized according to the method of Melchiorre and coworkers. All spectral data were in agreement with previously $\overbrace{\mathrm{Ph}}^{\mathrm{M}=\mathrm{OH}}$ reported values. $^{3}$

Dimethyl 2-(3-methylbut-2-en-1-yl)malonate (SI, S15). Synthesized according to the method of if If Sher and Mook, Jr. All spectral data were in agreement with previously reported мео

Dimethyl 2-((1,3-dioxoisoindolin-2-yl)methyl)-2-(3-methylbut-2-en-1-yl)malonate (SI, S16).

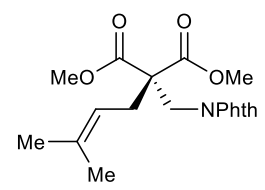

To a suspension of $\mathrm{NaH}(1.59 \mathrm{~g}, 42.3 \mathrm{mmol}, 60 \%$ dispersion in mineral oil $)$ in THF (42 mL) at $0{ }^{\circ} \mathrm{C}$ was added a solution of $\mathbf{S 1 5}(5.80 \mathrm{~g}, 29.0 \mathrm{mmol})$ in THF $(11 \mathrm{~mL})$ dropwise via syringe and the resulting solution was stirred at $0{ }^{\circ} \mathrm{C}$ for 30 min. $N$-(Chloromethyl)phthalimide $(5.15 \mathrm{~g}, 26.3 \mathrm{mmol})$ was added in a single portion and the resulting solution was stirred at $\mathrm{rt}$ for $16 \mathrm{~h}$. The reaction mixture 
was quenched by dropwise addition of sat. aq. $\mathrm{NH}_{4} \mathrm{Cl}(100 \mathrm{~mL})$ at $0{ }^{\circ} \mathrm{C}$ and extracted with $\mathrm{Et}_{2} \mathrm{O}$ $(3 \times 50 \mathrm{~mL})$. The combined organic extracts were dried over $\mathrm{MgSO}_{4}$, filtered, and concentrated under reduced pressure to give crude $\mathbf{S 1 6}$ (7.68 g) as a white solid which was used without further purification.

Dimethyl 2-(aminomethyl)-2-(3-methylbut-2-en-1-yl)malonate (SI, S17). A solution of S16

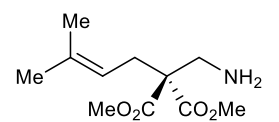
$(6.00 \mathrm{~g})$ and $\mathrm{N}_{2} \mathrm{H}_{4} \cdot \mathrm{H}_{2} \mathrm{O}(0.890 \mathrm{~mL}, 18.4 \mathrm{mmol})$ in $\mathrm{MeOH}(42 \mathrm{~mL})$ was stirred at reflux for $4 \mathrm{~h}$. The mixture was quenched with $10 \%$ aq. $\mathrm{NaOH}(100 \mathrm{~mL})$ and extracted with $\mathrm{Et}_{2} \mathrm{O}(3 \times 50 \mathrm{~mL})$. The combined organic extracts were washed with $\mathrm{H}_{2} \mathrm{O}$ and brine, dried over $\mathrm{Na}_{2} \mathrm{SO}_{4}$, filtered, and concentrated under reduced pressure to give crude $\mathbf{S 1 7}$ (3.62 g) as a clear, colorless oil.

Dimethyl 2-(3-methylbut-2-en-1-yl)-2-(((4-methylphenyl)sulfonamido)methyl)malonate (SI,

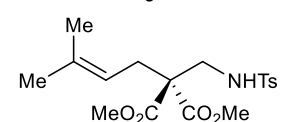
S18). To a solution of $\mathbf{S 1 7}$ (3.62 g) and $\mathrm{Et}_{3} \mathrm{~N}$ (3.30 mL, $23.7 \mathrm{mmol}$ ) in $\mathrm{CH}_{2} \mathrm{Cl}_{2}$ $(80 \mathrm{~mL})$ at $0{ }^{\circ} \mathrm{C}$ was added $\mathrm{TsCl}(3.32 \mathrm{~g}, 17.4 \mathrm{mmol})$ in a single portion and the resulting solution was stirred at $\mathrm{rt}$ for $15 \mathrm{~h}$. The reaction mixture was concentrated under reduced pressure, taken up in $\mathrm{Et}_{2} \mathrm{O}$, eluted through a thin pad of $\mathrm{SiO}_{2}$, and concentrated under reduced pressure to give crude $\mathbf{S 1 8}(5.53 \mathrm{~g})$ as a white solid. The crude solid was purified by chromatography on $\mathrm{SiO}_{2}$ (20-40\% EtOAc in hexanes) to give $\mathbf{S 1 8}$ (3.45 g, 9.00 mmol, $21 \%$ over 3 steps) as a white solid.

Mp 116-118 ${ }^{\circ} \mathrm{C}$; IR (ATR): v 3252.6, 3056.8, 2956.8, 1731.0, $1596.3 \mathrm{~cm}^{-1}$; ${ }^{1} \mathbf{H}$ NMR (500 MHz, $\left.\mathrm{CDCl}_{3}\right): \delta 7.72(\mathrm{~d}, J=8.3 \mathrm{~Hz}, 2 \mathrm{H}), 7.31(\mathrm{~d}, J=8.4 \mathrm{~Hz}, 2 \mathrm{H}), 5.07(\mathrm{t}, J=7.0 \mathrm{~Hz}, 1 \mathrm{H}), 4.88(\mathrm{~m}, 1$ $\mathrm{H}), 3.70(\mathrm{~s}, 6 \mathrm{H}), 3.31(\mathrm{~d}, J=7.0 \mathrm{~Hz}, 2 \mathrm{H}), 2.64(\mathrm{~d}, J=7.5 \mathrm{~Hz}, 2 \mathrm{H}), 2.43(\mathrm{~s}, 3 \mathrm{H}), 1.65(\mathrm{~s}, 3 \mathrm{H})$, $1.60(\mathrm{~s}, 3 \mathrm{H}) ;{ }^{13} \mathbf{C} \mathbf{N M R}\left(125 \mathrm{MHz}, \mathrm{CDCl}_{3}\right): \delta 170.7,143.6,137.1,129.9,127.2,116.7,58.5,52.9$, 45.9, 31.4, 26.1, 21.7, 18.1; HRMS $\left(\mathrm{ESI}^{+}\right)$: $[\mathrm{M}+\mathrm{H}]^{+}$calculated for $\left[\mathrm{C}_{18} \mathrm{H}_{26} \mathrm{NO}_{6} \mathrm{~S}\right]^{+}$required $383.1475 \mathrm{~m} / \mathrm{z}$, found $383.1468 \mathrm{~m} / \mathrm{z}$.

$N$-(2,2-bis(Hydroxymethyl)-5-methylhex-4-en-1-yl)-4-methylbenzenesulfonamide (SI, S19). To a solution of $\mathbf{S 1 8}(0.505 \mathrm{~g}, 1.32 \mathrm{mmol})$ in $\mathrm{CH}_{2} \mathrm{Cl}_{2}(6.5 \mathrm{~mL})$ at $-78{ }^{\circ} \mathrm{C}$ was
added a solution of DIBAL-H $(1.40 \mathrm{~mL}, 7.80 \mathrm{mmol})$ in toluene $(4 \mathrm{~mL})$ dropwise aq. Rochelle's salt (30 mL) was added and the resulting solution was stirred at $\mathrm{rt}$ for $30 \mathrm{~min} .6 \mathrm{M}$ aq. $\mathrm{HCl}$ was added until $\mathrm{pH} 2$ and the mixture was extracted with $\mathrm{CH}_{2} \mathrm{Cl}_{2}(3 \mathrm{x})$. The combined organic extracts were washed with brine, dried over $\mathrm{Na}_{2} \mathrm{SO}_{4}$, filtered, and concentrated under reduced pressure to give crude $\mathbf{S 1 9}(0.449 \mathrm{~g})$ as a clear, yellow oil. The crude residue was purified by chromatography on $\mathrm{SiO}_{2}(60 \%$ EtOAc in hexanes) to give $\mathbf{S 1 9}(0.264 \mathrm{~g}, 0.806 \mathrm{mmol}, 61 \%)$ as a clear, colorless oil.

IR (ATR): v 3484.7, 3282.6, 2922.9, 1598.3, 1323.1, $1156.8 \mathrm{~cm}^{-1} ;{ }^{\mathbf{1}} \mathbf{H}$ NMR $\left(500 \mathrm{MHz}, \mathrm{CDCl}_{3}\right)$ : $\delta 7.78-7.68(\mathrm{~m}, 2 \mathrm{H}), 7.32(\mathrm{~d}, J=8.0 \mathrm{~Hz}, 2 \mathrm{H}), 5.04-4.99(\mathrm{~m}, 2 \mathrm{H}), 3.64(\mathrm{dd}, J=11.4,5.0 \mathrm{~Hz}, 2$ H), $3.59(\mathrm{dd}, J=11.4,6.3 \mathrm{~Hz}, 2 \mathrm{H}), 3.02(\mathrm{~d}, J=6.9 \mathrm{~Hz}, 2 \mathrm{H}), 2.60(\mathrm{t}, J=6.0 \mathrm{~Hz}, 2 \mathrm{H}), 2.44(\mathrm{~s}, 3$ $\mathrm{H}), 1.88(\mathrm{~d}, J=7.8 \mathrm{~Hz}, 2 \mathrm{H}), 1.69(\mathrm{~s}, 3 \mathrm{H}), 1.59(\mathrm{~s}, 3 \mathrm{H}) ;{ }^{13} \mathbf{C ~ N M R}\left(125 \mathrm{MHz}, \mathrm{CDCl}_{3}\right): \delta 143.8$, 136.8, 135.6, 130.0, 127.1, 118.0, 66.6, 45.4, 43.8, 29.7, 26.2, 21.7, 18.0; HRMS $\left(\mathrm{ESI}^{+}\right):[\mathrm{M}+\mathrm{H}]^{+}$ calculated for $\left[\mathrm{C}_{16} \mathrm{H}_{26} \mathrm{NO}_{4} \mathrm{~S}\right]^{+}$required $328.1577 \mathrm{~m} / \mathrm{z}$, found $328.1573 \mathrm{~m} / \mathrm{z}$. 


\section{$N$-(2,2-bis(((tert-Butyldimethylsilyl)oxy)methyl)-5-methylhex-4-en-1-yl)-4-}

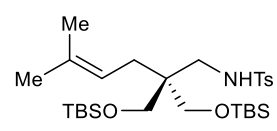

methylbenzenesulfonamide (SI, S20). To a solution of S19 (0.327 g, 1.00 mmol) and imidazole $(0.205 \mathrm{~g}, 3.01 \mathrm{mmol})$ in $\mathrm{CH}_{2} \mathrm{Cl}_{2}(4.5 \mathrm{~mL})$ at $\mathrm{rt}$ was added a solution of TBSCl $(0.376 \mathrm{~g}, 2.49 \mathrm{mmol})$ in $\mathrm{CH}_{2} \mathrm{Cl}_{2}(1.5 \mathrm{~mL})$ dropwise via syringe and the resulting solution was stirred at $\mathrm{rt}$ for $16 \mathrm{~h}$. The mixture was diluted with $\mathrm{CH}_{2} \mathrm{Cl}_{2}$ $(20 \mathrm{~mL})$ and washed with aq. $\mathrm{NaHCO}_{3}(20 \mathrm{~mL})$. The organic phase was dried over $\mathrm{MgSO}_{4}$, filtered, and concentrated under reduced pressure to give crude $\mathbf{S 2 0}(0.583 \mathrm{~g})$ as a clear, colorless oil. The crude residue was purified by chromatography on $\mathrm{SiO}_{2}$ (10\% EtOAc in hexanes) to give $\mathbf{S 2 0}$ (0.439 $\mathrm{g}, 0.790 \mathrm{mmol}, 79 \%$ ) as a clear, colorless oil.

IR (ATR): v 3286.2, 2953.6, 2929.6, 2858.5, $1465.7 \mathrm{~cm}^{-1} ;{ }^{1} \mathbf{H} \mathbf{N M R}\left(500 \mathrm{MHz}, \mathrm{CDCl}_{3}\right): \delta 7.73-$ $7.67(\mathrm{~m}, 2 \mathrm{H}), 7.31-7.26(\mathrm{~m}, 2 \mathrm{H}), 5.49(\mathrm{t}, J=5.8 \mathrm{~Hz}, 1 \mathrm{H}), 5.05-4.96(\mathrm{~m}, 1 \mathrm{H}), 3.40(\mathrm{ABq}, J=$ $9.9 \mathrm{~Hz}, 2 \mathrm{H}), 3.38(\mathrm{ABq}, J=9.9 \mathrm{~Hz}, 2 \mathrm{H}), 2.85(\mathrm{~d}, J=5.9 \mathrm{~Hz}, 2 \mathrm{H}), 2.42(\mathrm{~s}, 3 \mathrm{H}), 1.94(\mathrm{~d}, J=7.7$ $\mathrm{Hz}, 2 \mathrm{H}), 1.68(\mathrm{~d}, J=1.4 \mathrm{~Hz}, 3 \mathrm{H}), 1.56(\mathrm{~s}, 3 \mathrm{H}), 0.86(\mathrm{~s}, 18 \mathrm{H}), 0.01(\mathrm{~s}, 12 \mathrm{H}) ;{ }^{13} \mathrm{C} \mathrm{NMR}(125$ $\left.\mathrm{MHz}_{\mathrm{CDCl}}\right): \delta 143.1,136.9,134.8,129.7,127.3,118.8,65.4,48.0,43.4,29.2,26.2,26.0,21.6$, 18.2, 18.1, -5.5, -5.6; HRMS $\left(\mathrm{ESI}^{+}\right):[\mathrm{M}+\mathrm{H}]^{+}$calculated for $\left[\mathrm{C}_{28} \mathrm{H}_{54} \mathrm{NO}_{4} \mathrm{SSi}_{2}\right]^{+}$required 556.3307 $\mathrm{m} / \mathrm{z}$, found $556.3306 \mathrm{~m} / \mathrm{z}$.

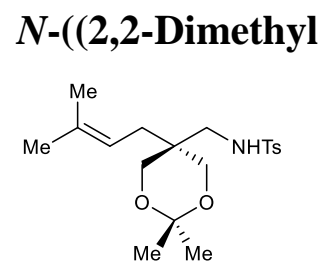

l-5-(3-methylbut-2-en-1-yl)-1,3-dioxan-5-yl)methyl)-4-

methylbenzenesulfonamide (SI, S21). A solution of $\mathbf{S 1 9}(0.340 \mathrm{~g}, 1.04 \mathrm{mmol})$, 2-methoxypropene $(0.300 \mathrm{~mL}, 3.12 \mathrm{mmol})$, and $p$-toluenesulfonic acid monohydrate $(0.020 \mathrm{~g}, 0.11 \mathrm{mmol})$ in $\mathrm{CH}_{2} \mathrm{Cl}_{2}(2.10 \mathrm{~mL})$ was stirred at $\mathrm{rt}$ for 1 h. The reaction mixture was diluted with $\mathrm{H}_{2} \mathrm{O}(20 \mathrm{~mL})$ and extracted with $\mathrm{Et}_{2} \mathrm{O}$ $(3 \times 30 \mathrm{~mL})$. The combined organic extracts were washed with brine $(50 \mathrm{~mL})$ and concentrated under reduced pressure to give crude $\mathbf{S 2 1}(0.735 \mathrm{~g})$ as a yellow oil. The crude residue was purified by chromatography on $\mathrm{SiO}_{2}$ (30\% EtOAc in hexanes) to give $\mathbf{S 2 1}(0.254 \mathrm{~g}$, $0.691 \mathrm{mmol}, 66 \%$ ) as a white, crystalline solid.

Mp 104-106 ${ }^{\circ} \mathrm{C}$; IR (ATR): v 3281.2, 2988.1, 2926.2, 2868.4, 1598.2, $1156.2 \mathrm{~cm}^{-1}$; ${ }^{\mathbf{1}} \mathbf{H}$ NMR $\left(500 \mathrm{MHz}, \mathrm{CDCl}_{3}\right): \delta$ 7.78-7.72 (m, $\left.2 \mathrm{H}\right), 7.34-7.29(\mathrm{~m}, 2 \mathrm{H}), 5.03-4.94(\mathrm{~m}, 1 \mathrm{H}), 4.67(\mathrm{t}, J=6.8$ $\mathrm{Hz}, 1 \mathrm{H}), 3.62(\mathrm{~d}, J=12.3 \mathrm{~Hz}, 2 \mathrm{H}), 3.51(\mathrm{~d}, J=12.3 \mathrm{~Hz}, 2 \mathrm{H}), 3.00(\mathrm{~d}, J=6.8 \mathrm{~Hz}, 2 \mathrm{H}), 2.43$ (s, $3 \mathrm{H}), 1.96(\mathrm{~d}, J=7.7 \mathrm{~Hz}, 2 \mathrm{H}), 1.69(\mathrm{~d}, J=1.4 \mathrm{~Hz}, 3 \mathrm{H}), 1.59(\mathrm{~s}, 3 \mathrm{H}), 1.38(\mathrm{~s}, 3 \mathrm{H}), 1.32(\mathrm{~s}, 3 \mathrm{H})$; ${ }^{13} \mathrm{C}$ NMR $\left(125 \mathrm{MHz}, \mathrm{CDCl}_{3}\right): \delta 143.5,136.8,136.0,129.8,127.3,117.3,98.5,65.8,46.1,36.9$, 30.5, 26.4, 26.1, 21.7, 21.2, 18.0; HRMS $\left(\mathrm{ESI}^{+}\right)$: $[\mathrm{M}+\mathrm{H}]^{+}$calculated for $\left[\mathrm{C}_{19} \mathrm{H}_{30} \mathrm{NO}_{4} \mathrm{~S}\right]^{+}$required $368.1890 \mathrm{~m} / \mathrm{z}$, found $368.1885 \mathrm{~m} / \mathrm{z}$.

5-Methylhex-4-enenitrile (SI, S22). To a solution of MeCN $(0.370 \mathrm{~mL}, 7.04 \mathrm{mmol})$ in THF (18 Me $\mathrm{mL})$ at $-78{ }^{\circ} \mathrm{C}$ was added a solution of $n$-BuLi $(2.90 \mathrm{~mL}, 7.25 \mathrm{mmol})$ in hexanes Me ${ }^{\mathrm{CN}}(2.5 \mathrm{M})$ and the resulting solution was stirred at $-78{ }^{\circ} \mathrm{C}$ for $15 \mathrm{~min}$. A solution of prenyl bromide $(1.00 \mathrm{~mL}, 8.66 \mathrm{mmol})$ in THF $(9 \mathrm{~mL})$ was added dropwise via syringe and the resulting solution was warmed to $\mathrm{rt}$ and stirred for $2 \mathrm{~h}$. The reaction mixture was quenched with sat. aq. $\mathrm{NH}_{4} \mathrm{Cl}(50 \mathrm{~mL})$ and extracted with $\mathrm{Et}_{2} \mathrm{O}(3 \times 50 \mathrm{~mL})$. The combined organic extracts were washed with $\mathrm{H}_{2} \mathrm{O}$ and brine, dried over $\mathrm{MgSO}_{4}$, filtered, and concentrated under reduced pressure to give crude $\mathbf{S 2 2}$ (1.05 g) as a yellow oil which was used without further purification. 
5-Methylhex-4-en-1-amine (SI, S23). To a suspension of $\mathrm{LiAlH}_{4}(0.657 \mathrm{~g}, 17.3 \mathrm{mmol})$ in $\mathrm{Et}_{2} \mathrm{O}$ Me $\quad(34 \mathrm{~mL})$ at $0{ }^{\circ} \mathrm{C}$ was added a solution of crude $\mathbf{S 2 2}(1.05 \mathrm{~g})$ in $\mathrm{Et}_{2} \mathrm{O}(9 \mathrm{~mL})$ and ме $\sim_{\mathrm{NH}_{2}}$ the resulting solution was stirred at $\mathrm{rt}$ for $2 \mathrm{~h}$. The reaction mixture was cooled to $0{ }^{\circ} \mathrm{C}$ and quenched by dropwise addition of $3 \mathrm{M}$ aq. $\mathrm{NaOH}(10 \mathrm{~mL})$. The resulting mixture was stirred for $15 \mathrm{~min}$, dried over $\mathrm{Na}_{2} \mathrm{SO}_{4}$, filtered, and concentrated under reduced pressure to give crude $\mathbf{S 2 3}$ (0.371 g) as a green oil which was used without further purification.

4-Methyl- $N$-(5-methylhex-4-en-1-yl)benzenesulfonamide (SI, S24). To a solution of crude $\mathbf{S 2 3}$ Me $\quad(0.371 \mathrm{~g})$ and $\mathrm{Et}_{3} \mathrm{~N}(0.685 \mathrm{~g}, 4.92 \mathrm{mmol})$ in $\mathrm{CH}_{2} \mathrm{Cl}_{2}(11 \mathrm{~mL})$ at $0{ }^{\circ} \mathrm{C}$ was added ${ }_{\mathrm{NHTs}} \mathrm{TsCl}(0.687 \mathrm{~g}, 3.60 \mathrm{mmol})$ in a single portion and the resulting solution was stirred at $\mathrm{rt}$ for $1 \mathrm{~h}$. The reaction mixture was concentrated under reduced pressure, taken up in $\mathrm{Et}_{2} \mathrm{O}$, eluted through a thin pad of $\mathrm{SiO}_{2}$, and concentrated under reduced pressure to give crude S24 $(0.917 \mathrm{~g})$ as a yellow oil. The crude residue was purified by chromatography on $\mathrm{SiO}_{2}(15 \%$ EtOAc in hexanes) to give $\mathbf{S 2 4}$ (0.520 g, $1.94 \mathrm{mmol}, 22 \%$ over $3 \mathrm{steps})$ as a clear, light yellow oil.

IR (ATR): $v$ 3281.3, 2925.5, 2867.1, 1598.2, 1321.6, $1153.0 \mathrm{~cm}^{-1} ;{ }^{1} \mathbf{H}$ NMR (500 MHz, $\left.\mathrm{CDCl}_{3}\right)$ :

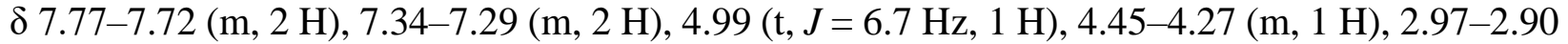
$(\mathrm{m}, 2 \mathrm{H}), 2.43(\mathrm{~s}, 3 \mathrm{H}), 1.95$ (q, J = 7.3 Hz, $2 \mathrm{H}), 1.65(\mathrm{~s}, 3 \mathrm{H}), 1.54$ (s, $3 \mathrm{H}), 1.49$ (p, J = 7.2 Hz, $2 \mathrm{H}) ;{ }^{13} \mathrm{C}$ NMR $\left(125 \mathrm{MHz}, \mathrm{CDCl}_{3}\right): \delta 143.5,137.1,133.0,129.8,127.2,123.0,43.1,29.7,25.8$, 25.2, 21.7, 17.8; HRMS $\left(\mathrm{ESI}^{+}\right):[\mathrm{M}+\mathrm{H}]^{+}$calculated for $\left[\mathrm{C}_{14} \mathrm{H}_{22} \mathrm{NO}_{2} \mathrm{~S}\right]^{+}$required $268.1366 \mathrm{~m} / \mathrm{z}$, found $268.1364 \mathrm{~m} / \mathrm{z}$.

$N$-(2-Hydroxyethyl)-4-methylbenzenesulfonamide (SI, S25). Synthesized according to the но ${ }^{\text {NHTs }}$ method of Aubineau and Cossy. All spectral data were in agreement with previously reported values. ${ }^{5}$

4-Methyl- $N$-(2-((3-methylbut-2-en-1-yl)oxy)ethyl)benzenesulfonamide (SI, S26). To a<smiles>CC=C(C)CCNCCCC</smiles>
solution of $\mathbf{S 2 5}(1.00 \mathrm{~g}, 4.64 \mathrm{mmol})$ in THF $(9 \mathrm{~mL})$ at $\mathrm{rt}$ was added $\mathrm{NaH}(0.186$ $\mathrm{g}, 4.64 \mathrm{mmol}, 60 \%$ dispersion in mineral oil) in a single portion and the resulting solution was stirred at $\mathrm{rt}$ for $1 \mathrm{~h}$. Prenyl bromide $(0.540 \mathrm{~mL}, 4.64$ $\mathrm{mmol}$ ) was added dropwise via syringe and the resulting solution was stirred at $\mathrm{rt}$ for $15 \mathrm{~h}$. The reaction mixture was quenched with $6 \mathrm{M}$ aq. $\mathrm{NaOH}(50 \mathrm{~mL})$ and extracted with $\mathrm{CH}_{2} \mathrm{Cl}_{2}(3 \mathrm{x})$. The combined organic extracts were washed with brine (2x), dried over $\mathrm{MgSO}_{4}$, filtered, and concentrated under reduced pressure to give $\mathbf{S 2 6}(0.712 \mathrm{~g})$ as a yellow oil. The crude residue was purified by chromatography on $\mathrm{SiO}_{2}$ (25-30\% EtOAc in hexanes) to give $\mathbf{S 2 6}$ (0.303 g, $1.07 \mathrm{mmol}$, $23 \%)$ as a clear, colorless oil.

IR (ATR): $v$ 3520.1, 2924.9, 1598.1, 1376.3, $1154.5 \mathrm{~cm}^{-1} ;{ }^{1} \mathbf{H}$ NMR $\left(500 \mathrm{MHz}, \mathrm{CDCl}_{3}\right): \delta 7.75-$ 7.67 (m, 2 H), 7.35-7.28 (m, 2 H), 5.03 (tp, $J=7.1,1.5 \mathrm{~Hz}, 1 \mathrm{H}), 3.84$ (d, $J=7.1 \mathrm{~Hz}, 2 \mathrm{H}), 3.72$ $(\mathrm{q}, J=5.0 \mathrm{~Hz}, 2 \mathrm{H}), 3.20(\mathrm{t}, J=5.3 \mathrm{~Hz}, 2 \mathrm{H}), 2.44(\mathrm{~s}, 3 \mathrm{H}), 2.27(\mathrm{t}, J=5.6 \mathrm{~Hz}, 1 \mathrm{H}), 1.70-1.66$ $(\mathrm{m}, 3 \mathrm{H}), 1.63(\mathrm{~s}, 3 \mathrm{H}) ;{ }^{13} \mathbf{C}$ NMR $\left(125 \mathrm{MHz}, \mathrm{CDCl}_{3}\right): \delta 143.6,137.7,136.5,129.8,127.5,119.0$, 61.4, 49.9, 47.2, 25.9, 21.7, 18.0; HRMS $\left(\mathrm{ESI}^{+}\right):[\mathrm{M}+\mathrm{H}]^{+}$calculated for $\left[\mathrm{C}_{14} \mathrm{H}_{22} \mathrm{NO}_{3} \mathrm{~S}\right]^{+}$required $284.1315 \mathrm{~m} / \mathrm{z}$, found $284.1307 \mathrm{~m} / \mathrm{z}$. 
1-(tert-Butyl) 4-methyl 4-(3-methylbut-2-en-1-yl)piperidine-1,4-dicarboxylate (SI, S27). To a<smiles>CC(C)=CCC1(CO)CC[NH2+]CC1</smiles>
solution of $i-\mathrm{Pr}_{2} \mathrm{NH}(3.50 \mathrm{~mL}, 24.7 \mathrm{mmol})$ in $\mathrm{THF}(40 \mathrm{~mL})$ at $-78{ }^{\circ} \mathrm{C}$ was added a solution of $n$-BuLi $(9.90 \mathrm{~mL}, 24.8 \mathrm{mmol})$ in hexanes $(2.5 \mathrm{M})$ dropwise via addition funnel and the resulting solution was stirred at $-78{ }^{\circ} \mathrm{C}$ for $1 \mathrm{~h}$. A solution of 1- $N$-Boc-4-piperidinecarboxylic acid methyl ester (5.02 g, $20.6 \mathrm{mmol})$ in THF $(10 \mathrm{~mL})$ was added dropwise via addition funnel and the resulting solution was stirred at $-78{ }^{\circ} \mathrm{C}$ for $1 \mathrm{~h}$. Prenyl bromide $(2.85 \mathrm{~mL}, 24.7 \mathrm{mmol})$ was added dropwise and the resulting solution was stirred at $\mathrm{rt}$ for $1 \mathrm{~h}$. The reaction mixture was quenched with sat. aq. $\mathrm{NH}_{4} \mathrm{Cl}$ $(100 \mathrm{~mL})$ and extracted with $\mathrm{Et}_{2} \mathrm{O}(3 \times 100 \mathrm{~mL})$. The combined organic extracts were washed with $\mathrm{H}_{2} \mathrm{O}(2 \mathrm{x})$ and brine $(2 \mathrm{x})$, dried over $\mathrm{MgSO}_{4}$, filtered, and concentrated under reduced pressure to give crude $\mathbf{S 2 7}$ (6.22 g) as a yellow oil which was used without further purification.

Methyl 4-(3-methylbut-2-en-1-yl)piperidine-4-carboxylate (SI, S28). A solution of crude S27

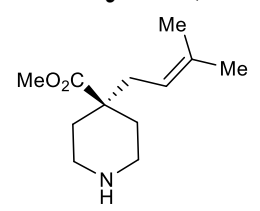

(6.07 g, $19.5 \mathrm{mmol})$ and trifluoroacetic acid (7.50 mL, $97.5 \mathrm{mmol})$ in $\mathrm{CH}_{2} \mathrm{Cl}_{2}$ (20

$\mathrm{mL})$ was stirred at $\mathrm{rt}$ for $1 \mathrm{~h}$. The reaction mixture was diluted with $\mathrm{H}_{2} \mathrm{O}(100 \mathrm{~mL})$

and $1 \mathrm{M}$ aq. $\mathrm{NaOH}$ was added to $\mathrm{pH} 12$. The layers were separated and the aqueous phase was extracted with $\mathrm{Et}_{2} \mathrm{O}(3 \times 100 \mathrm{~mL})$ and the combined organic extracts were dried over $\mathrm{Na}_{2} \mathrm{SO}_{4}$, filtered, and concentrated under reduced pressure to give crude $\mathbf{S 2 8}$ (4.60 g) as a yellow oil which was used without further purification.

Methyl 1-benzoyl-4-(3-methylbut-2-en-1-yl)piperidine-4-carboxylate (SI, S29). To a solution

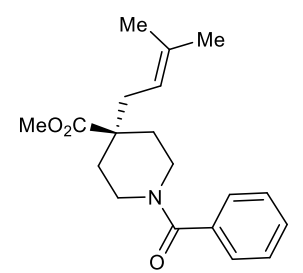
of $\mathbf{S 2 8}(0.401 \mathrm{~g}, 1.90 \mathrm{mmol})$ and $\mathrm{Et}_{3} \mathrm{~N}(0.400 \mathrm{~mL}, 2.84 \mathrm{mmol})$ in $\mathrm{CH}_{2} \mathrm{Cl}_{2}(9.60$ $\mathrm{mL})$ was added benzoyl chloride $(0.240 \mathrm{~mL}, 2.08 \mathrm{mmol})$ dropwise via syringe and the resulting solution was stirred at $\mathrm{rt}$ for $20 \mathrm{~h}$. The reaction mixture was diluted with $\mathrm{CH}_{2} \mathrm{Cl}_{2}(100 \mathrm{~mL})$ and washed with $1 \mathrm{M}$ aq. $\mathrm{HCl}(2 \mathrm{x})$. The organic phase was dried over $\mathrm{Na}_{2} \mathrm{SO}_{4}$, filtered, and concentrated under reduced pressure to give crude $\mathbf{S 2 9}(0.625 \mathrm{~g})$ as a yellow oil. The crude oil was purified by chromatography on $\mathrm{SiO}_{2}\left(70 \% \mathrm{Et}_{2} \mathrm{O}\right.$ in hexanes) to give $\mathbf{S 2 9}(0.423 \mathrm{~g}, 1.34 \mathrm{mmol}, 71 \%)$ as a clear, colorless oil.

(1-Benzyl-4-(3-methylbut-2-en-1-yl)piperidin-4-yl)methanol (SI, S30). To a suspension of

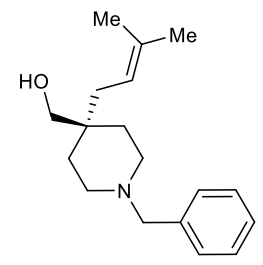
$\mathrm{LiAlH}_{4}(0.254 \mathrm{~g}, 6.69 \mathrm{mmol})$ in $\mathrm{Et}_{2} \mathrm{O}(3 \mathrm{~mL})$ at $0{ }^{\circ} \mathrm{C}$ was added a solution of $\mathbf{S 2 9}$ $(0.522 \mathrm{~g}, 1.66 \mathrm{mmol})$ in $\mathrm{Et}_{2} \mathrm{O}(2.50 \mathrm{~mL})$ dropwise via syringe and the resulting solution was stirred at $\mathrm{rt}$ for $1 \mathrm{~h}$. The reaction mixture was cooled to $0{ }^{\circ} \mathrm{C}$, quenched with $1 \mathrm{M}$ aq. $\mathrm{NaOH}(5 \mathrm{~mL})$, and stirred for $15 \mathrm{~min}$. The mixture was diluted with $\mathrm{Et}_{2} \mathrm{O}(20 \mathrm{~mL})$, dried over $\mathrm{Na}_{2} \mathrm{SO}_{4}$, filtered, and concentrated under reduced pressure to give crude $\mathbf{S 3 0}(0.422 \mathrm{~g})$. Further drying in vacuo gave $\mathbf{S 3 0}$ $(0.380 \mathrm{~g}, 1.39 \mathrm{mmol}, 84 \%)$ as a light yellow solid.

Mp 66-67 ${ }^{\circ} \mathrm{C}$; IR (ATR): v 3355.5, 2913.3, 2808.6, 2766.6, 1446.6, $1048.3 \mathrm{~cm}^{-1} ;{ }^{\mathbf{1}} \mathbf{H}$ NMR (500 $\left.\mathrm{MHz}, \mathrm{CDCl}_{3}\right): \delta 7.35-7.28(\mathrm{~m}, 4 \mathrm{H}), 7.27-7.21(\mathrm{~m}, 1 \mathrm{H}), 5.20(\mathrm{ddq}, J=7.7,6.3,1.4 \mathrm{~Hz}, 1 \mathrm{H})$, $3.51(\mathrm{~s}, 2 \mathrm{H}), 3.44(\mathrm{~s}, 2 \mathrm{H}), 2.41(\mathrm{t}, J=5.7 \mathrm{~Hz}, 4 \mathrm{H}), 2.07(\mathrm{~d}, J=7.7 \mathrm{~Hz}, 2 \mathrm{H}), 1.72(\mathrm{~s}, 3 \mathrm{H}), 1.65$ $(\mathrm{s}, 3 \mathrm{H}), 1.50(\mathrm{~m}, 4 \mathrm{H}), 1.42$ (br. s, $1 \mathrm{H}) ;{ }^{13} \mathbf{C} \mathbf{N M R}\left(125 \mathrm{MHz}, \mathrm{CDCl}_{3}\right): \delta 138.6,134.0,129.3$, 128.3, 127.1, 120.1, 68.3, 63.7, 49.5, 36.8, 33.9, 32.1, 26.3, 18.1; HRMS $\left(\mathrm{ESI}^{+}\right):[\mathrm{M}+\mathrm{H}]^{+}$ calculated for $\left[\mathrm{C}_{18} \mathrm{H}_{28} \mathrm{NO}\right]^{+}$required $274.2165 \mathrm{~m} / \mathrm{z}$, found $274.2160 \mathrm{~m} / \mathrm{z}$. 
Methyl 4-(3-methylbut-2-en-1-yl)-1-phenylpiperidine-4-carboxylate (SI, S31). A solution of

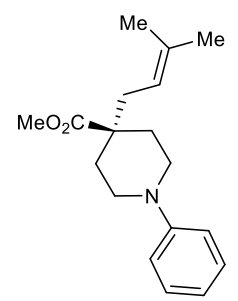
S28 $(0.501 \mathrm{~g}, 2.37 \mathrm{mmol})$, chlorobenzene $(0.200 \mathrm{~mL}, 2.00 \mathrm{mmol}), \mathrm{NaO} t-\mathrm{Bu}(0.231$ g, $2.40 \mathrm{mmol})$, RuPhos $(0.0047 \mathrm{~g}, 0.010 \mathrm{mmol})$, and RuPhos Pd G1 methyl tertbutyl ether adduct $(0.0081 \mathrm{~g}, 0.010 \mathrm{mmol})$ in THF $(4 \mathrm{~mL})$ was stirred at $85^{\circ} \mathrm{C}$ for $20 \mathrm{~h}$. The reaction mixture was cooled to rt, diluted with $\mathrm{CH}_{2} \mathrm{Cl}_{2}(50 \mathrm{~mL})$, washed with $\mathrm{H}_{2} \mathrm{O}(2 \mathrm{x})$, dried over $\mathrm{Na}_{2} \mathrm{SO}_{4}$, filtered, and concentrated under reduced pressure to give a brown oil $(0.557 \mathrm{~g})$. The oil was taken up in $\mathrm{Et}_{2} \mathrm{O}$, eluted through a thin pad of $\mathrm{SiO}_{2}$, and concentrated under reduced pressure to give crude $\mathbf{S 3 1}$ $(0.367 \mathrm{~g})$ as a yellow oil which was used without further purification.

(4-(3-Methylbut-2-en-1-yl)-1-phenylpiperidin-4-yl)methanol (SI, S32). To a suspension of

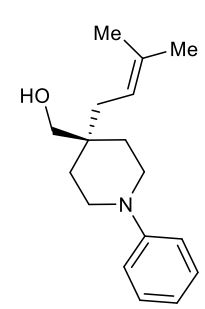
$\mathrm{LiAlH}_{4}(0.135 \mathrm{~g}, 3.56 \mathrm{mmol})$ in $\mathrm{Et}_{2} \mathrm{O}(6 \mathrm{~mL})$ at $0{ }^{\circ} \mathrm{C}$ was added a solution of $\mathbf{S 3 1}$ $(0.516 \mathrm{~g}, 1.80 \mathrm{mmol})$ in $\mathrm{Et}_{2} \mathrm{O}(3 \mathrm{~mL})$ dropwise via syringe and the resulting solution was stirred at $\mathrm{rt}$ for $1 \mathrm{~h}$. The reaction mixture was cooled to $0{ }^{\circ} \mathrm{C}$, quenched by dropwise addition of $3 \mathrm{M}$ aq. $\mathrm{NaOH}(5 \mathrm{~mL})$, and stirred for $15 \mathrm{~min}$. The mixture was diluted with $\mathrm{Et}_{2} \mathrm{O}(20 \mathrm{~mL})$, dried over $\mathrm{Na}_{2} \mathrm{SO}_{4}$, filtered, and concentrated under reduced pressure to give crude $\mathbf{S 3 2}(0.399 \mathrm{~g})$ as a clear yellow oil. The crude oil was purified by chromatography on $\mathrm{SiO}_{2}(20 \%$ EtOAc in hexanes) to give $\mathbf{S 3 2}(0.314 \mathrm{~g}$, $1.21 \mathrm{mmol}, 61 \%$ over 2 steps) as a clear, colorless oil.

Mp 66-67 ${ }^{\circ} \mathrm{C}$; IR (ATR): $v$ 3371.9, 2915.9, 2850.6, 1597.3, $1497.4 \mathrm{~cm}^{-1} ;{ }^{\mathbf{1}} \mathbf{H}$ NMR (500 MHz, $\left.\mathrm{CDCl}_{3}\right): \delta 7.28-7.22(\mathrm{~m}, 2 \mathrm{H}), 6.97-6.91(\mathrm{~m}, 2 \mathrm{H}), 6.82(\mathrm{td}, J=7.3,1.1 \mathrm{~Hz}, 1 \mathrm{H}), 5.24$ (ddt, $J=$ 7.7, 6.3, $1.5 \mathrm{~Hz}, 1 \mathrm{H}), 3.51(\mathrm{~d}, J=5.9 \mathrm{~Hz}, 2 \mathrm{H}), 3.26-3.10(\mathrm{~m}, 4 \mathrm{H}), 2.14(\mathrm{~d}, J=7.7 \mathrm{~Hz}, 2 \mathrm{H}), 1.74$ $(\mathrm{s}, 3 \mathrm{H}), 1.71-1.58(\mathrm{~m}, 4 \mathrm{H}), 1.67(\mathrm{~s}, 3 \mathrm{H}), 1.38(\mathrm{t}, J=6.0 \mathrm{~Hz}, 1 \mathrm{H}) ;{ }^{13} \mathbf{C} \mathbf{N M R}\left(125 \mathrm{MHz}, \mathrm{CDCl}_{3}\right)$ : $\delta$ 151.9, 134.4 129.2, 119.8, 119.4, 116.3, 68.2, 45.5, 36.7, 33.4, 31.9, 26.3, 18.1; HRMS $\left(\mathrm{ESI}^{+}\right)$: $[\mathrm{M}+\mathrm{H}]^{+}$calculated for $\left[\mathrm{C}_{17} \mathrm{H}_{26} \mathrm{NO}\right]^{+}$required $260.2009 \mathrm{~m} / \mathrm{z}$, found $260.2006 \mathrm{~m} / \mathrm{z}$.

5-Methyl-1-(quinolin-4-yl)hex-4-en-1-ol (SI, S33). To a solution of 4-quinolinecarboxyaldehyde<smiles>CC(C)=CCCC(O)c1ccnc2ccccc12</smiles>
$(0.512 \mathrm{~g}, 3.26 \mathrm{mmol})$ in THF $(8.3 \mathrm{~mL})$ at $0{ }^{\circ} \mathrm{C}$ was added a solution of homoprenyl magnesium bromide $(7.60 \mathrm{~mL}, 3.82 \mathrm{mmol})$ in THF $(1.0 \mathrm{M})$ dropwise via syringe and the resulting solution was stirred at $\mathrm{rt}$ for $5 \mathrm{~h}$. The reaction was quenched with sat. aq. $\mathrm{NH}_{4} \mathrm{Cl}(50 \mathrm{~mL})$ and extracted with $\mathrm{Et}_{2} \mathrm{O}$ (3x). The combined organic extracts were washed with $\mathrm{H}_{2} \mathrm{O}$ and brine, dried over $\mathrm{MgSO}_{4}$, filtered, and concentrated under reduced pressure to give crude $\mathbf{S 3 3}(0.608 \mathrm{~g})$ as a yellow oil. The crude residue was purified by chromatography on $\mathrm{SiO}_{2}$ (50\% EtOAc in hexanes) to give $\mathbf{S 3 3}$ (0.170 g, $0.704 \mathrm{mmol}, 22 \%$ ) as a clear, pale yellow oil.

IR (ATR): v 3204.7, 2963.7, 2917.8, 2855.7, 1586.3, $759.8 \mathrm{~cm}^{-1} ;{ }^{1} \mathbf{H}$ NMR (500 MHz, $\left.\mathrm{CDCl}_{3}\right): \delta$ $8.90(\mathrm{~d}, J=4.5 \mathrm{~Hz}, 1 \mathrm{H}), 8.14(\mathrm{~d}, J=8.4 \mathrm{~Hz}, 1 \mathrm{H}), 8.00$ (d, $J=8.2 \mathrm{~Hz}, 1 \mathrm{H}), 7.71$ (ddd, $J=8.3$, $6.9,1.4 \mathrm{~Hz}, 1 \mathrm{H}), 7.58$ (d, $J=4.5 \mathrm{~Hz}, 1 \mathrm{H}), 7.56$ (ddd, $J=8.2,6.9,1.2 \mathrm{~Hz}, 1 \mathrm{H}), 5.49$ (dd, $J=8.6$, $3.7 \mathrm{~Hz}, 1 \mathrm{H}), 5.24-5.19(\mathrm{~m}, 1 \mathrm{H}), 2.34-2.17(\mathrm{~m}, 2 \mathrm{H}), 2.02-1.82(\mathrm{~m}, 3 \mathrm{H}), 1.73(\mathrm{~d}, J=0.7 \mathrm{~Hz}, 3$ $\mathrm{H}), 1.64(\mathrm{~s}, 3 \mathrm{H}) ;{ }^{13} \mathbf{C}$ NMR $\left(125 \mathrm{MHz}, \mathrm{CDCl}_{3}\right): \delta 150.5,150.5,148.4,133.4,130.5,129.2,126.6$, 125.6, 123.4, 123.1, 117.4, 70.0, 38.5, 25.9, 24.8, 18.0; HRMS $\left(\mathrm{ESI}^{+}\right):[\mathrm{M}+\mathrm{H}]^{+}$calculated for $\left[\mathrm{C}_{16} \mathrm{H}_{20} \mathrm{NO}\right]^{+}$required $242.1539 \mathrm{~m} / \mathrm{z}$, found $242.1534 \mathrm{~m} / \mathrm{z}$. 
4-(4-Methylpent-3-en-1-yl)-1-tosylpiperidin-4-ol (SI, S34). To a roundbottom flask with a<smiles>CC(C)=CCC1(O)CCNCC1</smiles>
reflux condenser was added $\mathrm{Mg}^{0}$ turnings $(0.259 \mathrm{~g}, 10.7 \mathrm{mmol})$ and the flask was flame dried under vacuum and cooled to $\mathrm{rt}$ under $\mathrm{N}_{2}$. THF $(5 \mathrm{~mL})$ was added followed by dibromoethane $(0.090 \mathrm{~mL}, 0.49 \mathrm{mmol})$ and a solution of homoprenyl bromide $(1.31$ $\mathrm{mL}, 9.8 \mathrm{mmol})$ in THF $(15 \mathrm{~mL})$ dropwise via syringe. The mixture was stirred at reflux for $1 \mathrm{~h} .1$ - $p$-Toluenesulfonyl-4-piperidone (1.24 g, $4.9 \mathrm{mmol})$ in THF (8 mL) was added dropwise via syringe and the resulting solution was stirred at $\mathrm{rt}$ for $30 \mathrm{~min}$. The reaction mixture was quenched with sat. aq. $\mathrm{NH}_{4} \mathrm{Cl}(50 \mathrm{~mL})$ and extracted with $\mathrm{Et}_{2} \mathrm{O}(3 \mathrm{x} 50 \mathrm{~mL})$. The combined organic extracts were washed with $\mathrm{H}_{2} \mathrm{O}(2 \mathrm{x})$ and brine $(2 \mathrm{x})$, dried over $\mathrm{Na}_{2} \mathrm{SO}_{4}$, filtered, and concentrated under reduced pressure to give crude S34 (1.66 g) as a yellow oil. The crude residue was purified by chromatography on $\mathrm{SiO}_{2}(30 \%$ EtOAc in hexanes) to give $\mathbf{S 3 4}(0.197 \mathrm{~g}$, $0.58 \mathrm{mmol}, 12 \%$ ) as a white, crystalline solid.

Mp 116-118 ${ }^{\circ} \mathrm{C}$; IR (ATR): v 3509.0, 2919.7, 2864.1, 1596.1, $1159.8 \mathrm{~cm}^{-1}$; ${ }^{\mathbf{1}} \mathbf{H}$ NMR (500 MHz, $\left.\mathrm{CDCl}_{3}\right): \delta 7.67-7.61(\mathrm{~m}, 2 \mathrm{H}), 7.31(\mathrm{~d}, J=8.0 \mathrm{~Hz}, 2 \mathrm{H}), 5.10(\mathrm{tt}, J=7.1,1.5 \mathrm{~Hz}, 1 \mathrm{H}), 3.55(\mathrm{dt}, J$ $=11.2,2.5 \mathrm{~Hz}, 2 \mathrm{H}), 2.63(\mathrm{td}, J=11.9,2.9 \mathrm{~Hz}, 2 \mathrm{H}), 2.43(\mathrm{~s}, 3 \mathrm{H}), 2.05(\mathrm{q}, J=7.6 \mathrm{~Hz}, 2 \mathrm{H}), 1.76-$ $1.63(\mathrm{~m}, 5 \mathrm{H}), 1.52-1.45(\mathrm{~m}, 2 \mathrm{H}), 1.10(\mathrm{~s}, 1 \mathrm{H}) ;{ }^{13} \mathbf{C ~ N M R}\left(125 \mathrm{MHz}, \mathrm{CDCl}_{3}\right): \delta 143.5,133.4$, 132.8, 129.8, 127.8, 124.0, 69.2, 42.8, 42.3, 36.4, 25.8, 21.8, 21.7, 17.9; HRMS $\left(\mathrm{ESI}^{+}\right):[\mathrm{M}+\mathrm{H}]^{+}$ calculated for $\left[\mathrm{C}_{18} \mathrm{H}_{28} \mathrm{NO}_{3} \mathrm{~S}\right]^{+}$required $338.1784 \mathrm{~m} / \mathrm{z}$, found $338.1779 \mathrm{~m} / \mathrm{z}$.

1-(tert-Butyl)-3-methyl-3-(3-methylbut-2-en-1-yl)azetidine-1,3-dicarboxylate (SI, S35). A $\mathrm{CO}_{2} \mathrm{Me} \quad$ solution of $i-\mathrm{Pr}_{2} \mathrm{NH}(3.40 \mathrm{~mL}, 24.00 \mathrm{mmol})$ in $\mathrm{THF}(40 \mathrm{~mL})$ at $0{ }^{\circ} \mathrm{C}$ was treated dropwise via syringe with a solution of $n$-BuLi $(9.75 \mathrm{~mL}, 24.0 \mathrm{mmol})$ in hexanes $(2.46 \mathrm{M})$ and the resulting solution was stirred at $0{ }^{\circ} \mathrm{C}$ for $30 \mathrm{~min}$. Methyl 1-bocazetidine-3-carboxylate $(4.00 \mathrm{~mL}, 20.00 \mathrm{mmol})$ was added dropwise via syringe and the resulting solution was stirred at $0{ }^{\circ} \mathrm{C}$ for $30 \mathrm{~min}$. Prenyl bromide $(2.77 \mathrm{~mL}, 24.0 \mathrm{mmol})$ was added dropwise via syringe and the resulting solution was stirred at $\mathrm{rt}$ for $18 \mathrm{~h}$. The reaction mixture was quenched with sat. aq. $\mathrm{NH}_{4} \mathrm{Cl}(100 \mathrm{~mL})$ and extracted with $\mathrm{Et}_{2} \mathrm{O}(3 \mathrm{x} 50 \mathrm{~mL})$. The combined organic extracts were washed with $\mathrm{H}_{2} \mathrm{O}(2 \mathrm{x})$ and brine $(2 \mathrm{x})$, dried over $\mathrm{MgSO}_{4}$, filtered, and concentrated under reduced pressure to give crude S35 (5.32 g) as an orange oil. The crude residue was purified by chromatography on $\mathrm{SiO}_{2}\left(20 \% \mathrm{Et}_{2} \mathrm{O}\right.$ in hexanes) to give $\mathbf{S 3 5}(1.50 \mathrm{~g})$ as a yellow oil which was used without further purification.

Methyl-3-(3-methylbut-2-en-1-yl)azetidine-3-carboxylate (SI, S36). A solution of S35 (1.50 g) $\mathrm{CO}_{2} \mathrm{Me} \quad$ and trifluoroacetic acid $(6.15 \mathrm{~mL}, 80.3 \mathrm{mmol})$ in $\mathrm{CH}_{2} \mathrm{Cl}_{2}(12 \mathrm{~mL})$ was stirred at $\mathrm{rt}$ for $2 \mathrm{~h}$. The reaction mixture was diluted with $\mathrm{CH}_{2} \mathrm{Cl}_{2}(50 \mathrm{~mL})$ and $6 \mathrm{M}$ aq. $\mathrm{NaOH}$ was added to $\mathrm{pH} 11$. The layers were separated and the organic phase was washed with $6 \mathrm{M}$ aq. $\mathrm{NaOH}(2 \mathrm{x})$ and $\mathrm{H}_{2} \mathrm{O}(2 \mathrm{x})$, dried over $\mathrm{Na}_{2} \mathrm{SO}_{4}$, filtered, and concentrated under reduced pressure to give crude $\mathbf{S 3 6}$ (1.09 $\mathrm{g}$ ) as a yellow oil which was used without further purification.

Methyl 3-(3-methylbut-2-en-1-yl)-1-tosylazetidine-3-carboxylate (SI, S37). To a solution of

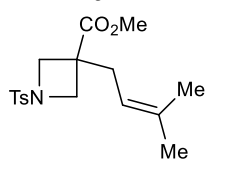
S36 (1.09 g) and $\mathrm{Et}_{3} \mathrm{~N}(1.25 \mathrm{~mL}, 8.92 \mathrm{mmol})$ in $\mathrm{CH}_{2} \mathrm{Cl}_{2}(25 \mathrm{~mL})$ at $0{ }^{\circ} \mathrm{C}$ was added $\mathrm{TsCl}(1.26 \mathrm{~g}, 6.61 \mathrm{mmol})$ in a single portion and the resulting solution was stirred at $\mathrm{rt}$ for $18 \mathrm{~h}$. The reaction mixture was concentrated under reduced pressure, taken up in $\mathrm{Et}_{2} \mathrm{O}$, eluted through a thin pad of $\mathrm{SiO}_{2}$, and concentrated under reduced 
pressure to give $\mathbf{S 3 7}$ ( $0.965 \mathrm{~g}$ ) as a yellow oil. The crude residue was purified by chromatography on $\mathrm{SiO}_{2}\left(10-30 \% \mathrm{Et}_{2} \mathrm{O}\right.$ in hexanes) to give $\mathbf{S 3 7}(0.897 \mathrm{~g})$ as a yellow oil which was used without further purification.

(3-(3-Methylbut-2-en-1-yl)-1-tosylazetidin-3-yl)methanol (SI, S38). To a suspension of $\mathrm{LiAlH}_{4}$

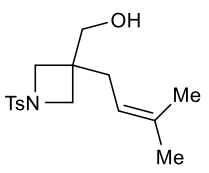
$(0.207 \mathrm{~g}, 5.45 \mathrm{mmol})$ in $\mathrm{Et}_{2} \mathrm{O}(5 \mathrm{~mL})$ at $0{ }^{\circ} \mathrm{C}$ was added a solution of $\mathbf{S 3 7}(0.897 \mathrm{~g})$ in $\mathrm{Et}_{2} \mathrm{O}(4 \mathrm{~mL})$ dropwise via syringe and the resulting solution was stirred at $\mathrm{rt}$ for $1.5 \mathrm{~h}$. The mixture was cooled to $0{ }^{\circ} \mathrm{C}$, quenched with $3 \mathrm{M}$ aq. $\mathrm{NaOH}(5 \mathrm{~mL})$, dried over $\mathrm{Na}_{2} \mathrm{SO}_{4}$, filtered, and concentrated under reduced pressure to give crude $\mathbf{S 3 8}$ $(0.638 \mathrm{~g})$ as a yellow oil. The crude oil was purified by chromatography on $\mathrm{SiO}_{2}(30 \% \mathrm{EtOAc}$ in hexanes) to give $\mathbf{S 3 8}(0.577 \mathrm{~g}, 1.86 \mathrm{mmol}, 9 \%$ over 4 steps $)$ as a white solid.

Mp 82-84 ${ }^{\circ} \mathrm{C}$; IR (ATR): v 3521.8, 2922.1, 2876.6, 1597.3, 1337.2, $1156.1 \mathrm{~cm}^{-1} ;{ }^{1} \mathbf{H}$ NMR $(500$ $\left.\mathrm{MHz} \mathrm{CDCl}_{3}\right): \delta 7.76-7.71(\mathrm{~m}, 2 \mathrm{H}), 7.41-7.34(\mathrm{~m}, 2 \mathrm{H}), 4.90-4.86(\mathrm{~m}, 1 \mathrm{H}), 3.56(\mathrm{~d}, J=8.0 \mathrm{~Hz}$, $2 \mathrm{H}), 3.51-3.45(\mathrm{~m}, 4 \mathrm{H}), 2.46(\mathrm{~s}, 3 \mathrm{H}), 2.12(\mathrm{~d}, J=7.5 \mathrm{~Hz}, 2 \mathrm{H}), 1.62(\mathrm{~s}, 3 \mathrm{H}), 1.53(\mathrm{~s}, 3 \mathrm{H}) ;{ }^{13} \mathrm{C}$ NMR $\left(125 \mathrm{MHz}, \mathrm{CDCl}_{3}\right): \delta 144.1,135.7,131.9,129.8,128.5,118.0,66.3,66.3,56.6,38.5,32.5$, 26.0, 21.7, 18.1; HRMS $\left(\mathrm{ESI}^{+}\right):[\mathrm{M}+\mathrm{H}]^{+}$calculated for $\left[\mathrm{C}_{16} \mathrm{H}_{23} \mathrm{NO}_{3} \mathrm{SNa}\right]^{+}$required $332.1291 \mathrm{~m} / \mathrm{z}$, found $332.1289 \mathrm{~m} / \mathrm{z}$.

2-(3-Methylbut-2-en-1-yl)-1,2,3,4-tetrahydronaphthalen-1-ol (SI, S39). Synthesized according Me $\quad \mathrm{OH}^{\mathrm{H}} \quad$ to the method of Park and coworkers. ${ }^{6}$ All spectral data were in agreement with previously reported values.

(E)-1-Bromo-2-methylbut-2-ene (SI, S40). Synthesized according to the method of Alexanian ${ }^{\mathrm{Br}} \quad$ and coworkers. ${ }^{7}$ All spectral data were in agreement with previously reported values.

(E)-2,2,4-Trimethylhex-4-enenitrile (SI, S41). A solution of $i$ - $\operatorname{Pr}_{2} \mathrm{NH}(0.495 \mathrm{~mL}, 3.51$ Me $\mathrm{Me} \quad \mathrm{mmol})$ in THF $(5 \mathrm{~mL})$ at $0{ }^{\circ} \mathrm{C}$ was added $n$-BuLi $(1.40 \mathrm{~mL}, 3.51 \mathrm{mmol})$ in hexanes (2.51 M) dropwise via syringe and the resulting solution was stirred $0{ }^{\circ} \mathrm{C}$ for $10 \mathrm{~min}$. Isobutyronitrile $(0.315 \mathrm{~mL}, 3.51 \mathrm{mmol})$ was added dropwise via syringe and the resulting solution was stirred at $0{ }^{\circ} \mathrm{C}$ for $10 \mathrm{~min}$. A solution of $\mathbf{S 4 0}(0.523 \mathrm{~g}, 3.51 \mathrm{mmol})$ in THF ( $2 \mathrm{~mL})$ was added dropwise via syringe and the resulting solution was stirred at $\mathrm{rt}$ for $2 \mathrm{~h}$. The reaction mixture was quenched with sat. aq. $\mathrm{NH}_{4} \mathrm{Cl}(20 \mathrm{~mL})$ and extracted with $\mathrm{Et}_{2} \mathrm{O}(3 \times 20$ $\mathrm{mL})$. The combined organic extracts were washed with $\mathrm{H}_{2} \mathrm{O}(2 \mathrm{x})$ and brine $(2 \mathrm{x})$, dried over $\mathrm{MgSO}_{4}$, filtered, and concentrated under reduced pressure to give crude $\mathbf{S 4 1}(0.329 \mathrm{~g})$ as an orange oil which was used without further purification.

(E)-2,2,4-Trimethylhex-4-en-1-amine (SI, S42). To a suspension of $\mathrm{LiAlH}_{4}(0.182 \mathrm{~g}, 4.80 \mathrm{mmol})$<smiles>CC=C(C)C[C@](C)(N)CN</smiles>
in $\mathrm{Et}_{2} \mathrm{O}(5 \mathrm{~mL})$ at $0{ }^{\circ} \mathrm{C}$ was added a solution of crude $\mathbf{S 4 1}(0.329 \mathrm{~g})$ in $\mathrm{Et}_{2} \mathrm{O}(3 \mathrm{~mL})$ dropwise via syringe and the resulting solution was stirred at $\mathrm{rt}$ for $1 \mathrm{~h}$. The reaction mixture was cooled to $0{ }^{\circ} \mathrm{C}$ and quenched by dropwise addition of $3 \mathrm{M}$ aq. $\mathrm{NaOH}(5$ $\mathrm{mL})$. The reaction mixture was stirred at $0{ }^{\circ} \mathrm{C}$ for $10 \mathrm{~min}$, diluted with $\mathrm{Et}_{2} \mathrm{O}(50 \mathrm{~mL})$, 
dried over $\mathrm{Na}_{2} \mathrm{SO}_{4}$, filtered, and concentrated under reduced pressure to give crude $\mathbf{S 4 2}(0.455 \mathrm{~g})$ as a green-yellow oil.

(E)-4-Methyl- $N$-(2,2,4-trimethylhex-4-en-1-yl)benzenesulfonamide (SI, S43). To a solution of $\overbrace{\mathrm{Me}}^{\mathrm{Me}}$ crude $\mathbf{S 4 2}(0.455 \mathrm{~g})$ and $\mathrm{Et}_{3} \mathrm{~N}(0.500 \mathrm{~mL}, 3.60 \mathrm{mmol})$ in $\mathrm{CH}_{2} \mathrm{Cl}_{2}(8 \mathrm{~mL})$ at $0{ }^{\circ} \mathrm{C}$ was added $\mathrm{TsCl}(0.501 \mathrm{~g}, 2.63 \mathrm{mmol})$ in a single portion and the resulting solution was stirred at $\mathrm{rt}$ for $1 \mathrm{~h}$. The reaction mixture was concentrated under reduced pressure, taken up in $\mathrm{Et}_{2} \mathrm{O}$, eluted through a thin pad of $\mathrm{SiO}_{2}$, and concentrated under reduced pressure to give crude $\mathbf{S 4 3}(0.676 \mathrm{~g})$ as a yellow oil. The crude residue was purified by chromatography on $\mathrm{SiO}_{2}$ (10\% EtOAc in hexanes) to give $\mathbf{S 4 3}$ (0.379 g, $1.28 \mathrm{mmol}$, $37 \%$ over 3 steps) as a yellow oil.

IR (ATR): v 3284.9, 2963.4, 2918.7, $1324.2 \mathrm{~cm}^{-1} ;{ }^{\mathbf{1}} \mathbf{H} \mathbf{~ N M R}\left(500 \mathrm{MHz}, \mathrm{CDCl}_{3}\right): \delta 7.74(\mathrm{~d}, J=8.3$ $\mathrm{Hz}, 2 \mathrm{H}), 7.30(\mathrm{~d}, J=8.0 \mathrm{~Hz}, 2 \mathrm{H}), 5.12(\mathrm{q}, J=6.6 \mathrm{~Hz}, 1 \mathrm{H}), 4.57(\mathrm{t}, J=6.7 \mathrm{~Hz}, 1 \mathrm{H}), 2.67(\mathrm{~d}, J=$ $6.8 \mathrm{~Hz}, 2 \mathrm{H}), 2.43(\mathrm{~s}, 3 \mathrm{H}), 1.89$ (s, $2 \mathrm{H}), 1.59$ (s, $3 \mathrm{H}), 1.54(\mathrm{~d}, J=6.7 \mathrm{~Hz}, 3 \mathrm{H}), 0.85(\mathrm{~s}, 6 \mathrm{H}) ;{ }^{13} \mathrm{C}$ NMR $\left(125 \mathrm{MHz}, \mathrm{CDCl}_{3}\right): \delta 143.4,137.1,132.8,129.8,127.2,123.5,53.6,49.5,35.1,25.7,21.7$, 18.7, 13.7; HRMS $\left(\mathrm{ESI}^{+}\right):[\mathrm{M}+\mathrm{H}]^{+}$calculated for $\left[\mathrm{C}_{16} \mathrm{H}_{26} \mathrm{NO}_{2} \mathrm{~S}\right]^{+}$required $296.1679 \mathrm{~m} / \mathrm{z}$, found $296.1689 \mathrm{~m} / \mathrm{z}$.

Ethyl-4-(tetrahydro-4H-pyran-4-ylidene)butanoate (SI, S44). Synthesized according to the method of Shenvi and coworkers. ${ }^{8}$ All spectral data were in agreement with
previously reported values.

4-(Tetrahydro-4H-pyran-4-ylidene)butan-1-ol (SI, S45). To a suspension of $\mathrm{LiAlH}_{4}(0.271 \mathrm{~g}$, он $7.14 \mathrm{mmol})$ in $\mathrm{Et}_{2} \mathrm{O}(8 \mathrm{~mL})$ at $0{ }^{\circ} \mathrm{C}$ was added a solution of $\mathbf{S 4 4}(0.703 \mathrm{~g}, 3.55$ $\mathrm{mmol})$ in $\mathrm{Et}_{2} \mathrm{O}(4 \mathrm{~mL})$ dropwise via syringe and the resulting solution was stirred at $\mathrm{rt}$ for $1 \mathrm{~h}$. The reaction mixture was cooled to $0{ }^{\circ} \mathrm{C}$ and quenched with $3 \mathrm{M}$ aq. $\mathrm{NaOH}(7 \mathrm{~mL})$. The mixture was stirred for $10 \mathrm{~min}$, dried over $\mathrm{Na}_{2} \mathrm{SO}_{4}$, filtered, and concentrated under reduced pressure to give crude $\mathbf{S 4 5}(0.830 \mathrm{~g})$ as a clear, colorless oil which was used without further purification.

4-(Tetrahydro-4H-pyran-4-ylidene)butyl methanesulfonate (SI, S46). A solution of crude S45 oms $(0.830 \mathrm{~g})$ and $\mathrm{Et}_{3} \mathrm{~N}(0.590 \mathrm{~mL}, 4.26 \mathrm{mmol})$ in $\mathrm{CH}_{2} \mathrm{Cl}_{2}(7.1 \mathrm{~mL})$ at $0{ }^{\circ} \mathrm{C}$ was treated dropwise via syringe with $\mathrm{MsCl}(0.330 \mathrm{~mL}, 4.26 \mathrm{mmol})$ and the resulting solution was stirred at $\mathrm{rt}$ for $2 \mathrm{~h}$. The reaction mixture was quenched by dropwise addition of sat. aq. $\mathrm{NaHCO}_{3}(6 \mathrm{~mL})$ and diluted with $\mathrm{H}_{2} \mathrm{O}(50 \mathrm{~mL})$. The mixture was extracted with $\mathrm{CH}_{2} \mathrm{Cl}_{2}(3 \mathrm{x})$ and the combined organic extracts were dried over $\mathrm{MgSO}_{4}$, filtered, and concentrated under reduced pressure to give crude $\mathbf{S 4 6}(0.738 \mathrm{~g})$ as a clear, colorless oil which was used without further purification.

4-(4-Azidobutylidene)tetrahydro-2H-pyran (SI, S47). A solution of crude S46 (0.738 g) and $\mathrm{NaN}_{3}(0.625 \mathrm{~g}, 9.61 \mathrm{mmol})$ in $\mathrm{DMF}(11 \mathrm{~mL})$ was stirred at $60{ }^{\circ} \mathrm{C}$ for $2 \mathrm{~h}$. The
reaction mixture was cooled to rt, diluted with $\mathrm{H}_{2} \mathrm{O}(100 \mathrm{~mL})$, and extracted with
$\mathrm{CH}_{2} \mathrm{Cl}_{2}(3 \times 50 \mathrm{~mL})$. The combined organic extracts were washed with $\mathrm{H}_{2} \mathrm{O}(3 \mathrm{x})$ and brine (1x), dried over $\mathrm{MgSO}_{4}$, filtered, and concentrated under reduced pressure to give a pale 
yellow oil. The crude oil was eluted through a thin pad of $\mathrm{SiO}_{2}$ with $\mathrm{Et}_{2} \mathrm{O}$ and concentrated under reduced pressure to give crude $\mathbf{S 4 7}(0.522 \mathrm{~g})$ as a milky white oil which was used without further purification.

4-(Tetrahydro-4H-pyran-4-ylidene)butan-1-amine (SI, S48). To a suspension of $\mathrm{LiAlH}_{4}(0.219$ $\left.\mathrm{NH}_{2} \quad \mathrm{~g}, 5.76 \mathrm{mmol}\right)$ in $\mathrm{Et}_{2} \mathrm{O}(6.6 \mathrm{~mL})$ at $0{ }^{\circ} \mathrm{C}$ was added a solution of crude $\mathbf{S 4 7}$ $(0.522 \mathrm{~g})$ in $\mathrm{Et}_{2} \mathrm{O}(3 \mathrm{~mL})$ dropwise via syringe and the resulting solution was stirred at $\mathrm{rt}$ for $2 \mathrm{~h}$. The reaction mixture was cooled to $0{ }^{\circ} \mathrm{C}$, quenched by dropwise addition of $3 \mathrm{M}$ aq. $\mathrm{NaOH}(6 \mathrm{~mL})$, and stirred for $15 \mathrm{~min}$. The mixture was dried over $\mathrm{Na}_{2} \mathrm{SO}_{4}$, filtered, and concentrated under reduced pressure to give crude $\mathbf{S 4 8}(0.380 \mathrm{~g})$ as a clear, colorless oil which was used without further purification.

4-Methyl- $\boldsymbol{N}$-(4-(tetrahydro-4H-pyran-4-ylidene)butyl)benzenesulfonamide (SI, S49). To a ${ }^{\mathrm{NHTs}}$ solution of crude $\mathbf{S 4 8}(0.380 \mathrm{~g})$ and $\mathrm{Et}_{3} \mathrm{~N}(0.510 \mathrm{~g}, 3.67 \mathrm{mmol})$ in $\mathrm{CH}_{2} \mathrm{Cl}_{2}(12$ $\mathrm{mL})$ was added $\mathrm{TsCl}(0.511 \mathrm{~g}, 2.68 \mathrm{mmol})$ in a single portion and the resulting solution was stirred at $\mathrm{rt}$ for $16 \mathrm{~h}$. The reaction mixture was concentrated under reduced pressure, taken up in $\mathrm{Et}_{2} \mathrm{O}$, eluted through a thin pad of $\mathrm{SiO}_{2}$, and concentrated under reduced pressure to give crude $\mathbf{S 4 9}(0.735 \mathrm{~g})$ as a clear, colorless oil. The crude residue was purified by chromatography on $\mathrm{SiO}_{2}$ (20\% EtOAc in hexanes) to give $\mathbf{S 4 9}$ (0.577 g, $1.86 \mathrm{mmol}$, $53 \%$ over 5 steps) as a clear, colorless oil.

IR (ATR): $v$ 3276.1, 2954.5, 2848.6, $1598.2,1158.4 \mathrm{~cm}^{-1} ;{ }^{1} \mathbf{H}$ NMR $\left(500 \mathrm{MHz}, \mathrm{CDCl}_{3}\right): \delta 7.78-$ $7.71(\mathrm{~m}, 2 \mathrm{H}), 7.34-7.29(\mathrm{~m}, 2 \mathrm{H}), 5.12-5.03(\mathrm{~m}, 1 \mathrm{H}), 4.37(\mathrm{t}, J=6.3 \mathrm{~Hz}, 1 \mathrm{H}), 3.64(\mathrm{t}, J=5.5$ $\mathrm{Hz}, 2 \mathrm{H}), 3.60$ (t, $J=5.4 \mathrm{~Hz}, 2 \mathrm{H}), 2.94(\mathrm{q}, J=6.8 \mathrm{~Hz}, 2 \mathrm{H}), 2.43(\mathrm{~s}, 3 \mathrm{H}), 2.21-2.18$ (m, $2 \mathrm{H}), 2.0$ $(\mathrm{q}, J=7.3 \mathrm{~Hz}, 2 \mathrm{H}), 1.51(\mathrm{p}, J=7.1 \mathrm{~Hz}, 2 \mathrm{H}) ;{ }^{13} \mathbf{C ~ N M R}\left(125 \mathrm{MHz}, \mathrm{CDCl}_{3}\right): \delta 143.6,137.1,135.8$, 129.9, 127.2, 121.7, 69.7, 68.8, 43.0, 37.0, 30.0, 29.8, 24.1, 21.7; HRMS $\left(\mathrm{ESI}^{+}\right):[\mathrm{M}+\mathrm{H}]^{+}$ calculated for $\left[\mathrm{C}_{16} \mathrm{H}_{23} \mathrm{NO}_{3} \mathrm{SNa}\right]^{+}$required $332.1291 \mathrm{~m} / \mathrm{z}$, found $332.1286 \mathrm{~m} / \mathrm{z}$.

(E)-5-Phenylhex-4-enenitrile (SI, S50). Synthesized according to the method of Knowles and coworkers. ${ }^{9}$ All spectral data were in agreement with previously reported values.

(E)-5-Phenylhex-4-en-1-amine (SI, S51). To a suspension of $\mathrm{LiAlH}_{4}(0.662 \mathrm{~g}, 17.4 \mathrm{mmol})$ in $\mathrm{Et}_{2} \mathrm{O}(35 \mathrm{~mL})$ at $0{ }^{\circ} \mathrm{C}$ was added a solution of $\mathbf{S 5 0}(1.489 \mathrm{~g}, 8.70 \mathrm{mmol})$ in
$\mathrm{Et}_{2} \mathrm{O}(9 \mathrm{~mL})$ dropwise via syringe and the resulting solution was stirred at $\mathrm{rt}$
for $1 \mathrm{~h}$. The reaction mixture was cooled to $0{ }^{\circ} \mathrm{C}$, quenched by dropwise addition of $3 \mathrm{M}$ aq. $\mathrm{NaOH}(10 \mathrm{~mL})$, and stirred for $15 \mathrm{~min}$. The resulting mixture was dried over $\mathrm{Na}_{2} \mathrm{SO}_{4}$, filtered, and concentrated under reduced pressure to give crude S51 (1.45 g) as a yellowgreen oil which was used without further purification.

(E)-4-Methyl- $\boldsymbol{N}$-(5-phenylhex-4-en-1-yl)benzenesulfonamide (SI, S52). To a solution of crude

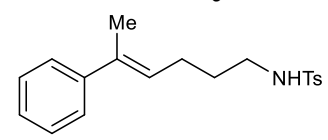
S51 (1.45 g) and $\mathrm{Et}_{3} \mathrm{~N}(1.73 \mathrm{~mL}, 12.4 \mathrm{mmol})$ in $\mathrm{CH}_{2} \mathrm{Cl}_{2}(28 \mathrm{~mL})$ at $0{ }^{\circ} \mathrm{C}$ was added $\mathrm{TsCl}(1.73 \mathrm{~g}, 9.07 \mathrm{mmol})$ in a single portion and the resulting solution was stirred at $\mathrm{rt}$ for $1 \mathrm{~h}$. The reaction mixture was concentrated under reduced pressure, taken up in $\mathrm{Et}_{2} \mathrm{O}$, eluted through a thin pad of $\mathrm{SiO}_{2}$ with $\mathrm{Et}_{2} \mathrm{O}$, and concentrated under 
reduced pressure to give crude S52 $(2.71 \mathrm{~g})$ as a yellow oil. The crude oil was purified by chromatography on $\mathrm{SiO}_{2}$ (10-30\% EtOAc in hexanes) to give $\mathbf{S 5 2}$ (2.09 g, $6.34 \mathrm{mmol}$, 73\% over 2 steps) as a clear, colorless oil.

IR (ATR): $v$ 3279.8, 2930.3, 2865.9, 1597.5, $1154.1 \mathrm{~cm}^{-1} ;{ }^{1} \mathbf{H} \mathbf{N M R}\left(500 \mathrm{MHz}, \mathrm{CDCl}_{3}\right): \delta 7.67$ $(\mathrm{d}, J=8.2 \mathrm{~Hz}, 2 \mathrm{H}), 7.53(\mathrm{t}, J=5.8 \mathrm{~Hz}, 1 \mathrm{H}), 7.38(\mathrm{~d}, J=8.4 \mathrm{~Hz}, 2 \mathrm{H}), 7.35-7.26(\mathrm{~m}, 4 \mathrm{H}), 7.22-$ $7.18(\mathrm{~m}, 1 \mathrm{H}), 5.67(\mathrm{td}, J=7.3,1.4 \mathrm{~Hz}, 1 \mathrm{H}), 2.76(\mathrm{q}, J=6.9 \mathrm{~Hz}, 2 \mathrm{H}), 2.37(\mathrm{~s}, 3 \mathrm{H}), 2.12(\mathrm{q}, J=$ $7.4 \mathrm{~Hz}, 2 \mathrm{H}), 1.92$ (s, $3 \mathrm{H}), 1.50$ (p, $J=7.2 \mathrm{~Hz}, 2 \mathrm{H}) ;{ }^{13} \mathbf{C}$ NMR (125 MHz, $\left.\mathrm{CDCl}_{3}\right): \delta$ 143.4, 134.0, 138.1, 135.2, 130.1, 128.7, 127.4, 127.1, 127.0, 125.7, 42.6, 29.4, 25.8, 21.4, 15.9; HRMS (ESI ${ }^{+}$): $[\mathrm{M}+\mathrm{H}]^{+}$calculated for $\left[\mathrm{C}_{19} \mathrm{H}_{24} \mathrm{NO}_{2} \mathrm{~S}\right]^{+}$required $330.1522 \mathrm{~m} / \mathrm{z}$, found $330.1517 \mathrm{~m} / \mathrm{z}$.

1-Bromo-2,3-dimethylbut-2-ene (SI, S53). Synthesized according to the method of Zhang and<smiles>CC(C)=C(C)CBr</smiles>
coworkers. ${ }^{10}$ All spectral data were in agreement with previously reported values.

8-(2,3-Dimethylbut-2-en-1-yl)-1,4-dioxaspiro[4.5]decane-8-carbonitrile (SI, S54). A solution Me of $i-\mathrm{Pr}_{2} \mathrm{NH}(1.00 \mathrm{~mL}, 7.36 \mathrm{mmol})$ in $\mathrm{THF}(10 \mathrm{~mL})$ at $0{ }^{\circ} \mathrm{C}$ was treated dropwise via Me syringe with a solution of $n$ - BuLi $(3.00 \mathrm{~mL}, 7.36 \mathrm{mmol})$ in hexanes $(2.46 \mathrm{M})$ and the " $\mathrm{CN}$ resulting solution was stirred at $0{ }^{\circ} \mathrm{C}$ for $30 \mathrm{~min}$. A solution of 1,4dioxaspiro[4.5]decane-8-carbonitrile $(1.24 \mathrm{~g}, 7.42 \mathrm{mmol})$ in THF $(2 \mathrm{~mL})$ was added dropwise via syringe and the resulting solution was stirred at $0{ }^{\circ} \mathrm{C}$ for $30 \mathrm{~min}$. A ${ }^{\prime} j$ solution of $\mathbf{S 5 3}(1.00 \mathrm{~g}, 6.13 \mathrm{mmol})$ in THF $(2 \mathrm{~mL})$ was added dropwise via syringe and the solution was stirred at $\mathrm{rt}$ for $12 \mathrm{~h}$. The reaction mixture was quenched with sat. aq. $\mathrm{NH}_{4} \mathrm{Cl}$ $(100 \mathrm{~mL})$ and extracted with $\mathrm{Et}_{2} \mathrm{O}(3 \times 50 \mathrm{~mL})$. The combined organic extracts were washed with $\mathrm{H}_{2} \mathrm{O}(2 \mathrm{x})$ and brine $(2 \mathrm{x})$, dried over $\mathrm{MgSO}_{4}$, filtered, and concentrated under reduced pressure to give crude S54 (1.45 g) as a yellow oil which was used without further purification.

(8-(2,3-Dimethylbut-2-en-1-yl)-1,4-dioxaspiro[4.5]decan-8-yl)methanamine (SI, S55). To a suspension of $\mathrm{LiAlH}_{4}(0.439 \mathrm{~g}, 11.6 \mathrm{mmol})$ in $\mathrm{Et}_{2} \mathrm{O}(13 \mathrm{~mL})$ at $0{ }^{\circ} \mathrm{C}$ was added a solution of crude $\mathrm{S54}$ (1.45 g) in $\mathrm{Et}_{2} \mathrm{O}(6.4 \mathrm{~mL})$ dropwise via syringe and the resulting solution was stirred at $\mathrm{rt}$ for $1 \mathrm{~h}$. The reaction mixture was cooled to $0{ }^{\circ} \mathrm{C}$, quenched by dropwise addition of $3 \mathrm{M}$ aq. $\mathrm{NaOH}(10 \mathrm{~mL})$, and stirred at $0{ }^{\circ} \mathrm{C}$ for 15 min. The mixture was dried over $\mathrm{Na}_{2} \mathrm{SO}_{4}$, filtered, and concentrated under reduced pressure to give crude $\mathbf{S 5 5}$ (1.42 g) as a clear, colorless oil which was used without further purification.

\section{$N$-((8-(2,3-Dimethylbut-2-en-1-yl)-1,4-dioxaspiro[4.5]decan-8-yl)methyl)-4-}

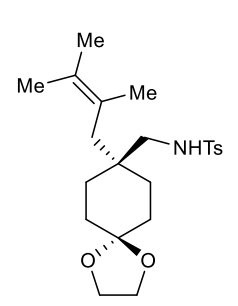
methylbenzenesulfonamide (SI, S56). To a solution of crude S55 (1.42 g) and $\mathrm{Et}_{3} \mathrm{~N}(1.20 \mathrm{~mL}, 8.60 \mathrm{mmol})$ in $\mathrm{CH}_{2} \mathrm{Cl}_{2}(29 \mathrm{~mL})$ at $0{ }^{\circ} \mathrm{C}$ was added $\mathrm{TsCl}(1.22 \mathrm{~g}$, $6.40 \mathrm{mmol}$ ) in a single portion and the resulting solution was stirred at $\mathrm{rt}$ for $3 \mathrm{~h}$. The reaction mixture was concentrated under reduced pressure, taken up in $\mathrm{Et}_{2} \mathrm{O}$, eluted through a thin pad of $\mathrm{SiO}_{2}$ with $\mathrm{Et}_{2} \mathrm{O}$, and concentrated under reduced pressure to give crude $\mathbf{S 5 6}$ (2.39 g) as a white, foaming solid. The crude foam was purified by chromatography on $\mathrm{SiO}_{2}(10-20 \%$ EtOAc in hexanes) to give $\mathbf{S 5 6}$ (1.00 $\mathrm{g}, 2.45 \mathrm{mmol}, 40 \%$ over 3 steps) as a white powder. 
Mp 117-120 ${ }^{\circ} \mathrm{C}$; IR (ATR): v 3280.5, 2932.4, 2870.3, 1598.8, 1327.1, $1160.2 \mathrm{~cm}^{-1}$; ${ }^{1} \mathbf{H}$ NMR $\left(500 \mathrm{MHz}, \mathrm{CDCl}_{3}\right): \delta 7.70(\mathrm{~d}, J=8.2 \mathrm{~Hz}, 2 \mathrm{H}), 7.31(\mathrm{~d}, J=8.0 \mathrm{~Hz}, 2 \mathrm{H}), 4.55(\mathrm{t}, J=6.8 \mathrm{~Hz}, 1 \mathrm{H})$, $3.91(\mathrm{~s}, 4 \mathrm{H}), 2.84(\mathrm{~d}, J=6.8 \mathrm{~Hz}, 2 \mathrm{H}), 2.43$ (s, $3 \mathrm{H}), 2.07$ (s, $2 \mathrm{H}), 1.66$ (s, $3 \mathrm{H}), 1.64$ (s, $3 \mathrm{H})$, $1.61-1.51(\mathrm{~m}, 11 \mathrm{H}) ;{ }^{13} \mathbf{C} \mathbf{N M R}\left(125 \mathrm{MHz}, \mathrm{CDCl}_{3}\right)$ : $\delta 143.4,137.0,129.8,129.1,127.2,126.0$, 108.6, 64.3, 64.3, 48.9, 43.2, 38.0, 31.8, 30.6, 21.7, 21.5, 21.5, 21.1; HRMS $\left(\mathrm{ESI}^{+}\right):[\mathrm{M}+\mathrm{H}]^{+}$ calculated for $\left[\mathrm{C}_{22} \mathrm{H}_{34} \mathrm{NO}_{4} \mathrm{~S}\right]^{+}$required $408.2203 \mathrm{~m} / \mathrm{z}$, found $408.2201 \mathrm{~m} / \mathrm{z}$.

Methyl 1-(2,3-dimethylbut-2-en-1-yl)cyclohexane-1-carboxylate (SI, S57) To a solution of $i$ -

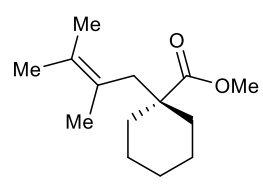
$\operatorname{Pr}_{2} \mathrm{NH}(1.20 \mathrm{~mL}, 8.54 \mathrm{mmol})$ in THF $(11 \mathrm{~mL})$ at $0^{\circ} \mathrm{C}$ was treated dropwise via syringe with $n$-BuLi $(3.40 \mathrm{~mL}, 8.54 \mathrm{mmol})$ in hexanes $(2.5 \mathrm{M})$ and the resulting solution was stirred at $0{ }^{\circ} \mathrm{C}$ for $15 \mathrm{~min}$. Methyl cyclohexanecarboxylate $(1.00$ $\mathrm{mL}, 7.11 \mathrm{mmol})$ was added dropwise and the resulting solution was stirred for $15 \mathrm{~min} . \mathbf{S 5 3}$ (1.39 g, $8.54 \mathrm{mmol})$ in THF (2 mL) was added and the resulting solution was stirred at $\mathrm{rt}$ for $16 \mathrm{~h}$. The reaction mixture was quenched with sat. aq. $\mathrm{NH}_{4} \mathrm{Cl}(50 \mathrm{~mL})$ and extracted with $\mathrm{Et}_{2} \mathrm{O}(3 \times 50 \mathrm{~mL})$. The combined organic extracts were washed with $\mathrm{H}_{2} \mathrm{O}$ and brine, dried over $\mathrm{Na}_{2} \mathrm{SO}_{4}$, filtered, and concentrated under reduced pressure to give crude $\mathbf{S 5 7}$ as an yellow oil. The crude oil was purified by chromatography on $\mathrm{SiO}_{2}$ (10\% EtOAc in hexanes) to give $\mathbf{S 5 7}$ (1.68 g) as a yellow oil, which was used without further purification.

1-(2,3-Dimethylbut-2-en-1-yl)cyclohexane-1-carboxylic acid (SI, S58) To a solution of crude<smiles>CC(C)=C(C)CC1(C(=O)O)CCCCC1</smiles>

S57 (1.68 g) and $\mathrm{LiOH}(2.28 \mathrm{~g}, 95.0 \mathrm{mmol})$ in $\mathrm{EtOH}(19 \mathrm{~mL})$ and $\mathrm{H}_{2} \mathrm{O}(19 \mathrm{~mL})$ was stirred at reflux for $44 \mathrm{~h}$. The reaction mixture was cooled to rt, diluted with $\mathrm{H}_{2} \mathrm{O}$ and extracted with $\mathrm{Et}_{2} \mathrm{O}(3 \mathrm{x})$. The combined organic extracts were dried with $\mathrm{Na}_{2} \mathrm{SO}_{4}$, filtered through a thin pad of $\mathrm{SiO}_{2}$, and concentrated under reduced pressure to give recovered $\mathbf{S 5 7}(0.710 \mathrm{~g})$ as a yellow oil. The aqueous washes were acidified to $\mathrm{pH}$ 2 with $6 \mathrm{M}$ aq. $\mathrm{HCl}(75 \mathrm{~mL})$ and extracted with $\mathrm{E}_{\mathrm{t} 2} \mathrm{O}(3 \mathrm{x})$. The organic extracts were washed with $\mathrm{H}_{2} \mathrm{O}(2 \mathrm{x})$ and brine $(1 \mathrm{x})$, dried with $\mathrm{Na} 2 \mathrm{SO} 4$, filtered through a thin pad of $\mathrm{SiO}_{2}$, and concentrated under reduced pressure to give crude $\mathbf{S 5 8}(0.649 \mathrm{~g}, 3.09 \mathrm{mmol}, 43 \%$ over two steps) as a yellow solid.

Mp 55-57 ${ }^{\circ} \mathrm{C}$; IR (ATR): v 2924.8, 2857.3, 1685.4, 1451.3, $1246.8 \mathrm{~cm}^{-1} ;{ }^{1} \mathbf{H}$ NMR (400 MHz, $\left.\mathrm{CDCl}_{3}\right): \delta 10.83 \mathrm{z}($ br s, $1 \mathrm{H}), 2.37(\mathrm{~s}, 2 \mathrm{H}), 2.13(\mathrm{~d}, J=13.0 \mathrm{~Hz}, 2 \mathrm{H}), 1.66(\mathrm{~s}, 3 \mathrm{H}), 1.65-1.57(\mathrm{~m}$, $9 \mathrm{H}), 1.43-1.28$ (m, $2 \mathrm{H}), 1.28-1.12(\mathrm{~m}, 3 \mathrm{H}) ;{ }^{13} \mathbf{C ~ N M R}\left(100 \mathrm{MHz}, \mathrm{CDCl}_{3}\right): \delta 182.7,128.9,123.9$, 48.7 , 46.4 34.8, 25.9, 23.8, 21.5, 21.1, 20.7; HRMS $\left(\mathrm{ESI}^{+}\right)$: $[\mathrm{M}-\mathrm{H}]^{-}$calculated for $\left[\mathrm{C}_{13} \mathrm{H}_{21} \mathrm{O}_{2}\right]^{-}$ required $209.1547 \mathrm{~m} / \mathrm{z}$, found $209.1548 \mathrm{~m} / \mathrm{z}$.

1-(tert-Butyl)-4-methyl-4-(2,3-dimethylbut-2-en-1-yl)piperidine-1,4-dicarboxylate (SI, S59)<smiles>CC(=O)C1(CC(C)=C(C)C)CC[NH2+]CC1</smiles>
A solution of $i-\operatorname{Pr}_{2} \mathrm{NH}(0.17 \mathrm{~mL}, 1.2 \mathrm{mmol})$ in $\mathrm{THF}(2.5 \mathrm{~mL})$ at $0{ }^{\circ} \mathrm{C}$ was treated dropwise via syringe with $n$-BuLi $(0.48 \mathrm{~mL}, 1.2 \mathrm{mmol})$ in hexanes $(2.5 \mathrm{M})$ over 10 minutes and the resulting solution was stirred at $0{ }^{\circ} \mathrm{C}$ for $15 \mathrm{~min} .1$-(tert-butyl) 4-methyl piperidine-1,4-dicarboxylate $(0.247 \mathrm{~g}, 1.0 \mathrm{mmol})$ was added dropwise and the resulting solution was stirred at $0{ }^{\circ} \mathrm{C}$ for $30 \mathrm{~min}$. $\mathbf{S 5 3}(0.13 \mathrm{~mL}, 1.2 \mathrm{mmol})$ was added dropwise and the resulting solution was allowed to warm to $\mathrm{rt}$ and stirred for $1 \mathrm{~h}$. The reaction mixture was quenched with sat. aq. $\mathrm{NH}_{4} \mathrm{Cl}(30 \mathrm{~mL})$ and extracted with $\mathrm{Et}_{2} \mathrm{O}(3 \times 30 \mathrm{~mL})$. The 
combined organic extracts were washed with $\mathrm{H}_{2} \mathrm{O}(2 \mathrm{x})$ and brine (2x), dried over $\mathrm{MgSO}_{4}$, filtered, and concentrated under reduced pressure to give crude $\mathbf{S 5 9}$ as an yellow oil. The crude oil was purified by chromatography on $\mathrm{SiO}_{2}(10 \%$ EtOAc in hexanes) to give $\mathbf{S 5 9}(0.18 \mathrm{~g}, 0.55 \mathrm{mmol}$, $55 \%)$ as a clear, colorless oil.

IR (ATR): $v$ 2971.0, 2922.4, 2865.3, 1691.2, 1418.8, 1166.3, $1143.4 \mathrm{~cm}^{-1}$; ${ }^{\mathbf{1}} \mathbf{H}$ NMR (500 MHz, $\mathrm{CDCl}_{3}$ ): $\delta 3.95$ (br s, $\left.2 \mathrm{H}\right), 3.68(\mathrm{~s}, 3 \mathrm{H}), 2.72$ (br s, $\left.2 \mathrm{H}\right), 2.34(\mathrm{~s}, 2 \mathrm{H}), 2.12(\mathrm{~d}, J=13.3 \mathrm{~Hz}, 2 \mathrm{H})$, $1.63(\mathrm{~s}, 2 \mathrm{H}), 1.63(\mathrm{~s}, 6 \mathrm{H}), 1.57(\mathrm{~s}, 3 \mathrm{H}), 1.45(\mathrm{~s}, 9 \mathrm{H}), 1.42-1.33(\mathrm{~m}, 2 \mathrm{H}) ;{ }^{13} \mathrm{C} \mathrm{NMR}(125 \mathrm{MHz}$, $\left.\mathrm{CDCl}_{3}\right): \delta 176.3,155.1,129.3,123.2,79.5,51.8,47.4,45.7,34.0,28.6,21.4,21.0,20.5$; HRMS $\left(\mathrm{ESI}^{+}\right):[\mathrm{M}+\mathrm{Na}]^{+}$calculated for $\left[\mathrm{C}_{18} \mathrm{H}_{31} \mathrm{NO}_{4} \mathrm{Na}\right]^{+}$required $348.2145 \mathrm{~m} / \mathrm{z}$, found $348.2141 \mathrm{~m} / \mathrm{z}$.

Methyl-4-(2,3-dimethylbut-2-en-1-yl)piperidine-4-carboxylate (SI, S60). A solution of S59

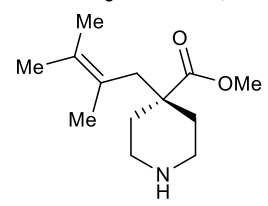
$(2.50 \mathrm{~g}, 7.68 \mathrm{mmol})$ and trifluoroacetic acid $(2.95 \mathrm{~mL}, 38.5 \mathrm{mmol})$ in $\mathrm{CH}_{2} \mathrm{Cl}_{2}$ (8 $\mathrm{mL})$ was stirred at $\mathrm{rt}$ for $2 \mathrm{~h}$. The reaction mixture was diluted with $\mathrm{CH}_{2} \mathrm{Cl}_{2}(15$ $\mathrm{mL}$ ) and $1 \mathrm{M}$ aq. $\mathrm{NaOH}$ was added to $\mathrm{pH} 12$. The layers were separated and the aqueous phase was extracted with $\mathrm{Et}_{2} \mathrm{O}(3 \times 30 \mathrm{~mL})$ and the combined organic extracts were dried over $\mathrm{Na}_{2} \mathrm{SO}_{4}$, filtered, and concentrated under reduced pressure to give crude S60 (1.93 $\mathrm{g})$ as a yellow oil which was used without further purification.

Methyl-4-(2,3-dimethylbut-2-en-1-yl)-1-tosylpiperidine-4-carboxylate (SI, S61). To a solution<smiles>COC(=O)C1(CC(C)=C(C)C)CCNCC1</smiles>
of $\mathbf{S 6 0}$ (1.13 g, $5.00 \mathrm{mmol})$ and $\mathrm{Et}_{3} \mathrm{~N}$ (1.05 mL, $\left.7.50 \mathrm{mmol}\right)$ in $\mathrm{CH}_{2} \mathrm{Cl}_{2}(21 \mathrm{~mL})$ at $0{ }^{\circ} \mathrm{C}$ was added $\mathrm{TsCl}(1.05 \mathrm{~g}, 5.50 \mathrm{mmol})$ in a single portion and the resulting solution was stirred at $\mathrm{rt}$ for $23 \mathrm{~h}$. The reaction mixture was concentrated under reduced pressure, taken up in $\mathrm{Et}_{2} \mathrm{O}$, eluted through a thin pad of $\mathrm{SiO}_{2}$, and concentrated under reduced pressure to give $\mathbf{S 6 1}$ as a yellow oil. The crude residue was purified by chromatography on $\mathrm{SiO}_{2}$ (15\% EtOAc in hexanes) to give $\mathbf{S 6 1}$ (1.07 g, $2.82 \mathrm{mmol}$, 37\% over two steps) as a white solid.

Mp 112-114 ${ }^{\circ} \mathrm{C}$; IR (ATR): v 2921.6, 2853.1, 1721.3, 1331.2, $1158.6 \mathrm{~cm}^{-1}$; ${ }^{\mathbf{1}} \mathbf{H}$ NMR (500 MHz, $\left.\mathrm{CDCl}_{3}\right): \delta 7.60(\mathrm{~d}, J=8.2 \mathrm{~Hz}, 2 \mathrm{H}), 7.29(\mathrm{~d}, J=8.1 \mathrm{~Hz}, 2 \mathrm{H}), 3.69-3.63(\mathrm{~m}, 2 \mathrm{H}), 3.56(\mathrm{~s}, 3 \mathrm{H})$, $2.42(2,3 \mathrm{H}), 2.31$ (s, $2 \mathrm{H}), 2.29-2.22(\mathrm{~m}, 2 \mathrm{H}), 2.21-2.15(\mathrm{~m}, 2 \mathrm{H}), 1.64-1.55(\mathrm{~m}, 8 \mathrm{H}), 1.53$ (s, $3 \mathrm{H}) ;{ }^{13} \mathrm{C}$ NMR $\left(125 \mathrm{MHz}, \mathrm{CDCl}_{3}\right): \delta 175.8,143.5,133.7,129.8,129.7,127.7,122.8,51.9,46.8$, 45.4, 44.2, 33.4, 21.7, 21.4, 21.0, 20.5; HRMS $\left(\mathrm{ESI}^{+}\right):[\mathrm{M}+\mathrm{Na}]^{+}$calculated for $\left[\mathrm{C}_{20} \mathrm{H}_{29} \mathrm{NO}_{4} \mathrm{SNa}\right]^{+}$ required $402.1710 \mathrm{~m} / \mathrm{z}$, found $402.1706 \mathrm{~m} / \mathrm{z}$.

(4-(2,3-Dimethylbut-2-en-1-yl)-1-tosylpiperidin-4-yl)methanol (SI, S62). To a suspension of

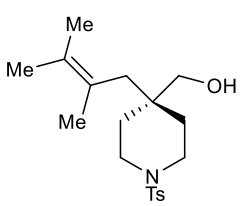
$\mathrm{LiAlH}_{4}(0.102 \mathrm{~g}, 2.70 \mathrm{mmol})$ in $\mathrm{Et}_{2} \mathrm{O}(4.5 \mathrm{~mL})$ at $0{ }^{\circ} \mathrm{C}$ was added a solution of S61 (0.342 $\mathrm{g})$ in $\mathrm{Et}_{2} \mathrm{O}(9.5 \mathrm{~mL})$ dropwise via syringe and the resulting solution was stirred at $\mathrm{rt}$ for $1.5 \mathrm{~h}$. The mixture was cooled to $0{ }^{\circ} \mathrm{C}$, quenched with $3 \mathrm{M}$ aq. $\mathrm{NaOH}(5 \mathrm{~mL})$, and stirred for $15 \mathrm{~min}$. The reaction mixture was diluted with $\mathrm{E}_{\mathrm{t} 2} \mathrm{O}$ $(20 \mathrm{~mL})$, dried over $\mathrm{Na}_{2} \mathrm{SO}_{4}$, filtered through a pad of celite, and concentrated under reduced pressure to give crude $\mathbf{S 6 2}(0.247 \mathrm{~g})$ as a clear oil. The crude oil was purified by chromatography on $\mathrm{SiO}_{2}(40 \% \mathrm{EtOAc}$ in hexanes) to give $\mathbf{S 6 2}(0.184 \mathrm{~g}, 0.52 \mathrm{mmol}, 58 \%)$ as a white solid. 
Mp 129-130 ${ }^{\circ} \mathrm{C}$; IR (ATR): v 3497.0, 2908.1, 2854.3, 1318.0, $1157.8 \mathrm{~cm}^{-1}$; ${ }^{1} \mathbf{H}$ NMR (500 MHz, $\left.\mathrm{CDCl}_{3}\right): \delta 7.64(\mathrm{~d}, J=8.3 \mathrm{~Hz}, 2 \mathrm{H}), 7.32(\mathrm{~d}, J=7.9 \mathrm{~Hz}, 2 \mathrm{H}), 3.38(\mathrm{~d}, J=5.9 \mathrm{~Hz}, 2 \mathrm{H}), 3.34-3.27$ (m, 2 H), 2.75-2.65 (m, 2 H), 2.44 (s, 3 H), 2.08 (s, 2 H), 1.70-1.66 (m, 6 H), 1.64 (s, 3 H), 1.64$1.60(\mathrm{~m}, 4 \mathrm{H}), 1.49(\mathrm{t}, J=6.0 \mathrm{~Hz}, 1 \mathrm{H}) ;{ }^{13} \mathbf{C ~ N M R}\left(125 \mathrm{MHz}, \mathrm{CDCl}_{3}\right): \delta 143.6,133.3,129.8$, 129.3, 127.9, 125.4, 66.4, 42.6, 42.3, 38.0, 32.0, 21.8, 21.7, 21.5, 21.1; HRMS (ESI $\left.{ }^{+}\right):[\mathrm{M}+\mathrm{Na}]^{+}$ calculated for $\left[\mathrm{C}_{19} \mathrm{H}_{29} \mathrm{NO}_{3} \mathrm{SNa}\right]^{+}$required $374.1760 \mathrm{~m} / \mathrm{z}$, found $374.1759 \mathrm{~m} / \mathrm{z}$.

(E)- $N$-(Hex-4-en-1-yl)-4-methylbenzenesulfonamide (SI, S63). Synthesized according to the $\sim_{\mathrm{NHTs}}$ method of Marcotullio and coworkers. ${ }^{11}$ All spectral data were in agreement with previously reported values.

\section{Optimization Studies for Oxidative Amination}

Table S1. Optimization of Photocatalytic Oxidative Amination

\begin{tabular}{|c|c|c|c|}
\hline Me & & $\begin{array}{l}\text { photocat. } \\
\text { oxidant } \\
\text { v TFA } \\
\underset{\mathrm{CE}, \mathrm{rt}}{\longrightarrow} \\
\text { light }\end{array}$ & $\overbrace{4}^{\mathrm{Me}}$ \\
\hline entry ${ }^{[a]}$ & photocat. & oxidant & $\%$ yield $^{[b]}$ \\
\hline 1 & $\mathrm{MesAcrPh}^{+}$ & $\mathrm{CuBr}_{2}$ & $0 \%$ \\
\hline 2 & $\mathrm{MesAcrPh}^{+}$ & $\mathrm{Cu}(\mathrm{OTf})_{2}$ & $3 \%$ \\
\hline 3 & $\mathrm{MesAcrPh}^{+}$ & $\mathrm{Cu}(\mathrm{OAc})_{2}$ & $48 \%$ \\
\hline 4 & $\mathrm{MesAcrPh}^{+}$ & $\mathrm{Cu}(\mathrm{TFA})_{2}$ & $57 \%$ \\
\hline 5 & $\mathrm{MesAcrPh}^{+}$ & $\mathrm{Cu}(\mathrm{OPiv})_{2}$ & $57 \%$ \\
\hline 6 & $\mathrm{MesAcrPh}^{+}$ & $\mathrm{Cu}(\mathrm{EH})_{2}$ & $87 \%$ \\
\hline 7 & $\mathrm{MesAcrMe}^{+}$ & $\mathrm{Cu}(\mathrm{EH})_{2}$ & $52 \%$ \\
\hline 8 & TPPT & $\mathrm{Cu}(\mathrm{EH})_{2}$ & $24 \%$ \\
\hline $9^{[c]}$ & $\mathrm{MesAcrPh}^{+}$ & $\mathrm{Cu}(\mathrm{EH})_{2}$ & $28 \%$ \\
\hline 10 & none & $\mathrm{Cu}(\mathrm{EH})_{2}$ & $0 \%$ \\
\hline 11 & $\mathrm{MesAcrPh}^{+}$ & none & $0 \%$ \\
\hline $12^{[d]}$ & $\mathrm{MesAcrPh}^{+}$ & $\mathrm{Cu}(\mathrm{EH})_{2}$ & $0 \%$ \\
\hline $\begin{array}{l}\mathrm{BF}_{4}{ }^{-} \\
T P P T\end{array}$ & & & $\begin{array}{l}\mathrm{Me}^{+} \mathrm{BF}_{4}^{-} \\
\text {MesAcrMe }\end{array}$ \\
\hline
\end{tabular}

General Procedure for Optimization Studies: A solution of 1 ( $0.10 \mathrm{mmol})$, copper(II) salt $(0.20$ $\mathrm{mmol})$, trifluoroacetic acid $(0.007 \mathrm{~mL}, 0.1 \mathrm{mmol})$, and photocatalyst $(0.0025 \mathrm{mmol}, 2.5 \mathrm{~mol} \%)$ in 1,2-DCE (4 mL) was degassed (freeze-pump-thaw, 3 cycles of $5 \mathrm{~min}$ each) and the resulting solution was stirred at $\mathrm{rt}$ under irradiation by two $450 \mathrm{~nm}$ blue LED flood lamps for $16 \mathrm{~h}$. The reaction mixture was diluted with $\mathrm{Et}_{2} \mathrm{O}$, eluted through a thin pad of $\mathrm{SiO}_{2}$, and concentrated under reduced pressure to give the crude reaction mixtures. Yields of 4 were determined by ${ }^{1} \mathrm{H}$ NMR analysis of the unpurified reaction mixtures using phenanthrene as an internal standard. 


\section{Oxidative Heterofunctionalization Reactions}

General Procedure for Oxidative Amination and Oxygenation: A solution of alkene (1 equiv), $\mathrm{Cu}(\mathrm{EH})_{2}$ (2 equiv), trifluoroacetic acid or $p$-toluenesulfonic acid monohydrate (1-2 equiv), and $\mathrm{MesAcrPh}^{+}(0.025$ equiv, $2.5 \mathrm{~mol} \%)$ in 1,2-DCE $(0.025 \mathrm{M})$ was degassed (freeze-pump-thaw, 3 cycles of 5 min each) and the resulting solution was stirred for the indicated time at $\mathrm{rt}$ under irradiation by two $15 \mathrm{~W}$ blue LED flood lamps. The reaction mixtures were diluted with $\mathrm{CH}_{2} \mathrm{Cl}_{2}$, washed with $1 \mathrm{M}$ aq. $\mathrm{NaOH}(3 \mathrm{x})$, eluted through a thin pad of $\mathrm{SiO}_{2}$ with $\mathrm{Et}_{2} \mathrm{O}$, and concentrated under reduced pressure. The residue was purified by chromatography on $\mathrm{SiO}_{2}$ to afford pure product.

4,4-Dimethyl-2-(prop-1-en-2-yl)-1-tosylpyrrolidine (Table 2, 4). Synthesized according to the

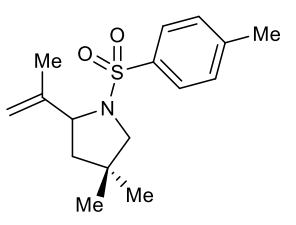
general procedure using $1(0.088 \mathrm{~g}, 0.30 \mathrm{mmol}), \mathrm{Cu}(\mathrm{EH})_{2}(0.210 \mathrm{~g}, 0.600$ $\mathrm{mmol})$, TFA $(0.023 \mathrm{~mL}, 0.30 \mathrm{mmol})$, and $\mathrm{MesAcrMe}^{+}(0.0036 \mathrm{~g}, 0.0075$ $\mathrm{mmol})$ and irradiating for $18 \mathrm{~h}$. After chromatography on $\mathrm{SiO}_{2}(10 \%$ EtOAc in hexanes), 4 was isolated as a white solid $(0.066 \mathrm{~g}, 0.22 \mathrm{mmol}, 76 \%)$.

Mp 78-81 ${ }^{\circ}$ C; IR (ATR): $v$ 2955.7, 2925.8, 1597.7, 1371.2, $1155.2 \mathrm{~cm}^{-1} ;{ }^{\mathbf{1}} \mathbf{H}$ NMR $(500 \mathrm{MHz}$, $\left.\mathrm{CDCl}_{3}\right): \delta 7.73-7.68(\mathrm{~m}, 2 \mathrm{H}), 7.33-7.27(\mathrm{~m}, 2 \mathrm{H}), 5.01-4.89(\mathrm{~m}, 1 \mathrm{H}), 4.83(\mathrm{t}, J=1.5 \mathrm{~Hz}, 1 \mathrm{H})$, 4.11-3.98 (m, $1 \mathrm{H}), 3.26$ (dd, $J=10.6,1.1 \mathrm{~Hz}, 1 \mathrm{H}), 3.19$ (d, $J=10.6 \mathrm{~Hz}, 1 \mathrm{H}), 2.43$ (s, $3 \mathrm{H}), 1.72$ $(\mathrm{dd}, J=1.5,0.8 \mathrm{~Hz}, 3 \mathrm{H}), 1.68-1.61(\mathrm{~m}, 2 \mathrm{H}), 1.03(\mathrm{~s}, 3 \mathrm{H}), 0.58(\mathrm{~s}, 3 \mathrm{H}) ;{ }^{13} \mathbf{C} \mathbf{N M R}(125 \mathrm{MHz}$, $\left.\mathrm{CDCl}_{3}\right): \delta 145.4,143.3,135.4,129.5,127.6,112.1,65.7,62.1,46.4,37.5,26.4,26.0,21.7,17.1$; HRMS $\left(\mathrm{ESI}^{+}\right):[\mathrm{M}+\mathrm{H}]^{+}$calculated for $\left[\mathrm{C}_{16} \mathrm{H}_{24} \mathrm{NO}_{2} \mathrm{~S}\right]^{+}$required $294.1522 \mathrm{~m} / \mathrm{z}$, found $294.1520 \mathrm{~m} / \mathrm{z}$.

4,4-Dimethyl-1-(phenylsulfonyl)-2-(prop-1-en-2-yl)pyrrolidine (Table 2, 5). Synthesized

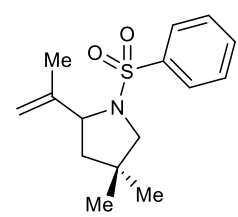
according to the general procedure using $\mathbf{S 3}(0.083 \mathrm{~g}, 0.30 \mathrm{mmol}), \mathbf{C u}(\mathrm{EH})_{2}(0.210$ $\mathrm{g}, 0.600 \mathrm{mmol})$, TFA $(0.023 \mathrm{~mL}, 0.30 \mathrm{mmol})$, and $\operatorname{MesAcrMe}^{+}(0.0036 \mathrm{~g}, 0.0075$ mmol) and irradiating for $24 \mathrm{~h}$. After chromatography on $\mathrm{SiO}_{2}(10 \%$ EtOAc in hexanes), 5 was isolated as a white solid ( $0.066 \mathrm{~g}, 0.24 \mathrm{mmol}, 80 \%)$.

Mp 56-59 ${ }^{\circ} \mathrm{C}$; IR (ATR): v 2961.8, 2876.9, 1650.8, 1371.2, $1157.9 \mathrm{~cm}^{-1} ;{ }^{1} \mathbf{H}$ NMR (400 MHz, $\left.\mathrm{CDCl}_{3}\right): \delta 7.86-7.80(\mathrm{~m}, 2 \mathrm{H}), 7.61-7.47(\mathrm{~m}, 3 \mathrm{H}), 4.96(\mathrm{dt}, J=1.8,0.9 \mathrm{~Hz}, 1 \mathrm{H}), 4.83(\mathrm{t}, J=1.6$ $\mathrm{Hz}, 1 \mathrm{H}), 4.13-4.05(\mathrm{~m}, 1 \mathrm{H}), 3.29(\mathrm{dd}, J=10.6,1.1 \mathrm{~Hz}, 1 \mathrm{H}), 3.20(\mathrm{~d}, J=10.7 \mathrm{~Hz}), 1.71(\mathrm{~d}, J=$ $0.7 \mathrm{~Hz}, 3 \mathrm{H}), 1.69-1.59(\mathrm{~m}, 2 \mathrm{H}), 1.03(\mathrm{~s}, 3 \mathrm{H}), 0.56(\mathrm{~s}, 3 \mathrm{H}) ;{ }^{13} \mathbf{C} \mathbf{~ N M R}\left(100 \mathrm{MHz}, \mathrm{CDCl}_{3}\right): \delta$ 145.2, 138.4, 132.6, 128.9, 127.6, 112.2, 65.7, 62.0, 46.4, 37.6, 26.3, 25.9, 17.1; HRMS $\left(\mathrm{ESI}^{+}\right)$: $[\mathrm{M}+\mathrm{H}]^{+}$calculated for $\left[\mathrm{C}_{15} \mathrm{H}_{22} \mathrm{NO}_{2} \mathrm{~S}\right]^{+}$required $280.1366 \mathrm{~m} / \mathrm{z}$, found $280.1364 \mathrm{~m} / \mathrm{z}$.

4,4-Dimethyl-2-(prop-1-en-2-yl)-1-((4-(trifluoromethyl)phenyl)sulfonyl)pyrrolidine (Table 2,

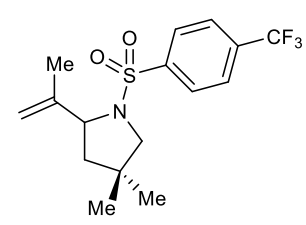

6). Synthesized according to the general procedure using $\mathbf{S 4}(0.104 \mathrm{~g}, 0.298$ $\mathrm{mmol}), \mathrm{Cu}(\mathrm{EH})_{2}(0.211 \mathrm{~g}, 0.603 \mathrm{mmol})$, TFA $(0.023 \mathrm{~mL}, 0.30 \mathrm{mmol})$, and $\mathrm{MesAcrMe}^{+}(0.0036 \mathrm{~g}, 0.0075 \mathrm{mmol})$ and irradiating for $96 \mathrm{~h}$. After chromatography on $\mathrm{SiO}_{2}(10 \%$ EtOAc in hexanes), $\mathbf{6}$ was isolated as a yellow powder $(0.067 \mathrm{~g}, 0.19 \mathrm{mmol}, 65 \%)$.

Mp 78-81 ${ }^{\circ} \mathrm{C}$; IR (ATR): v 2966.6, 2862.2, 1453.3, $1319.2 \mathrm{~cm}^{-1} ;{ }^{\mathbf{1}} \mathbf{H}$ NMR (500 MHz, $\left.\mathrm{CDCl}_{3}\right): \delta$ $7.95(\mathrm{~d}, J=8.1 \mathrm{~Hz}, 2 \mathrm{H}), 7.78$ (d, $J=8.2 \mathrm{~Hz}, 2 \mathrm{H}), 4.96-4.94$ (m, $1 \mathrm{H}$ ), 4.83 (app. p, $J=1.5 \mathrm{~Hz}, 1$ 
H), 4.16 (dd, $J=9.6,7.4 \mathrm{~Hz}, 1 \mathrm{H}), 3.35$ (dd, $J=10.6,1.5 \mathrm{~Hz}, 1 \mathrm{H}), 3.19$ (d, $J=10.6 \mathrm{~Hz}, 1 \mathrm{H}$ ), 1.73 (ddd, $J=12.8,7.4,1.5 \mathrm{~Hz}, 1 \mathrm{H}), 1.67-1.62(\mathrm{~m}, 1 \mathrm{H}), 1.64(\mathrm{dd}, J=1.4,0.8 \mathrm{~Hz}, 3 \mathrm{H}), 1.06$ (s, $3 \mathrm{H}), 0.67(\mathrm{~s}, 3 \mathrm{H}) ;{ }^{13} \mathrm{C}$ NMR $\left(125 \mathrm{MHz}, \mathrm{CDCl}_{3}\right): \delta 144.6,142.4(\mathrm{q}, J=1.5 \mathrm{~Hz}), 134.2(\mathrm{q}, J=$ $33.0 \mathrm{~Hz}), 127.9,126.1(\mathrm{q}, J=3.7 \mathrm{~Hz}), 123.5(\mathrm{q}, J=272.8 \mathrm{~Hz}), 112.9,65.9,62.0,46.2,37.8,26.0$, 25.9, 17.0; HRMS $\left(\mathrm{ESI}^{+}\right)$: $[\mathrm{M}+\mathrm{H}]^{+}$calculated for $\left[\mathrm{C}_{16} \mathrm{H}_{21} \mathrm{~F}_{3} \mathrm{NO}_{2} \mathrm{~S}\right]^{+}$required $348.1240 \mathrm{~m} / \mathrm{z}$, found $348.1233 \mathrm{~m} / \mathrm{z}$.

1-((4-Methoxyphenyl)sulfonyl)-4,4-dimethyl-2-(prop-1-en-2-yl)pyrrolidine (Table 2, 7).

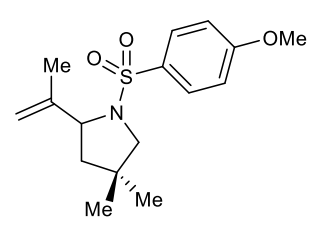
Synthesized according to the general procedure using S5 (0.093 g, 0.30 $\mathrm{mmol}), \mathrm{Cu}(\mathrm{EH})_{2}(0.212 \mathrm{~g}, 0.606 \mathrm{mmol})$, TFA $(0.023 \mathrm{~mL}, 0.30 \mathrm{mmol})$, and $\mathrm{MesAcrMe}^{+}(0.0036 \mathrm{~g}, 0.0075 \mathrm{mmol})$ and irradiating for $8 \mathrm{~h}$. After chromatography on $\mathrm{SiO}_{2}$ (15\% EtOAc in hexanes), 7 was isolated as a clear, colorless oil (0.067 g, $0.22 \mathrm{mmol}, 72 \%)$.

IR (ATR): $v$ 2960.1, 1651.8, 1336.0, $1151.4 \mathrm{~cm}^{-1} ;{ }^{1} \mathbf{H}$ NMR (400 MHz, $\left.\mathrm{CDCl}_{3}\right): \delta$ 7.81-7.68 (m, $2 \mathrm{H}), 7.00-6.95$ (m, $2 \mathrm{H}), 4.98-4.92(\mathrm{~m}, 1 \mathrm{H}), 4.82$ (app. p, $J=1.5 \mathrm{~Hz}, 1 \mathrm{H}), 4.09-4.00$ (m, $1 \mathrm{H})$, $3.87(\mathrm{~s}, 3 \mathrm{H}), 3.25(\mathrm{dd}, J=10.6,1.0 \mathrm{~Hz}, 1 \mathrm{H}), 3.19(\mathrm{~d}, J=10.7 \mathrm{~Hz}, 1 \mathrm{H}), 1.73(\mathrm{dd}, J=1.5,0.8 \mathrm{~Hz}$, $3 \mathrm{H}), 1.68-1.61(\mathrm{~m}, 2 \mathrm{H}), 1.04(\mathrm{~s}, 3 \mathrm{H}), 0.60$ (s, $3 \mathrm{H}) ;{ }^{13} \mathbf{C ~ N M R}\left(100 \mathrm{MHz}, \mathrm{CDCl}_{3}\right): \delta 162.9$, 145.5, 130.2, 129.7, 114.0, 112.0, 65.7, 62.1, 55.7, 46.4, 37.5, 26.4, 26.1, 17.1; HRMS (ESI $\left.{ }^{+}\right)$: $[\mathrm{M}+\mathrm{H}]^{+}$calculated for $\left[\mathrm{C}_{16} \mathrm{H}_{24} \mathrm{NO}_{3} \mathrm{~S}\right]^{+}$required $310.1471 \mathrm{~m} / \mathrm{z}$, found $310.1468 \mathrm{~m} / \mathrm{z}$.

4,4-Dimethyl-2-(prop-1-en-2-yl)-1-(o-tolylsulfonyl)pyrrolidine (Table 2，8). Synthesized

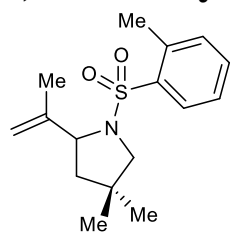
according to the general procedure using $\mathbf{S 6}(0.088 \mathrm{~g}, 0.30 \mathrm{mmol}), \mathrm{Cu}(\mathrm{EH})_{2}(0.210$ $\mathrm{g}, 0.600 \mathrm{mmol})$, TFA $(0.023 \mathrm{~mL}, 0.30 \mathrm{mmol})$, and MesAcrMe ${ }^{+}(0.0036 \mathrm{~g}, 0.0075$ mmol) and irradiating for $24 \mathrm{~h}$. After chromatography on $\mathrm{SiO}_{2}\left(10 \% \mathrm{Et}_{2} \mathrm{O}\right.$ in hexanes), 8 was isolated as a white solid (0.053 g, $0.18 \mathrm{mmol}, 61 \%)$.

Mp 48-50 ${ }^{\circ} \mathrm{C}$; IR (ATR): v 3070.6, 2959.2, 2870.9, 1650.4, 1332.0, $1155.8 \mathrm{~cm}^{-1} ;{ }^{\mathbf{1}} \mathbf{H}$ NMR (500 $\left.\mathrm{MHz}, \mathrm{CDCl}_{3}\right): \delta 7.87(\mathrm{dd}, J=7.8,1.4 \mathrm{~Hz}, 1 \mathrm{H}), 7.39(\mathrm{td}, J=7.5,1.4 \mathrm{~Hz}, 1 \mathrm{H}), 7.26-7.21(\mathrm{~m}, 2$ $\mathrm{H}), 4.81(\mathrm{~s}, 1 \mathrm{H}), 4.58(\mathrm{p}, J=1.5 \mathrm{~Hz}, 1 \mathrm{H}), 4.41(\mathrm{dd}, J=9.8,7.4 \mathrm{~Hz}, 1 \mathrm{H}), 3.69$ (dd, $J=10.5,1.8$ Hz, $1 \mathrm{H}), 3.14$ (d, $J=10.4 \mathrm{~Hz}, 1 \mathrm{H}), 2.65$ (s, $3 \mathrm{H}), 1.80$ (ddd, $J=12.6,7.4,1.7 \mathrm{~Hz}, 1 \mathrm{H}), 1.64$ (dd, $J=12.6,9.8 \mathrm{~Hz}, 1 \mathrm{H}), 1.38(\mathrm{~s}, 3 \mathrm{H}), 1.09(\mathrm{~s}, 3 \mathrm{H}), 1.00(\mathrm{~s}, 3 \mathrm{H}) ;{ }^{13} \mathbf{C ~ N M R}\left(125 \mathrm{MHz}, \mathrm{CDCl}_{3}\right): \delta$ 144.0, 138.7, 137.5, 132.4, 132.3, 130.3, 125.8, 113.2, 65.5, 62.2, 46.6, 37.8, 25.9, 25.8, 20.9, 16.6; HRMS (ESI ${ }^{+}$): $[\mathrm{M}+\mathrm{H}]^{+}$calculated for $\left[\mathrm{C}_{16} \mathrm{H}_{24} \mathrm{NO}_{3} \mathrm{~S}\right]^{+}$required $294.1522 \mathrm{~m} / \mathrm{z}$, found $294.1519 \mathrm{~m} / \mathrm{z}$.

1-(Benzylsulfonyl)-4,4-dimethyl-2-(prop-1-en-2-yl)pyrrolidine (Table 2, 10). Synthesized

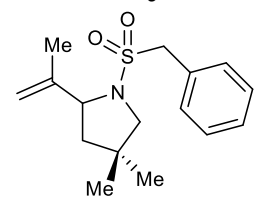
according to the general procedure using $\mathbf{S 8}(0.089 \mathrm{~g}, 0.30 \mathrm{mmol}), \mathrm{Cu}(\mathrm{EH})_{2}$ $(0.210 \mathrm{~g}, 0.600 \mathrm{mmol}), \mathrm{TFA}(0.023 \mathrm{~mL}, 0.30 \mathrm{mmol})$, and $\mathrm{MesAcrMe}^{+}(0.0036 \mathrm{~g}$, $0.0075 \mathrm{mmol})$ and irradiating for $42 \mathrm{~h}$. After chromatography on $\mathrm{SiO}_{2}(10 \%$ EtOAc in hexanes), 10 was isolated as a yellow oil (0.078 g, $0.27 \mathrm{mmol}, 88 \%)$.

IR (ATR): v 3069.2, 3034.3, 2958.7, 2871.6, 1650.4, $1329.7 \mathrm{~cm}^{-1} ;{ }^{1} \mathbf{H} \mathbf{N M R}\left(500 \mathrm{MHz}, \mathrm{CDCl}_{3}\right)$ : $\delta$ 7.44-7.32 (m, $5 \mathrm{H}), 5.05(\mathrm{~d}, J=0.9 \mathrm{~Hz}, 1 \mathrm{H}), 4.90-4.87(\mathrm{~m}, 1 \mathrm{H}), 4.50(\mathrm{dd}, J=9.4,7.6 \mathrm{~Hz}, 1$ H), $4.25(\mathrm{~d}, J=13.6 \mathrm{~Hz}, 1 \mathrm{H}), 4.14(\mathrm{~d}, J=13.7 \mathrm{~Hz}, 1 \mathrm{H}), 3.31(\mathrm{dd}, J=10.5,1.6 \mathrm{~Hz}, 1 \mathrm{H}), 2.78(\mathrm{~d}$, $J=10.5 \mathrm{~Hz}, 1 \mathrm{H}), 1.83(\mathrm{ddd}, J=12.6,7.5,1.7 \mathrm{~Hz}, 1 \mathrm{H}), 1.72(\mathrm{~s}, 3 \mathrm{H}), 1.58(\mathrm{dd}, J=12.6,9.4 \mathrm{~Hz}$, $1 \mathrm{H}), 1.05$ (s, $3 \mathrm{H}), 1.03$ (s, $3 \mathrm{H}) ;{ }^{13} \mathrm{C}$ NMR (125 MHz, $\left.\mathrm{CDCl}_{3}\right): \delta$ 144.9, 130.9, 129.4, 128.7, 
128.6, 112.9, 61.9, 59.5, 46.0, 38.5, 25.8, 25.7, 17.8; HRMS $\left(\mathrm{ESI}^{+}\right)$: $[\mathrm{M}+\mathrm{H}]^{+}$calculated for $\left[\mathrm{C}_{16} \mathrm{H}_{24} \mathrm{NO}_{2} \mathrm{~S}\right]^{+}$required $294.1522 \mathrm{~m} / \mathrm{z}$, found $294.1521 \mathrm{~m} / \mathrm{z}$.

1-(Cyclopropylsulfonyl)-4,4-dimethyl-2-(prop-1-en-2-yl)pyrrolidine (Table $2, \quad 11)$. Me $0 \leqslant 11$ Synthesized according to the general procedure using S9 (0.073 g, $0.30 \mathrm{mmol})$, $\mathrm{Cu}(\mathrm{EH})_{2}(0.212 \mathrm{~g}, 0.606 \mathrm{mmol})$, TFA $(0.023 \mathrm{~mL}, 0.30 \mathrm{mmol})$, and $\mathrm{MesAcrMe}^{+}$ $(0.0036 \mathrm{~g}, 0.0075 \mathrm{mmol})$ and irradiating for $24 \mathrm{~h}$. After chromatography on $\mathrm{SiO}_{2}$ (10-30\% $\mathrm{Et}_{2} \mathrm{O}$ in hexanes), 11 was isolated as a yellow oil (0.065 g, $0.27 \mathrm{mmol}$, $90 \%)$.

IR (ATR): v 2958.8, 2871.8, 1650.6, 1332.6, $1141.6 \mathrm{~cm}^{-1} ;{ }^{1} \mathbf{H} \mathbf{N M R}\left(500 \mathrm{MHz}, \mathrm{CDCl}_{3}\right): \delta 4.92(\mathrm{~s}$, $1 \mathrm{H}), 4.74$ (app. t, $J=1.8 \mathrm{~Hz}, 1 \mathrm{H}), 4.36$ (dd, $J=9.4,7.4 \mathrm{~Hz}, 1 \mathrm{H}), 3.35$ (dd, $J=10.4,1.5 \mathrm{~Hz}, 1$ H), $3.05(\mathrm{~d}, J=10.4 \mathrm{~Hz}, 1 \mathrm{H}), 2.62(\mathrm{ddd}, J=12.2,7.4,5.3 \mathrm{~Hz}, 1 \mathrm{H}), 1.83(\mathrm{ddd}, J=12.6,7.4,1.5$ $\mathrm{Hz}, 1 \mathrm{H}), 1.70(\mathrm{~s}, 3 \mathrm{H}), 1.60(\mathrm{dd}, J=12.5,9.5 \mathrm{~Hz}, 1 \mathrm{H}), 1.07(\mathrm{~s}, 3 \mathrm{H}), 1.06(\mathrm{~s}, 3 \mathrm{H}), 0.99-0.88(\mathrm{~m}$, $4 \mathrm{H}) ;{ }^{13} \mathrm{C}$ NMR $\left(125 \mathrm{MHz}, \mathrm{CDCl}_{3}\right): \delta 145.6,111.1,64.4,61.2,45.6,37.5,27.4,25.7,25.5,17.0$, 4.5, 4.2; HRMS $\left(\mathrm{ESI}^{+}\right):[\mathrm{M}+\mathrm{H}]^{+}$calculated for $\left[\mathrm{C}_{12} \mathrm{H}_{22} \mathrm{NO}_{2} \mathrm{~S}\right]^{+}$required $244.1366 \mathrm{~m} / \mathrm{z}$, found $244.1365 \mathrm{~m} / \mathrm{z}$.

1-(tert-Butylsulfonyl)-4,4-dimethyl-2-(prop-1-en-2-yl)pyrrolidine (Table 2, 12). Synthesized according to the general procedure using S11 $(0.078 \mathrm{~g}, 0.30 \mathrm{mmol}), \mathrm{Cu}(\mathrm{EH})_{2}(0.210$
$\mathrm{me}, \mathrm{me}, 0.600 \mathrm{mmol}), \mathrm{TFA}(0.023 \mathrm{~mL}, 0.30 \mathrm{mmol})$, and $\mathrm{MesAcrMe}^{+}(0.0036 \mathrm{~g}, 0.0075$

IR (ATR): $v$ 2958.3, 2868.4, 1649.1, 1458.4, 1308.0, $1120.3 \mathrm{~cm}^{-1} ;{ }^{1} \mathbf{H}$ NMR $\left(500 \mathrm{MHz}, \mathrm{CDCl}_{3}\right)$ : $\delta 5.00$ (app. s, $1 \mathrm{H}), 4.83(\mathrm{t}, J=1.6 \mathrm{~Hz}, 1 \mathrm{H}), 4.74(\mathrm{dd}, J=9.3,7.9 \mathrm{~Hz}, 1 \mathrm{H}), 3.58(\mathrm{dd}, J=10.8$, $1.9 \mathrm{~Hz}, 1 \mathrm{H}), 2.91(\mathrm{~d}, J=10.8 \mathrm{~Hz}, 1 \mathrm{H}), 1.82(\mathrm{ddd}, J=12.7,7.9,1.9 \mathrm{~Hz}, 1 \mathrm{H}), 1.73(\mathrm{~s}, 3 \mathrm{H}), 1.61$ $(\mathrm{dd}, J=12.6,9.3 \mathrm{~Hz}, 1 \mathrm{H}), 1.32(\mathrm{~s}, 9 \mathrm{H}), 1.09$ (app. s, $6 \mathrm{H}) ;{ }^{13} \mathbf{C} \mathbf{N M R}\left(125 \mathrm{MHz}, \mathrm{CDCl}_{3}\right): \delta 144.6$, 114.4, 65.9, 63.7, 60.3 45.2, 39.3, 25.7, 25.4, 24.4, 17.2; HRMS $\left(\mathrm{ESI}^{+}\right)$: $[\mathrm{M}+\mathrm{Na}]^{+}$calculated for $\left[\mathrm{C}_{13} \mathrm{H}_{25} \mathrm{NO}_{2} \mathrm{SNa}\right]^{+}$required $282.1497 \mathrm{~m} / \mathrm{z}$, found $282.1498 \mathrm{~m} / \mathrm{z}$.

$\mathbf{N , N , 4 , 4 - T e t r a m e t h y l - 2 - ( p r o p - 1 - e n - 2 - y l ) p y r r o l i d i n e - 1 - s u l f o n a m i d e ~ ( T a b l e ~ 2 , ~ 1 3 ) . ~ S y n t h e s i z e d ~}$

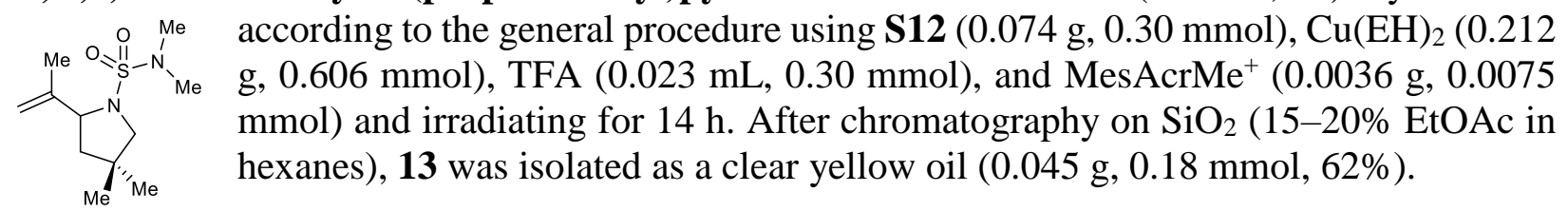

IR (ATR): $v$ 2957.2, 2871.5, 1650.6, 1333.9, $1142.1 \mathrm{~cm}^{-1} ;{ }^{\mathbf{1}} \mathbf{H}$ NMR (500 MHz, $\left.\mathrm{CDCl}_{3}\right): \delta 4.99$ (br. s, $1 \mathrm{H}), 4.83(\mathrm{p}, J=1.5 \mathrm{~Hz}, 1 \mathrm{H}), 4.36(\mathrm{dd}, J=9.4,7.6 \mathrm{~Hz}, 1 \mathrm{H}), 3.41$ (dd, $J=10.5,1.6 \mathrm{~Hz}, 1$ H), $3.03(\mathrm{~d}, J=10.5 \mathrm{~Hz}, 1 \mathrm{H}), 2.77(\mathrm{~s}, 6 \mathrm{H}), 1.84$ (ddd, $J=12.6,7.5,1.6 \mathrm{~Hz}, 1 \mathrm{H}), 1.75(\mathrm{~s}, 3 \mathrm{H})$, $1.63(\mathrm{dd}, J=12.6,9.5 \mathrm{~Hz}, 1 \mathrm{H}), 1.13(\mathrm{~s}, 3 \mathrm{H}), 1.09$ (s, $3 \mathrm{H}) ;{ }^{13} \mathbf{C ~ N M R}\left(125 \mathrm{MHz}, \mathrm{CDCl}_{3}\right): \delta 145.3$, 112.3, 66.0, 62.9, 46.2, 38.4, 38.0, 26.3, 26.2, 17.5; HRMS $\left(\mathrm{ESI}^{+}\right)$: $[\mathrm{M}+\mathrm{H}]^{+}$calculated for $\left[\mathrm{C}_{11} \mathrm{H}_{23} \mathrm{~N}_{2} \mathrm{O}_{2} \mathrm{~S}\right]^{+}$required $247.1475 \mathrm{~m} / \mathrm{z}$, found $247.1471 \mathrm{~m} / \mathrm{z}$. 
4,4-Diphenyl-2-(prop-1-en-2-yl)tetrahydrofuran (Table 2, 14). Synthesized according to the<smiles>C=C(C)C1CC(c2ccccc2)CO1</smiles>
general procedure using $\mathbf{S 1 3}(0.079 \mathrm{~g}, 0.30 \mathrm{mmol}), \mathrm{Cu}(\mathrm{EH})_{2}(0.210 \mathrm{~g}, 0.600 \mathrm{mmol})$, TFA $(0.023 \mathrm{~mL}, 0.30 \mathrm{mmol})$, and $\operatorname{MesAcrMe}^{+}(0.0036 \mathrm{~g}, 0.0075 \mathrm{mmol})$ and irradiating for $16 \mathrm{~h}$. After chromatography on $\mathrm{SiO}_{2}$ (2\% EtOAc in hexanes), 14 was isolated as a yellow oil (0.063 g, $0.24 \mathrm{mmol}, 80 \%)$.

IR (ATR): $v$ 3058.1, 3026.7, 2970.9, 2862.1, 1652.4, $696.8 \mathrm{~cm}^{-1} ;{ }^{1} \mathbf{H} \mathbf{~ N M R}\left(500 \mathrm{MHz}, \mathrm{CDCl}_{3}\right): \delta$ 7.37-7.26 (m, $6 \mathrm{H}), 7.25-7.16(\mathrm{~m}, 4 \mathrm{H}), 5.04-4.99$ (m, $1 \mathrm{H}), 4.80$ (app. s, $1 \mathrm{H}), 4.76$ (dd, $J=8.7$, $1.3 \mathrm{~Hz}, 1 \mathrm{H}), 4.41(\mathrm{dd}, J=10.4,5.9 \mathrm{~Hz}, 1 \mathrm{H}), 4.11(\mathrm{~d}, J=8.7 \mathrm{~Hz}, 1 \mathrm{H}), 2.60(\mathrm{ddd}, J=12.0,5.9$, $1.3 \mathrm{~Hz}, 1 \mathrm{H}), 2.48(\mathrm{dd}, J=12.0,10.3 \mathrm{~Hz}, 1 \mathrm{H}), 1.73(\mathrm{~s}, 3 \mathrm{H}) ;{ }^{13} \mathbf{C} \mathbf{N M R}\left(125 \mathrm{MHz}, \mathrm{CDCl}_{3}\right): \delta$ 146.2, 145.6, 145.6, 128.6, 128.5, 127.3, 127.3, 126.7, 126.4, 110.5, 81.7, 77.5, 56.3, 44.0, 18.0; HRMS $\left(\mathrm{ESI}^{+}\right):[\mathrm{M}+\mathrm{H}]^{+}$calculated for $\left[\mathrm{C}_{19} \mathrm{H}_{21} \mathrm{O}\right]^{+}$required $265.1587 \mathrm{~m} / \mathrm{z}$, found $265.1585 \mathrm{~m} / \mathrm{z}$.

3,3-Diphenyl-5-(prop-1-en-2-yl)dihydrofuran-2(3H)-one (Table 2, 15). Synthesized according<smiles>C=C(N)C1CC(c2ccccc2)C(=O)O1</smiles>
to the general procedure using $\mathbf{S 1 4}(0.085 \mathrm{~g}, 0.30 \mathrm{mmol}), \mathrm{Cu}(\mathrm{EH})_{2}(0.211 \mathrm{~g}, 0.603$ mmol), TFA (0.023 mL, $0.30 \mathrm{mmol})$, and MesAcrMe ${ }^{+}(0.0036 \mathrm{~g}, 0.0075 \mathrm{mmol})$ and irradiating for $18 \mathrm{~h}$. After chromatography on $\mathrm{SiO}_{2}$ (4\% EtOAc in hexanes), 15 was isolated as a yellow oil that solidified upon standing $(0.063 \mathrm{~g}, 0.19 \mathrm{mmol}, 62 \%)$.

Mp 83-85 ${ }^{\circ} \mathrm{C}$; IR (ATR): v 3059.6, 3022.3, 2932.9, 2890.6, 1760.3, $1179.4 \mathrm{~cm}^{-1}$; ${ }^{\mathbf{1}} \mathbf{H}$ NMR (500 $\mathrm{MHz}_{\mathrm{CDCl}}$ ): $\delta$ 7.42-7.36 (m, $\left.4 \mathrm{H}\right), 7.35-7.29(\mathrm{~m}, 5 \mathrm{H}), 7.28-7.23(\mathrm{~m}, 1 \mathrm{H}), 5.12(\mathrm{~s}, 1 \mathrm{H}), 4.99$ $(\mathrm{s}, 1 \mathrm{H}), 4.74(\mathrm{dd}, J=11.0,5.0 \mathrm{~Hz}, 1 \mathrm{H}), 3.06(\mathrm{dd}, J=12.9,5.0 \mathrm{~Hz}, 1 \mathrm{H}), 2.79$ (dd, $J=12.9,11.0$ $\mathrm{Hz}, 1 \mathrm{H}), 1.81(\mathrm{~s}, 3 \mathrm{H}) ;{ }^{13} \mathbf{C}$ NMR $\left(125 \mathrm{MHz}, \mathrm{CDCl}_{3}\right): \delta 177.0,142.1,141.5,139.7,129.1,128.5$, $127.9,127.8,127.5,127.4,113.5,79.4,58.4,42.7,17.6$; HRMS $\left(\mathrm{ESI}^{+}\right):[\mathrm{M}+\mathrm{H}]^{+}$calculated for $\left[\mathrm{C}_{19} \mathrm{H}_{19} \mathrm{O}_{2}\right]^{+}$required $296.1645 \mathrm{~m} / \mathrm{z}$, found $296.1642 \mathrm{~m} / \mathrm{z}$.

Dimethyl 5-(prop-1-en-2-yl)-1-tosylpyrrolidine-3,3-dicarboxylate (Table 2, 16). Synthesized

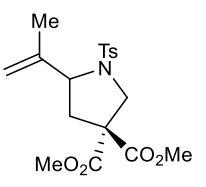
according to the general procedure using $\mathbf{S 1 8}(0.114 \mathrm{~g}, 0.297 \mathrm{mmol}), \mathrm{Cu}(\mathrm{EH})_{2}(0.209$ g, $0.597 \mathrm{mmol})$, TFA $(0.023 \mathrm{~mL}, 0.30 \mathrm{mmol})$, and MesAcrMe ${ }^{+}(0.0036 \mathrm{~g}, 0.0075$ mmol) and irradiating for $48 \mathrm{~h}$. After chromatography on $\mathrm{SiO}_{2}(10 \%$ EtOAc in hexanes), 16 was isolated as a red oil (0.082 $\mathrm{g}, 0.22 \mathrm{mmol}, 72 \%)$.

IR (ATR): $v$ 2962.8, 2922.1, 2866.4, 1717.6, $1655.5 \mathrm{~cm}^{-1} ;{ }^{\mathbf{1}} \mathbf{H}$ NMR (500 MHz, $\left.\mathrm{CDCl}_{3}\right): \delta 7.69$ $(\mathrm{d}, J=8.3 \mathrm{~Hz}, 2 \mathrm{H}), 7.32(\mathrm{~d}, J=8.0 \mathrm{~Hz}, 2 \mathrm{H}), 4.99(\mathrm{~s}, 1 \mathrm{H}), 4.89(\mathrm{t}, J=1.6 \mathrm{~Hz}, 1 \mathrm{H}), 4.14(\mathrm{t}, J=$ $7.8 \mathrm{~Hz}, 1 \mathrm{H}), 4.05(\mathrm{ABq}, J=11.6 \mathrm{~Hz}, 1 \mathrm{H}), 3.96(\mathrm{ABq}, J=11.5 \mathrm{~Hz}, 1 \mathrm{H}), 3.71(\mathrm{~s}, 3 \mathrm{H}), 3.52(\mathrm{~s}, 3$ H), $2.51(\mathrm{dd}, J=13.0,7.8 \mathrm{~Hz}, 1 \mathrm{H}), 2.44(\mathrm{~s}, 3 \mathrm{H}), 2.28(\mathrm{dd}, J=13.2,7.9 \mathrm{~Hz}, 1 \mathrm{H}), 1.74(\mathrm{~s}, 3 \mathrm{H})$; ${ }^{13}$ C NMR $\left(125 \mathrm{MHz}, \mathrm{CDCl}_{3}\right): \delta 169.7,169.3,143.7,143.6,134.6,129.7,127.9,113.4,65.1,58.3$, 54.6, 53.3, 38.5, 21.7, 17.3; HRMS $\left(\mathrm{ESI}^{+}\right)$: $[\mathrm{M}+\mathrm{H}]^{+}$calculated for $\left[\mathrm{C}_{18} \mathrm{H}_{24} \mathrm{NO}_{6} \mathrm{~S}\right]^{+}$required $382.1319 \mathrm{~m} / \mathrm{z}$, found $382.1314 \mathrm{~m} / \mathrm{z}$.

(5-(Prop-1-en-2-yl)-1-tosylpyrrolidine-3,3-diyl)dimethanol (Table 2, 17). Synthesized

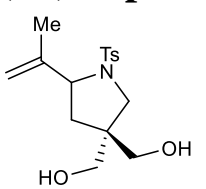
according to the general procedure using $\mathbf{S 1 9}(0.098 \mathrm{~g}, 0.30 \mathrm{mmol}), \mathrm{Cu}(\mathrm{EH})_{2}(0.212$ $\mathrm{g}, 0.606 \mathrm{mmol})$, TFA $(0.023 \mathrm{~mL}, 0.30 \mathrm{mmol})$, and $\mathrm{MesAcrMe}^{+}(0.0036 \mathrm{~g}, 0.0075$ mmol) and irradiating for $36 \mathrm{~h}$. After chromatography on $\mathrm{SiO}_{2}(70 \%$ EtOAc in hexanes), 17 was isolated as a white powder $(0.037 \mathrm{~g}, 0.11 \mathrm{mmol}, 38 \%)$. 
Mp 112-115 ${ }^{\circ} \mathrm{C}$; IR (ATR): v 3314.9, 2923.5, 2873.9, 1451.8, 1339.7, $1158.1 \mathrm{~cm}^{-1}$; ${ }^{\mathbf{1}} \mathbf{H}$ NMR $\left(500 \mathrm{MHz}, \mathrm{CDCl}_{3}\right): \delta 7.71(\mathrm{~d}, J=8.2 \mathrm{~Hz}, 2 \mathrm{H}), 7.32(\mathrm{~d}, J=8.1 \mathrm{~Hz}, 2 \mathrm{H}), 4.95(\mathrm{~s}, 1 \mathrm{H}), 4.84(\mathrm{t}, J$ $=1.5 \mathrm{~Hz}, 1 \mathrm{H}), 4.04(\mathrm{t}, J=8.3 \mathrm{~Hz}, 1 \mathrm{H}), 3.69(\mathrm{t}, J=5.4 \mathrm{~Hz}, 2 \mathrm{H}), 3.46(\mathrm{ABq}, J=11.3 \mathrm{~Hz}, 1 \mathrm{H})$, $3.32(\mathrm{ABq}, 11.5 \mathrm{~Hz}, 1 \mathrm{H}), 3.32-3.29(\mathrm{~m}, 1 \mathrm{H}), 3.24$ (dd, $J=10.9,5.4 \mathrm{~Hz}, 1 \mathrm{H}), 2.44$ (s, $3 \mathrm{H}), 2.18$ $(\mathrm{dt}, J=10.1,5.1 \mathrm{~Hz}, 2 \mathrm{H}), 1.81(\mathrm{dd}, J=13.4,8.1 \mathrm{~Hz}, 1 \mathrm{H}), 1.73$ (s, $3 \mathrm{H}), 1.61$ (dd, $J=13.4,8.7$ $\mathrm{Hz}, 1 \mathrm{H}) ;{ }^{13} \mathrm{C}$ NMR $\left(125 \mathrm{MHz}, \mathrm{CDCl}_{3}\right): \delta 144.7,143.7,134.8,129.7,127.8,112.6,68.4$, 66.4, 65.0, 54.0, 47.5, 36.9, 21.7, 17.2; HRMS $\left(\mathrm{ESI}^{+}\right)$: $[\mathrm{M}+\mathrm{H}]^{+}$calculated for $\left[\mathrm{C}_{16} \mathrm{H}_{24} \mathrm{NO}_{4} \mathrm{~S}\right]^{+}$required $326.1421 \mathrm{~m} / \mathrm{z}$, found $326.1416 \mathrm{~m} / \mathrm{z}$.

4,4-bis(((tert-Butyldimethylsilyl)oxy)methyl)-2-(prop-1-en-2-yl)-1-tosylpyrrolidine (Table 2, Me 18). Synthesized according to the general procedure using S20 (0.163 g, 0.293 mmol), $\mathrm{Cu}(\mathrm{EH})_{2}(0.210 \mathrm{~g}, 0.600 \mathrm{mmol})$, TFA $(0.023 \mathrm{~mL}, 0.30 \mathrm{mmol})$, and MesAcrMe $^{+}(0.0036 \mathrm{~g}, 0.0075 \mathrm{mmol})$ and irradiating for $15 \mathrm{~h}$. After chromatography on $\mathrm{SiO}_{2}(10 \%$ EtOAc in hexanes), $\mathbf{1 8}$ was isolated as a yellow oil $(0.121 \mathrm{~g}, 0.218 \mathrm{mmol}, 75 \%)$.

IR (ATR): v 2950.2, 2931.1, 2856.7, 1601.2, 1341.0, $1079.0 \mathrm{~cm}^{-1} ;{ }^{1} \mathbf{H}$ NMR (500 MHz, CDCl 3$)$ : $\delta$ 7.72-7.67 (m, $2 \mathrm{H}), 7.34-7.29(\mathrm{~m}, 2 \mathrm{H}), 4.94(\mathrm{dt}, J=1.8,0.9 \mathrm{~Hz}, 1 \mathrm{H}), 4.85(\mathrm{t}, J=1.6 \mathrm{~Hz}, 1 \mathrm{H})$, $3.84(\mathrm{t}, J=8.3 \mathrm{~Hz}, 1 \mathrm{H}), 3.49$ (d, $J=9.6 \mathrm{~Hz}, 1 \mathrm{H}), 3.41(\mathrm{~d}, J=9.6 \mathrm{~Hz}, 1 \mathrm{H}), 3.35(\mathrm{~d}, J=11.0 \mathrm{~Hz}$, $1 \mathrm{H}), 3.14(\mathrm{~d}, J=11.1 \mathrm{~Hz}, 1 \mathrm{H}), 3.05(\mathrm{~d}, J=9.7 \mathrm{~Hz}, 1 \mathrm{H}), 2.82(\mathrm{~d}, J=9.7 \mathrm{~Hz}, 1 \mathrm{H}), 2.43(\mathrm{~s}, 3 \mathrm{H})$, $1.78(\mathrm{~s}, 3 \mathrm{H}), 1.72(\mathrm{dd}, J=13.2,8.0 \mathrm{~Hz}, 1 \mathrm{H}), 1.65$ (dd, $J=13.2,8.8 \mathrm{~Hz}, 1 \mathrm{H}), 0.87$ (s, $9 \mathrm{H}), 0.79$ $(\mathrm{s}, 9 \mathrm{H}), 0.01(\mathrm{~d}, J=2.1 \mathrm{~Hz}, 6 \mathrm{H}),-0.12(\mathrm{~d}, J=3.4 \mathrm{~Hz}, 6 \mathrm{H}) ;{ }^{13} \mathbf{C} \mathbf{N M R}\left(125 \mathrm{MHz}, \mathrm{CDCl}_{3}\right): \delta$ $145.5,143.4,134.1,129.7,127.9,112.1,65.4,64.5,63.0,54.2,48.3,35.6,26.0,25.9,21.7,18.4$, 18.2, 17.0, -5.4, -5.5, -5.6, -5.6; HRMS $\left(\mathrm{ESI}^{+}\right)$: $[\mathrm{M}+\mathrm{H}]^{+}$calculated for $\left[\mathrm{C}_{28} \mathrm{H}_{51} \mathrm{NO}_{4} \mathrm{SSi}_{2}\right]^{+}$required $554.3150 \mathrm{~m} / \mathrm{z}$, found $554.3157 \mathrm{~m} / \mathrm{z}$.

8,8-Dimethyl-3-(prop-1-en-2-yl)-2-tosyl-7,9-dioxa-2-azaspiro[4.5]decane (Table 2, 19).

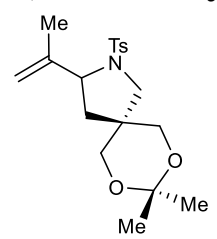
Synthesized according to the general procedure using $\mathbf{S 2 1}(0.085 \mathrm{~g}, 0.23 \mathrm{mmol})$, $\mathrm{Cu}(\mathrm{EH})_{2}(0.164 \mathrm{~g}, 0.468 \mathrm{mmol})$, TFA $(0.018 \mathrm{~mL}, 0.23 \mathrm{mmol})$, and MesAcrMe ${ }^{+}$ $(0.0027 \mathrm{~g}, 0.0059 \mathrm{mmol})$ and irradiating for $42 \mathrm{~h}$. After chromatography on $\mathrm{SiO}_{2}$ (30\% EtOAc in hexanes), 19 was isolated as a clear, colorless oil (0.060 g, 0.16 mmol, $71 \%)$.

IR (ATR): $v$ 2989.7, 2927.4, 2865.4, 1343.8, $1158.3 \mathrm{~cm}^{-1} ;{ }^{\mathbf{1}} \mathbf{H}$ NMR (500 MHz, $\left.\mathrm{CDCl}_{3}\right): \delta 7.74$ $7.76(\mathrm{~m}, 2 \mathrm{H}), 7.35-7.29(\mathrm{~m}, 2 \mathrm{H}), 4.97(\mathrm{dt}, J=1.7,0.9 \mathrm{~Hz}, 1 \mathrm{H}), 4.86(\mathrm{p}, J=1.5 \mathrm{~Hz}, 1 \mathrm{H}), 3.92$ $(\mathrm{t}, J=8.1 \mathrm{~Hz}, 1 \mathrm{H}), 3.69(\mathrm{dd}, J=11.5,1.4 \mathrm{~Hz}, 1 \mathrm{H}), 3.63(\mathrm{~d}, J=11.5 \mathrm{~Hz}, 1 \mathrm{H}), 3.43(\mathrm{ABq}, J=$ $11.2 \mathrm{~Hz}, 1 \mathrm{H}), 3.39(\mathrm{ABq}, J=11.2 \mathrm{~Hz}, 1 \mathrm{H}), 3.25(\mathrm{~d}, J=11.5 \mathrm{~Hz}, 1 \mathrm{H}), 3.14(\mathrm{dd}, J=11.5,1.4 \mathrm{~Hz}$, $1 \mathrm{H}), 2.44(\mathrm{~s}, 3 \mathrm{H}), 1.81(\mathrm{dd}, J=13.5,8.1 \mathrm{~Hz}, 1 \mathrm{H}), 1.75(\mathrm{~s}, 3 \mathrm{H}), 1.58(\mathrm{dd}, J=13.4,8.0 \mathrm{~Hz}, 1 \mathrm{H})$, 1.36 (s, $3 \mathrm{H}), 1.35$ (s, $3 \mathrm{H}) ;{ }^{13} \mathbf{C}$ NMR (125 MHz, $\left.\mathrm{CDCl}_{3}\right): \delta$ 144.6, 143.7, 134.2, 129.7, 127.9, 112.7, 98.3, 67.3, 66.5, 64.7, 55.8, 40.7, 37.9, 24.9, 22.5, 21.7, 17.4; HRMS (ESI $\left.{ }^{+}\right):[\mathrm{M}+\mathrm{H}]^{+}$ calculated for $\left[\mathrm{C}_{19} \mathrm{H}_{28} \mathrm{NO}_{4} \mathrm{~S}\right]^{+}$required $366.1734 \mathrm{~m} / \mathrm{z}$, found $366.1731 \mathrm{~m} / \mathrm{z}$.

2-(Prop-1-en-2-yl)-1-tosylpyrrolidine (Table 2, 20). Synthesized according to the general Me $\quad$ procedure using S24 $(0.079 \mathrm{~g}, 0.30 \mathrm{mmol}), \mathrm{Cu}(\mathrm{EH})_{2}(0.210 \mathrm{~g}, 0.600 \mathrm{mmol}), \mathrm{TFA}(0.023$ $\left.{ }_{N}^{\text {Ts }} \mathrm{mL}, 0.30 \mathrm{mmol}\right)$, and $\operatorname{MesAcrMe}^{+}(0.0036 \mathrm{~g}, 0.0075 \mathrm{mmol})$ and irradiating for $30 \mathrm{~h}$. 
After chromatography on $\mathrm{SiO}_{2}(20 \%$ EtOAc in hexanes), 20 was isolated as a clear, colorless oil that solidified upon standing to a yellow solid (0.065 g, $0.24 \mathrm{mmol}, 83 \%)$.

Mp 69-72 ${ }^{\circ} \mathrm{C}$; IR (ATR): v 2979.9, 2951.6, 2865.8, 1655.7, 1490.1, $1333.2 \mathrm{~cm}^{-1} ;{ }^{\mathbf{1}} \mathbf{H}$ NMR $(500$ $\left.\mathrm{MHz}, \mathrm{CDCl}_{3}\right): \delta 7.72(\mathrm{~d}, J=8.2 \mathrm{~Hz}, 2 \mathrm{H}), 7.31(\mathrm{~d}, J=8.0 \mathrm{~Hz}, 2 \mathrm{H}), 5.03-4.98(\mathrm{~m}, 1 \mathrm{H}), 4.88-$ $4.85(\mathrm{~m}, 1 \mathrm{H}), 4.04(\mathrm{t}, J=6.3 \mathrm{~Hz}, 1 \mathrm{H}), 3.46(\mathrm{ddd}, J=10.2,7.1,5.1 \mathrm{~Hz}, 1 \mathrm{H}), 3.29(\mathrm{dt}, J=10.2$, $7.3 \mathrm{~Hz}, 1 \mathrm{H}), 2.43$ (s, $3 \mathrm{H}), 1.84-1.75(\mathrm{~m}, 1 \mathrm{H}), 1.74(\mathrm{~s}, 3 \mathrm{H}), 1.72-1.66$ (m, $1 \mathrm{H}), 1.59-1.51$ (m, 1 $\mathrm{H}) ;{ }^{13} \mathrm{C}$ NMR $\left(125 \mathrm{MHz}, \mathrm{CDCl}_{3}\right): \delta 145.2,143.4,135.1,129.7,127.7,111.9,65.1,49.4,31.5$, 24.2, 21.7, 18.8; HRMS $\left(\mathrm{ESI}^{+}\right)$: $[\mathrm{M}+\mathrm{H}]^{+}$calculated for $\left[\mathrm{C}_{14} \mathrm{H}_{20} \mathrm{NO}_{2} \mathrm{~S}\right]^{+}$required $266.1209 \mathrm{~m} / \mathrm{z}$, found $266.1212 \mathrm{~m} / \mathrm{z}$.

2-(Prop-1-en-2-yl)-4-tosylmorpholine (Table 2, 21). Synthesized according to the general Me procedure using S26 (0.074 g, $0.26 \mathrm{mmol}), \mathrm{Cu}(\mathrm{EH})_{2}(0.184 \mathrm{~g}, 0.526 \mathrm{mmol}), \mathrm{TFA}(0.020$ o mL, $0.26 \mathrm{mmol})$, and $\mathrm{MesAcrMe}^{+}(0.0030 \mathrm{~g}, 0.0065 \mathrm{mmol})$ and irradiating for $42 \mathrm{~h}$. After chromatography on $\mathrm{SiO}_{2}(10 \%$ EtOAc in hexanes), 21 was isolated as a white solid $(0.037 \mathrm{~g}, 0.13 \mathrm{mmol}, 51 \%)$.

Mp 102-104 ${ }^{\circ} \mathrm{C}$; IR (ATR): v 2976.2, 2913.2, 2854.5, 1653.4, $1339.3 \mathrm{~cm}^{-1} ;{ }^{\mathbf{1}} \mathbf{H}$ NMR (500 MHz, $\left.\mathrm{CDCl}_{3}\right): \delta 7.64(\mathrm{~d}, J=8.2 \mathrm{~Hz}, 2 \mathrm{H}), 7.34(\mathrm{~d}, J=8.0 \mathrm{~Hz}, 2 \mathrm{H}), 4.99(\mathrm{~s}, 1 \mathrm{H}), 4.92(\mathrm{t}, J=1.8 \mathrm{~Hz}, 1$ $\mathrm{H}), 3.99-3.92(\mathrm{~m}, 2 \mathrm{H}), 3.72(\mathrm{td}, J=11.6,2.7 \mathrm{~Hz}, 1 \mathrm{H}), 3.67(\mathrm{dt}, J=11.4,2.2 \mathrm{~Hz}, 1 \mathrm{H}), 3.54(\mathrm{dq}$, $J=11.5,2.0 \mathrm{~Hz}, 1 \mathrm{H}), 2.45(\mathrm{~s}, 3 \mathrm{H}), 2.41(\mathrm{td}, J=11.6,3.5 \mathrm{~Hz}, 1 \mathrm{H}), 2.14(\mathrm{dd}, J=11.3,10.2 \mathrm{~Hz}$, $1 \mathrm{H}), 1.72(\mathrm{~s}, 3 \mathrm{H}) ;{ }^{13} \mathbf{C ~ N M R}\left(125 \mathrm{MHz}, \mathrm{CDCl}_{3}\right): \delta 144.1,142.2,132.3,129.9,128.0,112.8,78.3$, 66.0, 49.7, 45.6, 21.7, 19.3; HRMS $\left(\mathrm{ESI}^{+}\right):[\mathrm{M}+\mathrm{H}]^{+}$calculated for $\left[\mathrm{C}_{14} \mathrm{H}_{20} \mathrm{NO}_{3} \mathrm{~S}\right]^{+}$required $282.1158 \mathrm{~m} / \mathrm{z}$, found $282.1159 \mathrm{~m} / \mathrm{z}$.

8-Benzyl-3-(prop-1-en-2-yl)-2-oxa-8-azaspiro[4.5]decane (Table 2, 22). Synthesized according $\|_{\mathrm{Ne}}$ to the general procedure using $\mathbf{S 3 0}(0.081 \mathrm{~g}, 0.30 \mathrm{mmol}), \mathrm{Cu}(\mathrm{EH})_{2}(0.211 \mathrm{~g}, 0.603$ $\mathrm{mmol})$, TsOH$\cdot \mathrm{H}_{2} \mathrm{O}(0.116 \mathrm{~g}, 0.610 \mathrm{mmol})$, and $\mathrm{MesAcrMe}^{+}(0.0036 \mathrm{~g}, 0.0075 \mathrm{mmol})$ and irradiating for $16 \mathrm{~h}$. After chromatography on $\mathrm{SiO}_{2}(40 \%$ EtOAc in hexanes with $\left.1 \% \mathrm{Et}_{3} \mathrm{~N}\right), 22$ was isolated as a yellow oil $(0.045 \mathrm{~g}, 0.17 \mathrm{mmol}, 56 \%)$.

IR (ATR): $v$ 2918.4, 2846.0, 2805.2, 1701.8, 1649.4, $1445.9 \mathrm{~cm}^{-1} ;{ }^{1} \mathbf{H}$ NMR $(500 \mathrm{MHz}$, $\left.\mathrm{CDCl}_{3}\right): \delta 7.33-7.29(\mathrm{~m}, 4 \mathrm{H}), 7.27-7.21(\mathrm{~m}, 1 \mathrm{H}), 4.98(\mathrm{~s}, 1 \mathrm{H}), 4.78(\mathrm{t}, J=2.0 \mathrm{~Hz}, 1$ H), 4.34 (dd, $J=9.6,6.7$ Hz, 1 H), 3.69-3.62 (m, 2 H), 3.48 (s, 3 H), 2.50-2.26 (m, 4 H), 1.93 (dd, $J=12.4,6.9 \mathrm{~Hz}, 1 \mathrm{H}), 1.71(\mathrm{~s}, 3 \mathrm{H}), 1.68-1.58(\mathrm{~m}, 4 \mathrm{H}), 1.48(\mathrm{dd}, J=12.4,9.4 \mathrm{~Hz}, 1 \mathrm{H}) ;{ }^{13} \mathrm{C}$ NMR $\left(125 \mathrm{MHz}, \mathrm{CDCl}_{3}\right): \delta 145.8,138.7,129.3,128.3,127.1,109.9,81.7,78.2,63.6,51.8,51.3$, 43.2, 36.1, 35.1, 18.1; HRMS $\left(\mathrm{ESI}^{+}\right):[\mathrm{M}+\mathrm{H}]^{+}$calculated for $\left[\mathrm{C}_{18} \mathrm{H}_{26} \mathrm{NO}^{+}\right.$required $272.2009 \mathrm{~m} / \mathrm{z}$, found $272.2006 \mathrm{~m} / \mathrm{z}$.

8-Phenyl-3-(prop-1-en-2-yl)-2-oxa-8-azaspiro[4.5]decane (Table 2, 23). Synthesized according $\|_{\mathrm{Me}}$ to the general procedure using $\mathbf{S 3 2}(0.077 \mathrm{~g}, 0.30 \mathrm{mmol}), \mathrm{Cu}(\mathrm{EH})_{2}(0.208 \mathrm{~g}, 0.594$ $\mathrm{mmol})$, TsOH$\cdot \mathrm{H}_{2} \mathrm{O}(0.116 \mathrm{~g}, 0.610 \mathrm{mmol})$, and $\mathrm{MesAcrMe}^{+}(0.0036 \mathrm{~g}, 0.0075 \mathrm{mmol})$ and irradiating for $20 \mathrm{~h}$. After chromatography on $\mathrm{SiO}_{2}$ (20\% EtOAc in hexanes), 23 was isolated as a yellow oil $(0.042 \mathrm{~g}, 0.16 \mathrm{mmol}, 55 \%)$. 
IR (ATR): $v$ 2919.9, 2839.5, 1797.1, 1497.5, $1235.9 \mathrm{~cm}^{-1} ;{ }^{1} \mathbf{H} \mathbf{~ N M R}\left(500 \mathrm{MHz}, \mathrm{CDCl}_{3}\right): \delta 7.29$ $7.22(\mathrm{~m}, 2 \mathrm{H}), 6.98-6.91(\mathrm{~m}, 2 \mathrm{H}), 6.84(\mathrm{td}, J=7.3,1.1 \mathrm{~Hz}, 1 \mathrm{H}), 5.04-4.99(\mathrm{~m}, 1 \mathrm{H}), 4.80(\mathrm{~s}, 1$ H), 4.43-4.35 (m, $1 \mathrm{H}), 3.71-3.67(\mathrm{~m}, 2 \mathrm{H}), 3.20(\mathrm{t}, J=5.8 \mathrm{~Hz}, 2 \mathrm{H}), 3.14(\mathrm{dd}, J=7.0,4.5 \mathrm{~Hz}, 2$ H), $2.00(\mathrm{dd}, J=12.6,6.9 \mathrm{~Hz}, 1 \mathrm{H}), 1.83-1.73(\mathrm{~m}, 4 \mathrm{H}), 1.73(\mathrm{~s}, 3 \mathrm{H}), 1.56(\mathrm{dd}, J=12.3,9.4 \mathrm{~Hz}$, $1 \mathrm{H}) ;{ }^{13} \mathrm{C}$ NMR $\left(125 \mathrm{MHz}, \mathrm{CDCl}_{3}\right): \delta 151.7,145.7,129.2,119.7,116.7,110.1,81.7,78.0,47.9$, 47.5, 42.7, 42.3, 35.8, 34.8, 18.3; HRMS $\left(\mathrm{ESI}^{+}\right)$: $[\mathrm{M}+\mathrm{H}]^{+}$calculated for $\left[\mathrm{C}_{17} \mathrm{H}_{24} \mathrm{NO}\right]^{+}$required $258.1852 \mathrm{~m} / \mathrm{z}$, found $258.1847 \mathrm{~m} / \mathrm{z}$.

4-((2R,5S)-5-(Prop-1-en-2-yl)tetrahydrofuran-2-yl)quinoline (Table 2, 24). Synthesized

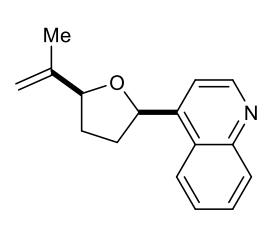

cis-24

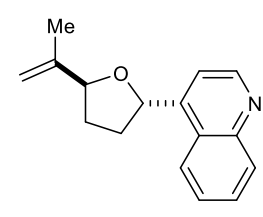

trans-24 according to the general procedure using $\mathbf{S 3 3}$ (0.067 g, 0.28 $\mathrm{mmol}), \mathrm{Cu}(\mathrm{EH})_{2}(0.211 \mathrm{~g}, 0.603 \mathrm{mmol}), \mathrm{TsOH} \cdot \mathrm{H}_{2} \mathrm{O}(0.117$ $\mathrm{g}, 0.613 \mathrm{mmol})$, and MesAcrMe ${ }^{+}(0.0036 \mathrm{~g}, 0.0075 \mathrm{mmol})$ and irradiating for $18 \mathrm{~h}$. After chromatography on $\mathrm{SiO}_{2}$ (40\% EtOAc in hexanes), 24 was isolated as a mixture of cis and trans isomers $(0.035 \mathrm{~g}, 0.15 \mathrm{mmol}, 53 \%, 1: 1 \mathrm{~d}$.r.). Analytically pure samples of each diastereomer were obtained by chromatography on $\mathrm{SiO}_{2}$ (40\% EtOAc in hexanes).

cis-24: Isolated as a 5.5:1 mixture of cis:trans diastereomers. Characteristic data:

IR (ATR): $v$ 3072.3, 3035.0, 2967.9, 2925.4, 2861.4, 1592.6, $1077.7 \mathrm{~cm}^{-1} ;{ }^{1} \mathbf{H}$ NMR (500 MHz, $\left.\mathrm{CDCl}_{3}\right): \delta 8.91(\mathrm{~d}, J=4.5 \mathrm{~Hz}, 1 \mathrm{H}), 8.15(\mathrm{~d}, J=8.5 \mathrm{~Hz}, 1 \mathrm{H}), 7.91(\mathrm{~d}, J=9.0 \mathrm{~Hz}, 1 \mathrm{H}), 7.75-7.67$ (m, $2 \mathrm{H}), 7.56$ (ddd, $J=8.4,6.8,1.3 \mathrm{~Hz}, 1 \mathrm{H}), 5.65$ (t, $J=7.3 \mathrm{~Hz}, 1 \mathrm{H}), 5.21$ (app. s, $1 \mathrm{H}), 4.96$ (app. s, $1 \mathrm{H}), 4.58-4.51(\mathrm{~m}, 1 \mathrm{H}), 2.74-2.61$ (m, $1 \mathrm{H}), 2.25-2.21(\mathrm{~m}, 1 \mathrm{H}), 1.96-1.77$ (m, $2 \mathrm{H})$, 1.89 (s, $3 \mathrm{H}) ;{ }^{13} \mathrm{C}$ NMR $\left(125 \mathrm{MHz}, \mathrm{CDCl}_{3}\right): \delta 150.6,149.2,148.2,144.8,130.4,129.1,126.6$, 125.7, 123.3, 117.0, 111.3, 83.1, 76.8, 34.0, 30.7, 18.9; HRMS $\left(\mathrm{ESI}^{+}\right)$: $[\mathrm{M}+\mathrm{H}]^{+}$calculated for $\left[\mathrm{C}_{16} \mathrm{H}_{18} \mathrm{NO}\right]^{+}$required $240.1383 \mathrm{~m} / \mathrm{z}$, found $240.1384 \mathrm{~m} / \mathrm{z}$.

\section{trans-24:}

IR (ATR): $v$ 3072.0, 3035.0, 2924.6, 2860.5, 1592.4, $1072.0 \mathrm{~cm}^{-1} ;{ }^{1} \mathbf{H}$ NMR (500 MHz, $\left.\mathrm{CDCl}_{3}\right)$ : $\delta 8.90(\mathrm{~d}, J=4.6 \mathrm{~Hz}, 1 \mathrm{H}), 8.15(\mathrm{~d}, J=8.4 \mathrm{~Hz}, 1 \mathrm{H}), 7.93(\mathrm{~d}, J=8.4 \mathrm{~Hz}, 1 \mathrm{H}), 7.72$ (ddd, $J=8.4$, 6.8, $1.4 \mathrm{~Hz}, 1 \mathrm{H}), 7.61(\mathrm{~d}, J=4.5 \mathrm{~Hz}, 1 \mathrm{H}), 7.56$ (ddd, $J=8.3,6.8,1.3 \mathrm{~Hz}, 1 \mathrm{H}), 5.82(\mathrm{t}, J=7.0$ Hz, 1 H), 5.14 (app. s, 1 H), 4.92 (app. s, 1 H), 4.77 (t, $J=6.8$ Hz, 1 H), 2.74-2.66 (m, 1 H), 2.24$2.15(\mathrm{~m}, 1 \mathrm{H}), 2.01-1.85(\mathrm{~m}, 2 \mathrm{H}), 1.83(\mathrm{~s}, 3 \mathrm{H}) ;{ }^{13} \mathbf{C} \mathbf{N M R}\left(125 \mathrm{MHz}, \mathrm{CDCl}_{3}\right): \delta 150.7,149.8$, 148.2 145.5, 130.4 129.2, 126.5, 125.7, 123.3, 116.6, 110.6, 83.2, 34.4, 31.3, 18.4; HRMS (ESI $\left.{ }^{+}\right)$: $[\mathrm{M}+\mathrm{H}]^{+}$calculated for $\left[\mathrm{C}_{16} \mathrm{H}_{18} \mathrm{NO}\right]^{+}$required $240.1383 \mathrm{~m} / \mathrm{z}$, found $240.1384 \mathrm{~m} / \mathrm{z}$.

2-(Prop-1-en-2-yl)-8-tosyl-1-oxa-8-azaspiro[4.5]decane (Table 2, 25). Synthesized according to

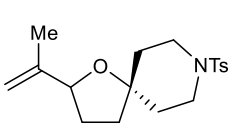
the general procedure using $\mathbf{S 3 4}(0.100 \mathrm{~g}, 0.296 \mathrm{mmol}), \mathrm{Cu}(\mathrm{EH})_{2}(0.209 \mathrm{~g}, 0.597$ mmol), TFA (0.023 mL, $0.60 \mathrm{mmol})$, and MesAcrMe ${ }^{+}(0.0036 \mathrm{~g}, 0.0075 \mathrm{mmol})$ and irradiating for $26 \mathrm{~h}$. After chromatography on $\mathrm{SiO}_{2}$ (20\% EtOAc in hexanes), 25 was isolated as a clear, colorless oil that solidified upon standing to a yellow solid $(0.057 \mathrm{~g}$, $0.17 \mathrm{mmol}, 57 \%)$.

Mp 84-86 ${ }^{\circ} \mathrm{C}$; IR (ATR): v 2949.2, 2917.6, 2857.2, 1595.0, $1344.6 \mathrm{~cm}^{-1} ;{ }^{\mathbf{1}} \mathbf{H}$ NMR (500 MHz, $\left.\mathrm{CDCl}_{3}\right): \delta 7.66-7.61(\mathrm{~m}, 2 \mathrm{H}), 7.32-7.27(\mathrm{~m}, 2 \mathrm{H}), 4.90(\mathrm{dt}, J=2.1,1.1 \mathrm{~Hz}, 1 \mathrm{H}), 4.74(\mathrm{~m}, 1 \mathrm{H})$, 4.33-4.25 (m, 1 H), 3.51-3.41 (m, 2 H), 2.85-2.74 (m, 2 H), 2.43 (s, 3 H), 2.09-1.97 (m, 1 H), 1.80-1.66 (m, $7 \mathrm{H}), 1.64$ (t, $J=1.1 \mathrm{~Hz}, 3 \mathrm{H}) ;{ }^{13} \mathbf{C ~ N M R}\left(125 \mathrm{MHz}, \mathrm{CDCl}_{3}\right): \delta 151.7,145.7,129.2$, 
119.7, 116.7, 110.1, 81.7, 78.0, 47.9, 47.5, 42.7, 42.3, 35.8, 34.8, 18.3; HRMS $\left(\mathrm{ESI}^{+}\right):[\mathrm{M}+\mathrm{H}]^{+}$ calculated for $\left[\mathrm{C}_{17} \mathrm{H}_{24} \mathrm{NO}\right]^{+}$required $258.1852 \mathrm{~m} / z$, found $258.1847 \mathrm{~m} / \mathrm{z}$.

7-(Prop-1-en-2-yl)-2-tosyl-6-oxa-2-azaspiro[3.4]octane (Table 2, 26). Synthesized according to

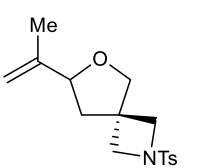
the general procedure using $\mathbf{S 3 8}(0.092 \mathrm{~g}, 0.30 \mathrm{mmol}), \mathrm{Cu}(\mathrm{EH})_{2}(0.209 \mathrm{~g}, 0.597$ $\mathrm{mmol})$, TFA ( $0.023 \mathrm{~mL}, 0.30 \mathrm{mmol})$, and $\mathrm{MesAcrMe}^{+}(0.0036 \mathrm{~g}, 0.0075 \mathrm{mmol})$ and irradiating for $96 \mathrm{~h}$. After chromatography on $\mathrm{SiO}_{2}$ (30\% $\mathrm{Et}_{2} \mathrm{O}$ in hexanes), 26 was isolated as yellow solid $(0.049 \mathrm{~g}, 0.16 \mathrm{mmol}, 54 \%)$.

Mp 95-97 ${ }^{\circ} \mathrm{C}$; IR (ATR): v 2924.2, 2867.7, 1449.0, 1342.8, $1160.0 \mathrm{~cm}^{-1} ;{ }^{1} \mathbf{H}$ NMR (500 MHz, $\left.\mathrm{CDCl}_{3}\right): \delta$ 7.76-7.30 (m, $\left.2 \mathrm{H}\right), 7.41-7.34(\mathrm{~m}, 2 \mathrm{H}), 4.93-4.89(\mathrm{~m}, 1 \mathrm{H}), 4.80-4.75(\mathrm{~m}, 1 \mathrm{H}), 4.23$ (t, $J=7.4 \mathrm{~Hz}, 1 \mathrm{H}), 3.82-3.63(\mathrm{~m}, 6 \mathrm{H}), 2.47(\mathrm{~s}, 3 \mathrm{H}), 2.08(\mathrm{dd}, J=12.9,7.1 \mathrm{~Hz}, 1 \mathrm{H}), 1.78(\mathrm{dd}, J$ $=12.9,7.7 \mathrm{~Hz}, 1 \mathrm{H}), 1.64(\mathrm{~s}, 3 \mathrm{H}) ;{ }^{13} \mathbf{C} \mathbf{N M R}\left(125 \mathrm{MHz}, \mathrm{CDCl}_{3}\right): \delta$ 144.5, 144.4, 131.7, 129.8 , 128.5, 110.8, 81.7, 60.2, 60.1, 42.1, 40.5, 21.8, 18.2; HRMS $\left(\mathrm{ESI}^{+}\right):[\mathrm{M}+\mathrm{H}]^{+}$calculated for $\left[\mathrm{C}_{16} \mathrm{H}_{22} \mathrm{NO}_{3} \mathrm{~S}\right]^{+}$required $308.1315 \mathrm{~m} / \mathrm{z}$, found $308.1312 \mathrm{~m} / \mathrm{z}$.

2-(Prop-1-en-2-yl)-2,3,3a,4,5,9b-hexahydronaphtho[1,2-b]furan (Table 2, 27-Major and 27-

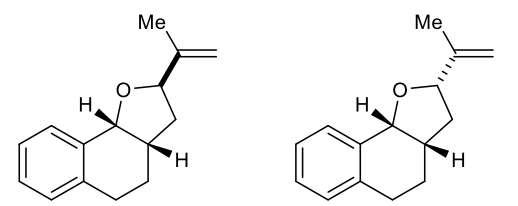

27-Major

27-Minor Minor). Synthesized according to the general procedure using $\mathbf{S 3 9}$ $(0.064 \mathrm{~g}, 0.30 \mathrm{mmol}), \mathrm{Cu}(\mathrm{EH})_{2}(0.210 \mathrm{~g}, 0.600 \mathrm{mmol}), \mathrm{TFA}(0.023$ $\mathrm{mL}, 0.30 \mathrm{mmol})$, and MesAcrMe ${ }^{+}(0.0036 \mathrm{~g}, 0.0075 \mathrm{mmol})$ and irradiating for $20 \mathrm{~h}$. After chromatography on $\mathrm{SiO}_{2}\left(2 \% \mathrm{Et}_{2} \mathrm{O}\right.$ in hexanes), 27 was isolated as a mixture of diastereomers $(0.041 \mathrm{~g}$, $0.19 \mathrm{mmol}, 65 \%, 1: 1$ d.r.) which proved inseparable by column

chromatography.

1-(2,3,3a,4,5,9b-Hexahydronaphtho[1,2-b]furan-2-yl)ethan-1-one (SI, S64-Major and S64-

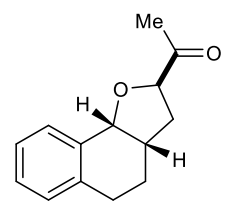

s63-Major

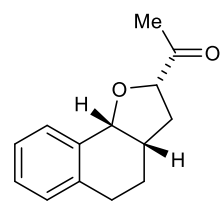

S63-Minor Minor). To a solution of 27 (0.017 g, $0.079 \mathrm{mmol}, 1.6: 1$ d.r.) in acetone $/ \mathrm{H}_{2} \mathrm{O}(1.7 \mathrm{~mL}, 10: 1)$ was added 2,6 -lutidine $(0.020 \mathrm{~mL}$, $0.16 \mathrm{mmol}), N$-methylmorpholine- $N$-oxide $(0.014 \mathrm{~g}, 0.12 \mathrm{mmol})$, and a solution of $\mathrm{OsO}_{4}\left(0.010 \mathrm{~mL}, 0.006 \mathrm{mmol}, 4 \mathrm{wt} \%\right.$ in $\left.\mathrm{H}_{2} \mathrm{O}\right)$ and the resulting solution was stirred at $\mathrm{rt}$ for $5 \mathrm{~h}$. $\mathrm{PhI}(\mathrm{OAc})_{2}(0.038$ $\mathrm{g}, 0.012 \mathrm{mmol})$ was added in a single portion and the resulting solution was stirred at $\mathrm{rt}$ for $16 \mathrm{~h}$. The reaction mixture was quenched with sat. aq. $\mathrm{Na}_{2} \mathrm{~S}_{2} \mathrm{O}_{3}$ ( 5 $\mathrm{mL})$ and the solution was extracted with EtOAc $(3 \times 10 \mathrm{~mL})$. The combined organic extracts were washed with sat. aq. $\mathrm{CuSO}_{4}(2 \times 5 \mathrm{~mL})$, dried over $\mathrm{Na}_{2} \mathrm{SO}_{4}$, filtered, and concentrated under reduced pressure to give crude $\mathbf{S 6 4}(0.019 \mathrm{~g})$ as a pale yellow oil. The crude residue was purified by chromatography on $\mathrm{SiO}_{2}\left(20-30 \% \mathrm{Et}_{2} \mathrm{O}\right.$ in hexanes) to give $\mathbf{S 6 4}$ as a clear, colorless oil (0.012 g, $0.055 \mathrm{mmol}, 70 \%, 1.7: 1$ d.r.). Analytically pure samples of each diastereomer were obtained by chromatography on $\mathrm{SiO}_{2}\left(20-25 \% \mathrm{Et}_{2} \mathrm{O}\right.$ in pentanes).

\section{$\underline{\text { S64-Major: }}$}

IR (ATR): $v$ 2925.2, 2856.6, 1713.8, 1352.0, $1071.3 \mathrm{~cm}^{-1} ;{ }^{1} \mathbf{H} \mathbf{~ N M R}\left(500 \mathrm{MHz}, \mathrm{CDCl}_{3}\right): \delta 7.50$ $7.43(\mathrm{~m}, 1 \mathrm{H}), 7.27-7.19(\mathrm{~m}, 2 \mathrm{H}), 7.17-7.11(\mathrm{~m}, 1 \mathrm{H}), 4.92(\mathrm{~d}, J=5.5 \mathrm{~Hz}, 1 \mathrm{H}), 4.47$ (app. t, $J=$ $8.0 \mathrm{~Hz}, 1 \mathrm{H}$ ), 2.81 (dt, $J=16.3,4.3 \mathrm{~Hz}, 1 \mathrm{H}$ ), 2.69 (ddd, $J=16.3,11.5,4.6 \mathrm{~Hz}, 1 \mathrm{H}$ ), 2.50 (dddd, $J=12.5,7.6,5.0,2.4 \mathrm{~Hz}, 1 \mathrm{H}), 2.34-2.26(\mathrm{~m}, 1 \mathrm{H}), 2.31$ (s, $3 \mathrm{H}), 2.12(\mathrm{~m}, 1 \mathrm{H}), 1.85$ (dq, $J=13.3$, $4.5 \mathrm{~Hz}, 1 \mathrm{H}), 1.61(\mathrm{dtd}, J=13.1,11.5,4.5 \mathrm{~Hz}, 1 \mathrm{H}) ;{ }^{13} \mathbf{C} \mathbf{N M R}\left(125 \mathrm{MHz}, \mathrm{CDCl}_{3}\right): \delta 211.3,137.4$, 
134.2, 130.4, 128.7, 128.1, 126.5, 82.2, 78.6, 37.9, 35.7, 28.7, 26.0, 25.4; HRMS $\left(\mathrm{ESI}^{+}\right):[\mathrm{M}+\mathrm{H}]^{+}$ calculated for $\left[\mathrm{C}_{14} \mathrm{H}_{17} \mathrm{O}_{2}\right]^{+}$required $217.1223 \mathrm{~m} / \mathrm{z}$, found $217.1221 \mathrm{~m} / \mathrm{z}$.

$\underline{\text { S64-Minor: }}$

IR (ATR): $v$ 3022.6, 2925.8, 2856.7, 1715.6, 1353.5, $1072.6 \mathrm{~cm}^{-1} ;{ }^{1} \mathbf{H} \mathbf{~ N M R}\left(500 \mathrm{MHz}, \mathrm{CDCl}_{3}\right)$ : $\delta$ 7.50-7.42 (m, $1 \mathrm{H}), 7.25-7.20(\mathrm{~m}, 2 \mathrm{H}), 7.17-7.10(\mathrm{~m}, 1 \mathrm{H}), 4.85(\mathrm{~d}, J=5.8 \mathrm{~Hz}, 1 \mathrm{H}), 4.36(\mathrm{dd}$, $J=8.5,7.3 \mathrm{~Hz}, 1 \mathrm{H}), 2.78(\mathrm{dt}, J=16.3,4.8 \mathrm{~Hz}, 1 \mathrm{H}), 2.67(\mathrm{ddd}, J=16.0,10.6,4.5 \mathrm{~Hz}, 1 \mathrm{H}) ; 2.57-$ $2.46(\mathrm{~m}, 2 \mathrm{H}), 2.13(\mathrm{~s}, 3 \mathrm{H}), 1.87-1.78(\mathrm{~m}, 2 \mathrm{H}), 1.54-1.45(\mathrm{~m}, 1 \mathrm{H}) ;{ }^{13} \mathbf{C ~ N M R}\left(125 \mathrm{MHz}, \mathrm{CDCl}_{3}\right)$ : $\delta$ 210.6, 137.7, 134.5, 130.6, 128.5, 127.9, 126.4, 83.3, 78.8, 37.2, 35.6, 28.5, 26.4, 26.1; HRMS $\left(\mathrm{ESI}^{+}\right):[\mathrm{M}+\mathrm{H}]^{+}$calculated for $\left[\mathrm{C}_{14} \mathrm{H}_{17} \mathrm{O}_{2}\right]^{+}$required $217.1223 \mathrm{~m} / \mathrm{z}$, found $217.1220 \mathrm{~m} / \mathrm{z}$.

2,5,5-Trimethyl-3-methylene-1-tosylpiperidine (Table 2, 28). Synthesized according to the

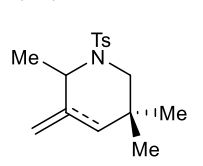
general procedure using $\mathbf{S 4 3}(0.088 \mathrm{~g}, 0.30 \mathrm{mmol}), \mathbf{C u}(\mathrm{EH})_{2}(0.210 \mathrm{~g}, 0.600 \mathrm{mmol})$, TFA $(0.023 \mathrm{~mL}, 0.30 \mathrm{mmol})$, and $\operatorname{MesAcrMe}^{+}(0.0036 \mathrm{~g}, 0.0075 \mathrm{mmol})$ and irradiating for $16 \mathrm{~h}$. After chromatography on $\mathrm{SiO}_{2}$ (10\% EtOAc in hexanes), the products were isolated as an opaque yellow oil ( $0.081 \mathrm{~g}, 0.28 \mathrm{mmol}, 93 \%, 4: 1$ r.r.). Analytically pure samples of the major regioisomer could be obtained via chromatography on $\mathrm{SiO}_{2}$ (10\% EtOAc in hexanes).

IR (ATR): $v$ 2957.7, 2928.4, 2867.7, 1779.0, $1335.9 \mathrm{~cm}^{-1} ;{ }^{1} \mathbf{H}$ NMR $\left(500 \mathrm{MHz}, \mathrm{CDCl}_{3}\right): \delta 7.71-$ $7.65(\mathrm{~m}, 2 \mathrm{H}), 7.29-7.23(\mathrm{~m}, 2 \mathrm{H}), 4.87(\mathrm{t}, J=1.8 \mathrm{~Hz}, 1 \mathrm{H}), 4.65(\mathrm{t}, J=1.9 \mathrm{~Hz}, 1 \mathrm{H}), 4.62(\mathrm{q}, J=$ $6.9 \mathrm{~Hz}, 1 \mathrm{H}), 3.27(\mathrm{dd}, J=12.8,1.6 \mathrm{~Hz}, 1 \mathrm{H}), 2.83(\mathrm{~d}, J=12.8 \mathrm{~Hz}, 1 \mathrm{H}), 2.41(\mathrm{~s}, 3 \mathrm{H}), 2.15(\mathrm{dd}, J$ $=13.6,2.0 \mathrm{~Hz}, 1 \mathrm{H}), 1.81(\mathrm{dd}, J=13.6,2.1 \mathrm{~Hz}, 1 \mathrm{H}), 1.10(\mathrm{~d}, J=6.9 \mathrm{~Hz}, 3 \mathrm{H}), 0.94(\mathrm{~s}, 3 \mathrm{H}), 0.74$ (s, $3 \mathrm{H}) ;{ }^{13} \mathrm{C} \mathrm{NMR}\left(125 \mathrm{MHz}, \mathrm{CDCl}_{3}\right): \delta 144.3,143.0,138.5,129.6,127.2,111.0,55.3,50.7,42.3$, 32.7, 28.1, 23.6, 21.6, 16.6; HRMS $\left(\mathrm{ESI}^{+}\right):[\mathrm{M}+\mathrm{H}]^{+}$calculated for $\left[\mathrm{C}_{16} \mathrm{H}_{24} \mathrm{NO}_{2} \mathrm{~S}\right]^{+}$required $294.1522 \mathrm{~m} / \mathrm{z}$, found $294.1519 \mathrm{~m} / \mathrm{z}$.

2-(3,6-Dihydro-2H-pyran-4-yl)-1-tosylpyrrolidine (Table 2, 29). Synthesized according to the

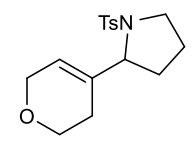
general procedure using $\mathbf{S} 49(0.092 \mathrm{~g}, 0.30 \mathrm{mmol}), \mathbf{C u}(\mathrm{EH})_{2}(0.210 \mathrm{~g}, 0.600 \mathrm{mmol})$, TFA $(0.023 \mathrm{~mL}, 0.30 \mathrm{mmol})$, and $\operatorname{MesAcrMe}^{+}(0.0036 \mathrm{~g}, 0.0075 \mathrm{mmol})$ and irradiating for $16 \mathrm{~h}$. After chromatography on $\mathrm{SiO}_{2}\left(50-60 \% \mathrm{Et}_{2} \mathrm{O}\right.$ in hexanes), 29 was isolated as a white solid $(0.051 \mathrm{~g}, 0.17 \mathrm{mmol}, 56 \%)$.

IR (ATR): v 2920.8, 2855.1, 2805.3, 2756.0, $1337.7,1157.0 \mathrm{~cm}^{-1} ;{ }^{1} \mathbf{H}$ NMR (500 MHz, $\left.\mathrm{CDCl}_{3}\right)$ : $\delta 7.71(\mathrm{~d}, J=8.3 \mathrm{~Hz}, 2 \mathrm{H}), 7.31(\mathrm{~d}, J=8.0 \mathrm{~Hz}, 2 \mathrm{H}), 5.70-5.66(\mathrm{~m}, 1 \mathrm{H}), 4.14(\mathrm{qd}, J=2.6,1.2 \mathrm{~Hz}$, $2 \mathrm{H}$ ), 4.05 (dd, $J=7.9,4.7 \mathrm{~Hz}, 1 \mathrm{H}), 3.80(\mathrm{dt}, J=10.7,5.2 \mathrm{~Hz}, 1 \mathrm{H}$ ), 3.66 (ddd, $J=11.1,6.7,4.6$ $\mathrm{Hz}, 1 \mathrm{H}), 3.44$ (ddd, $J=10.2,7.2,5.1 \mathrm{~Hz}, 1 \mathrm{H}), 3.32(\mathrm{dt}, J=10.2,7.2 \mathrm{~Hz}, 1 \mathrm{H}), 2.43(\mathrm{~s}, 3 \mathrm{H})$, 2.14-1.97 (m, $2 \mathrm{H}), 1.85-1.64(\mathrm{~m}, 3 \mathrm{H}), 1.64-1.57(\mathrm{~m}, 1 \mathrm{H}) ;{ }^{13} \mathbf{C}$ NMR $\left(125 \mathrm{MHz}, \mathrm{CDCl}_{3}\right): \delta$ 143.3, 135.4, 135.4, 129.7, 127.7, 122.0, 65.5, 64.6, 64.1, 49.3, 31.2, 25.1, 24.2, 21.7; HRMS $\left(\mathrm{ESI}^{+}\right):[\mathrm{M}+\mathrm{H}]^{+}$calculated for $\left[\mathrm{C}_{16} \mathrm{H}_{22} \mathrm{NO}_{3} \mathrm{~S}\right]^{+}$required $308.1315 \mathrm{~m} / \mathrm{z}$, found $308.1310 \mathrm{~m} / \mathrm{z}$.

2-(1-Phenylvinyl)-1-tosylpyrrolidine (Table 2, 30). Synthesized according to the general Ts procedure using $\mathbf{S 5 2}(0.98 \mathrm{~g}, 0.30 \mathrm{mmol}), \mathbf{C u}(\mathrm{EH})_{2}(0.212 \mathrm{~g}, 0.606 \mathrm{mmol}), \mathrm{TsOH} \cdot \mathrm{H}_{2} \mathrm{O}$ $(0.057 \mathrm{~mL}, 0.30 \mathrm{mmol})$, and MesAcrMe ${ }^{+}(0.0036 \mathrm{~g}, 0.0075 \mathrm{mmol})$ and irradiating for 
30 min. After chromatography on $\mathrm{SiO}_{2}(10-20 \%$ EtOAc in hexanes), 30 was isolated as a yellow oil (0.066 g, $0.20 \mathrm{mmol}, 68 \%)$.

IR (ATR): $v$ 3055.0, 2973.3, 2875.3, 1597.2, 1342.9, $1158.0 \mathrm{~cm}^{-1} ;{ }^{1} \mathbf{H}$ NMR $\left(500 \mathrm{MHz}, \mathrm{CDCl}_{3}\right)$ : $\delta 7.78(\mathrm{~d}, J=8.2 \mathrm{~Hz}, 2 \mathrm{H}), 7.40-7.24(\mathrm{~m}, 7 \mathrm{H}), 5.38(\mathrm{~s}, 1 \mathrm{H}), 5.34(\mathrm{~s}, 1 \mathrm{H}), 4.75(\mathrm{dd}, J=7.8,3.1$ Hz, $1 \mathrm{H}$ ), 3.53 (ddd, $J=10.2,7.4,2.9 \mathrm{~Hz}, 1 \mathrm{H}), 3.29$ (td, $J=9.5,6.4 \mathrm{~Hz}, 1 \mathrm{H}), 2.44$ (s, $3 \mathrm{H}), 1.87-$ $1.73(\mathrm{~m}, 1 \mathrm{H}), 1.68-1.53(\mathrm{~m}, 3 \mathrm{H}) ;{ }^{13} \mathrm{C}$ NMR $\left(125 \mathrm{MHz}, \mathrm{CDCl}_{3}\right): \delta 149.0,143.5,140.0,135.4$, $129.8,128.5,127.8,127.7,127.1,114.0,63.1,49.1,32.0,23.7,21.7$; HRMS $\left(\mathrm{ESI}^{+}\right):[\mathrm{M}+\mathrm{H}]^{+}$ calculated for $\left[\mathrm{C}_{19} \mathrm{H}_{22} \mathrm{NO}_{2} \mathrm{~S}\right]^{+}$required $328.1366 \mathrm{~m} / \mathrm{z}$, found $328.1364 \mathrm{~m} / \mathrm{z}$.

11-Methyl-11-(prop-1-en-2-yl)-10-tosyl-1,4-dioxa-10-azadispiro[4.2.4 $\left.{ }^{8} .^{5}\right]$ tetradecane (Table

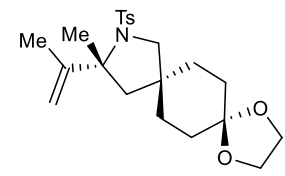
2, 31). Synthesized according to the general procedure using $\mathbf{S 5 6}(0.121 \mathrm{~g}, 0.297$ $\mathrm{mmol}), \mathrm{Cu}(\mathrm{EH})_{2}(0.210 \mathrm{~g}, 0.600 \mathrm{mmol})$, TFA $(0.023 \mathrm{~mL}, 0.30 \mathrm{mmol})$, and $\operatorname{MesAcrMe}^{+}(0.0036 \mathrm{~g}, 0.0075 \mathrm{mmol})$ and irradiating for $42 \mathrm{~h}$. After chromatography on $\mathrm{SiO}_{2}\left(35-40 \% \mathrm{Et}_{2} \mathrm{O}\right.$ in hexanes), 31 was isolated as a white solid $(0.072 \mathrm{~g}, 0.18 \mathrm{mmol}, 60 \%)$.

Mp 130-132 ${ }^{\circ} \mathrm{C}$; IR (ATR): v 2941.5, 2866.6, 1447.1, 1373.5, $1155.0 \mathrm{~cm}^{-1} ;{ }^{\mathbf{1}} \mathbf{H}$ NMR (500 MHz, $\left.\mathrm{CDCl}_{3}\right): \delta$ 7.76-7.71 (m, $\left.2 \mathrm{H}\right), 7.29-7.24(\mathrm{~m}, 2 \mathrm{H}), 5.08(\mathrm{~s}, 1 \mathrm{H}), 4.88(\mathrm{t}, J=1.4 \mathrm{~Hz}, 1 \mathrm{H}), 3.90$ (app. s, $4 \mathrm{H}), 3.35(\mathrm{ABq}, J=10.1 \mathrm{~Hz}, 1 \mathrm{H}), 3.27(\mathrm{ABq}, J=10.1 \mathrm{~Hz}, 1 \mathrm{H}), 2.41(\mathrm{~s}, 3 \mathrm{H}), 1.99(\mathrm{ABq}$, $J=13.4 \mathrm{~Hz}, 1 \mathrm{H}), 1.81(\mathrm{~s}, 3 \mathrm{H}), 1.66(\mathrm{ABq}, J=13.4 \mathrm{~Hz}, 1 \mathrm{H}), 1.63(\mathrm{~s}, 3 \mathrm{H}), 1.63-1.40(\mathrm{~m}, 8 \mathrm{H})$; ${ }^{13} \mathrm{C}$ NMR $\left(125 \mathrm{MHz}, \mathrm{CDCl}_{3}\right): \delta 149.6,142.9,138.4,129.5,127.4,111.0,108.3,70.5,64.4,64.4$, 59.1, 52.0, 39.5, 34.1, 33.9, 32.3, 32.1, 25.8, 21.6, 19.8; HRMS $\left(\mathrm{ESI}^{+}\right):[\mathrm{M}+\mathrm{H}]^{+}$calculated for $\left[\mathrm{C}_{22} \mathrm{H}_{32} \mathrm{NO}_{4} \mathrm{~S}\right]^{+}$required $406.2047 \mathrm{~m} / \mathrm{z}$, found $406.2045 \mathrm{~m} / \mathrm{z}$.

3-Methyl-3-(prop-1-en-2-yl)-2-oxaspiro[4.5]decan-1-one (Table 2, 32) Synthesized according Me ${ }^{\mathrm{Me}}{ }^{\circ}=0$ to the general procedure using $\mathbf{S 5 8}(0.063 \mathrm{~g}, 0.300 \mathrm{mmol}), \mathrm{Cu}(\mathrm{EH})_{2}(0.210 \mathrm{~g}, 0.600$ $\mathrm{mmol})$, TFA $(0.023 \mathrm{~mL}, 0.30 \mathrm{mmol})$, and MesAcrMe ${ }^{+}(0.0036 \mathrm{~g}, 0.0075 \mathrm{mmol})$ and irradiating for $18 \mathrm{~h}$. After chromatography on $\mathrm{SiO}_{2}\left(5-10 \% \mathrm{Et}_{2} \mathrm{O}\right.$ in pentanes), 32 was isolated as a pale yellow oil $(0.063 \mathrm{~g}, 0.30 \mathrm{mmol}, 100 \%)$.

IR (ATR): $v$ 2932.3, 2858.2, 1762.9, 1447.8, $1226.8 \mathrm{~cm}^{-1} ;{ }^{\mathbf{1}} \mathbf{H}$ NMR (500 MHz, $\left.\mathrm{CDCl}_{3}\right): \delta 5.06$ $(\mathrm{m}, 1 \mathrm{H}), 4.85-4.82(\mathrm{~m}, 1 \mathrm{H}), 2.37(\mathrm{~d}, J=13.3 \mathrm{~Hz}, 1 \mathrm{H}), 1.93(\mathrm{~d}, J=13.2 \mathrm{~Hz}, 1 \mathrm{H}), 1.84-1.73(\mathrm{~m}$, $5 \mathrm{H}), 1.73-1.67(\mathrm{~m}, 1 \mathrm{H}), 1.66-1.53(\mathrm{~m}, 4 \mathrm{H}), 1.52(\mathrm{~s}, 3 \mathrm{H}), 1.32-1.24(\mathrm{~m}, 3 \mathrm{H}) ;{ }^{13} \mathrm{C}$ NMR $(125$ $\left.\mathrm{MHz}, \mathrm{CDCl}_{3}\right): \delta 181.5,147.9,110.3,84.6,45.6,43.4,35.5,34.0,28.4,25.2,22.3,22.2,19.0$; HRMS $\left(\mathrm{ESI}^{+}\right)$: $[\mathrm{M}+\mathrm{H}]^{+}$calculated for $\left[\mathrm{C}_{13} \mathrm{H}_{21} \mathrm{O}_{2}\right]^{+}$required $209.1536 \mathrm{~m} / \mathrm{z}$, found $209.1536 \mathrm{~m} / \mathrm{z}$.

3-Methyl-3-(prop-1-en-2-yl)-8-tosyl-2-oxa-8-azaspiro[4.5]decane (Table 2, 33). Synthesized

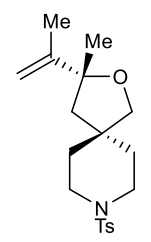

33-Major

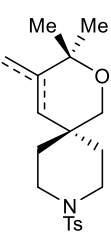

33-Minor according to the general procedure using $\mathbf{S 6 2}(0.115 \mathrm{~g}, 0.33 \mathrm{mmol}), \mathrm{Cu}(\mathrm{EH})_{2}$ $(0.209 \mathrm{~g}, 0.60 \mathrm{mmol}), \mathrm{TsOH} \cdot \mathrm{H}_{2} \mathrm{O}(0.115 \mathrm{~g}, 0.60 \mathrm{mmol})$, and $\mathrm{MesAcrMe}^{+}$ $(0.0036 \mathrm{~g}, 0.0075 \mathrm{mmol})$ and irradiating for $16 \mathrm{~h}$. After chromatography on $\mathrm{SiO}_{2}$ (15\% EtOAc in hexanes), $\mathbf{3 3}$ was isolated as a white solid as a mixture of isomers $(0.095 \mathrm{~g}, 0.27 \mathrm{mmol}, 83 \%, 4: 1$ r.r.). Analytically pure samples of the in hexanes). 
Mp 120-124 ${ }^{\circ} \mathrm{C}$; IR (ATR): v 2973.3, 2920.5, 2845.7, 1441.9, 1335.0, $1159.1 \mathrm{~cm}^{-1}$; ${ }^{1} \mathbf{H}$ NMR $\left(500 \mathrm{MHz}, \mathrm{CDCl}_{3}\right): \delta 7.63(\mathrm{~d}, J=8.2 \mathrm{~Hz}, 2 \mathrm{H}), 7.33(\mathrm{~d}, J=7.9 \mathrm{~Hz}, 2 \mathrm{H}), 4.97-4.92(\mathrm{~m}, 1 \mathrm{H}), 4.71$ (app. P, $J=1.5 \mathrm{~Hz}, 1 \mathrm{H}), 3.58(\mathrm{~d}, J=8.9 \mathrm{~Hz}, 1 \mathrm{H}), 3.48(\mathrm{~d}, J=8.9 \mathrm{~Hz}, 1 \mathrm{H}), 3.05-2.83(\mathrm{~m}, 4 \mathrm{H})$, $2.44(\mathrm{~s}, 3 \mathrm{H}), 1.87(\mathrm{~d}, J=12.9 \mathrm{~Hz}, 1 \mathrm{H}), 1.74-1.68(\mathrm{~m}, 5 \mathrm{H}), 1.64(\mathrm{t}, J=5.7 \mathrm{~Hz}, 2 \mathrm{H}), 1.49(\mathrm{~d}, J=$ $12.9 \mathrm{~Hz}, 1 \mathrm{H}), 1.29$ (s, $3 \mathrm{H}) ;{ }^{3} \mathbf{C}$ NMR $\left(125 \mathrm{MHz}, \mathrm{CDCl}_{3}\right): \delta 149.5,143.6,133.4,129.8,127.8$, 108.8, 85.3, 75.9, 47.9, 44.2, 44.2, 42.4, 35.9, 35.0, 27.8, 21.7, 19.3; HRMS $\left(\mathrm{ESI}^{+}\right):[\mathrm{M}+\mathrm{H}]^{+}$ calculated for $\left[\mathrm{C}_{19} \mathrm{H}_{28} \mathrm{NO}_{3} \mathrm{~S}\right]^{+}$required $350.1784 \mathrm{~m} / \mathrm{z}$, found $350.1781 \mathrm{~m} / \mathrm{z}$.

V. Assignment of Relative Stereochemistry by selective 1D NOESY

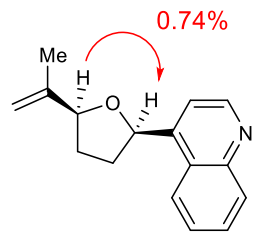

cis-XX

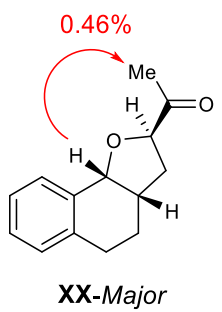

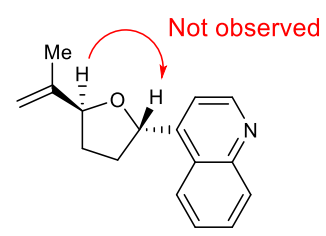

trans-XX

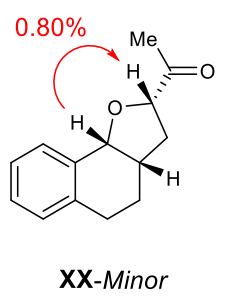




\section{Cyclic Voltammetry Studies}

Cyclic voltammetry experiments were performed in 1,2-DCE with analyte $(1 \mathrm{mM})$ and $[(n$ $\left.\mathrm{Bu})_{4} \mathrm{~N}\right]^{+}\left[\mathrm{PF}_{6}\right]^{-}(100 \mathrm{mM})$ using a glassy carbon working electrode, platinum wire electrode, a $\mathrm{Ag} / \mathrm{AgNO}_{3} \mathrm{MeCN}$ reference electrode, and a scan rate of $50 \mathrm{mV} / \mathrm{s}$. Ferrocene was added as a reference.

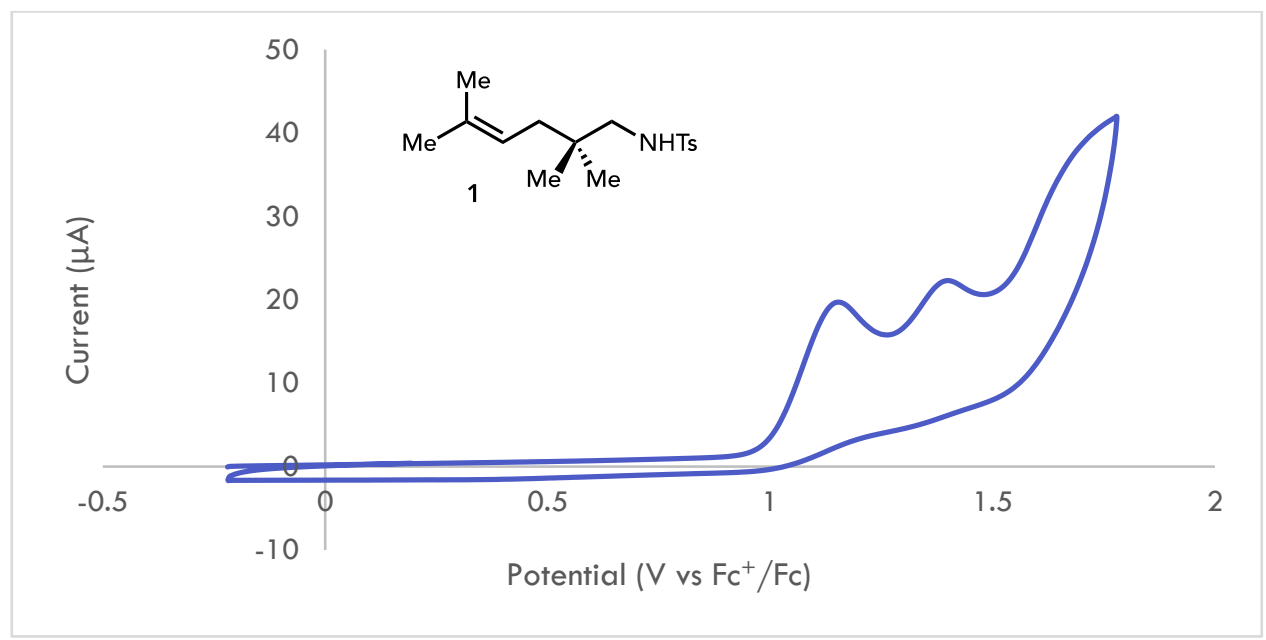

Figure S1. Cyclic voltammogram of alkene 1

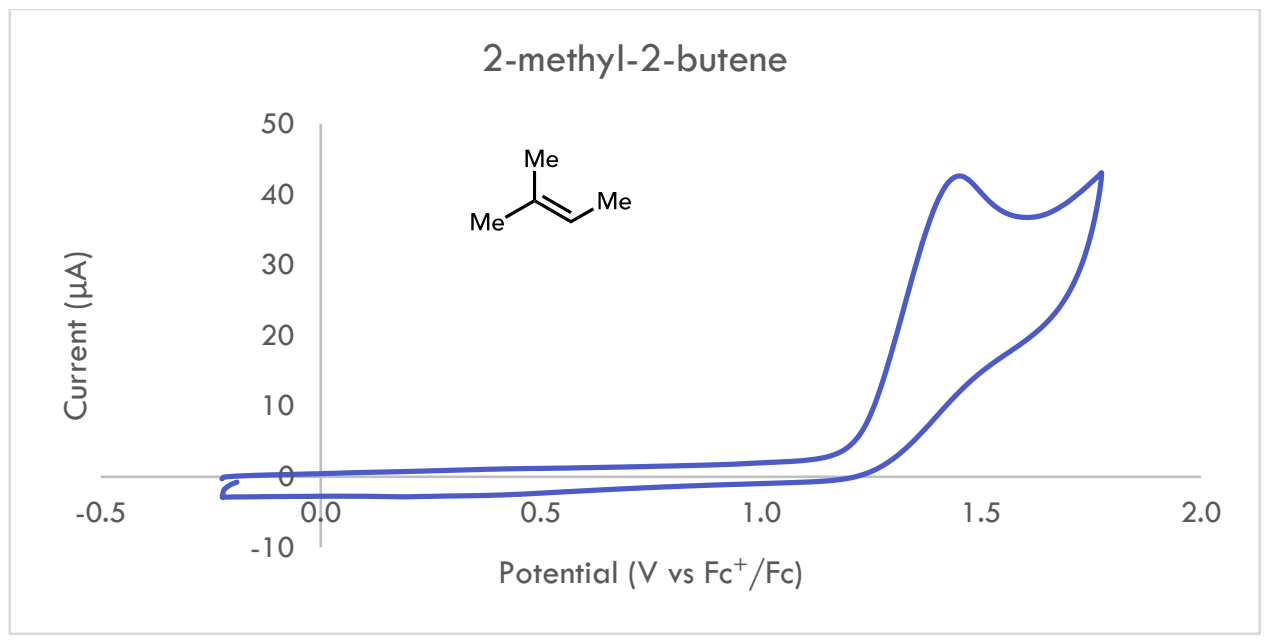

Figure S2. Cyclic voltammogram of 2-methyl-2-butene 


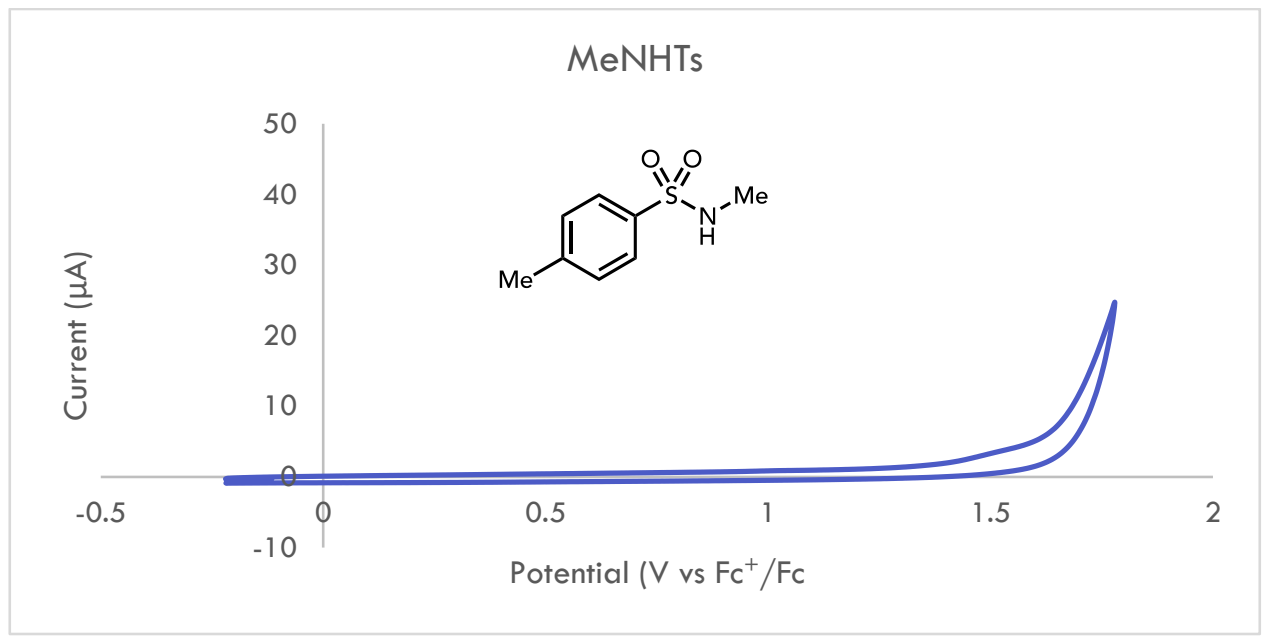

Figure S3. Cyclic voltammogram of MeNHTs

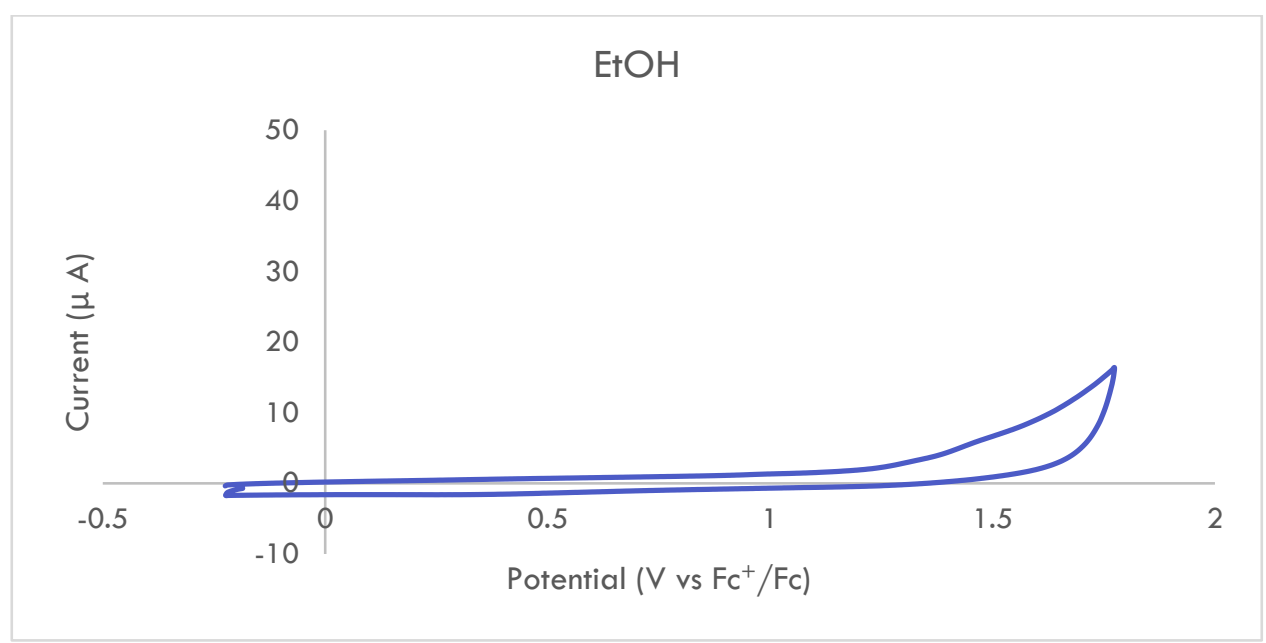

Figure S4. Cyclic voltammogram of EtOH

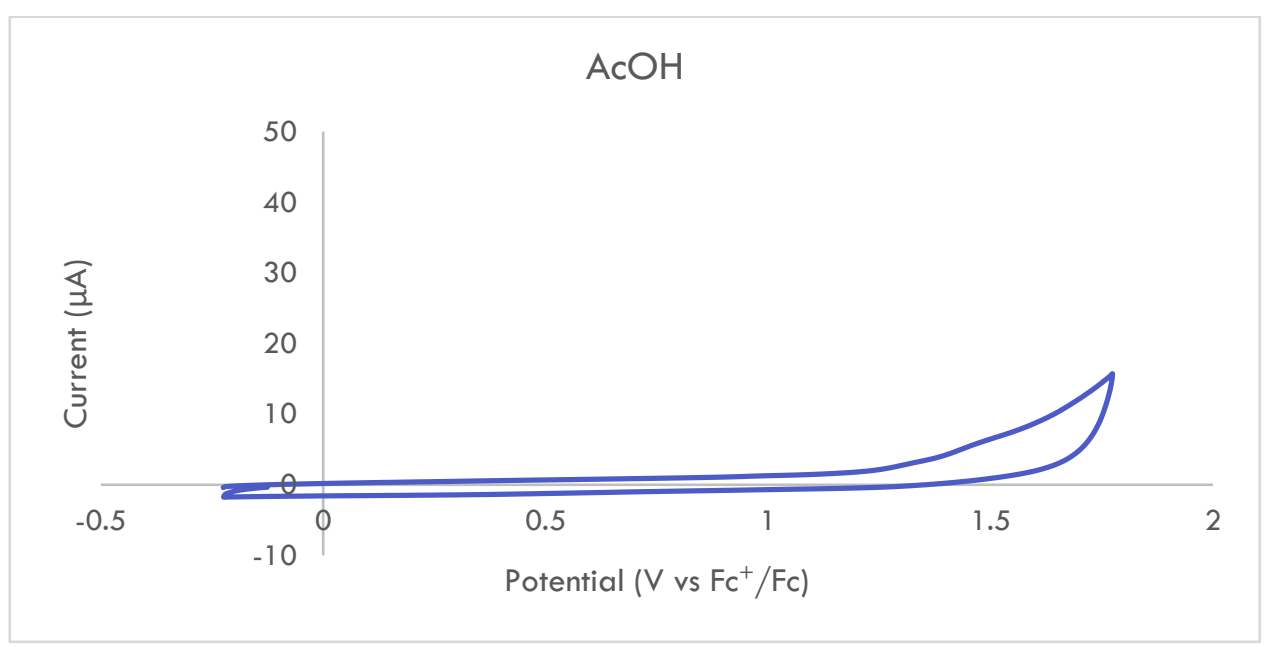

Figure S5. Cyclic voltammogram of $\mathrm{AcOH}$ 


\section{Comparison to Pd(II)-Catalyzed Methods}

Table S2. Oxidative Amination of Highly Substituted Alkenes

A Oxidative Amination of Trisubstituted Alkene 1

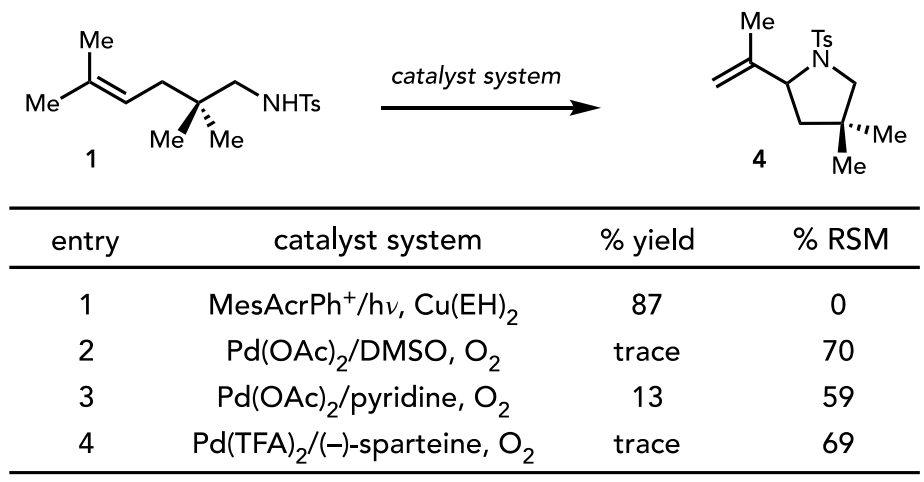

B Oxidative Amination of Tetrasubstituted Alkene 34

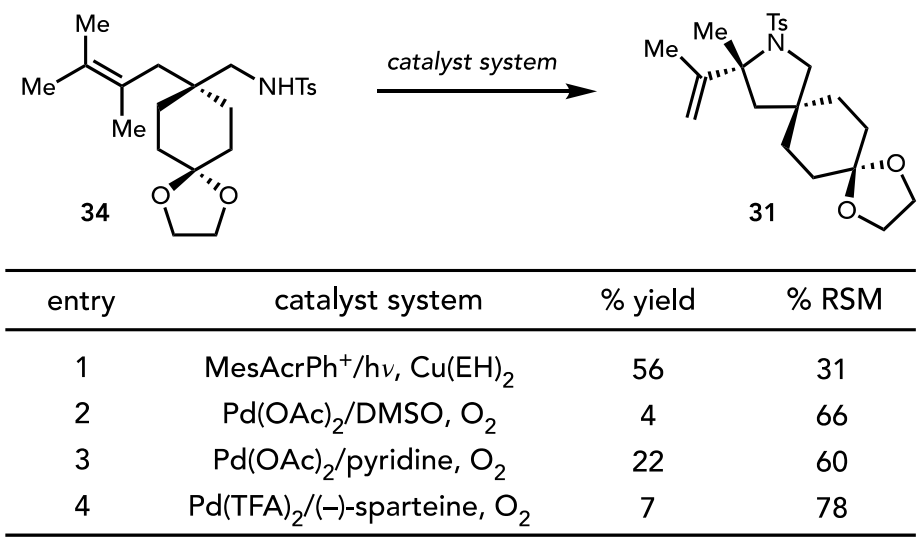

Conditions for Entry 1: A solution of substrate $(0.10 \mathrm{mmol}), \mathrm{Cu}(\mathrm{EH})_{2}(0.070 \mathrm{~g}, 0.20 \mathrm{mmol})$, TFA $(0.007 \mathrm{~mL}, 0.1 \mathrm{mmol})$, and $\mathrm{MesAcrPh}^{+}(0.0025 \mathrm{mmol}, 2.5 \mathrm{~mol} \%)$ in 1,2-DCE $(4 \mathrm{~mL})$ was degassed (freeze-pump-thaw, 3 cycles of 5 min each) and the resulting solution was stirred at rt under irradiation by two $450 \mathrm{~nm}$ blue LED flood lamps for $16 \mathrm{~h}$. The reaction mixture was diluted with $\mathrm{Et}_{2} \mathrm{O}$, eluted through a thin pad of $\mathrm{SiO}_{2}$, and concentrated under reduced pressure to give the crude reaction mixtures. Yields were determined by ${ }^{1} \mathrm{H}$ NMR analysis of the unpurified reaction mixtures using phenanthrene as an internal standard.

Conditions for Entry 2: Adapted from the procedure of Larlock and coworkers. ${ }^{12}$ To a $25 \mathrm{~mL}$ round bottom flask was added the substrate $\left(0.25 \mathrm{mmol}, 1\right.$ equiv), $\mathrm{Pd}(\mathrm{OAc})_{2}(0.0028 \mathrm{~g}, 0.013$ $\mathrm{mmol}), \mathrm{NaOAc}(0.041 \mathrm{~g}, 0.50 \mathrm{mmol})$, DMSO $(5 \mathrm{~mL})$, and a stirbar. The headspace of the flask was purged with $\mathrm{O}_{2}$, equipped with an $\mathrm{O}_{2}$ balloon, and stirred at $\mathrm{rt}$ for $72 \mathrm{~h}$. After $72 \mathrm{~h}$, the reaction mixture was diluted with $\mathrm{Et}_{2} \mathrm{O}$ and THF and transferred to a separatory funnel. The mixture was washed with brine and the aqueous layer was extracted twice with $\mathrm{Et}_{2} \mathrm{O}(20 \mathrm{~mL})$. The combined organic extracts were washed twice with $10 \%$ aqueous $\mathrm{NaCl}$ solution $(20 \mathrm{~mL})$, dried with $\mathrm{MgSO}_{4}$, 
filtered, and concentrated under reduced pressure. The crude reaction mixture was analyzed by ${ }^{1} \mathrm{H}$ NMR using phenanthrene as an internal standard.

Conditions for Entry 3: Adapted from the procedure of Stahl and coworkers. ${ }^{13,14}$ To a 5 mL round bottom flask was added the substrate $(0.10 \mathrm{mmol}, 1$ equiv $)$, pyridine $(0.010 \mathrm{~mL}, 0.010 \mathrm{mmol})$, toluene $(0.5 \mathrm{~mL})$, and a stirbar. The headspace of the flask was purged with $\mathrm{O}_{2}$ and equipped with an $\mathrm{O}_{2}$ balloon. $\mathrm{Pd}(\mathrm{OAc})_{2}(0.0011 \mathrm{~g}, 0.0050 \mathrm{mmol})$ in toluene $(0.5 \mathrm{~mL})$ was added via syringe and the reaction mixture was stirred for $24 \mathrm{~h}$ at $80^{\circ} \mathrm{C}$. After $24 \mathrm{~h}$, the reaction was cooled to rt and the solvent was evaporated under reduced pressure. The mixture was taken up in toluene, filtered through a thin pad of silica and concentrated under reduced pressure. The crude reaction mixture was analyzed by ${ }^{1} \mathrm{H}$ NMR using phenanthrene as an internal standard.

Conditions for Entry 4: Adapted from the procedure of Yang and coworkers. ${ }^{15}$ To a $10 \mathrm{~mL}$ round bottom flask was added $\operatorname{Pd}(\mathrm{TFA})_{2}(0.0067 \mathrm{~g}, 0.020 \mathrm{mmol}),(-)$-sparteine $(0.019 \mathrm{~g}, 0.081 \mathrm{mmol})$, activated $3 \AA$ molecular sieves $(0.50 \mathrm{~g})$, toluene $(1.5 \mathrm{~mL})$ and a stirbar. After the reaction mixture was stirred for $30 \mathrm{~min}$ at $\mathrm{rt}$, the substrate $(0.20 \mathrm{mmol})$ was added followed by diisopropylethylamine $(0.070 \mathrm{~mL}, 0.40 \mathrm{mmol})$. The reaction flask was fitted with a reflux condenser, the headspace purged with $\mathrm{O}_{2}$, equipped with an $\mathrm{O}_{2}$ balloon, and heated to $80{ }^{\circ} \mathrm{C}$. After $26 \mathrm{~h}$, the reaction mixture was cooled to rt, filtered through a small pad of silica with EtOAc, and concentrated under reduced pressure. The crude reaction mixture was analyzed by ${ }^{1} \mathrm{H}$ NMR using phenanthrene as an internal standard.

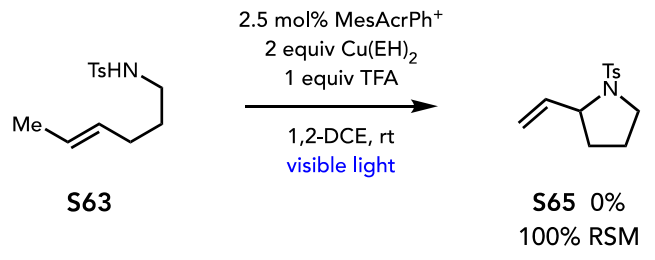

Reaction of Disubstituted Alkene: A solution of $\mathbf{S 6 3}(0.025 \mathrm{~g}, 0.10 \mathrm{mmol}), \mathrm{Cu}(\mathrm{EH})_{2}(0.071 \mathrm{~g}$, $0.20 \mathrm{mmol})$, trifluoroacetic acid $(0.007 \mathrm{~mL}, 0.1 \mathrm{mmol})$, and $\mathrm{MesAcrPh}^{+}(0.0012 \mathrm{~g}, 0.0025 \mathrm{mmol}$, $2.5 \mathrm{~mol} \%$ ) in 1,2-DCE (4 mL) was degassed (freeze-pump-thaw, 3 cycles of $5 \mathrm{~min}$ each) and the resulting solution was stirred at $\mathrm{rt}$ under irradiation by a $450 \mathrm{~nm}$ blue LED flood lamp for $16 \mathrm{~h}$. The reaction mixture was diluted with $\mathrm{Et}_{2} \mathrm{O}$, eluted through a thin pad of $\mathrm{SiO}_{2}$, and concentrated under reduced pressure. ${ }^{1} \mathrm{H}$ NMR analysis of the unpurified reaction mixture using phenanthrene as an internal standard showed 0\% yield of $\mathbf{S 6 5}$ and 100\% remaining $\mathbf{S 6 3 .}$

\section{References}

${ }^{1}$ Pangborn, A. B.; Giardello, M. A.; Grubbs, R. H.; Rosen, R. K.; Timmers, F. J. Organometallics 1996, 15, 1518-1520.

${ }^{2}$ Still, W. C.; Kahn, M.; Mitra, A. J. Org. Chem. 1978, 43, 2923-2925.

${ }^{3}$ Bonilla, P.; Rey, Y. P.; Holden, C. M.; Melchiorre, P. Angew. Chem., Int. Ed. 2018 s7, 1281912823.

${ }^{4}$ Mook, Jr., R.; Sher, P. M. Org. Synth. 1988, 66, 75.

5 Aubineau, T.; Cossy, J. Org. Lett. 2018, 23, 7419-7423. 
${ }^{6}$ Park, O. S.; Lim, J. G. Arch. Pharm. Res. 1996, 19, 581-585.

${ }^{7}$ Venning, A. R. O.; Kwiatkowski, M. R.; Roque Peña, J. E.; Lainhart, B. C.; Guruparan, A. A.; Alexanian, E. J. J. Am. Chem. Soc. 2017, 139, 11595-11600.

${ }^{8}$ Green, S. A.; Huffman, T. R.; McCourt, R. O.; van der Puyl, V.; Shenvi, R. A. J. Am. Chem. Soc. 2019, 141, 7709-7714.

${ }^{9}$ Musacchio, A. J.; Nguyen, L. Q.; Beard, G. H.; Knowles, R. R. J. Am. Chem. Soc. 2014, 136, $12217-12220$.

${ }^{10}$ Kou, X.; Shao, Q.; Ye, C.; Yang, G.; Zhang, W. J. Am. Chem. Soc. 2018, 140, 7587-7597.

${ }^{11}$ Marcotullio, M. C.; Campagna, V.; Sternativo, S.; Constantino, F.; Curini, M. Synthesis 2006, 16, 2760-2766.

${ }^{12}$ Larock, R. C.; Hightower, T., R.; Hasvold, L. A.; Peterson, K. P. J. Org. Chem. 1996, 61, 3584 3585.

${ }^{13}$ Fix, S. R.; Brice, J. L.; Stahl, S. S. Angew. Chem. Int. Ed. 2002, 41, 164-166.

${ }^{14}$ Lui, G.; Stahl, S. S. J. Am. Chem. Soc. 2007, 129, 6328-6335.

${ }^{15}$ Yip, K-T.; Yang, M.; Law, K-L.; Zhu, N-Y.; Yang, D. J. Am. Chem. Soc. 2006, 128, 31303131. 


\section{Spectral Data}
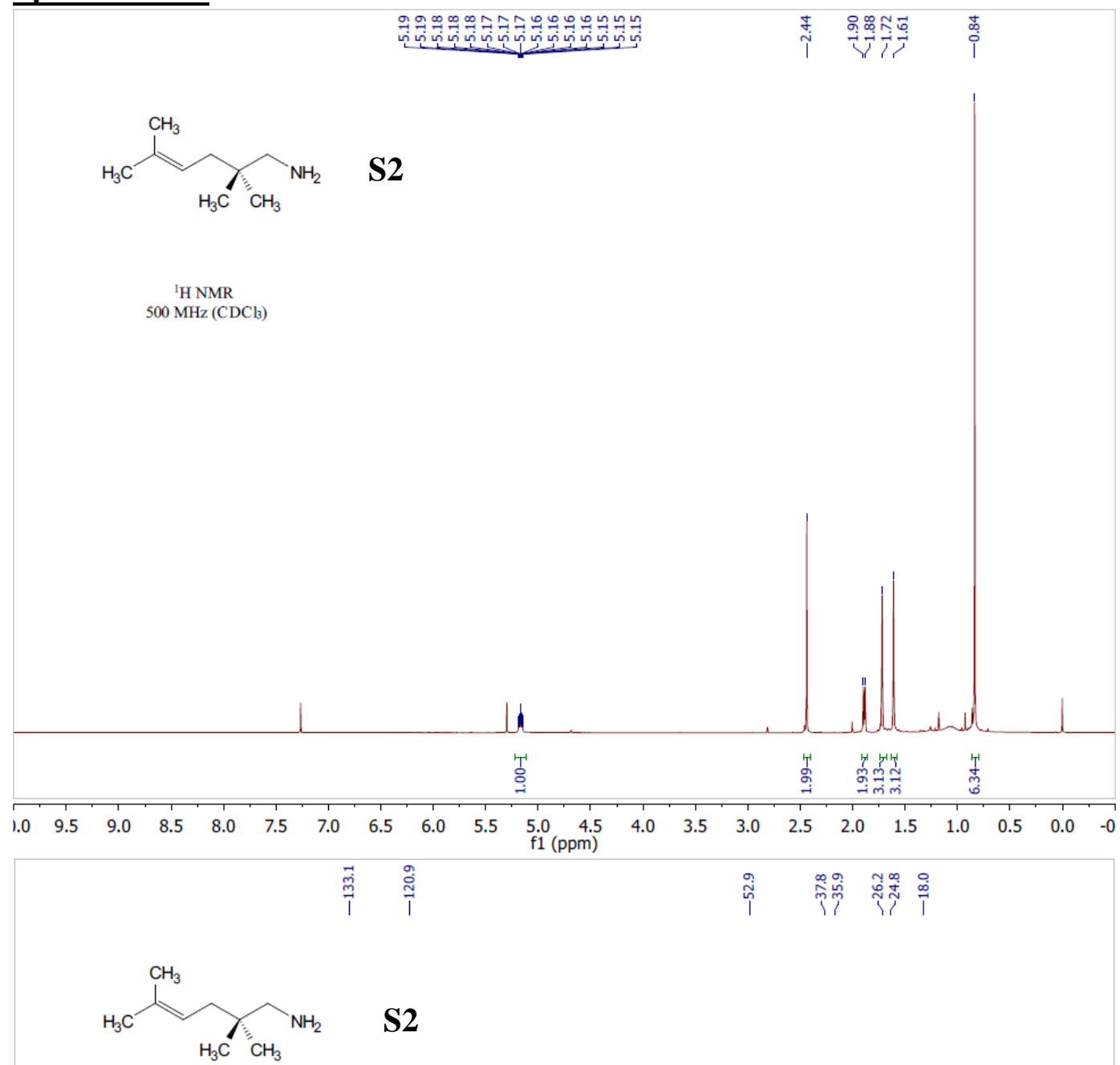

${ }^{13} \mathrm{C}$ NMR

$125 \mathrm{MHz}\left(\mathrm{CDCl}_{3}\right)$

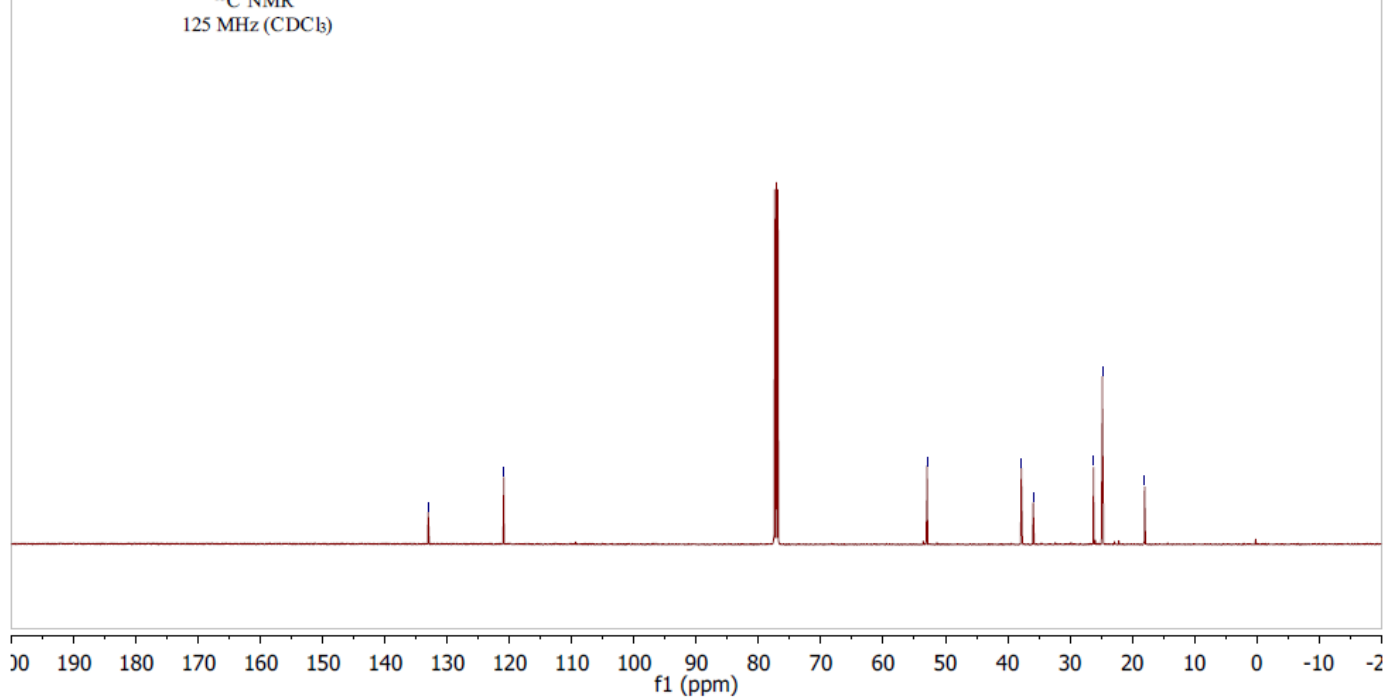




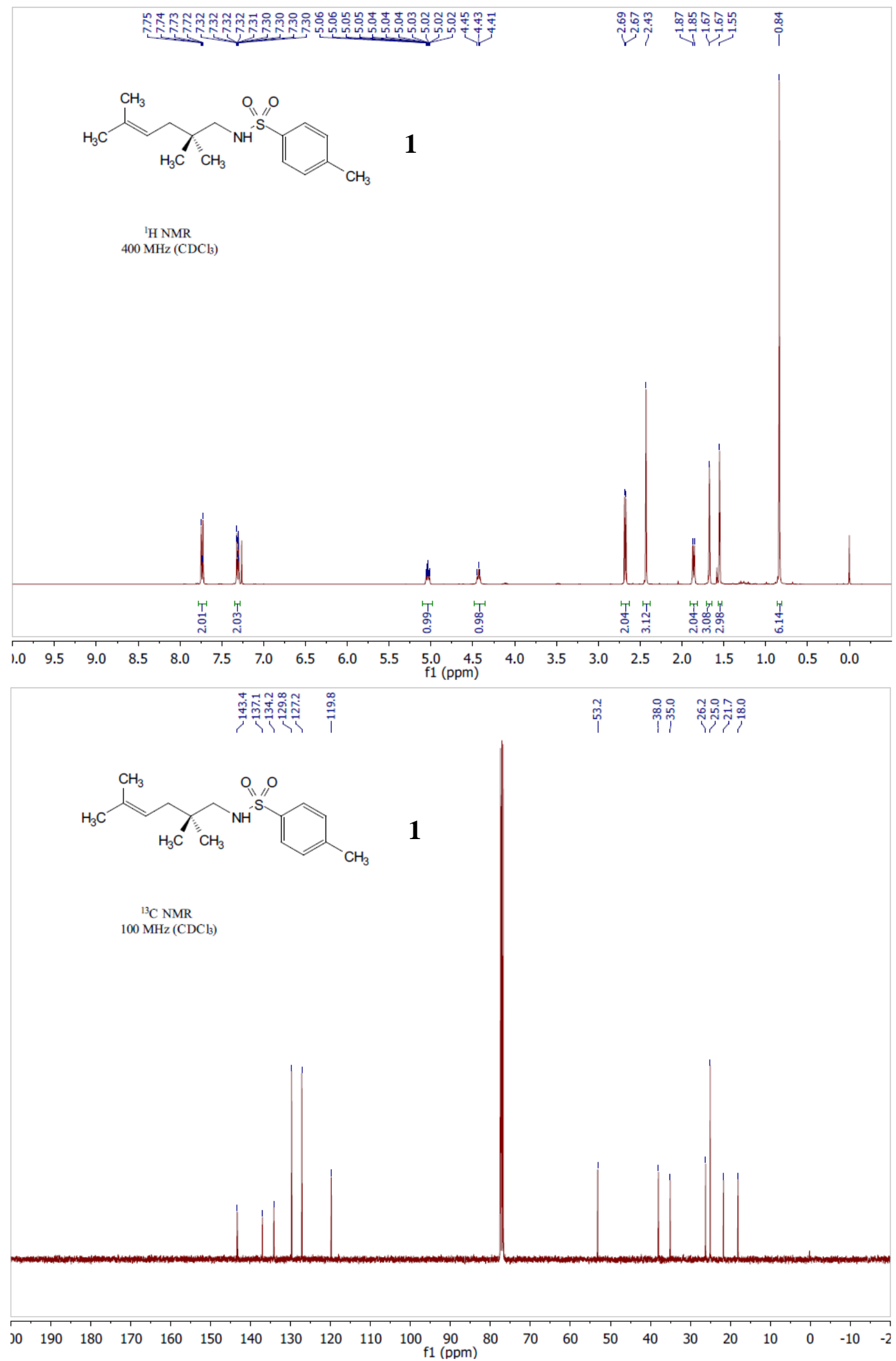




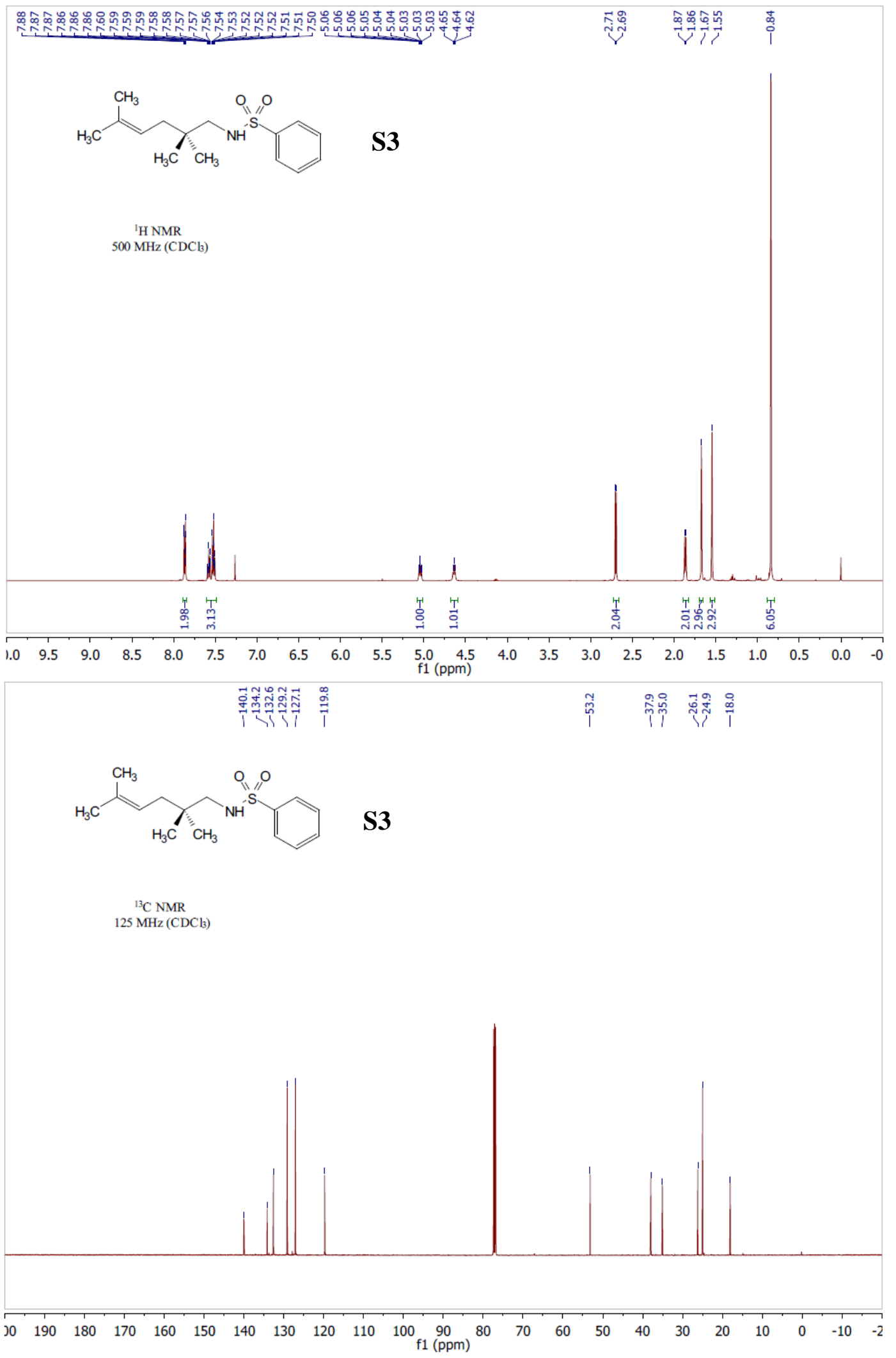

S38 

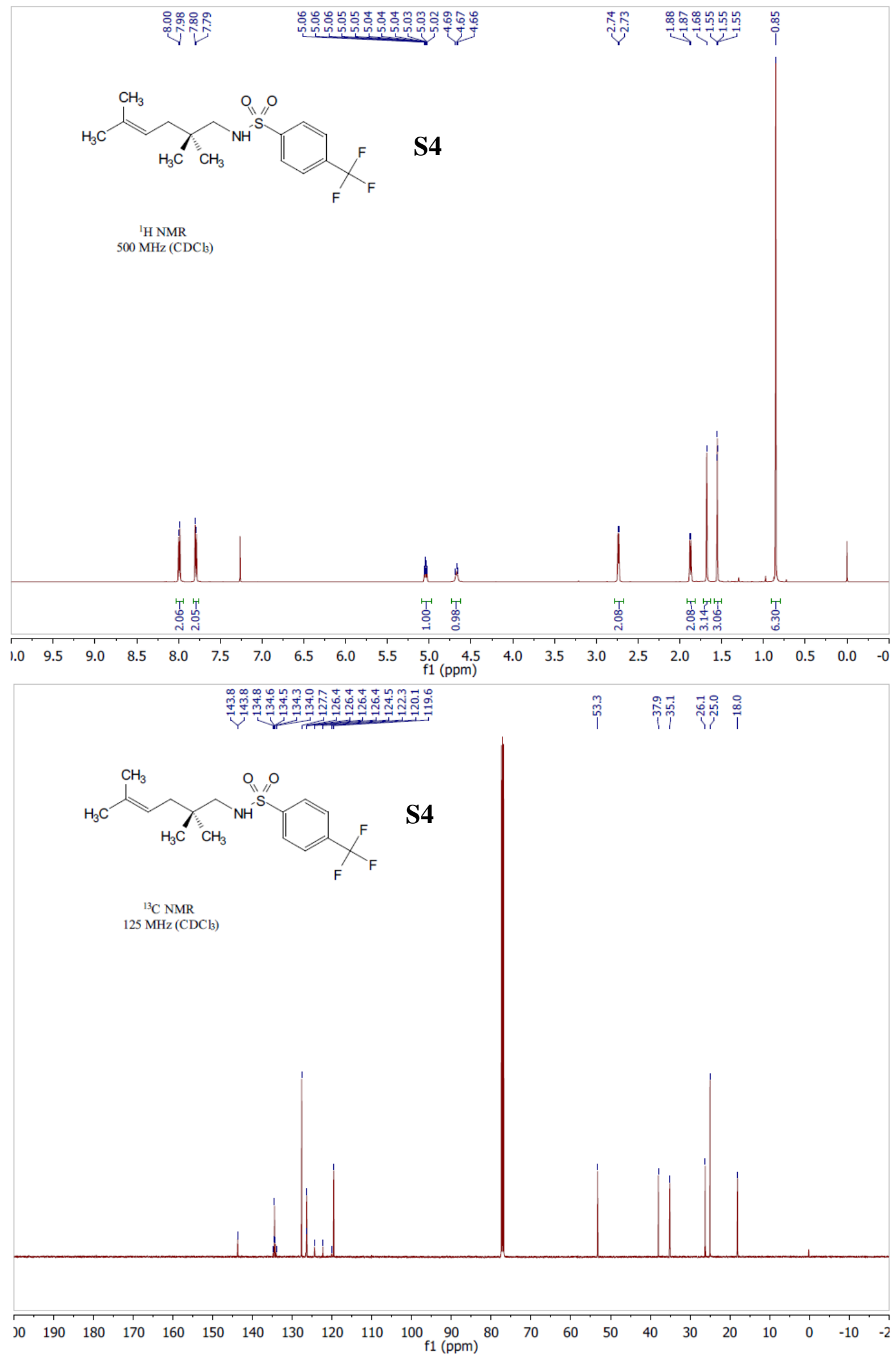

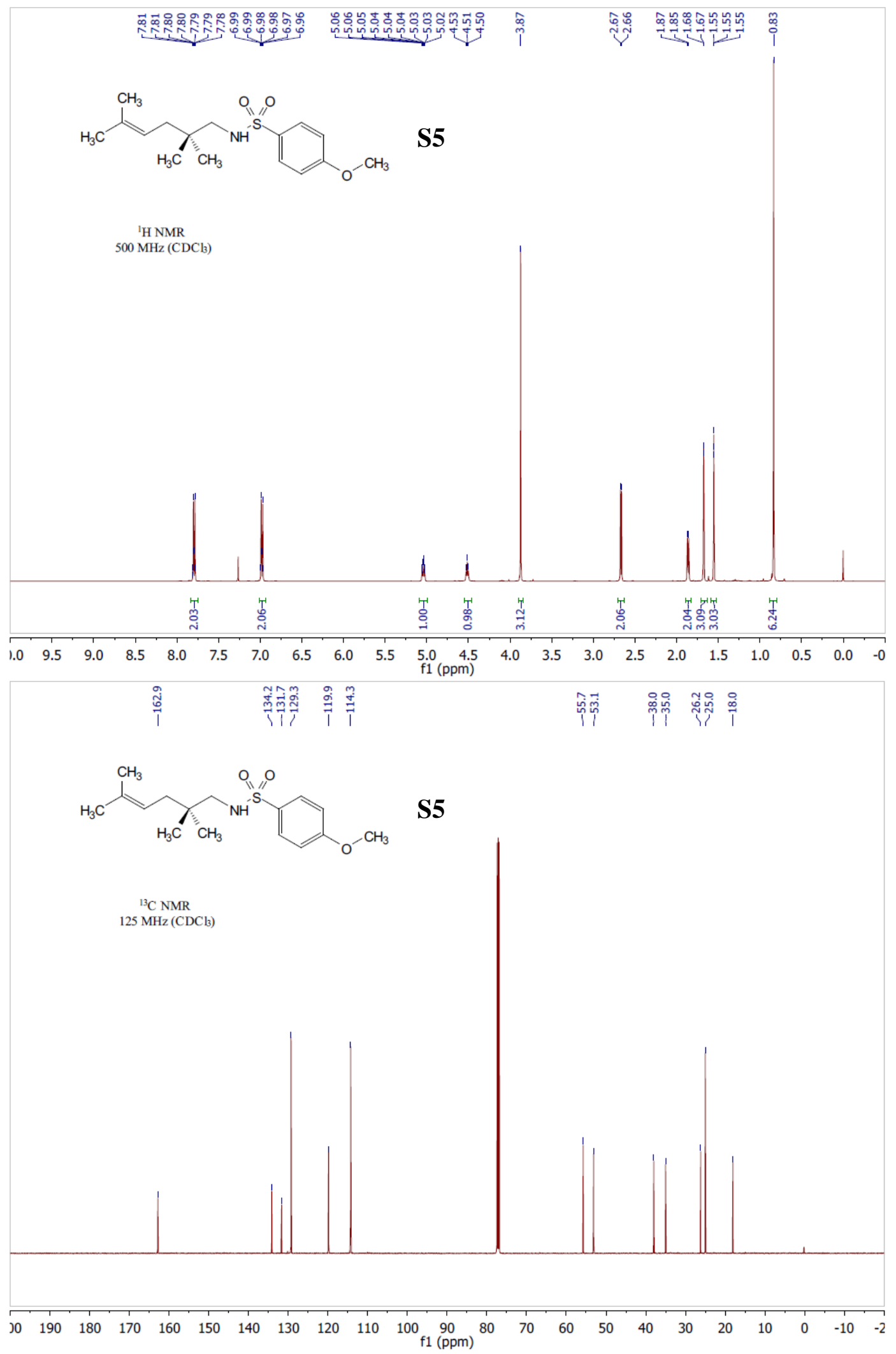

S40 


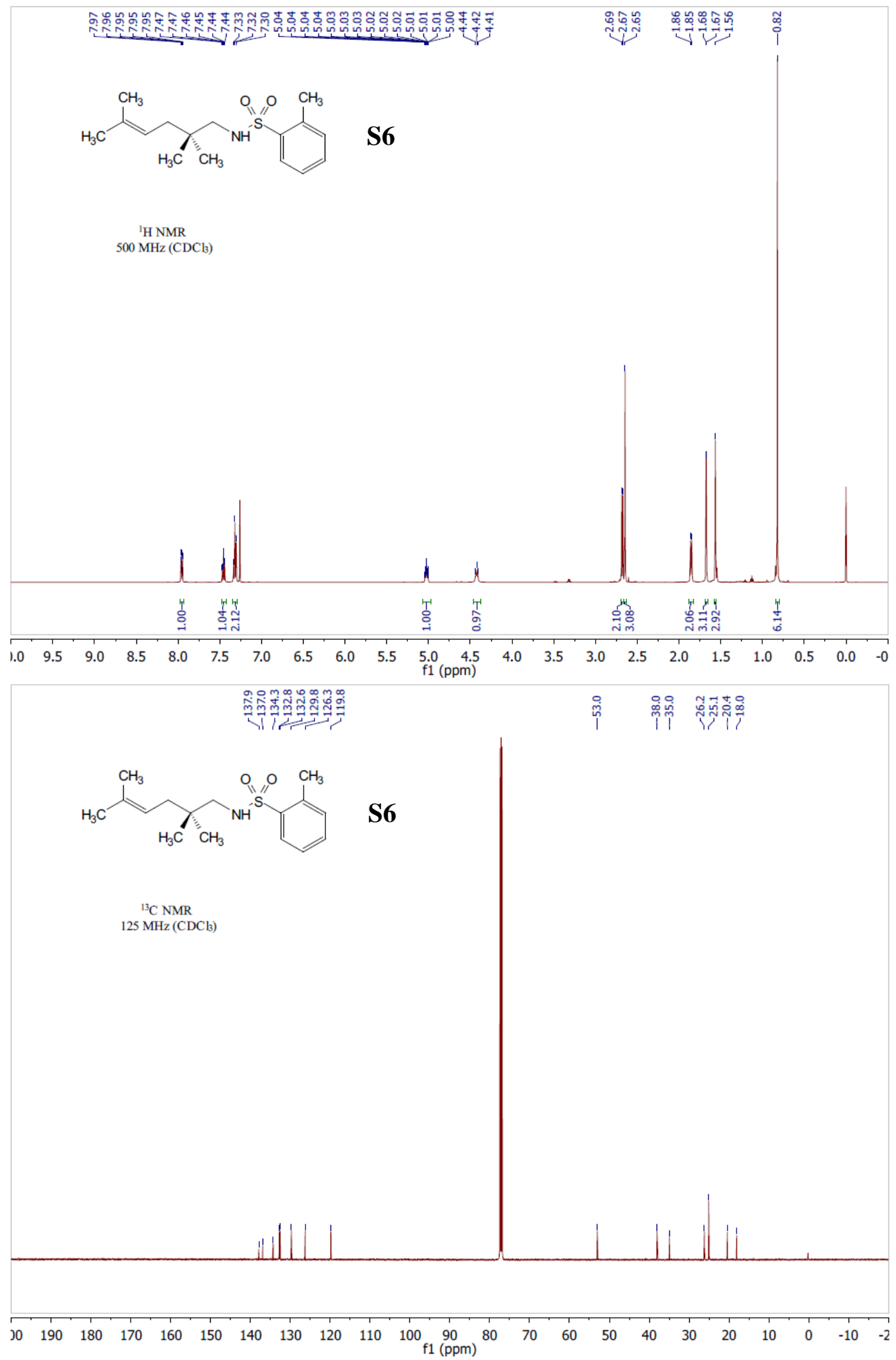




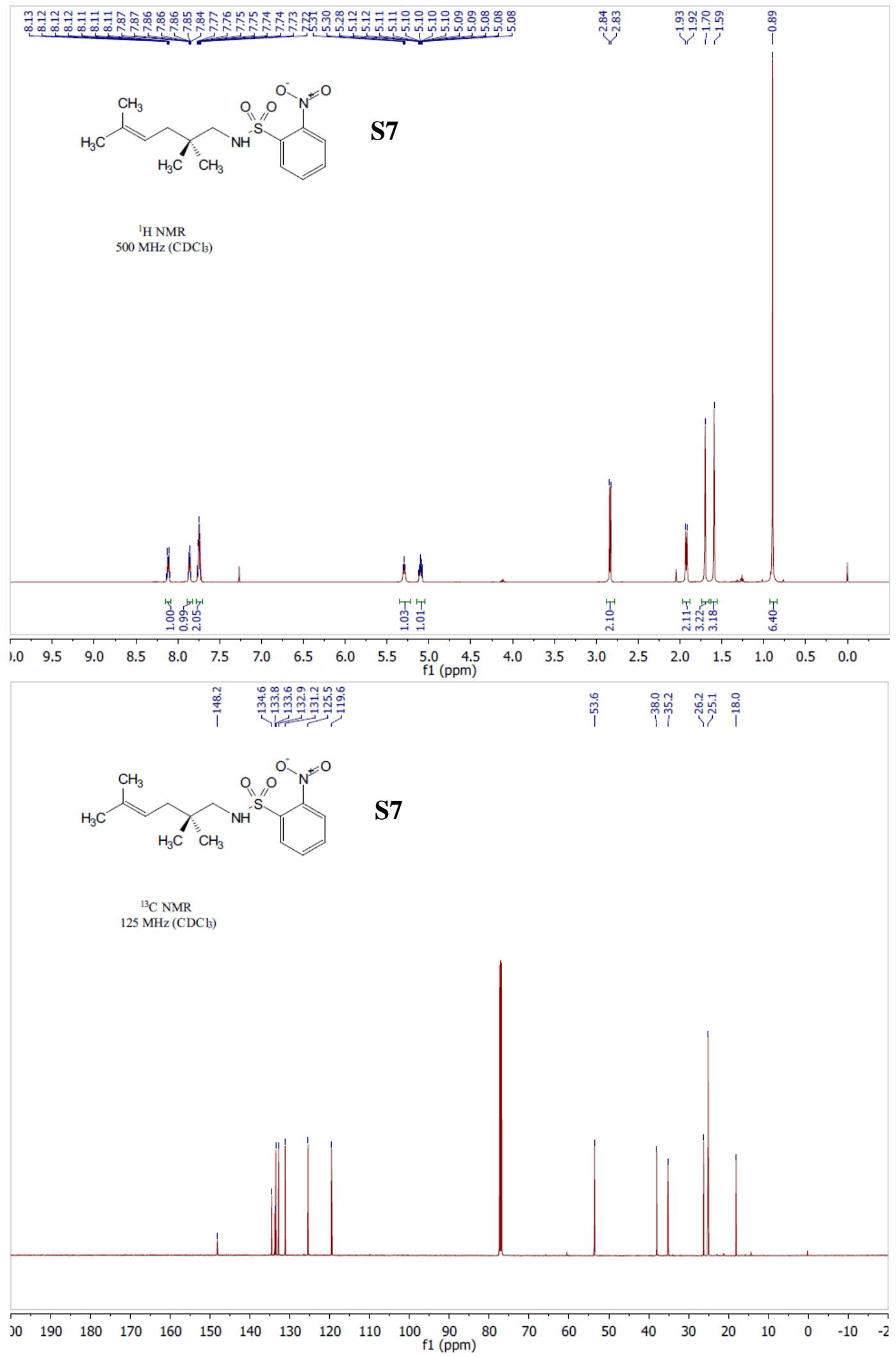



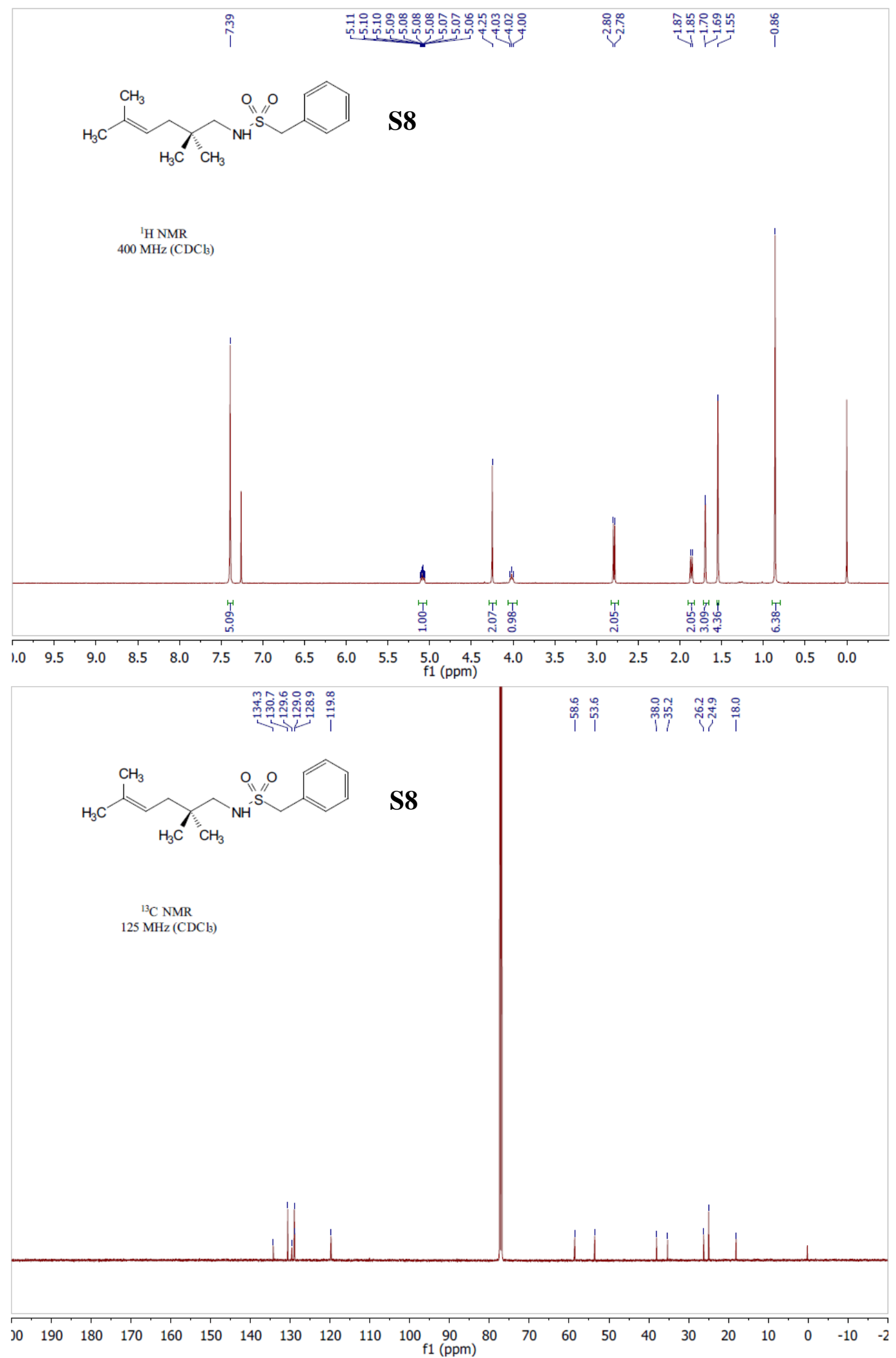


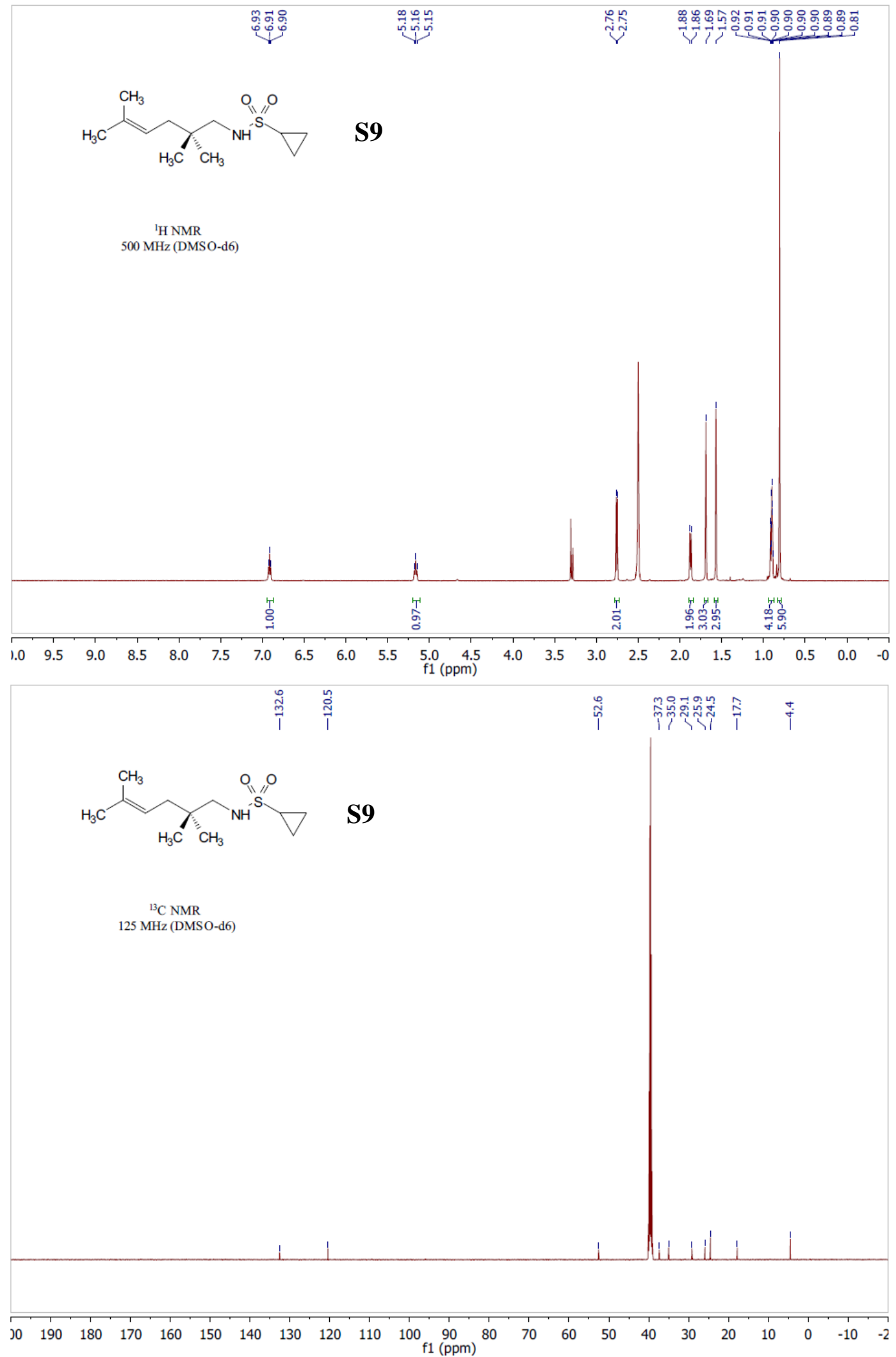



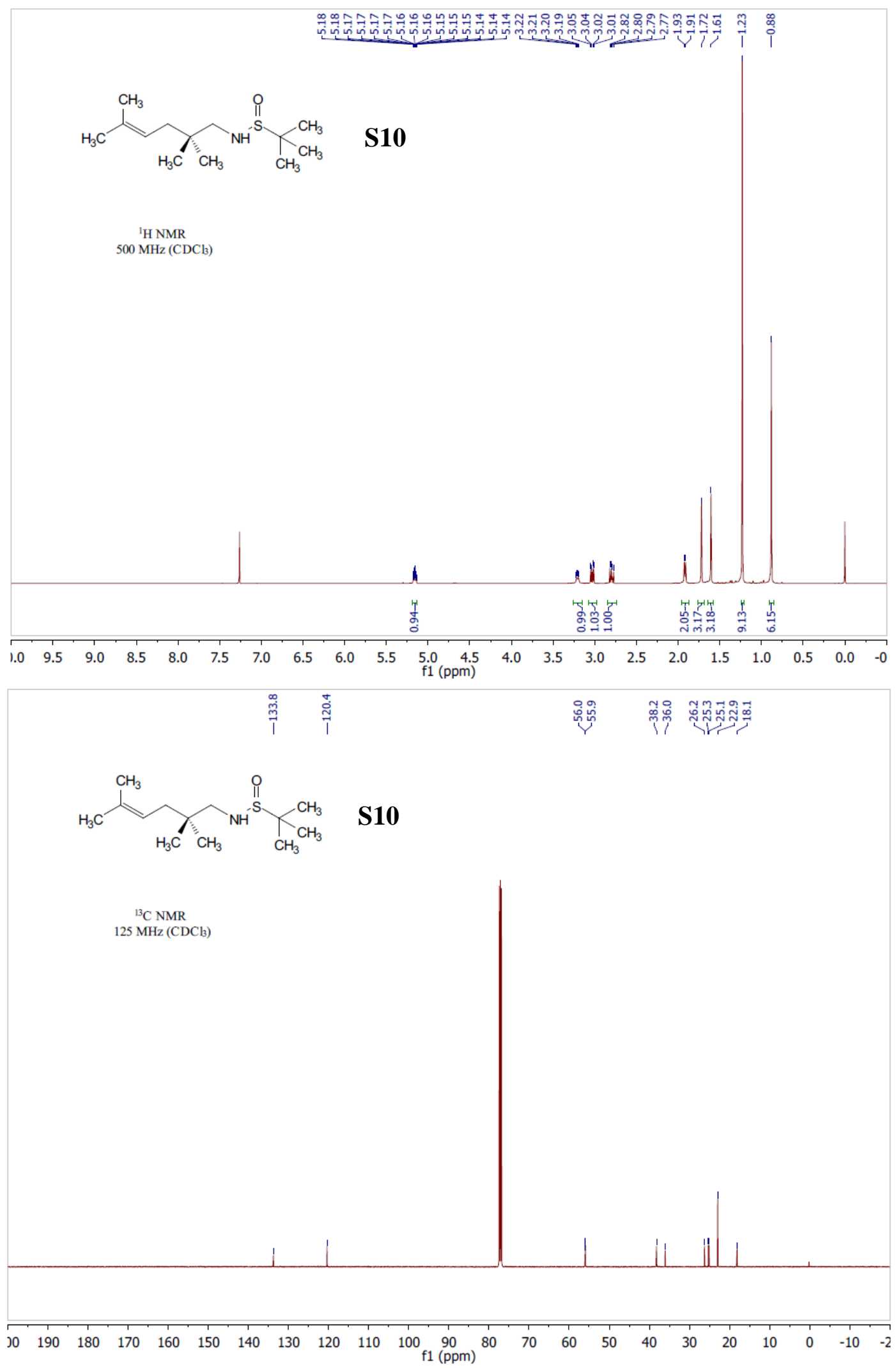


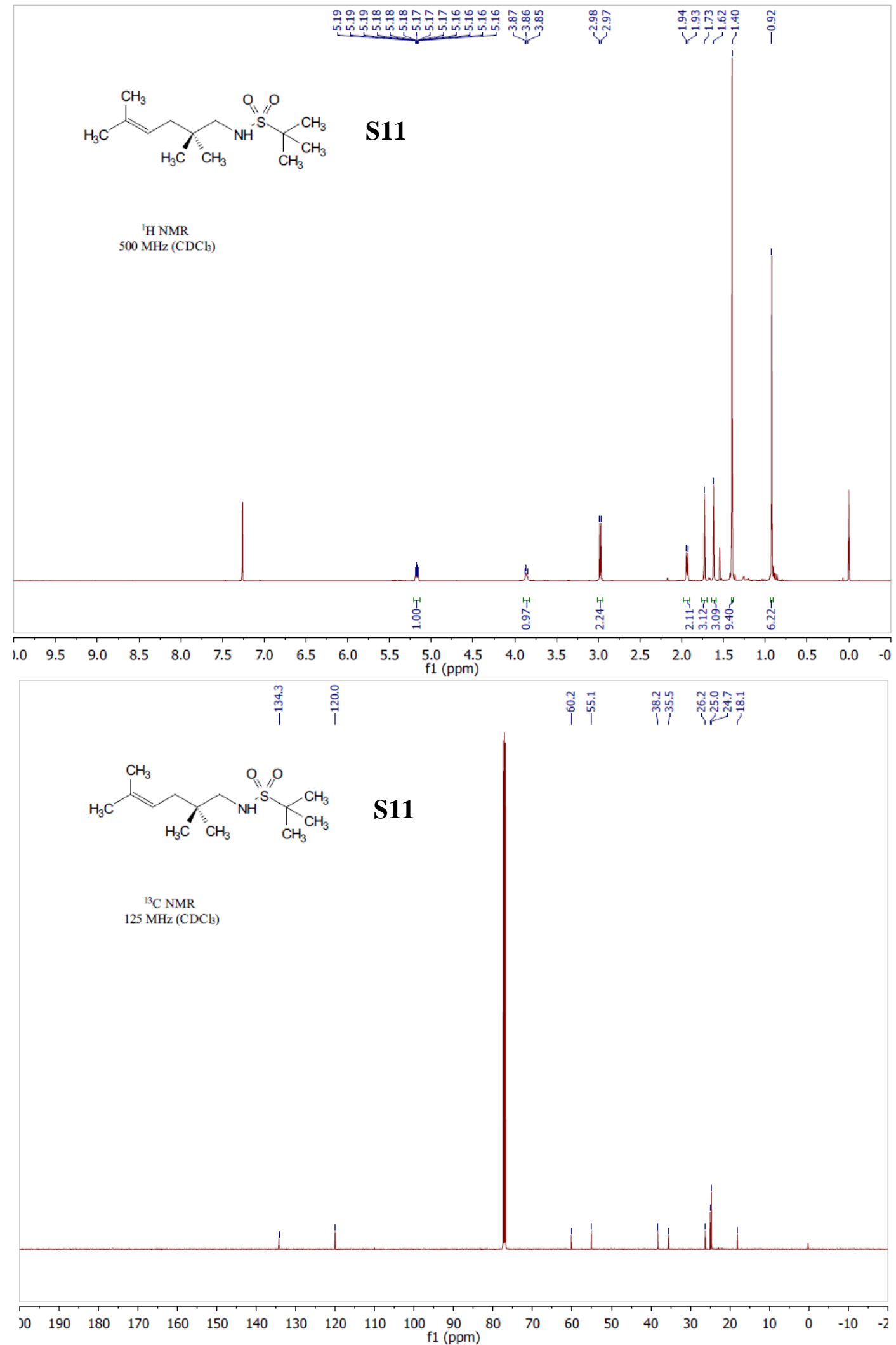




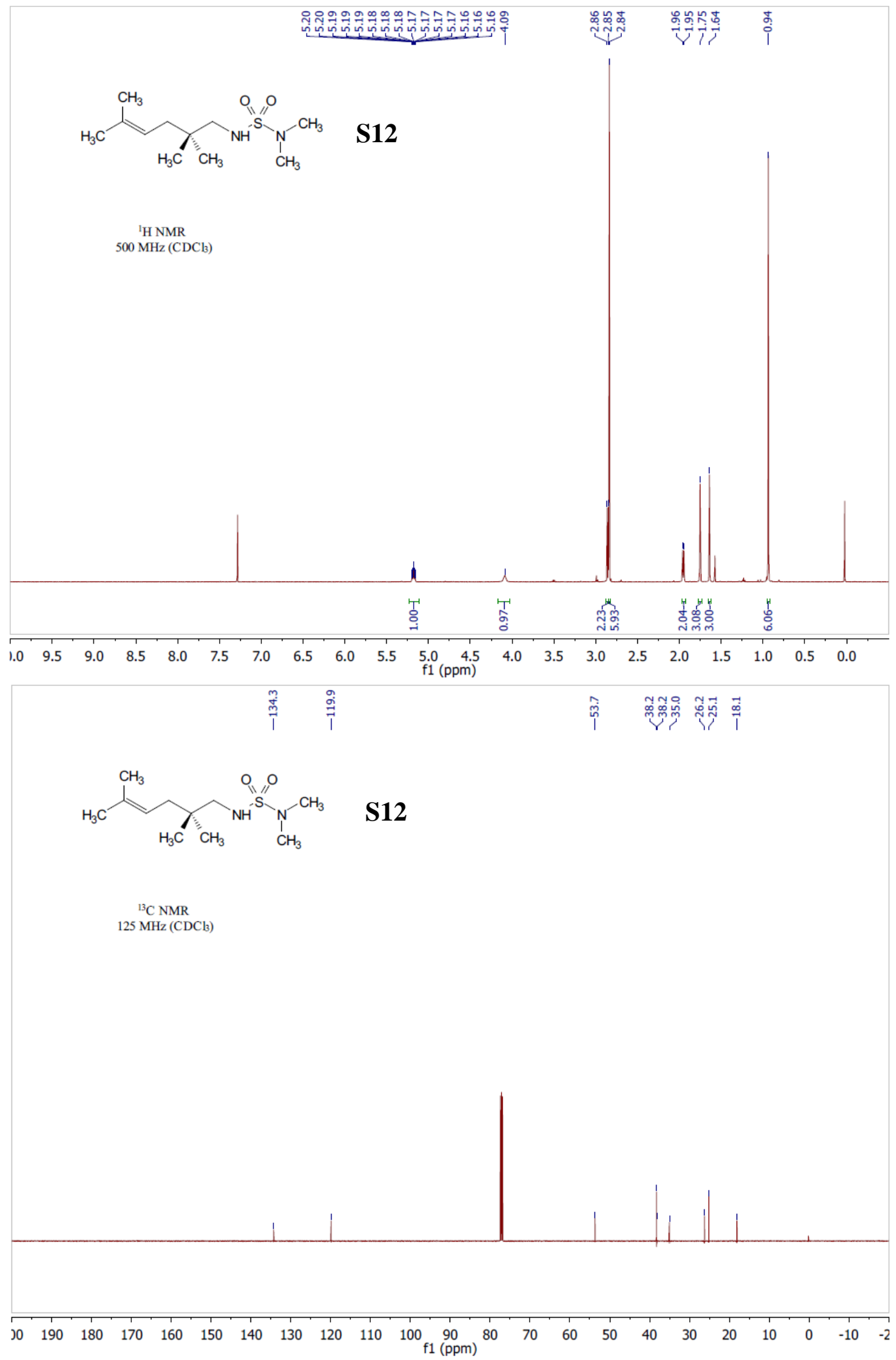




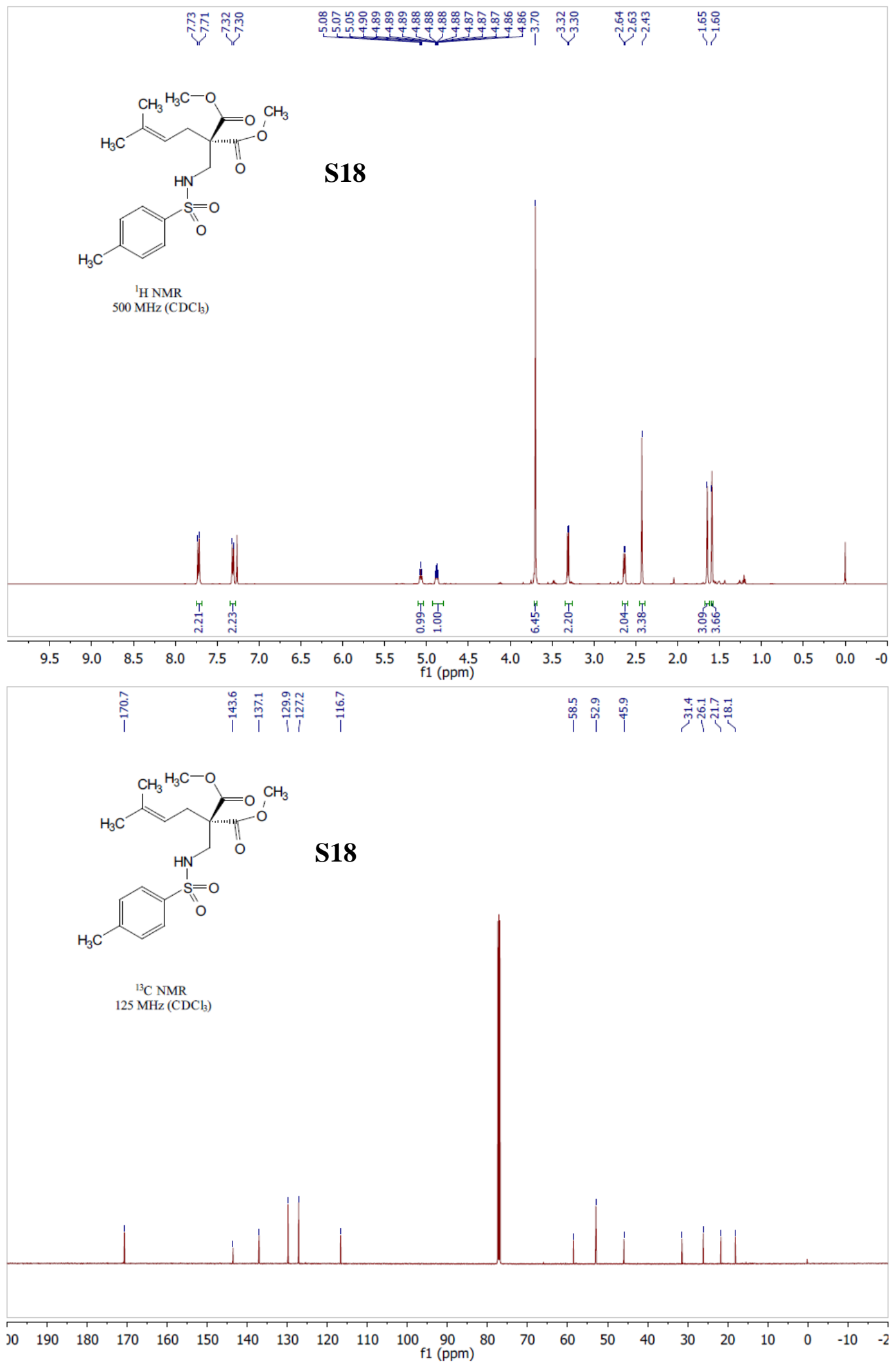




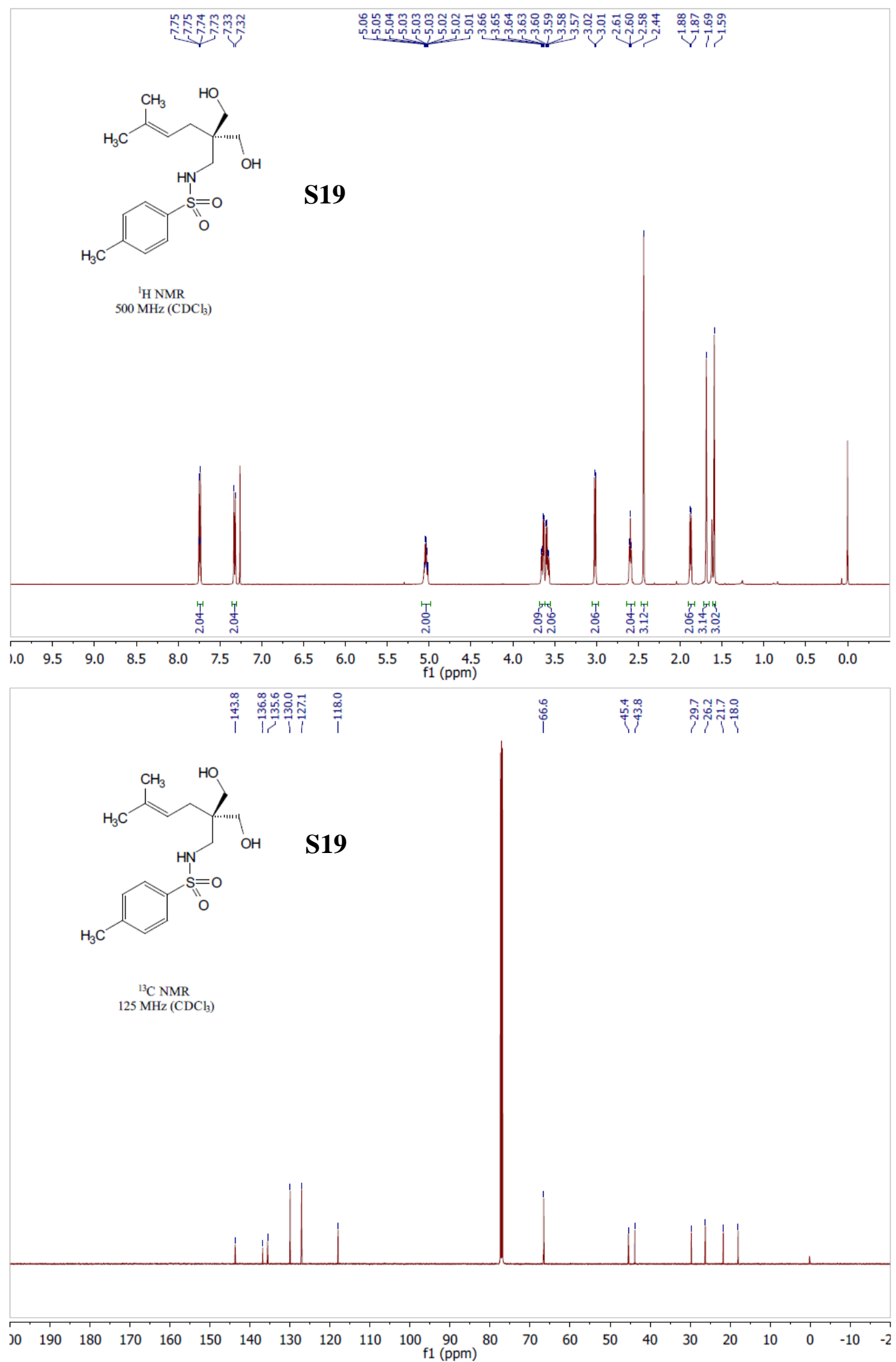



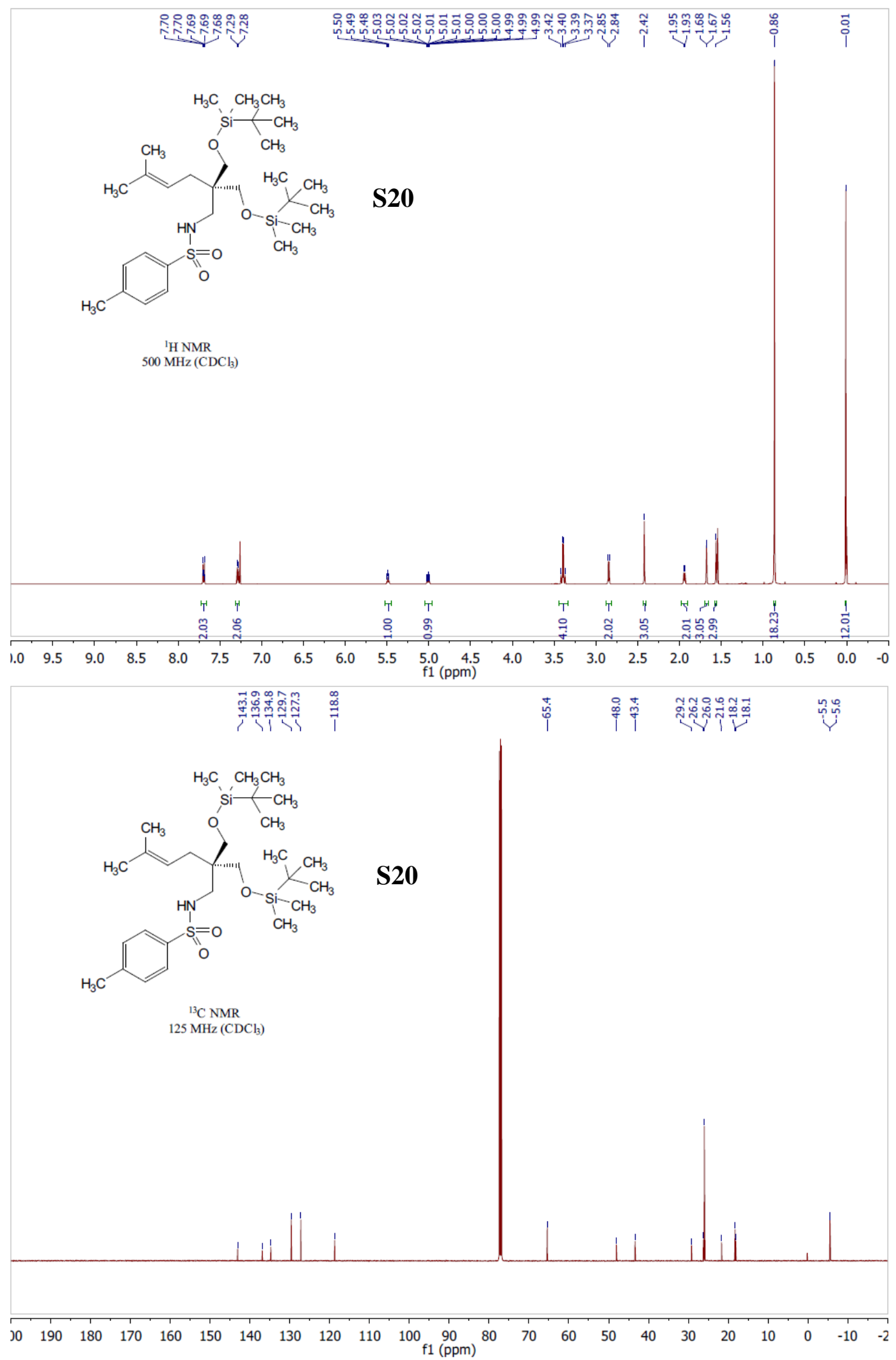

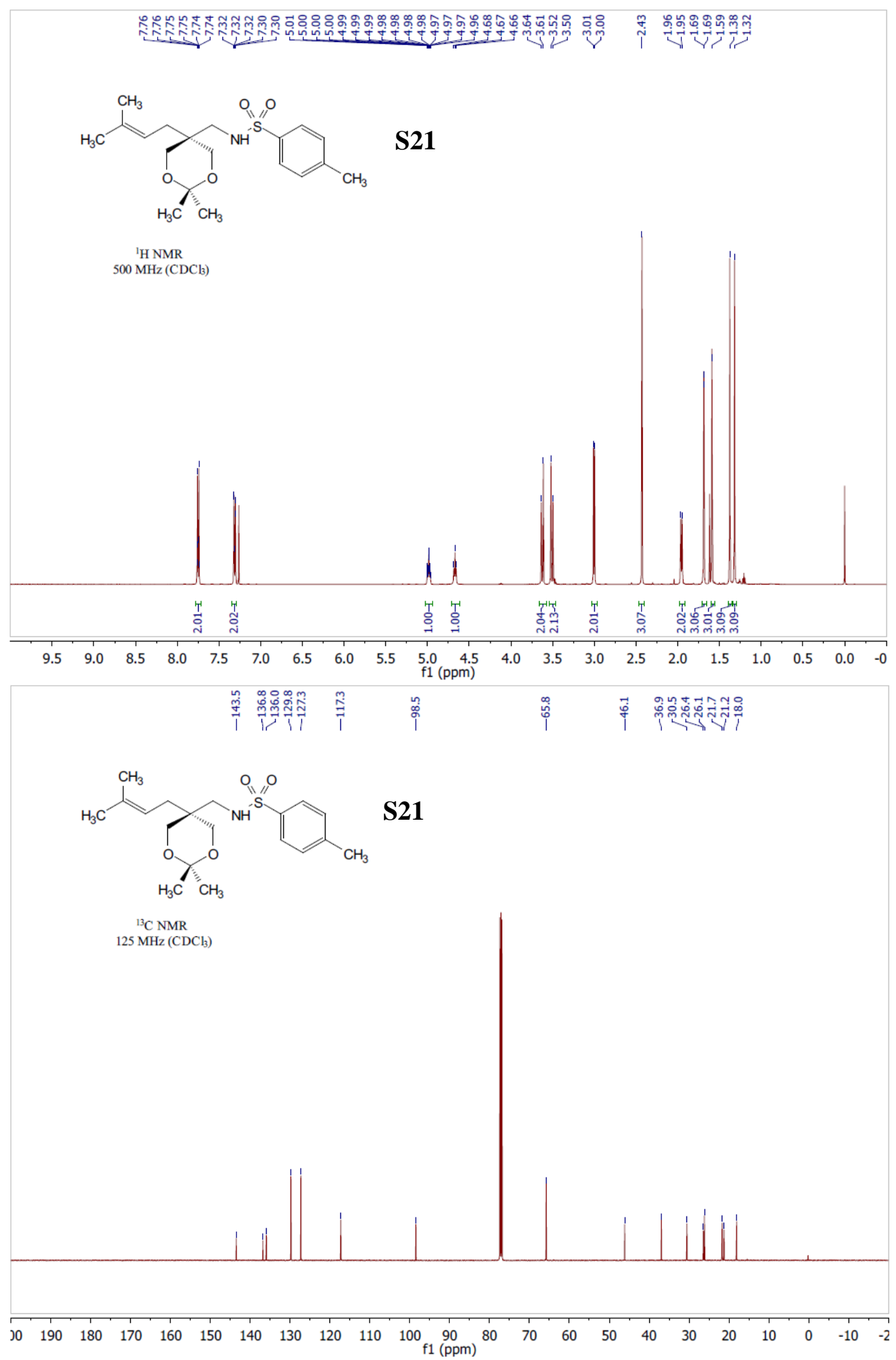

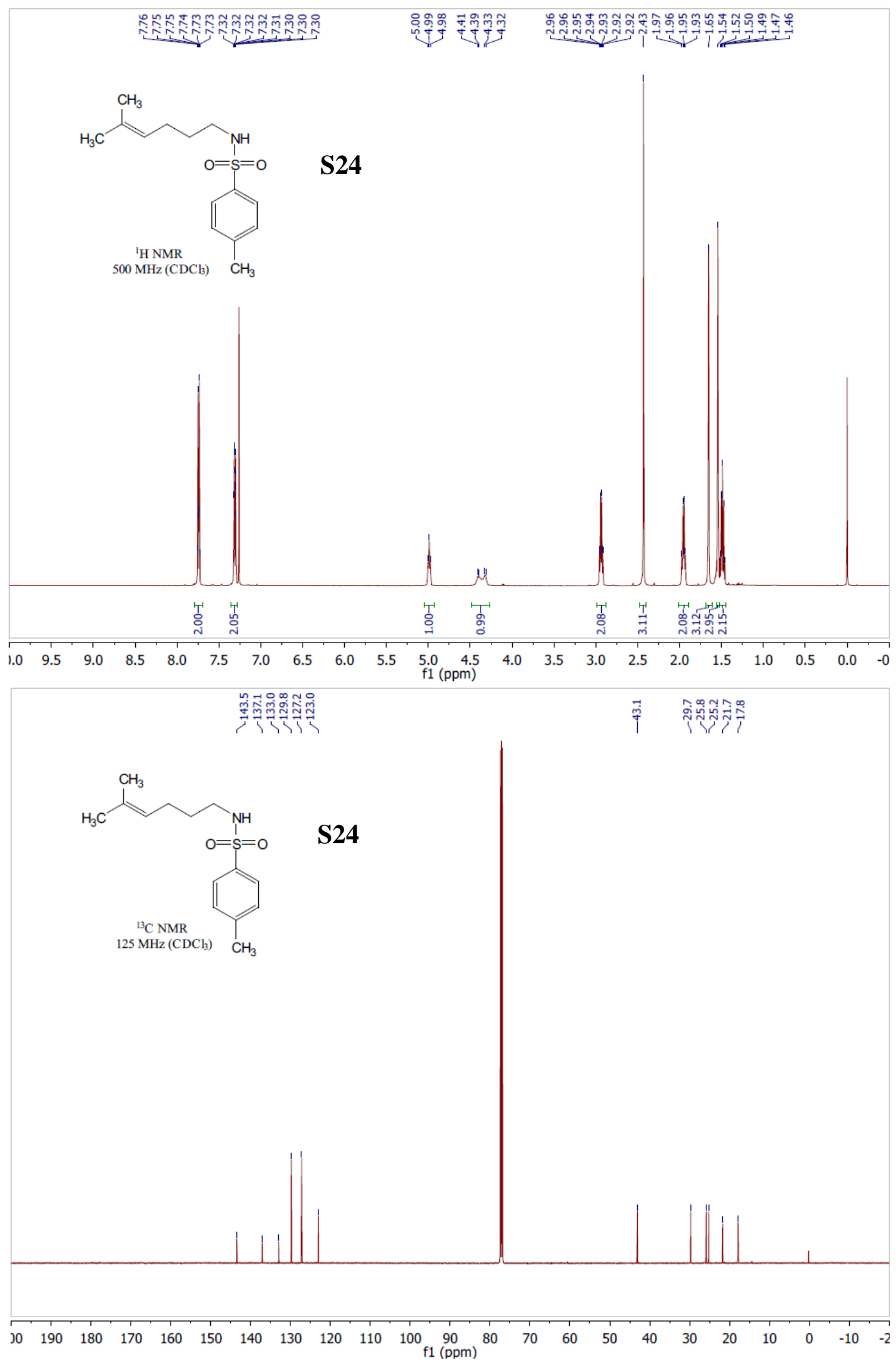

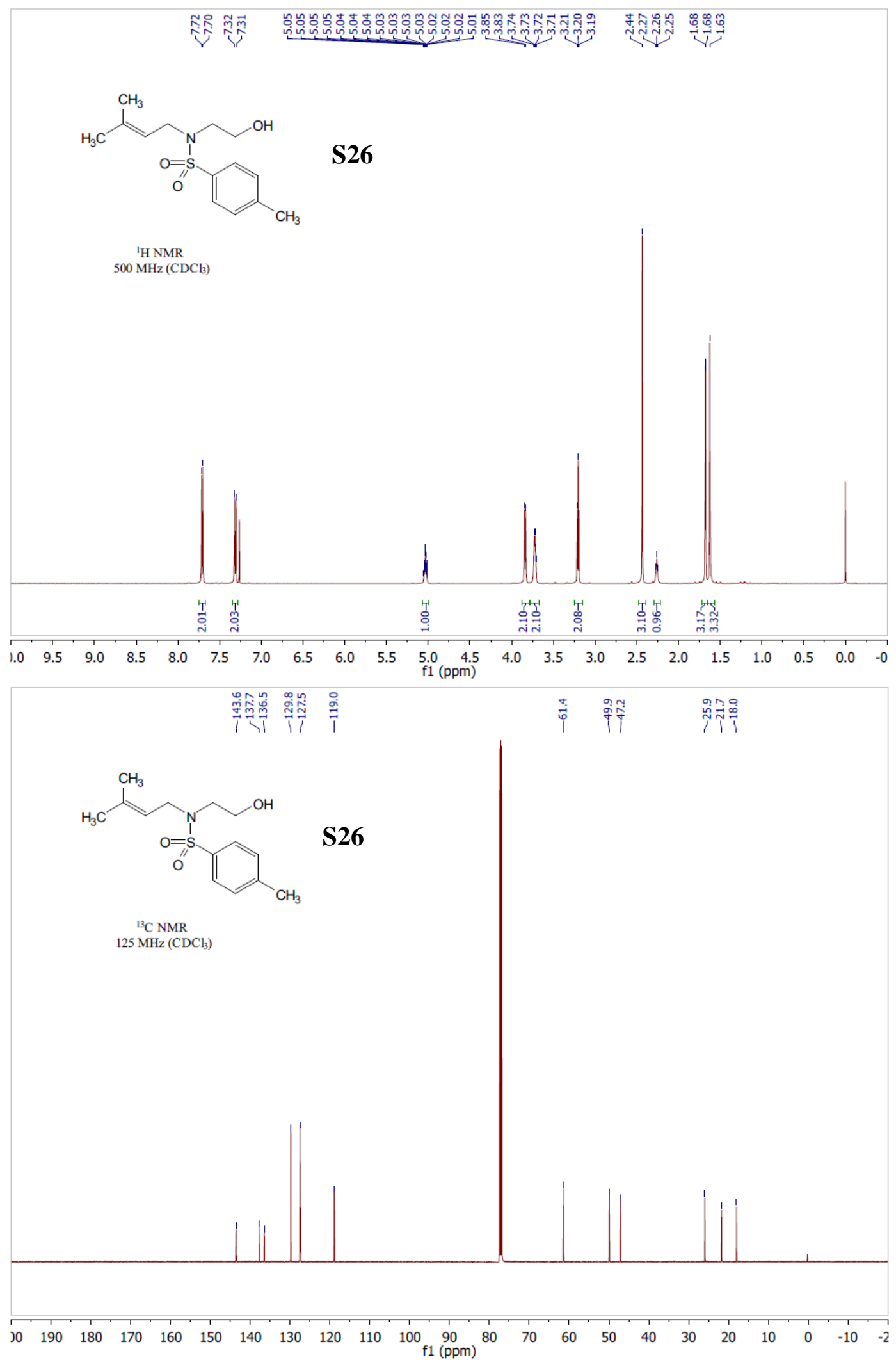

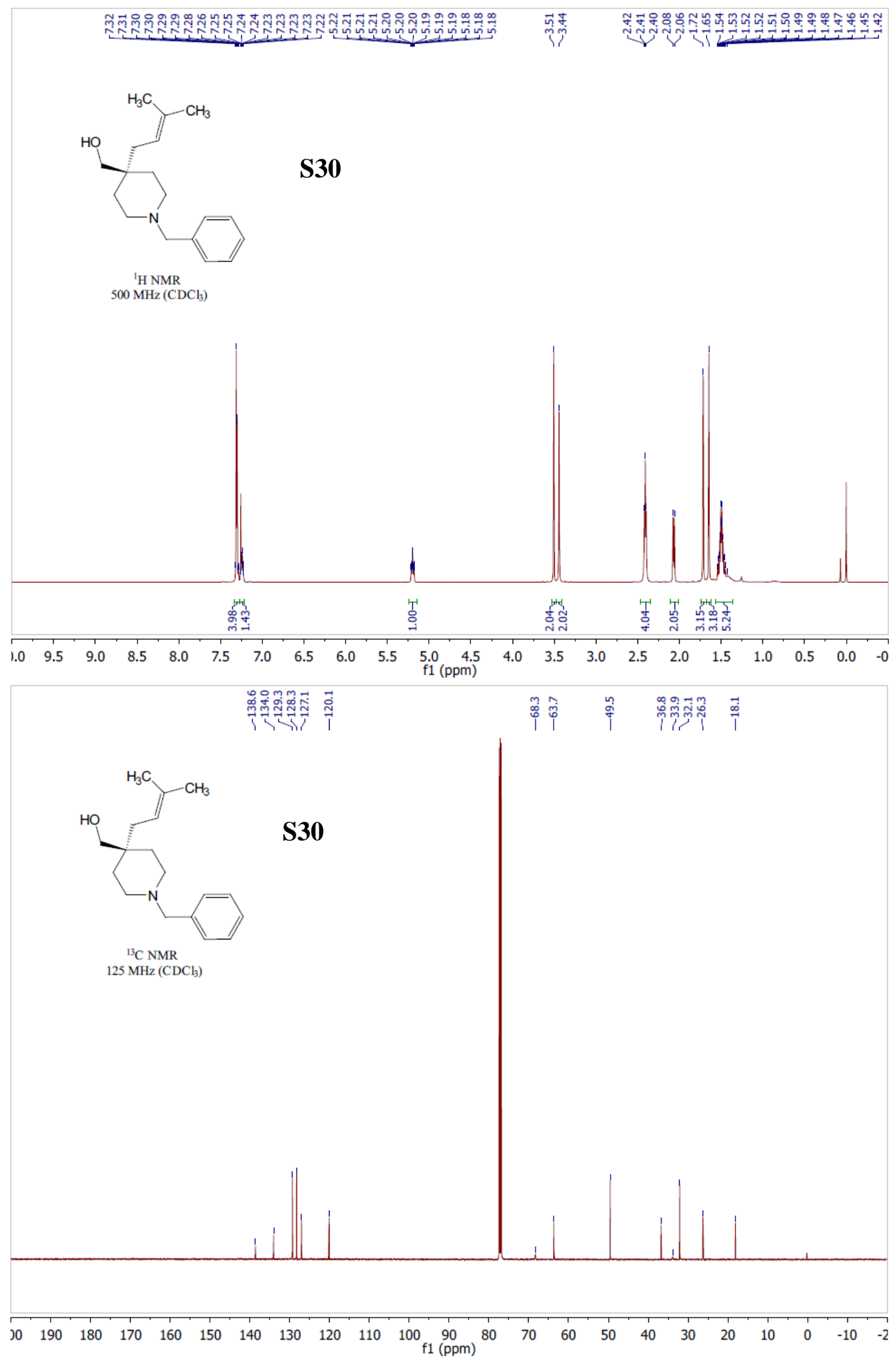


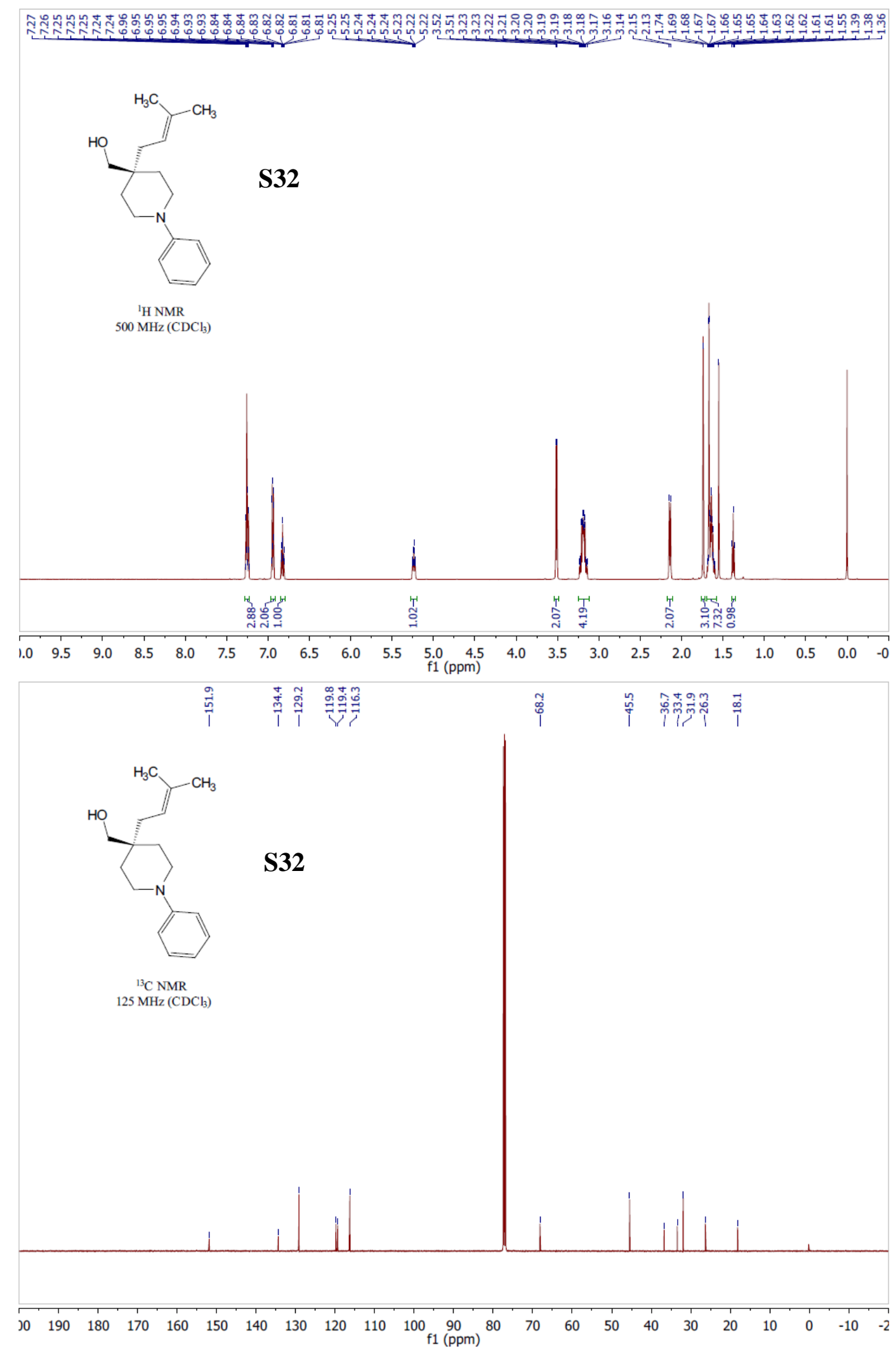



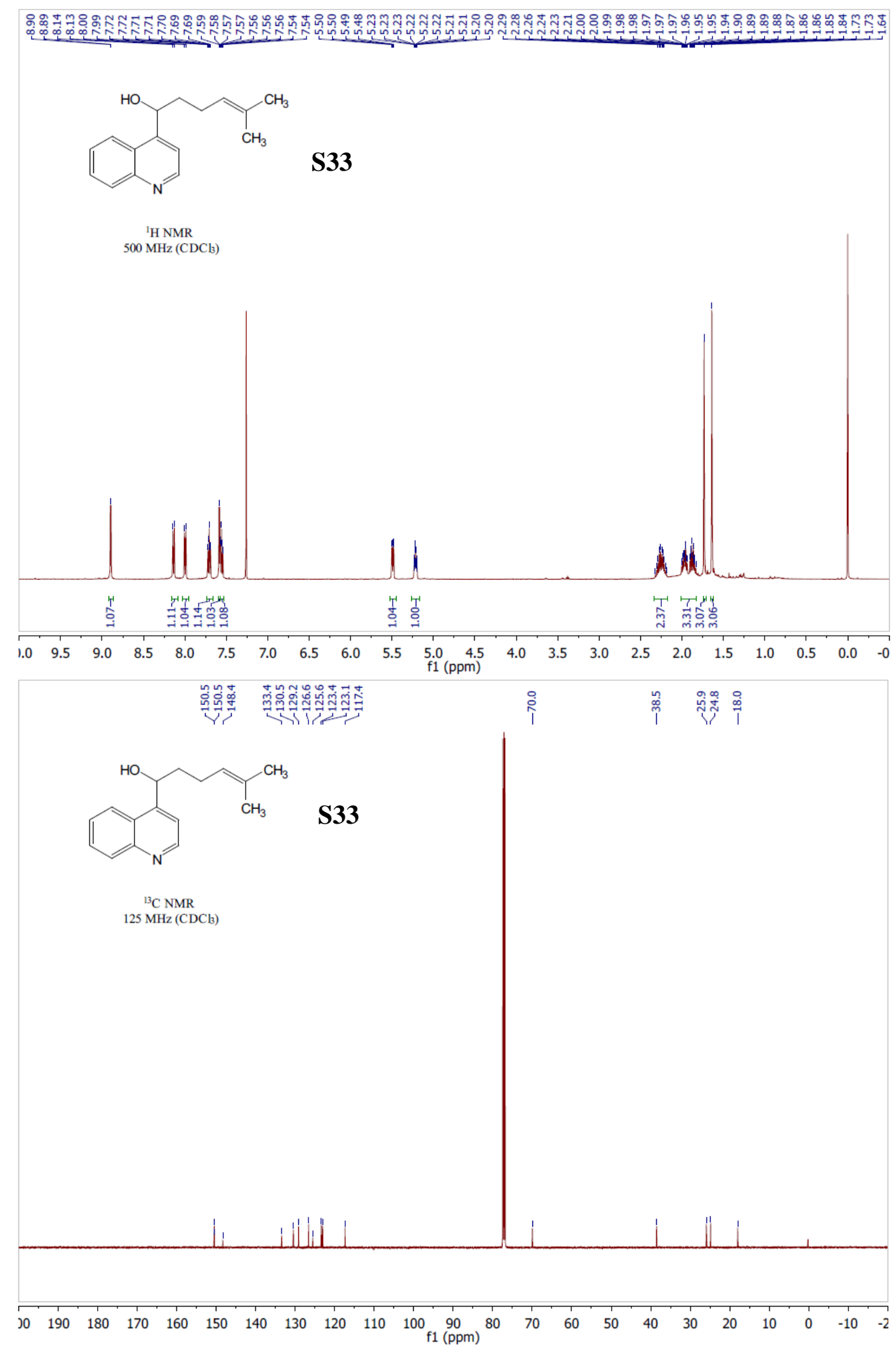


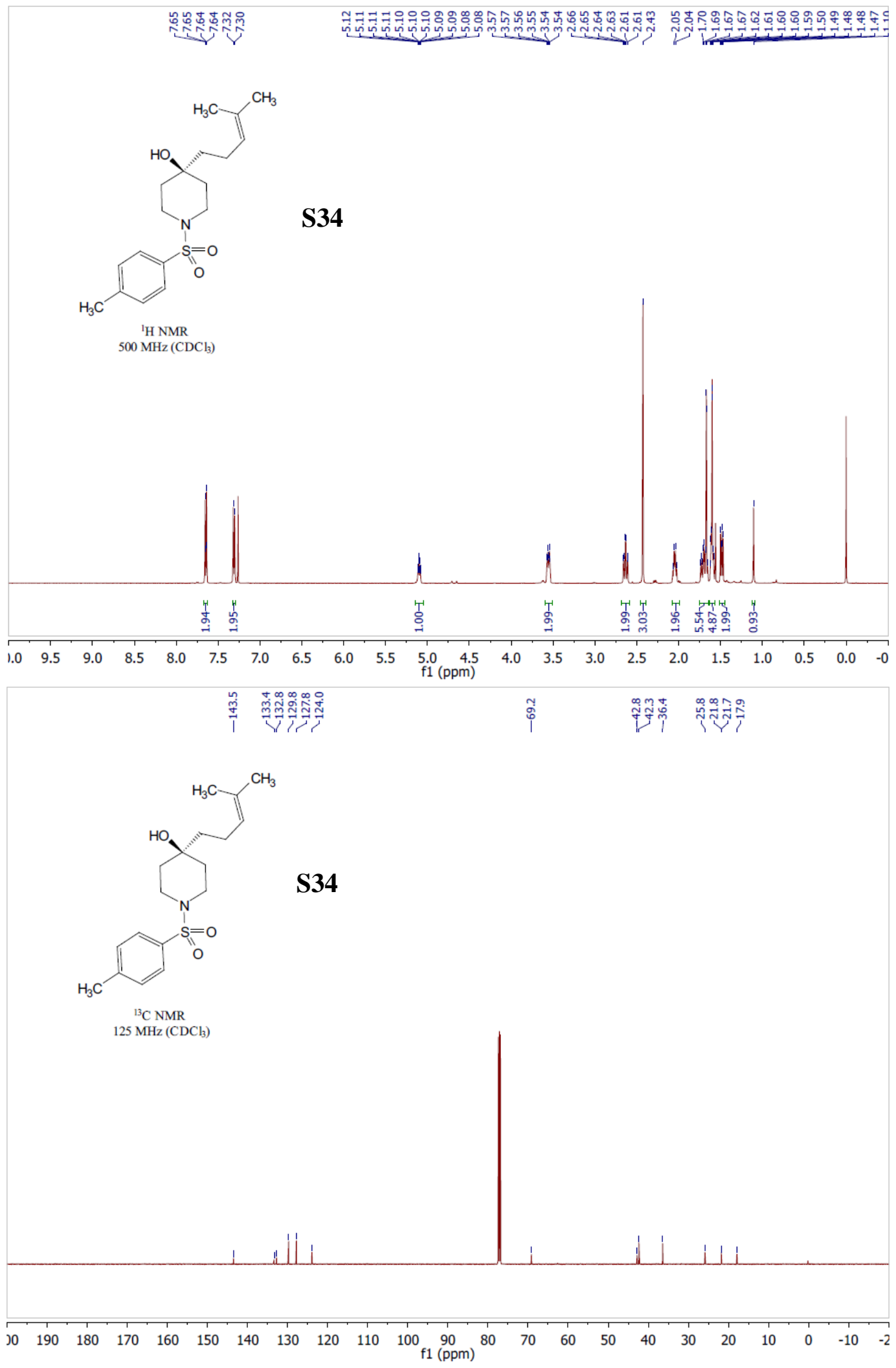



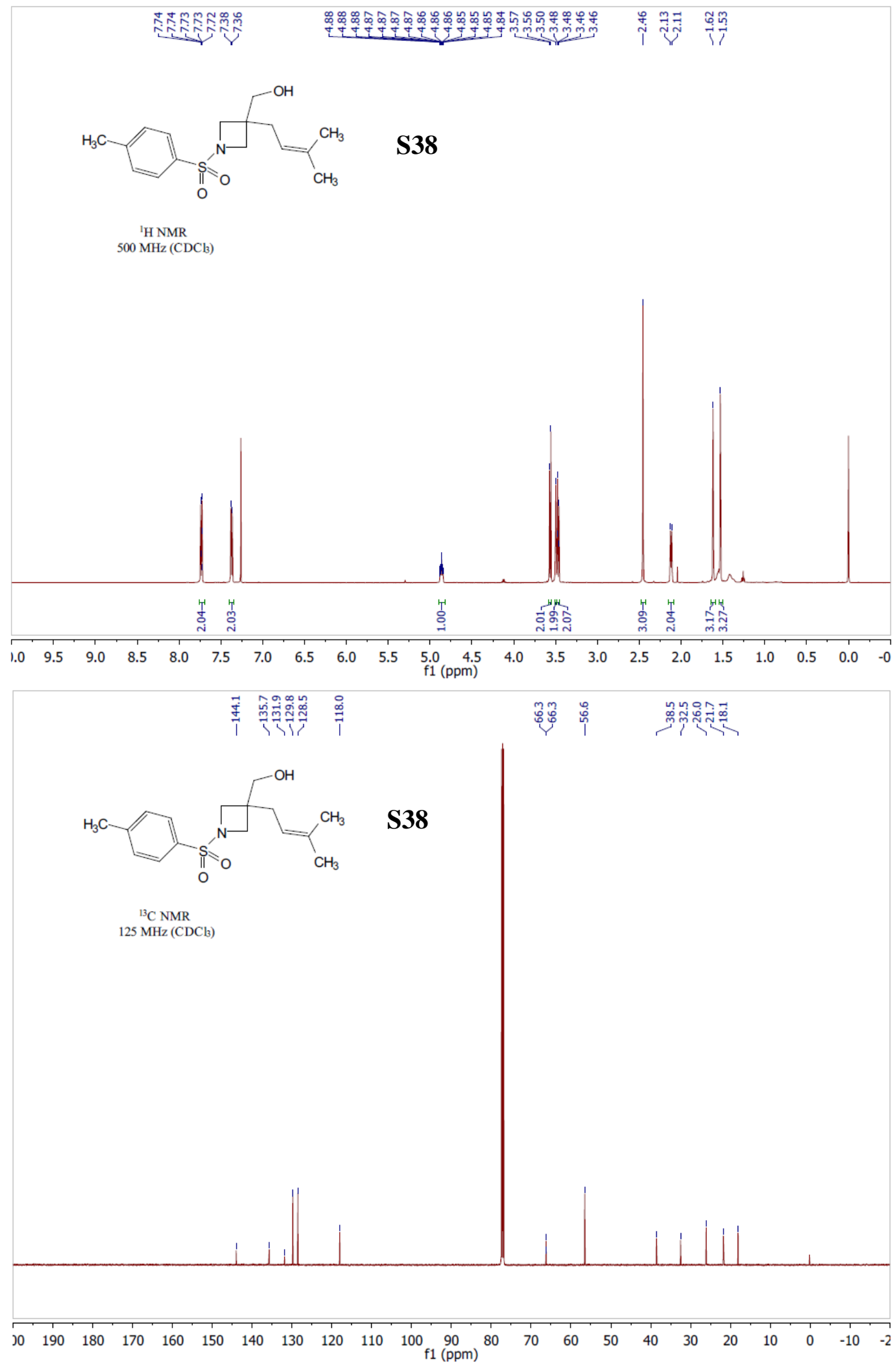


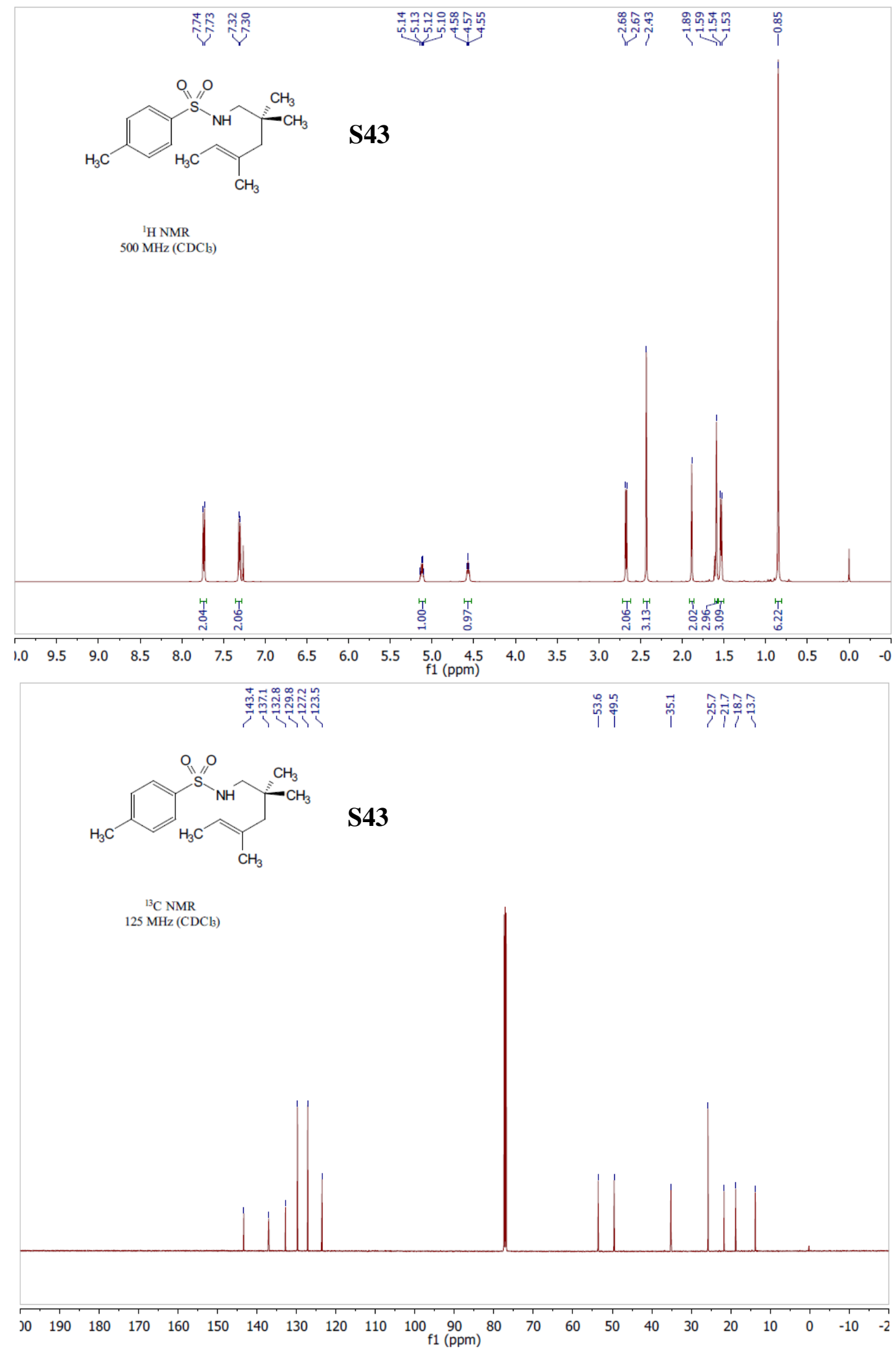



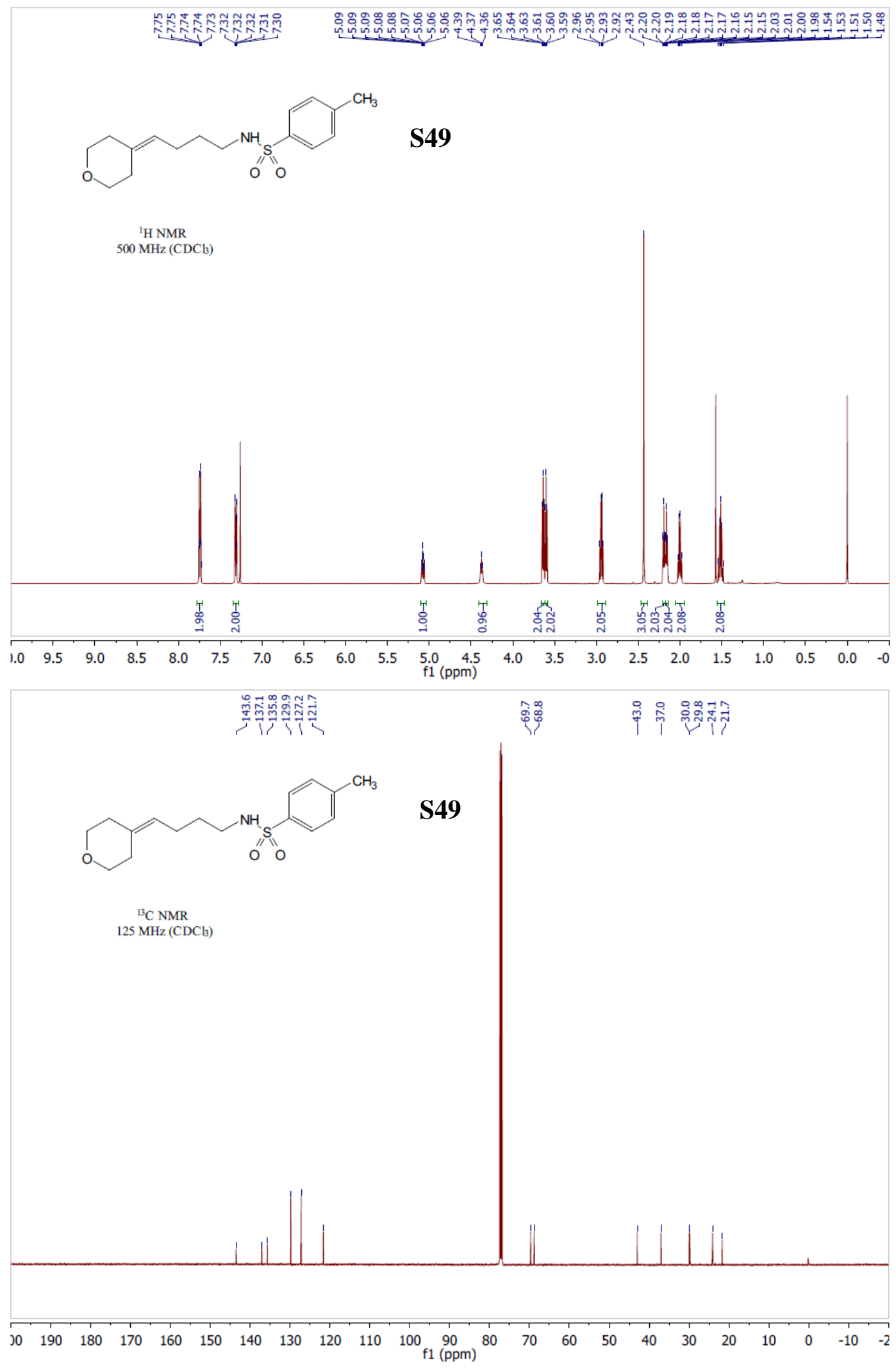


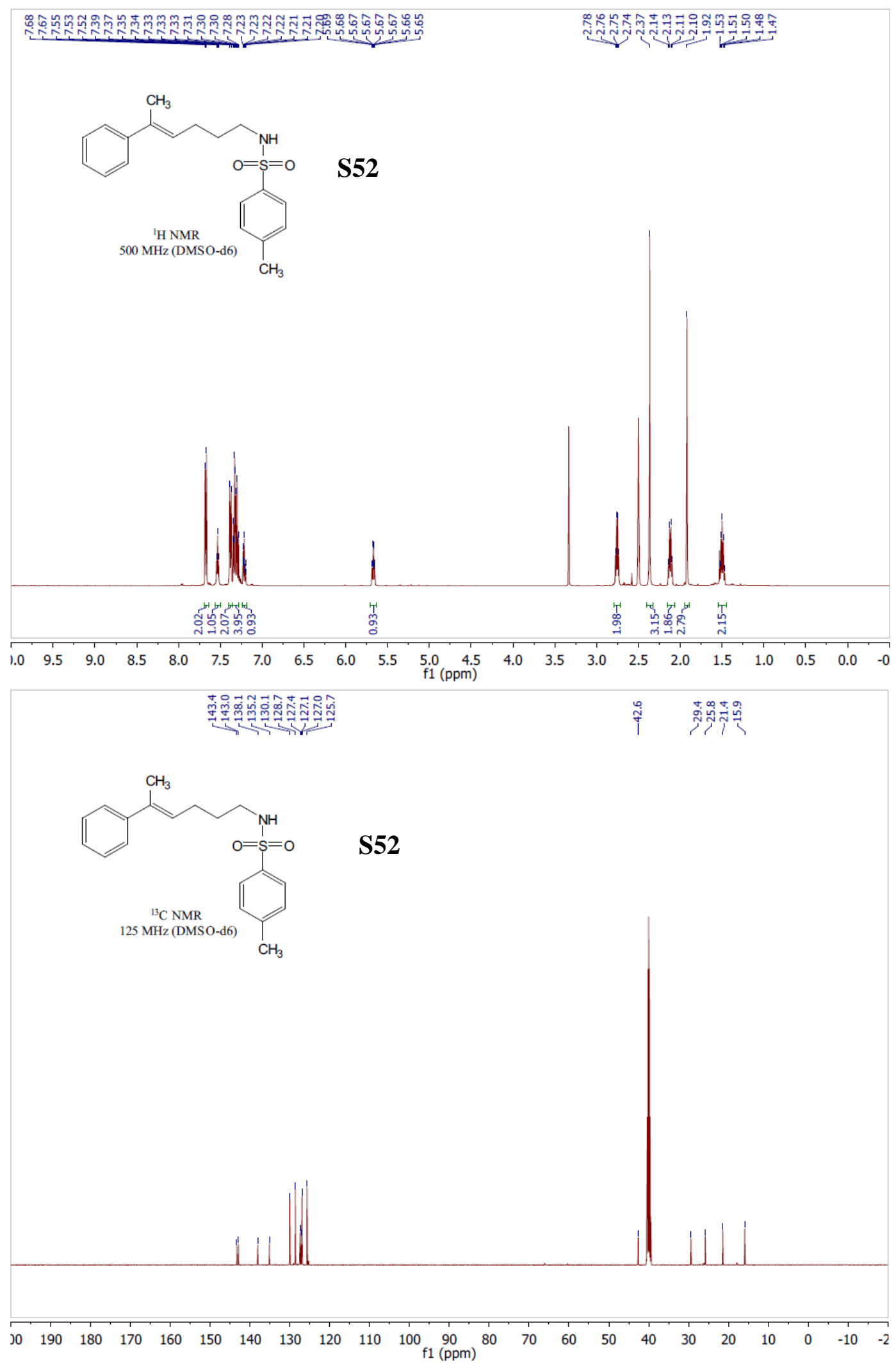




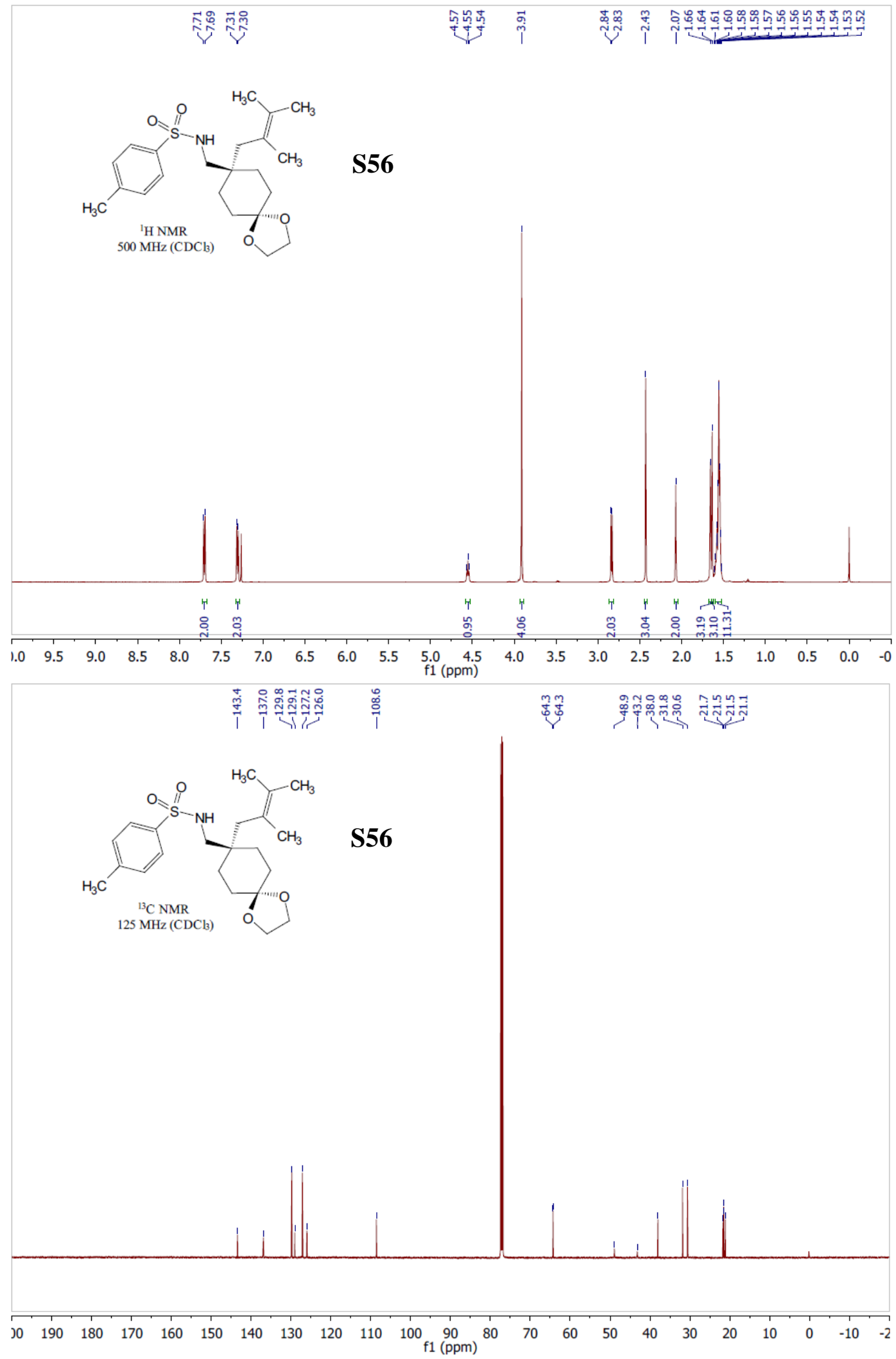



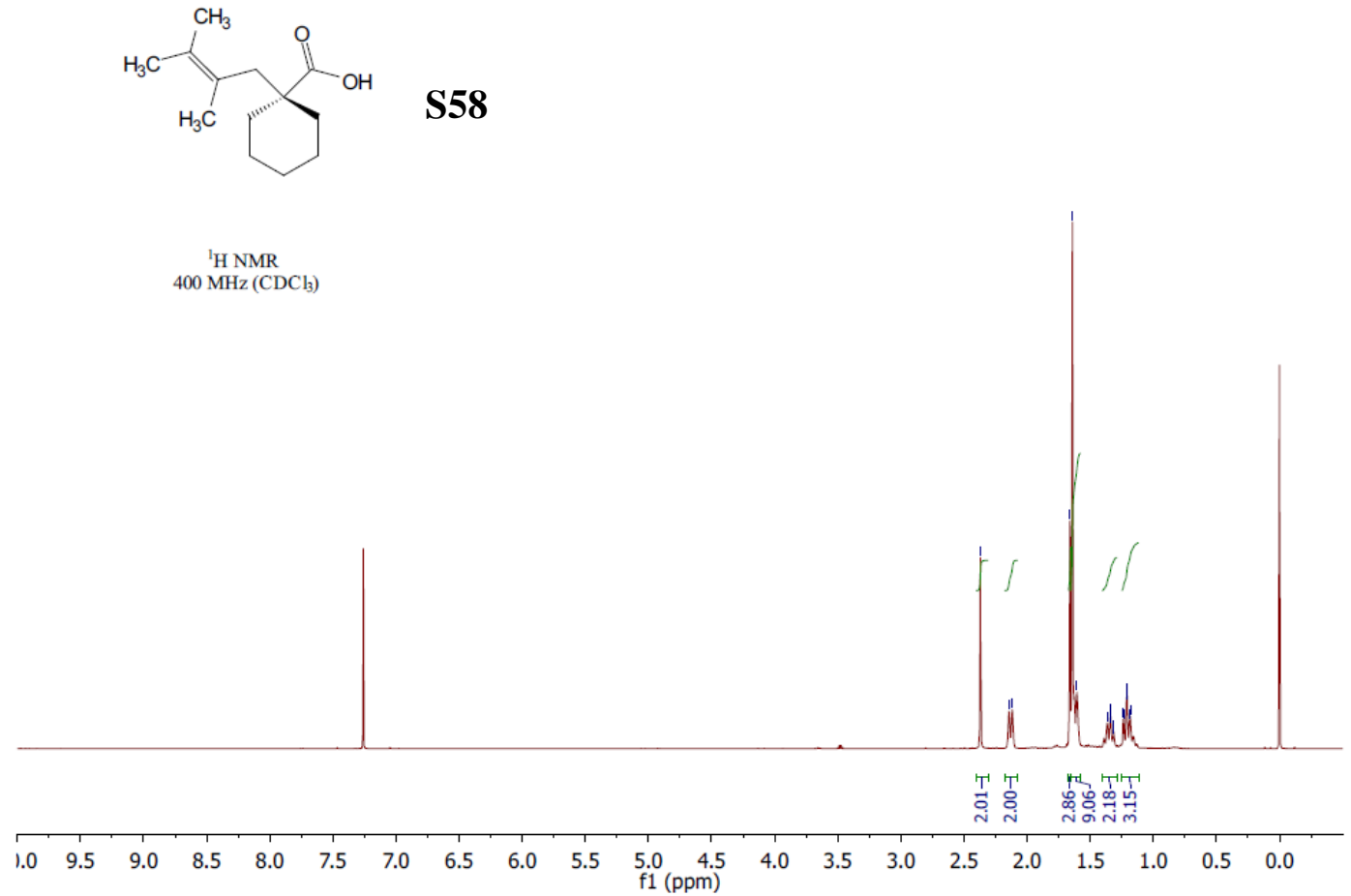

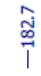
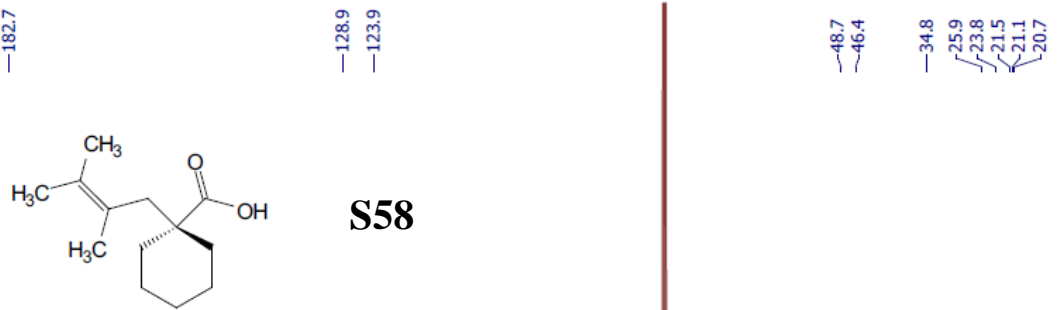

S58

${ }^{13} \mathrm{C}$ NMR

$100 \mathrm{MHz}\left(\mathrm{CDCl}_{3}\right)$

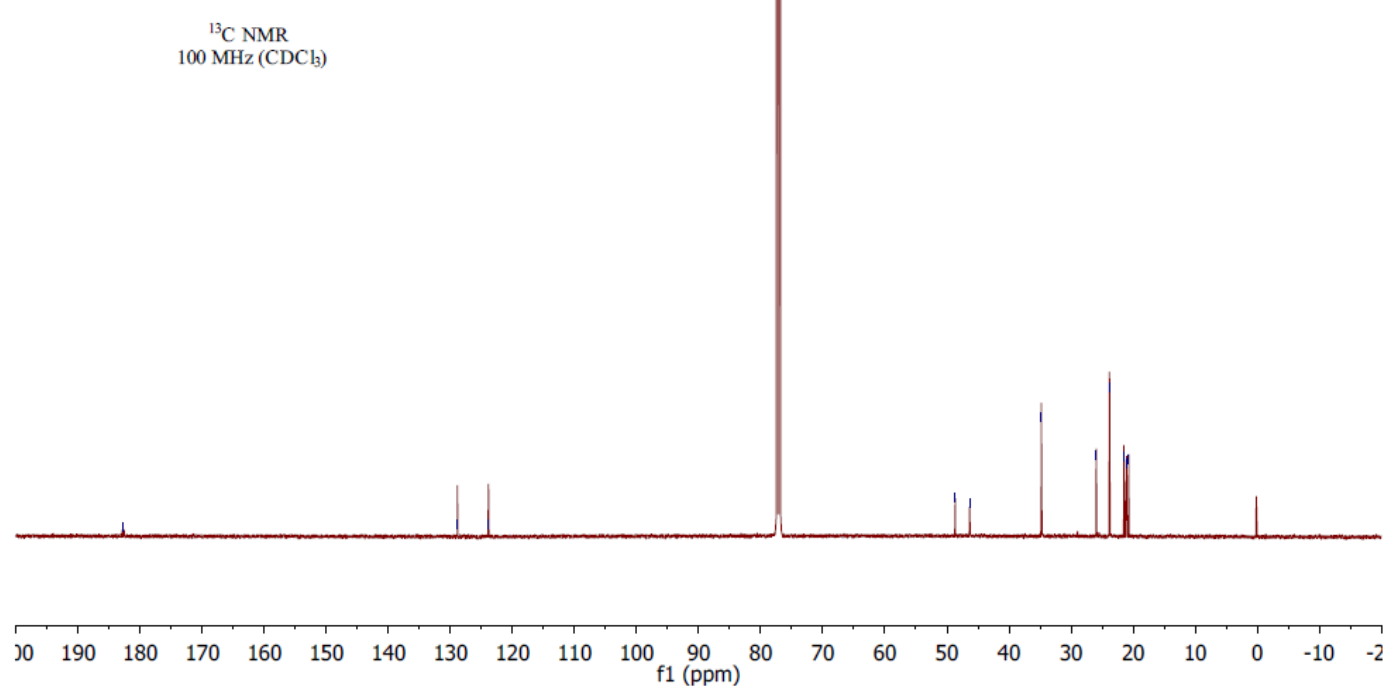




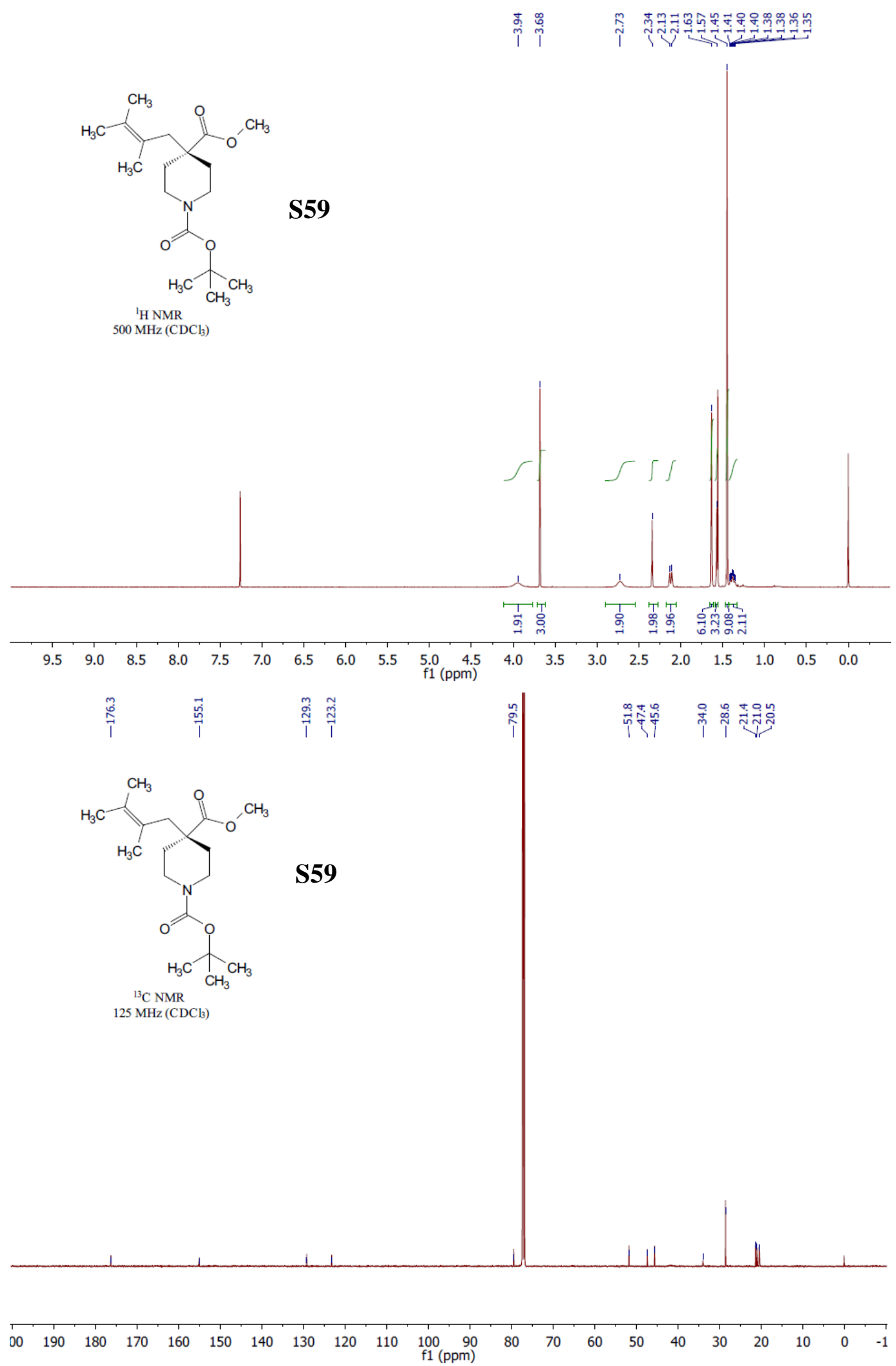




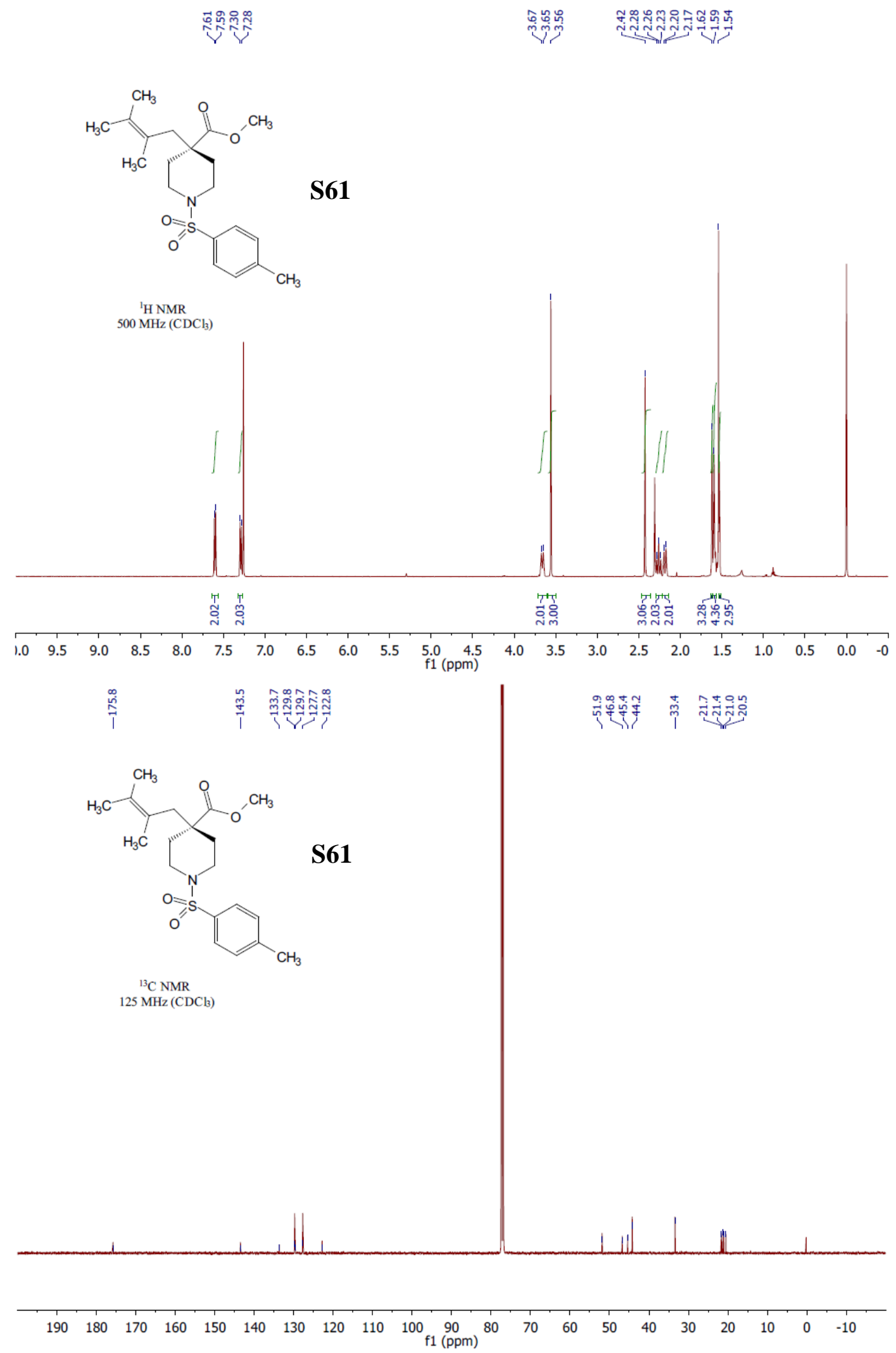




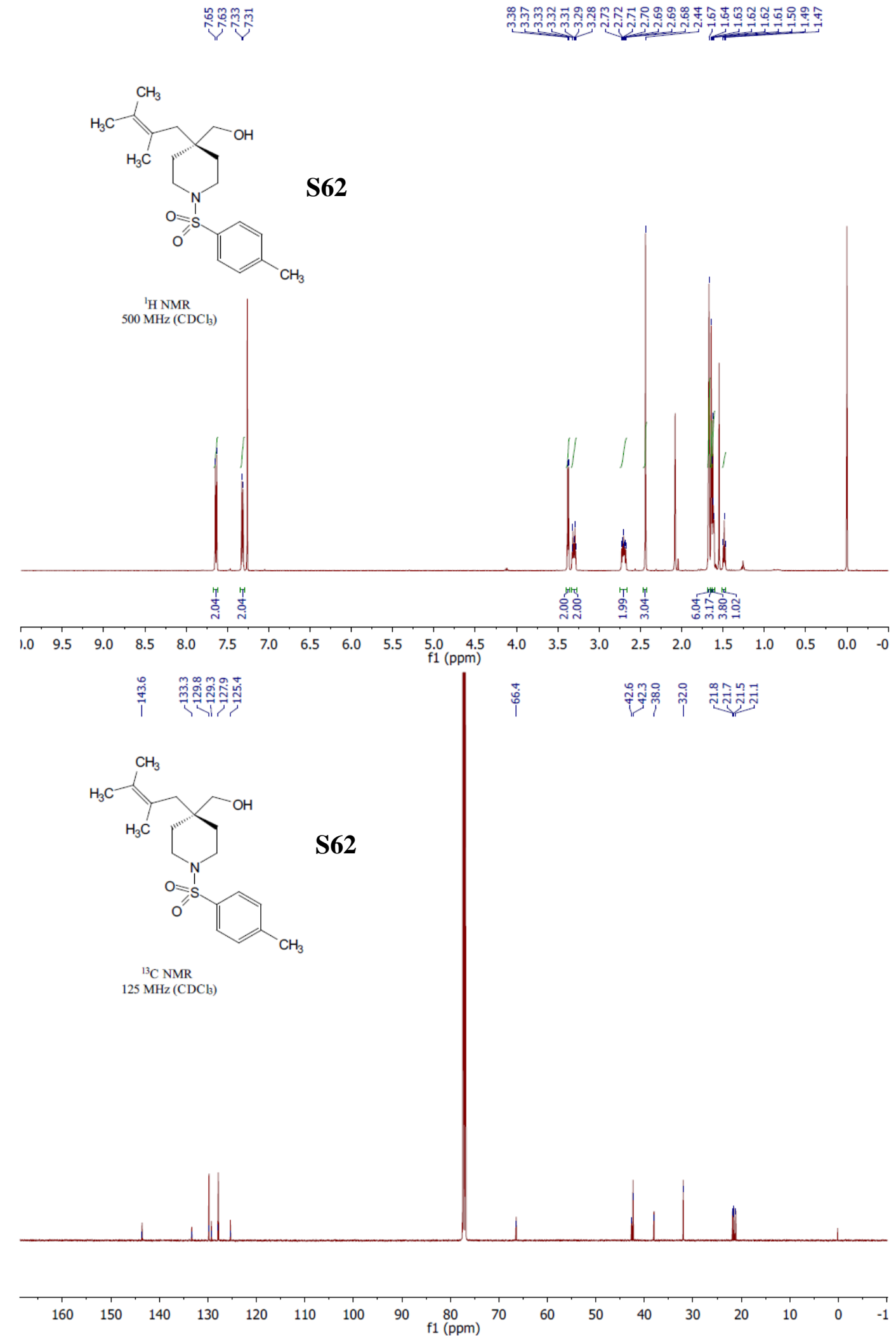




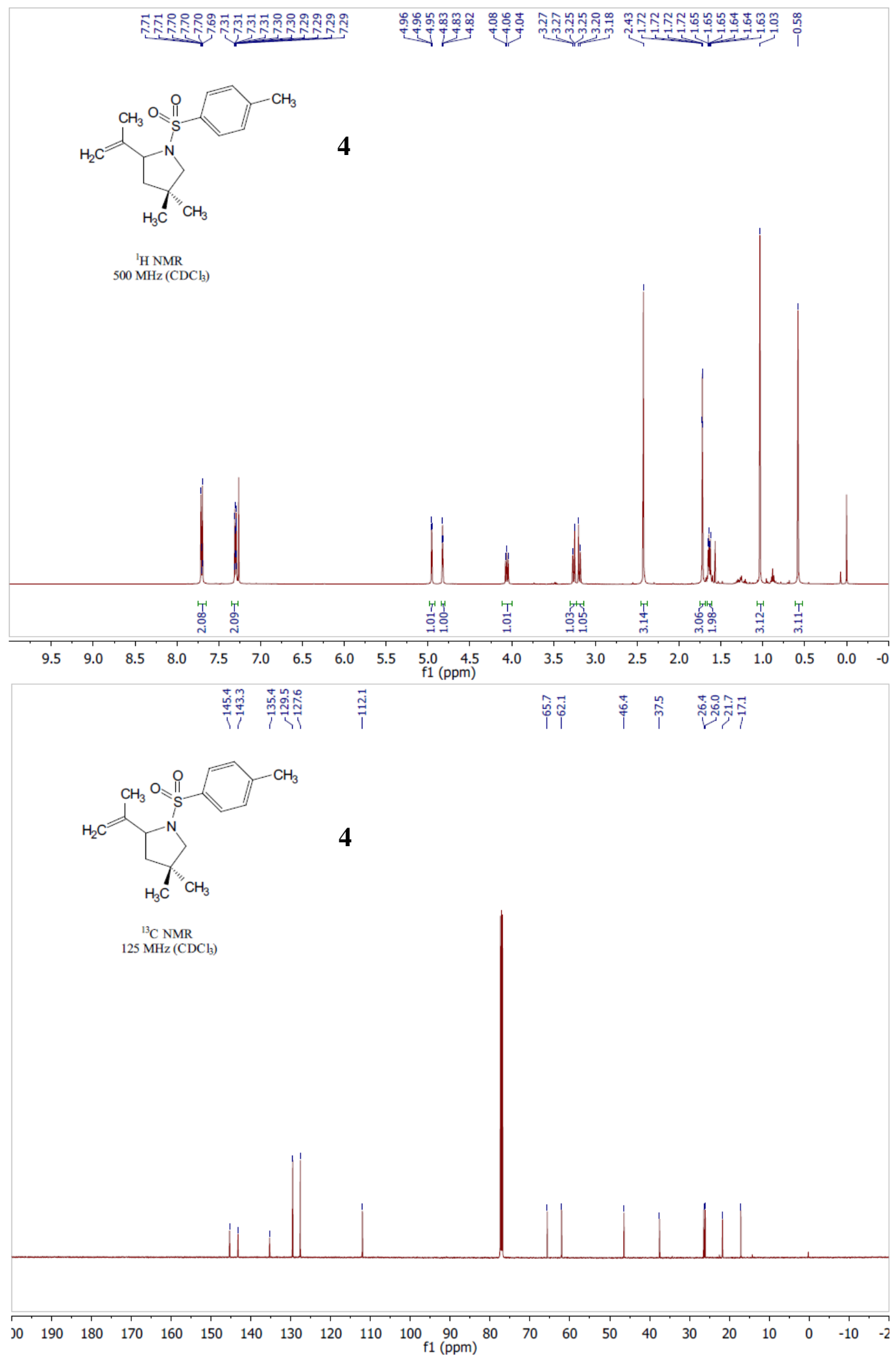




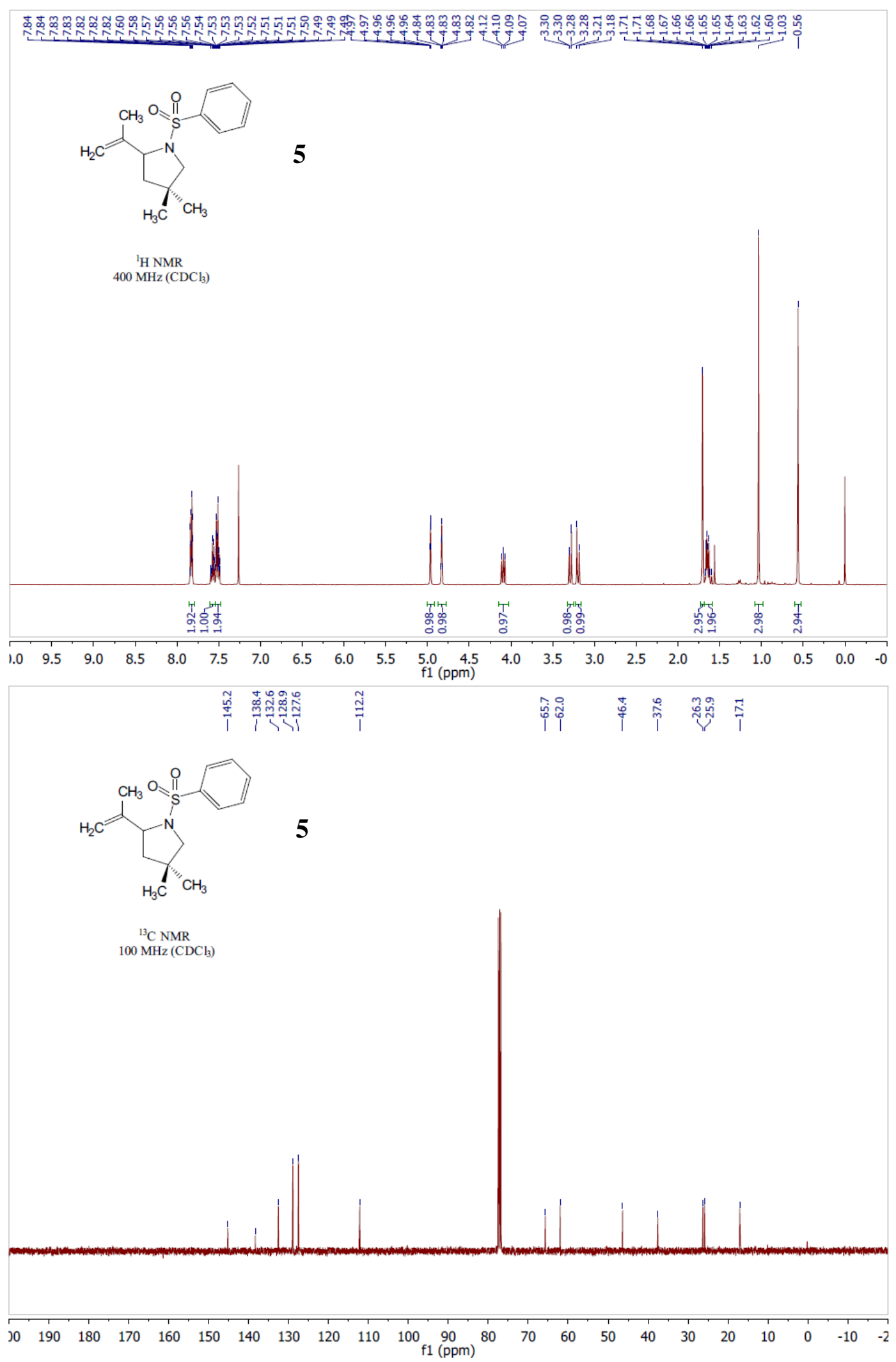




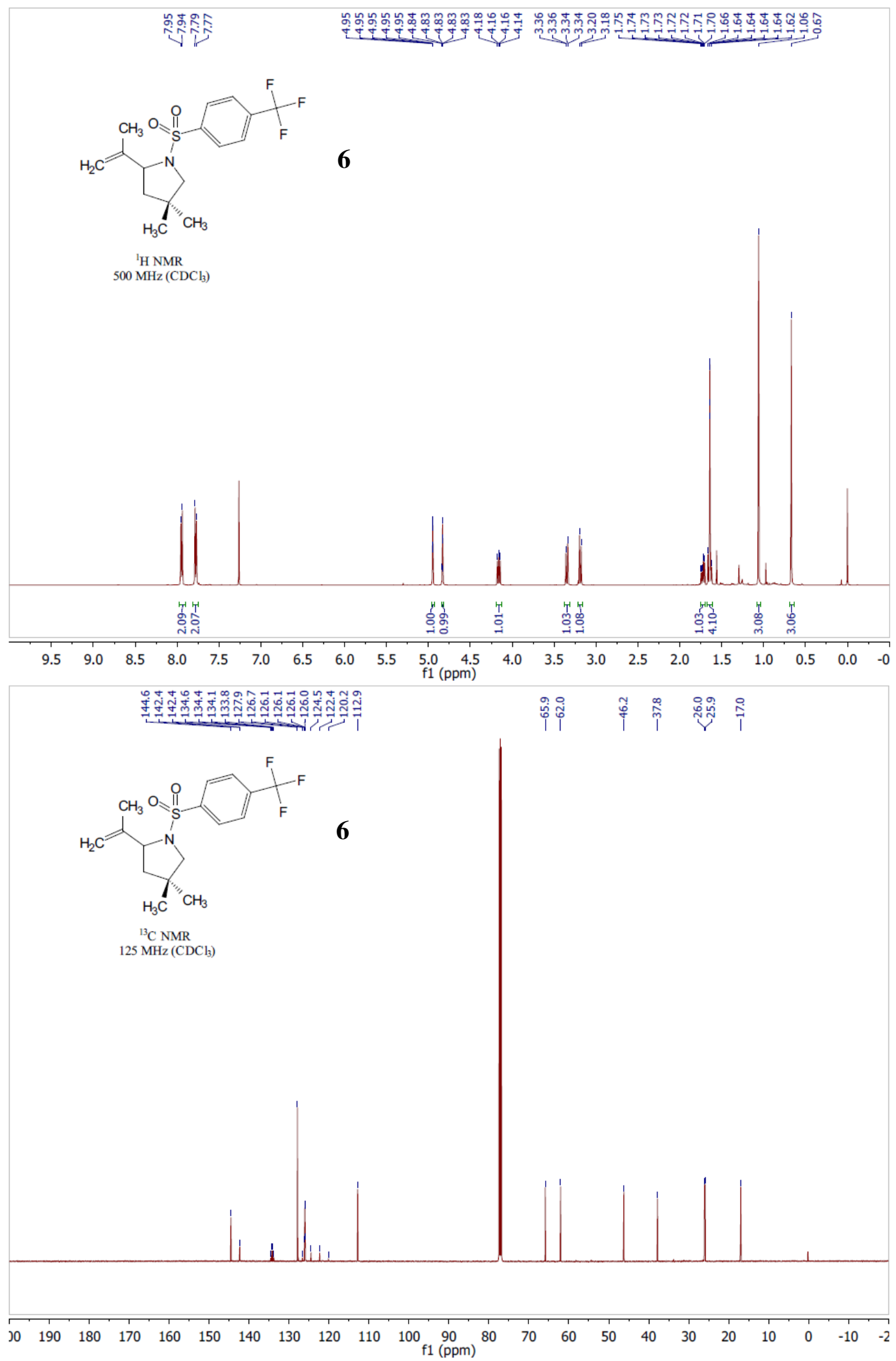




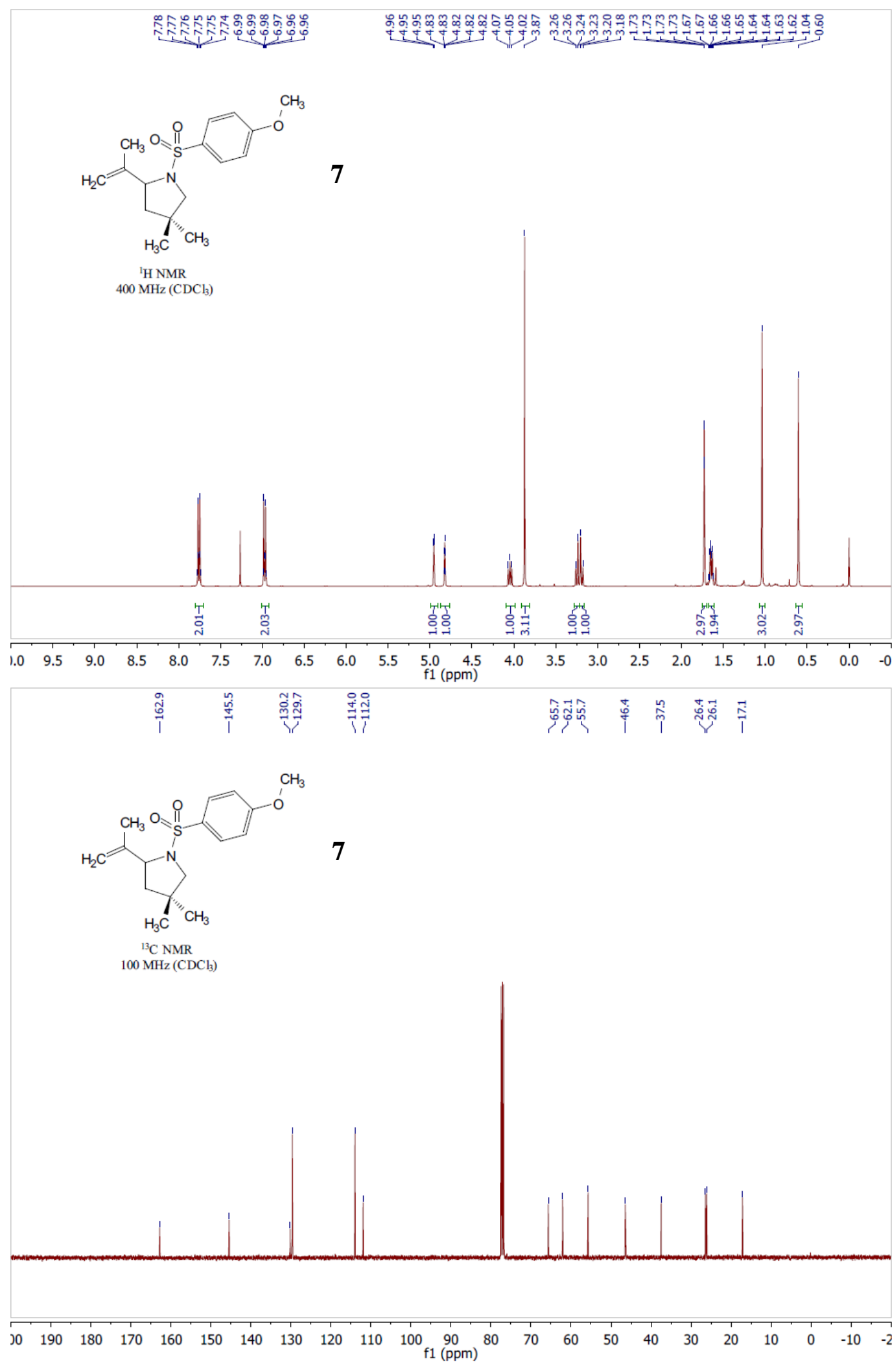



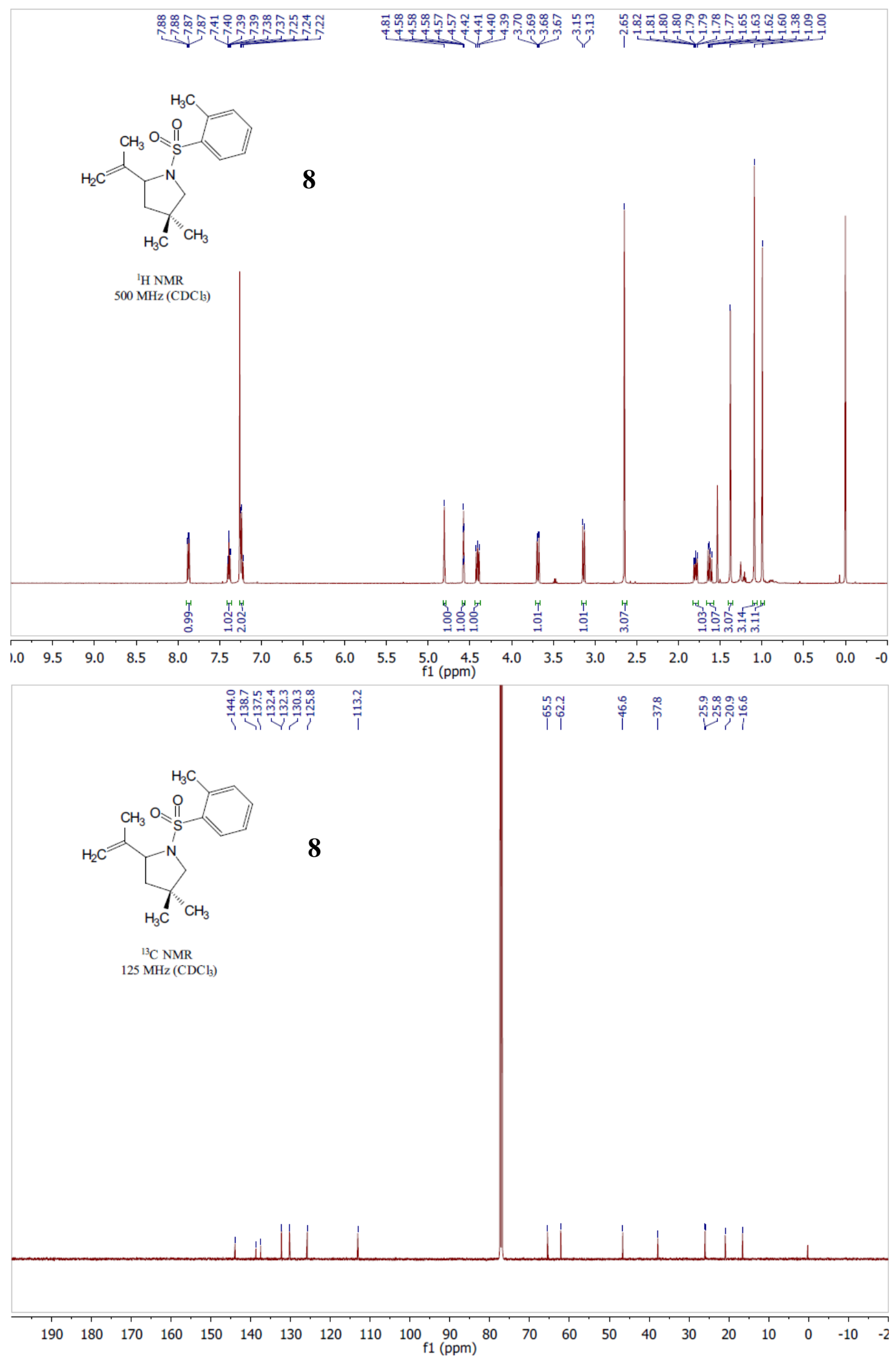


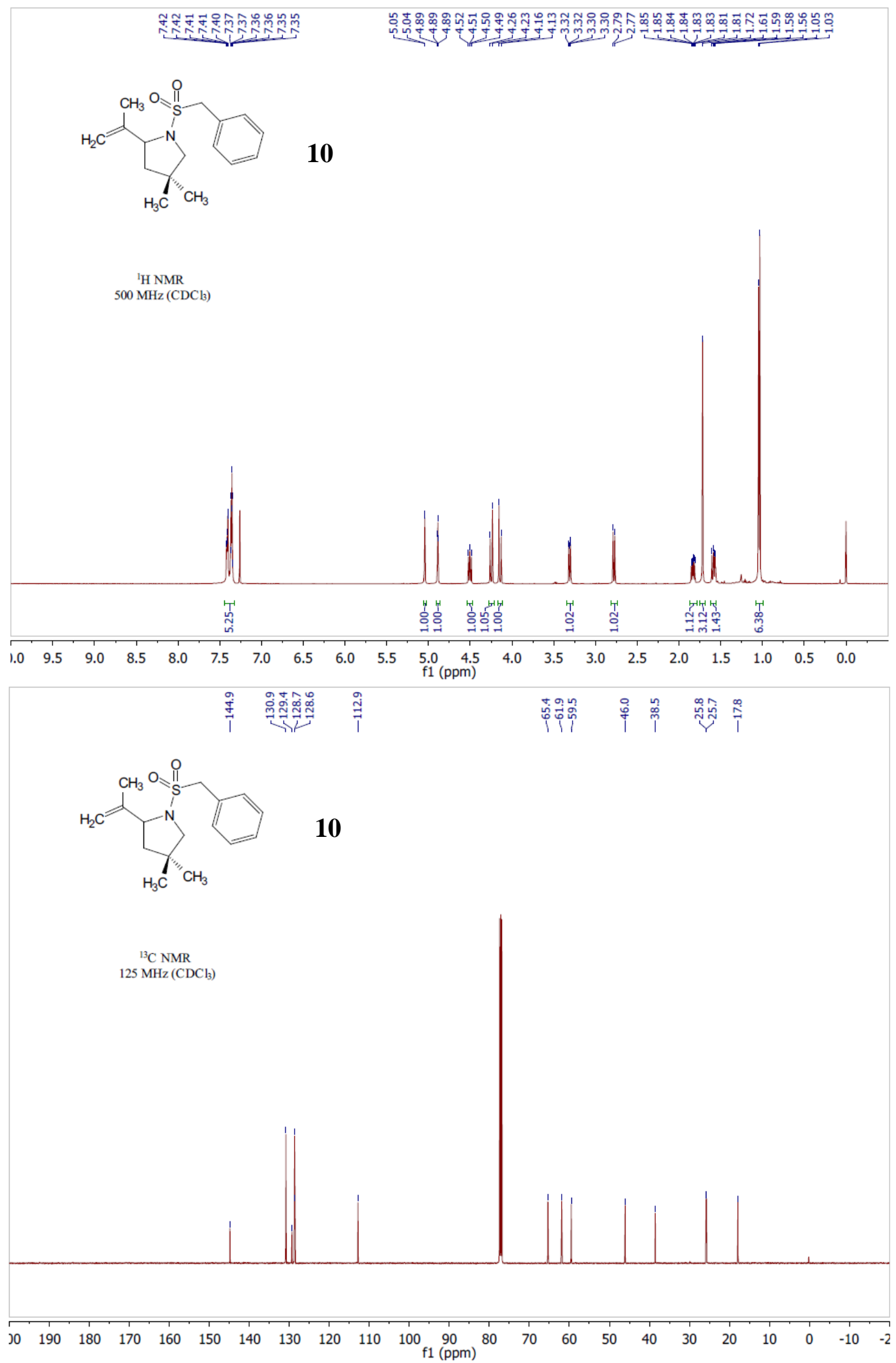




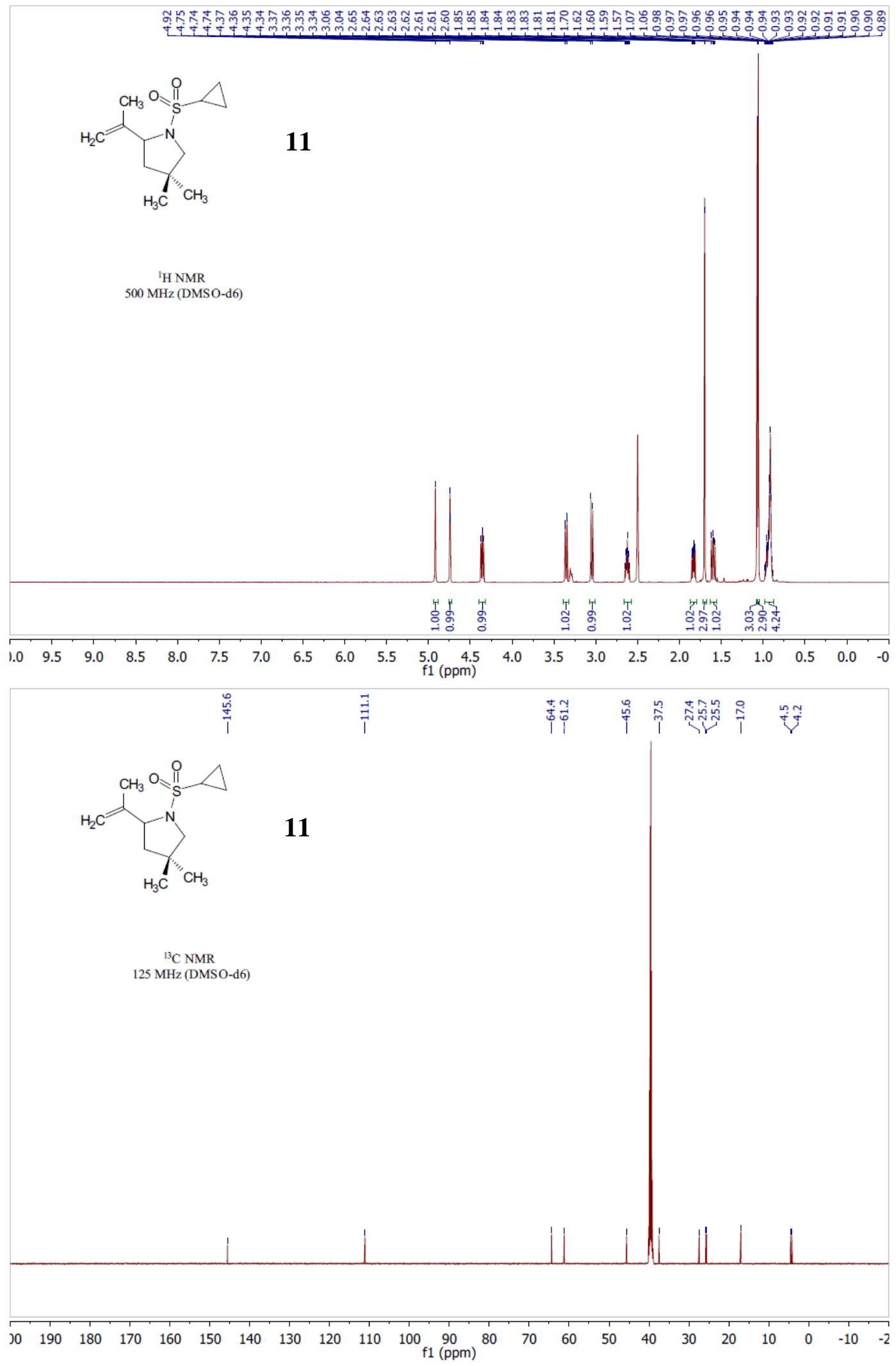



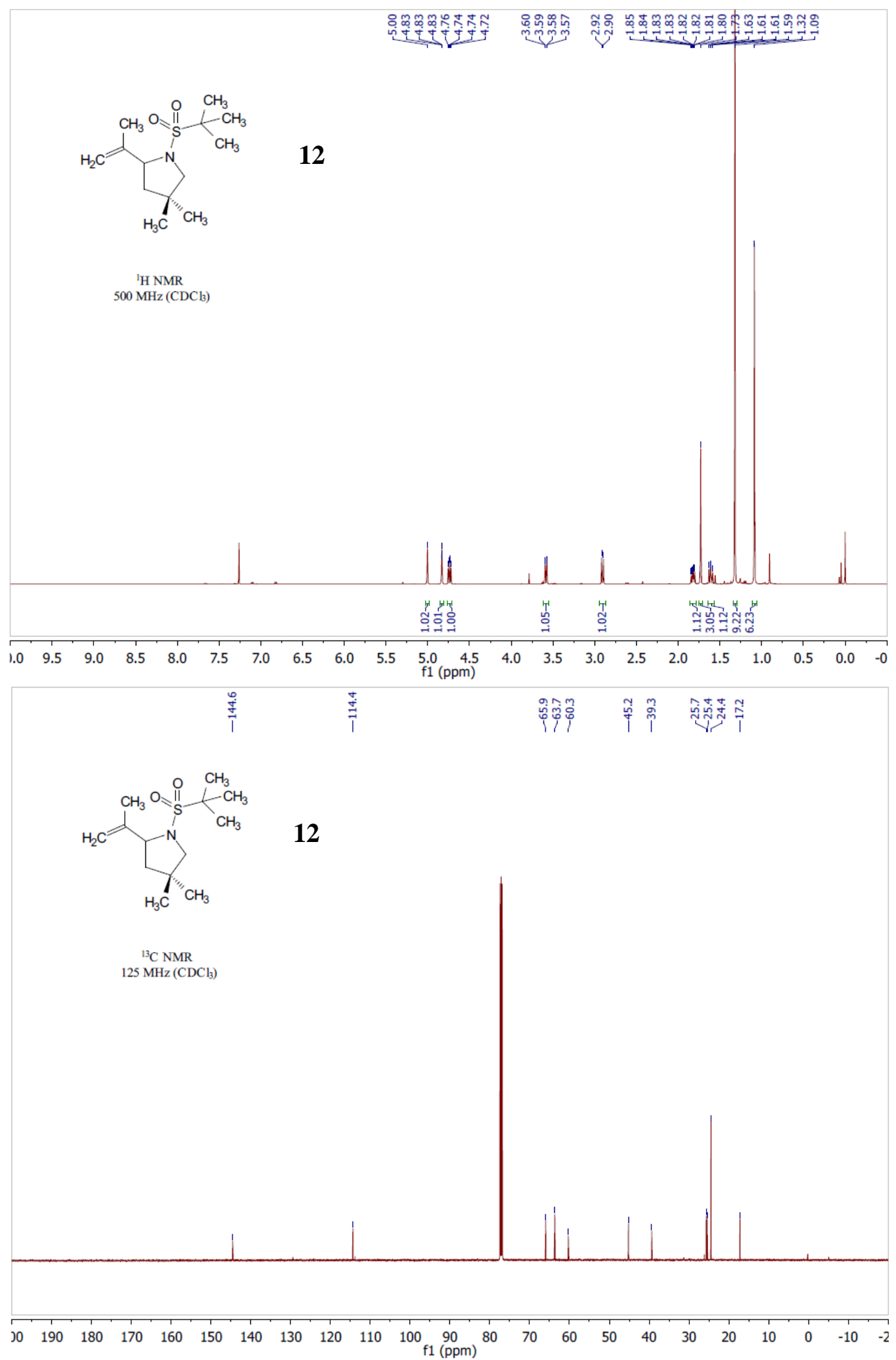


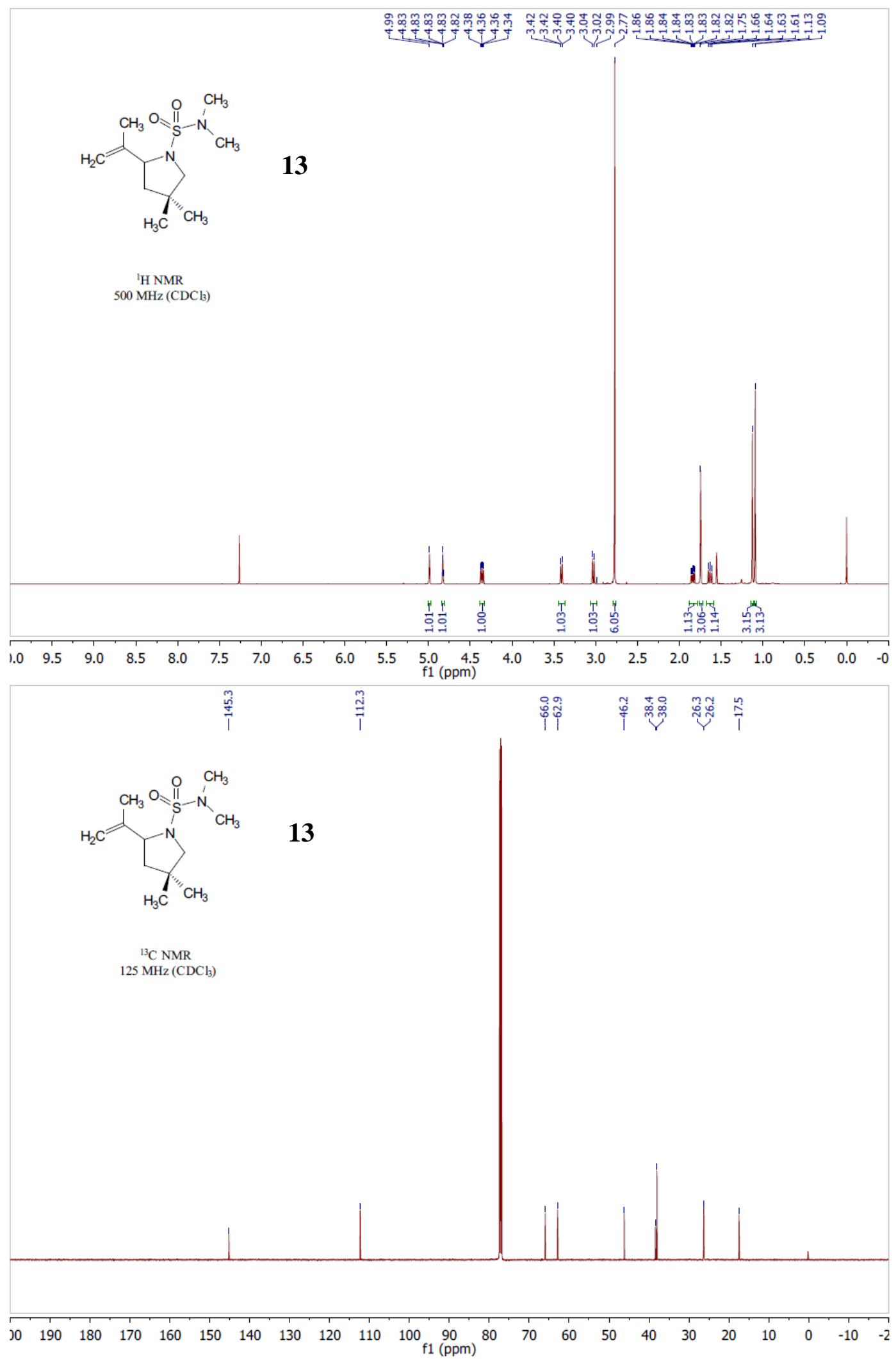



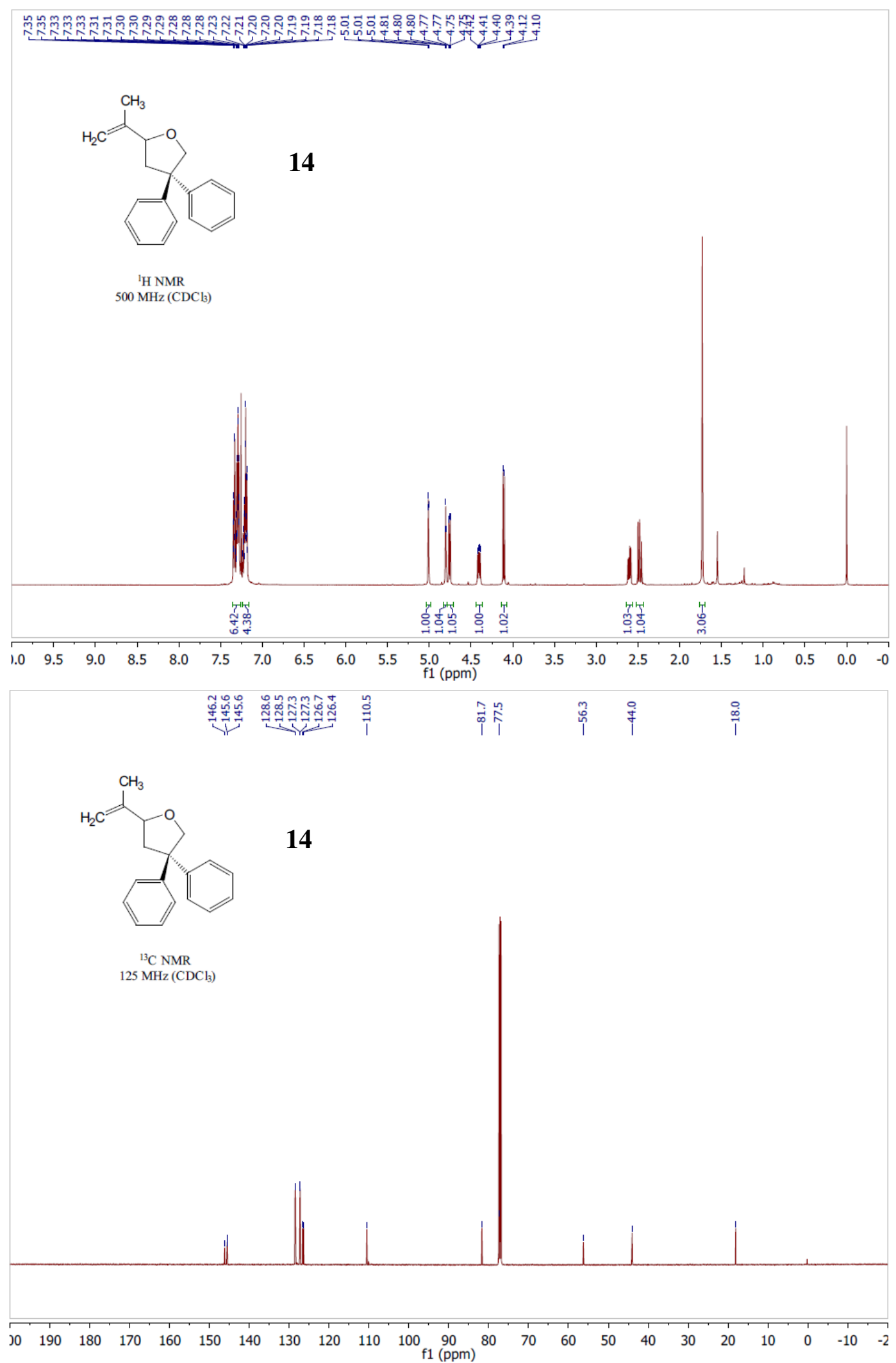


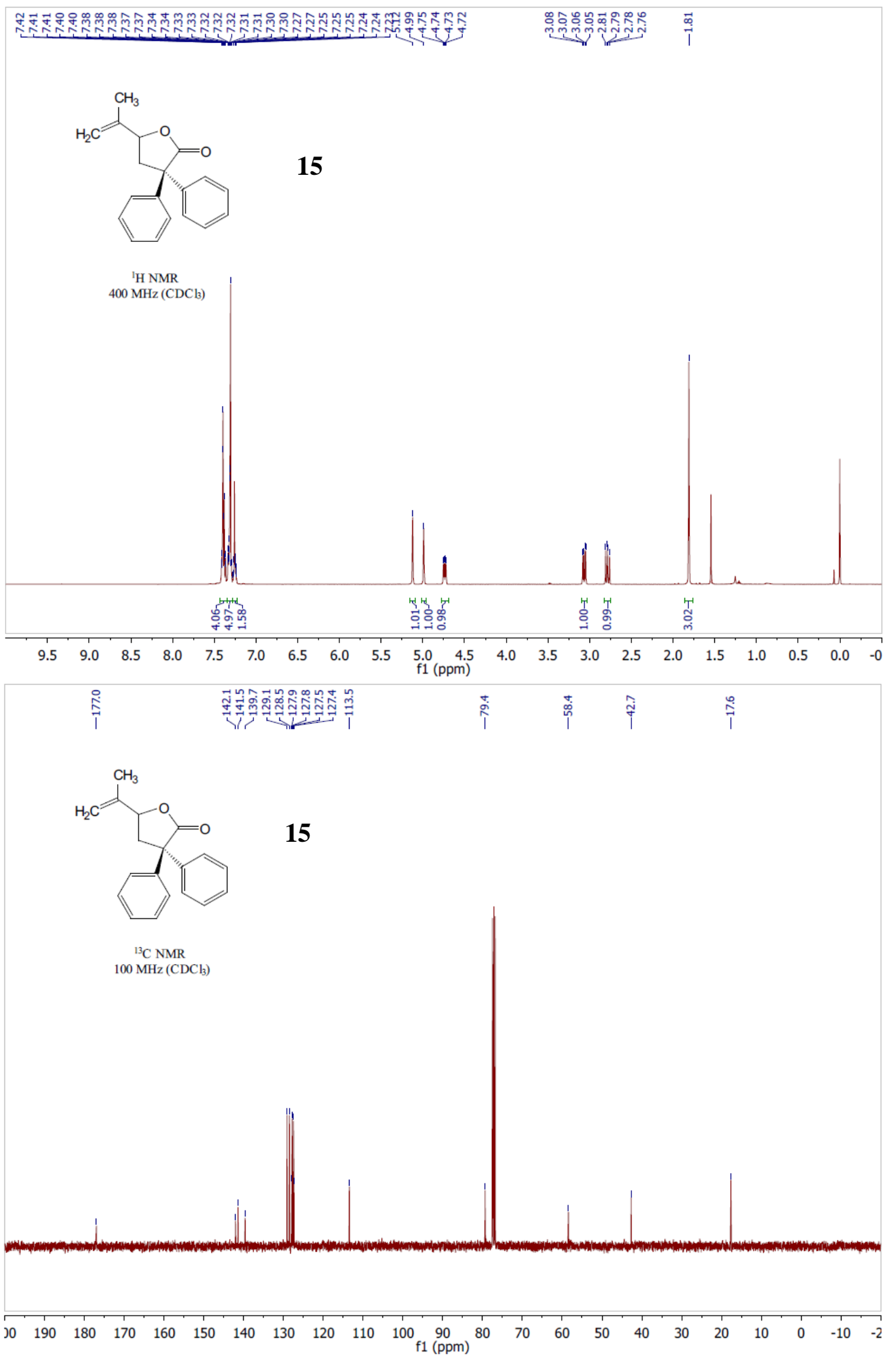



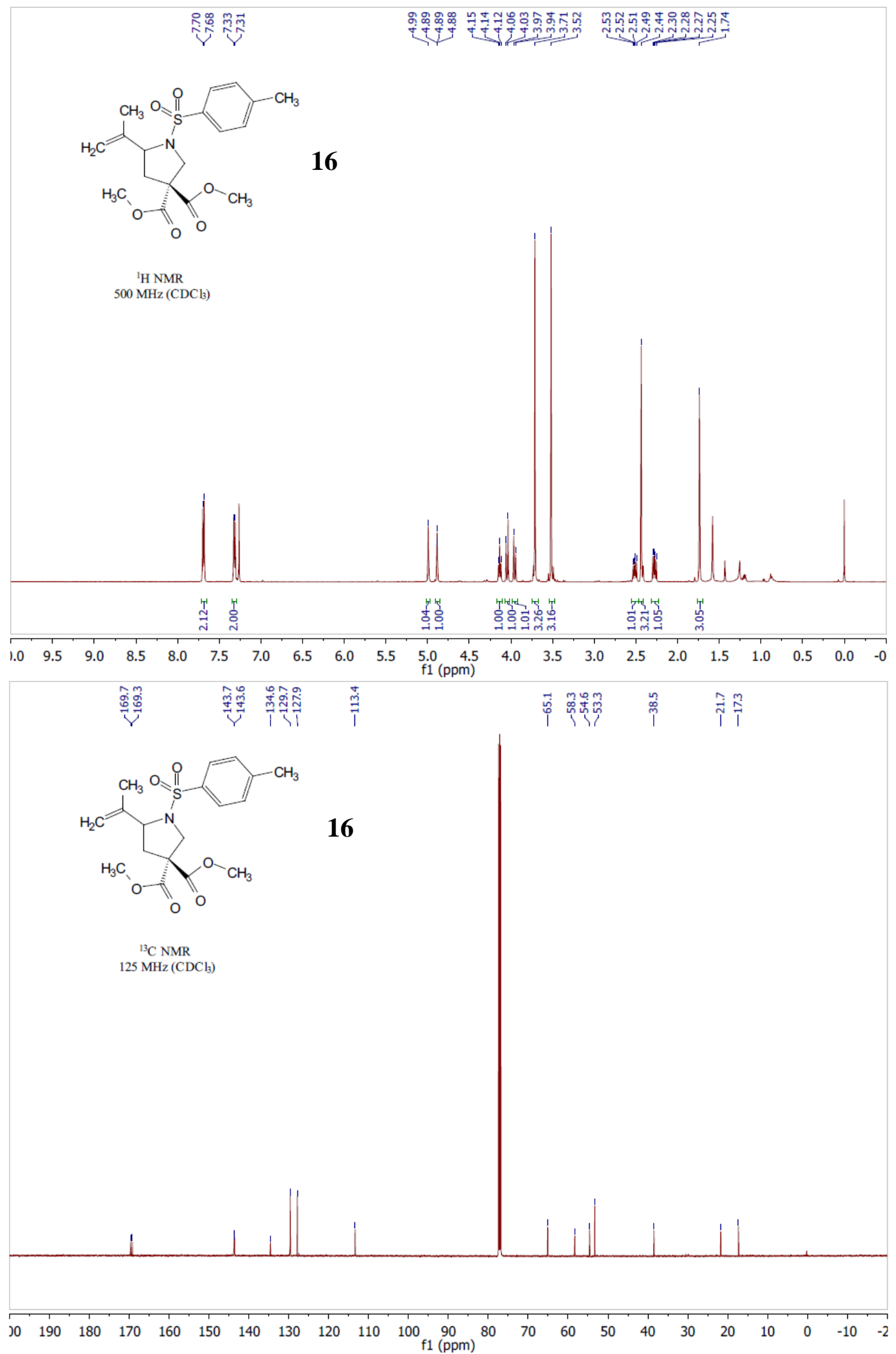

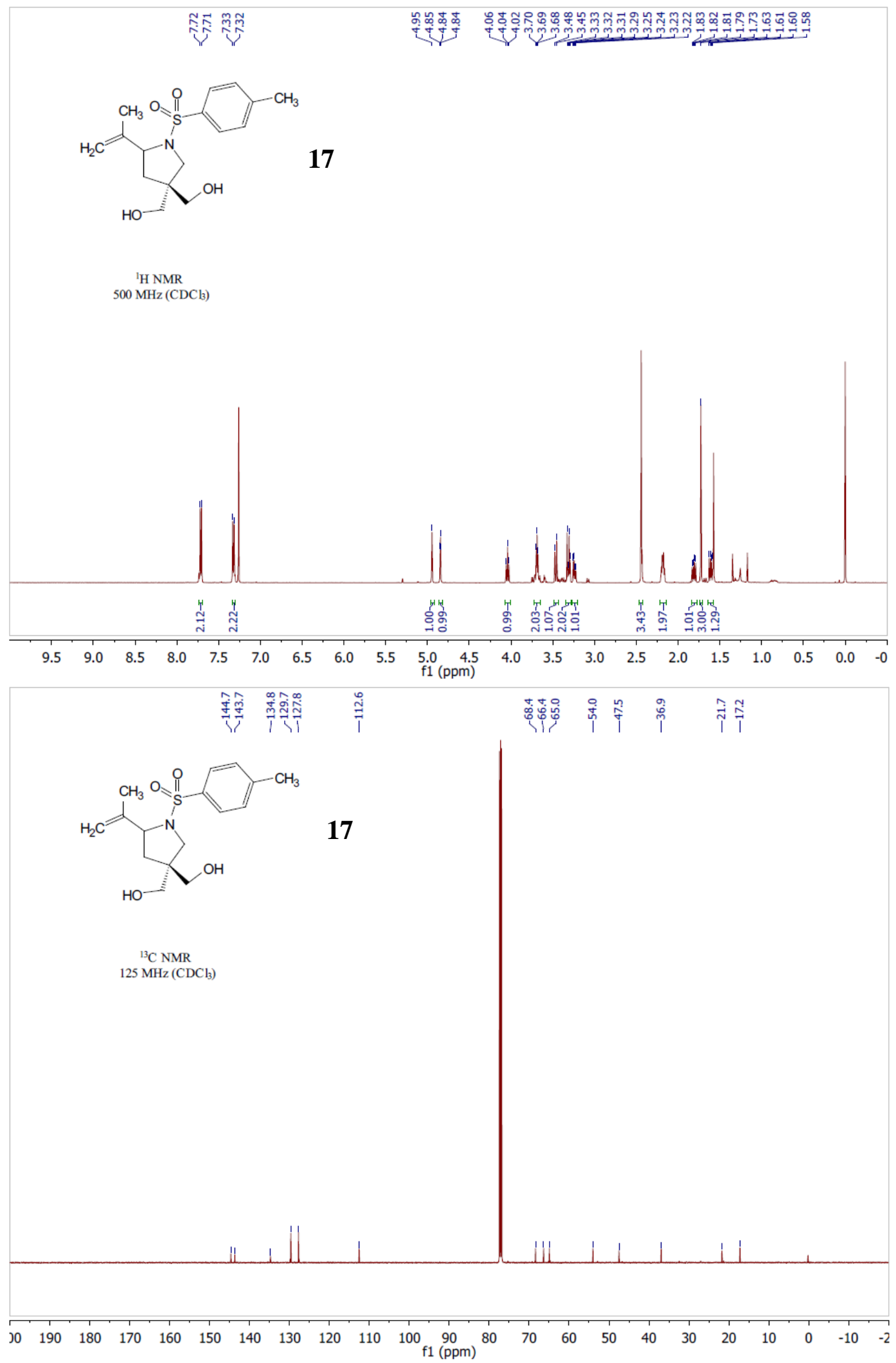

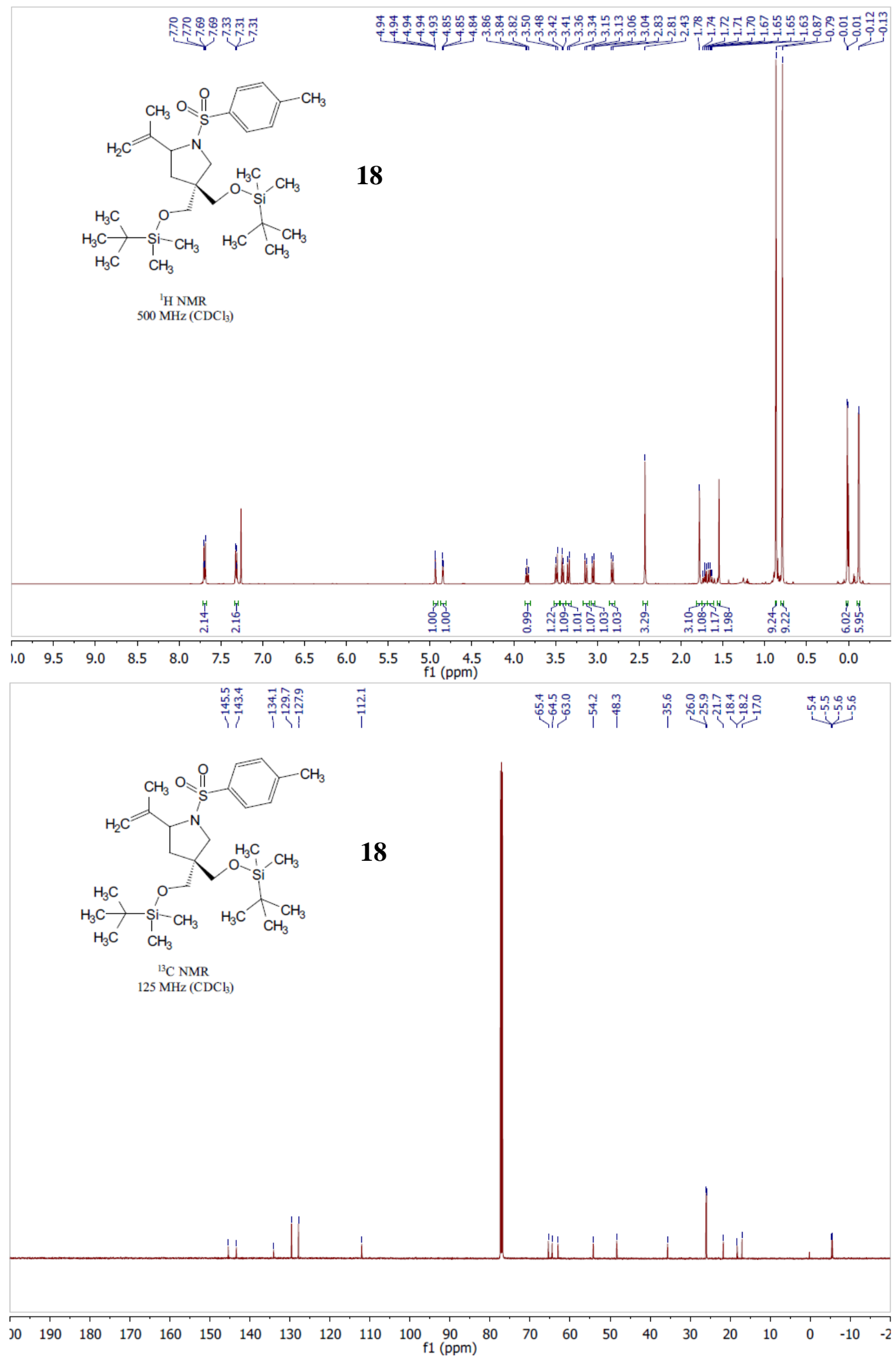

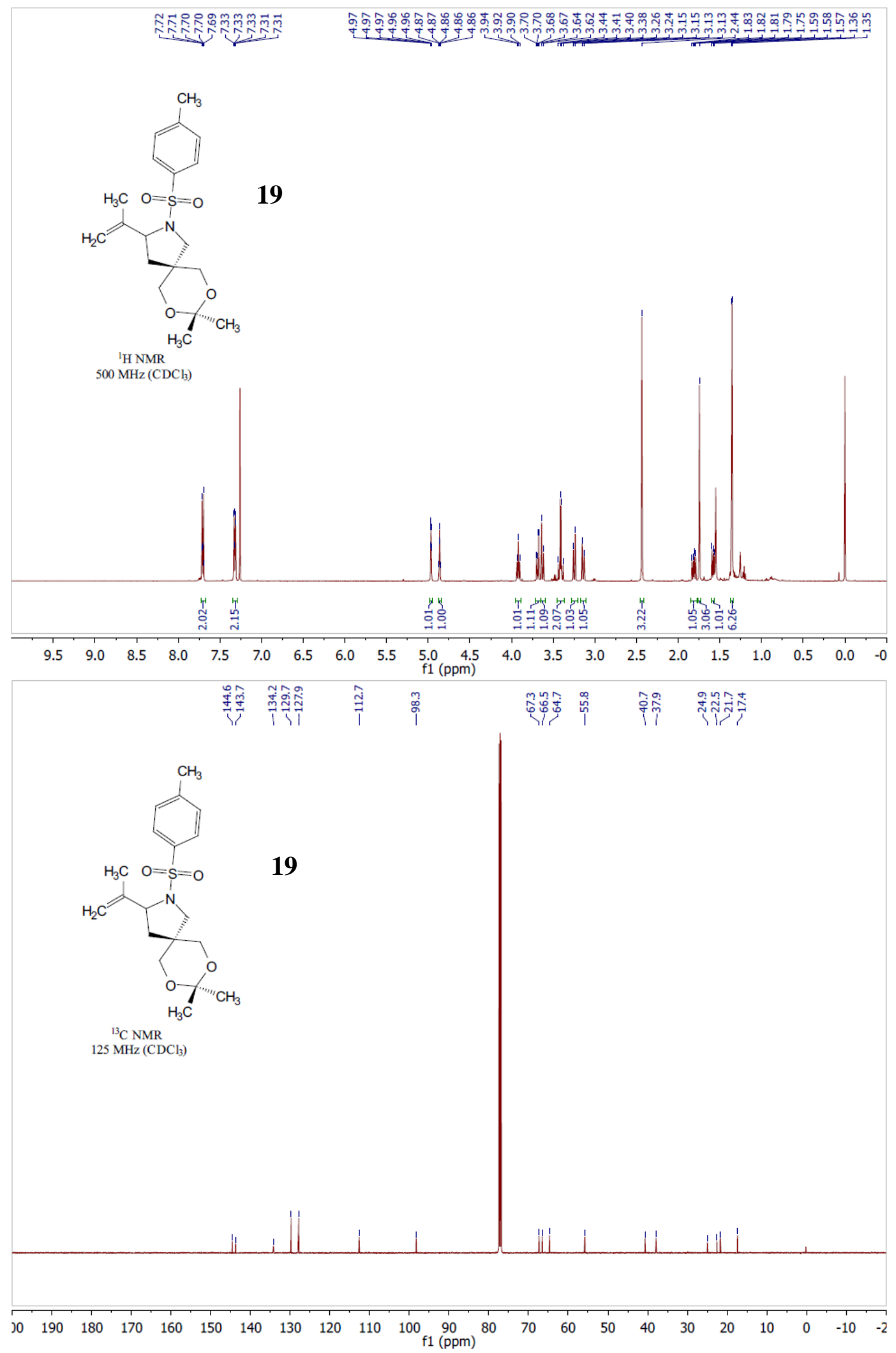


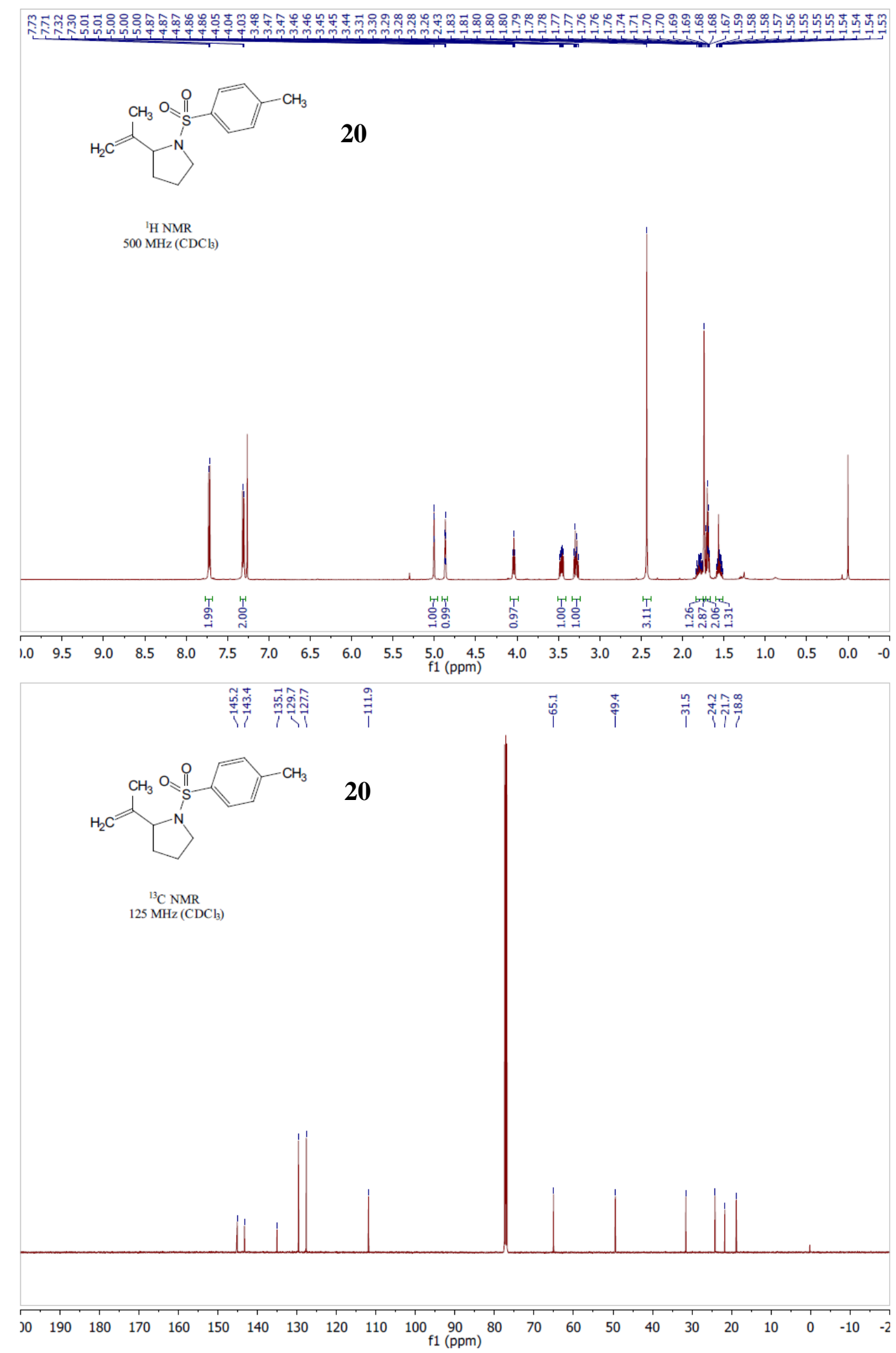




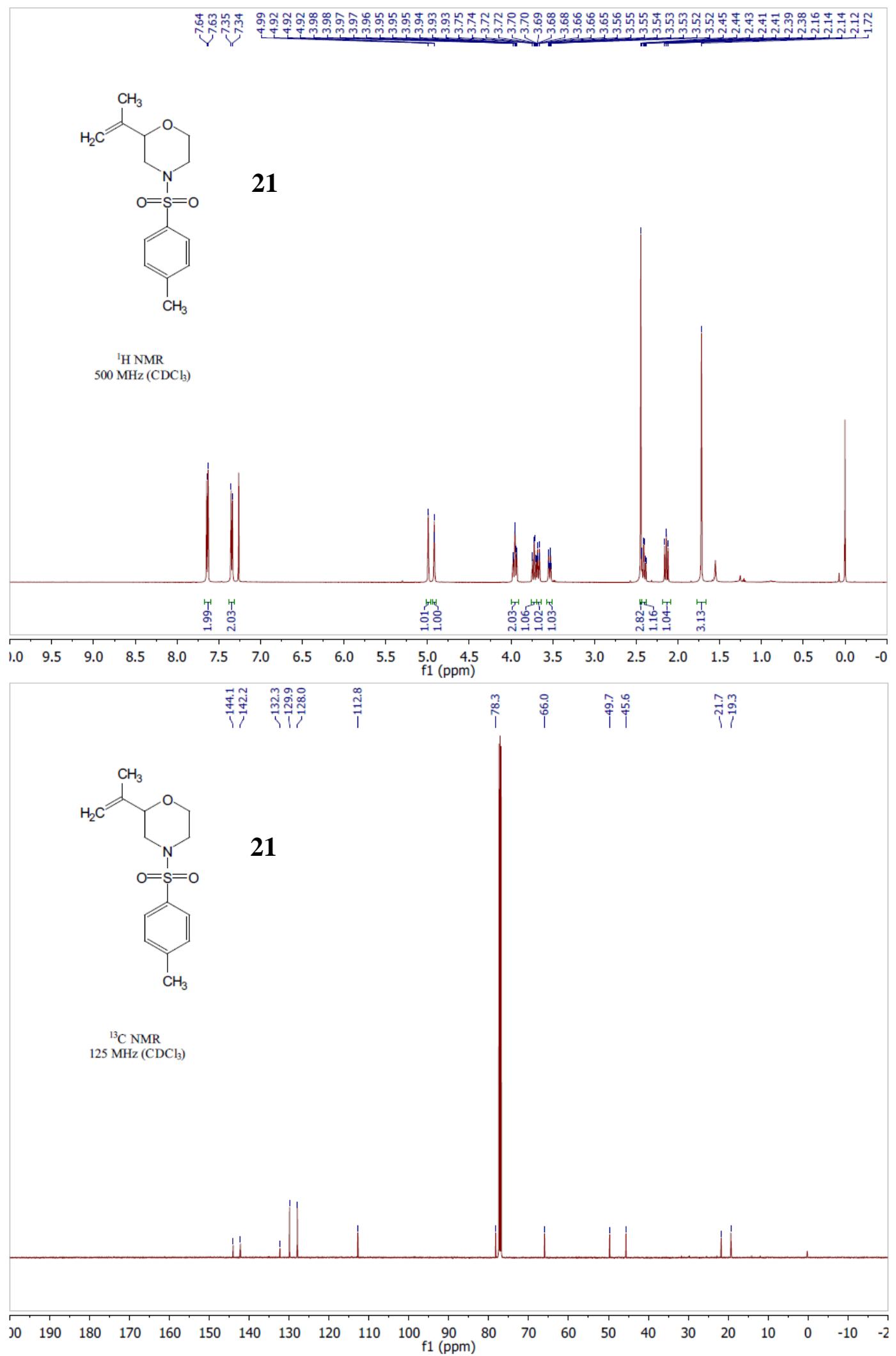



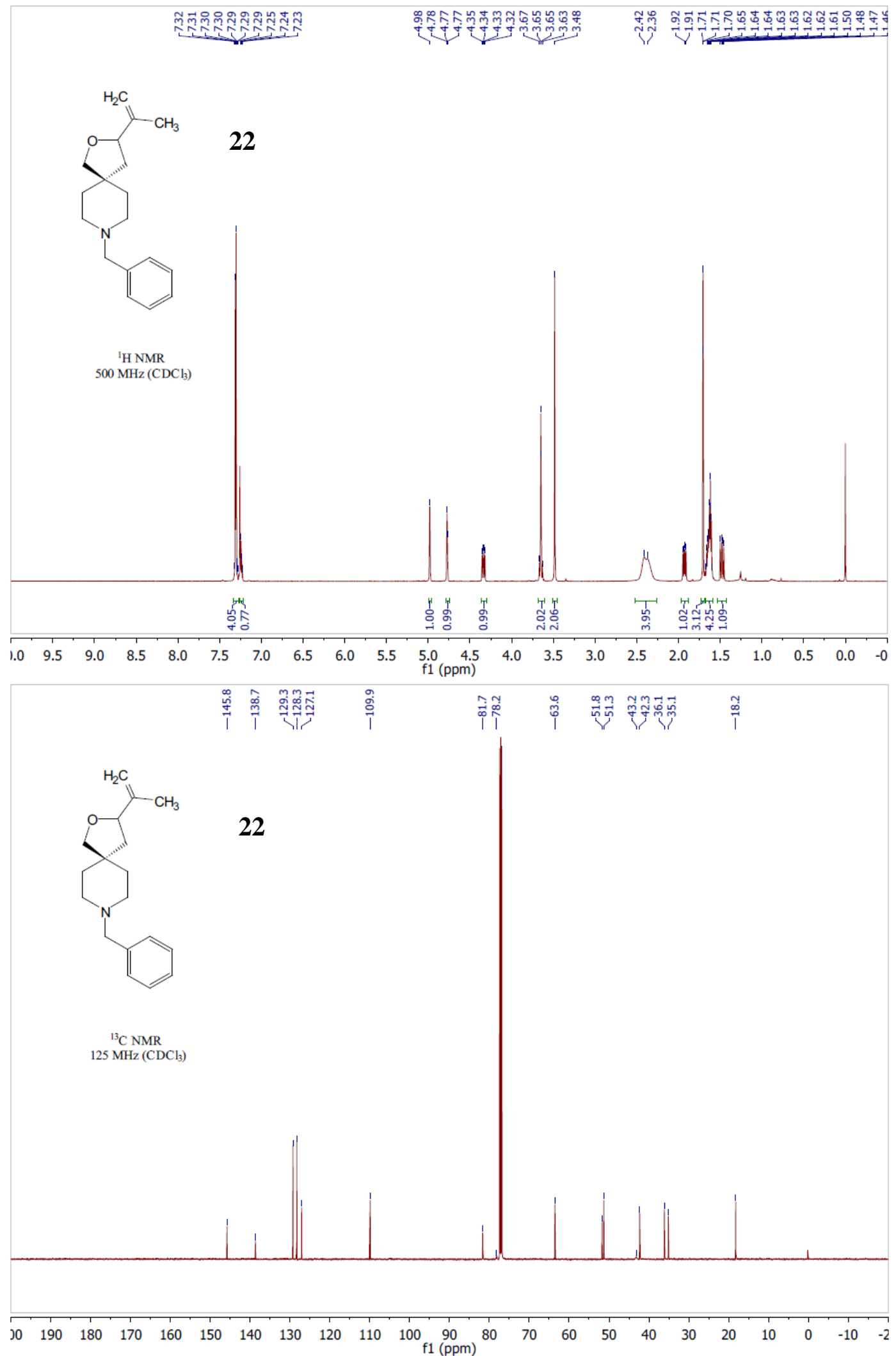


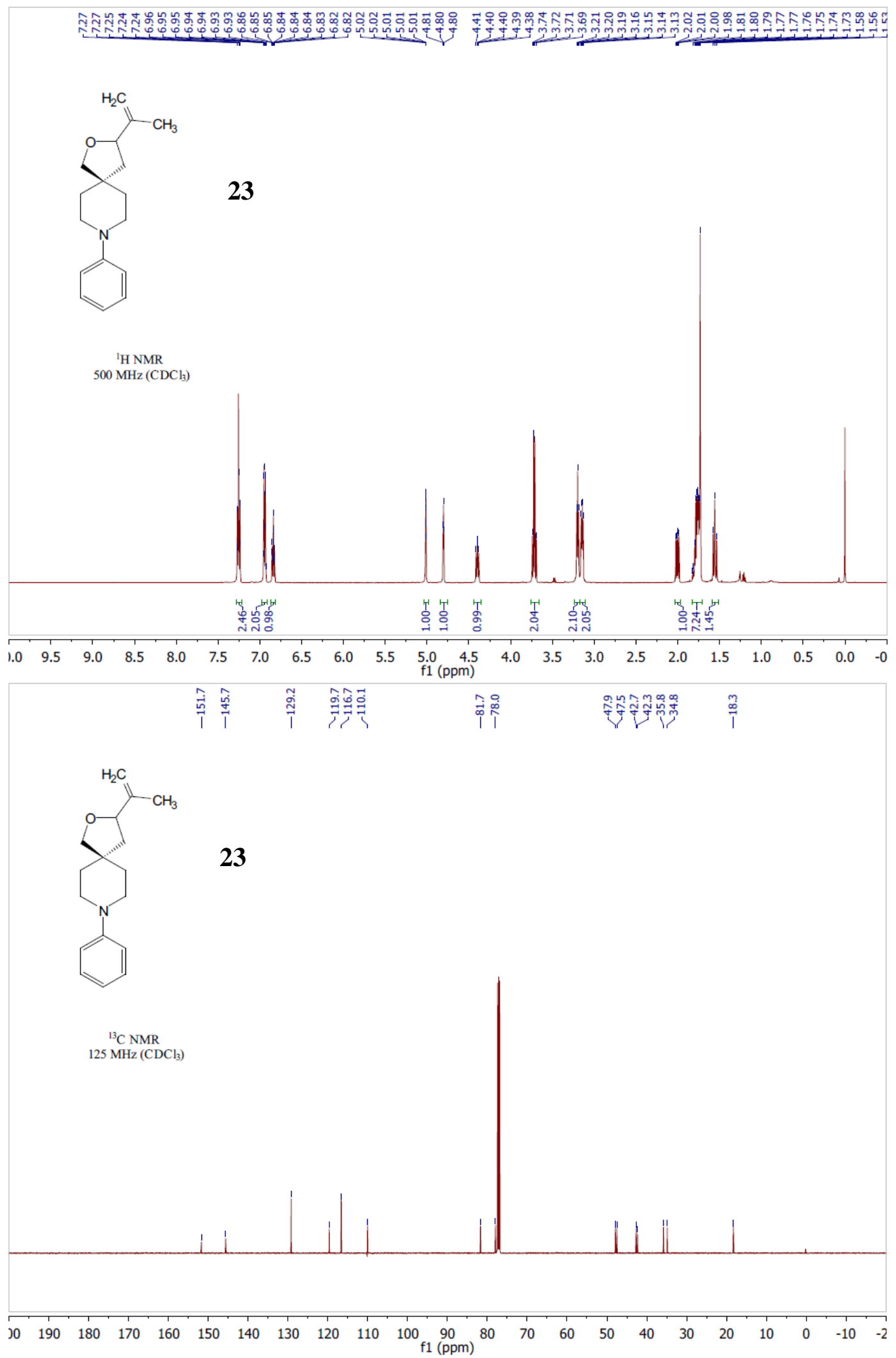




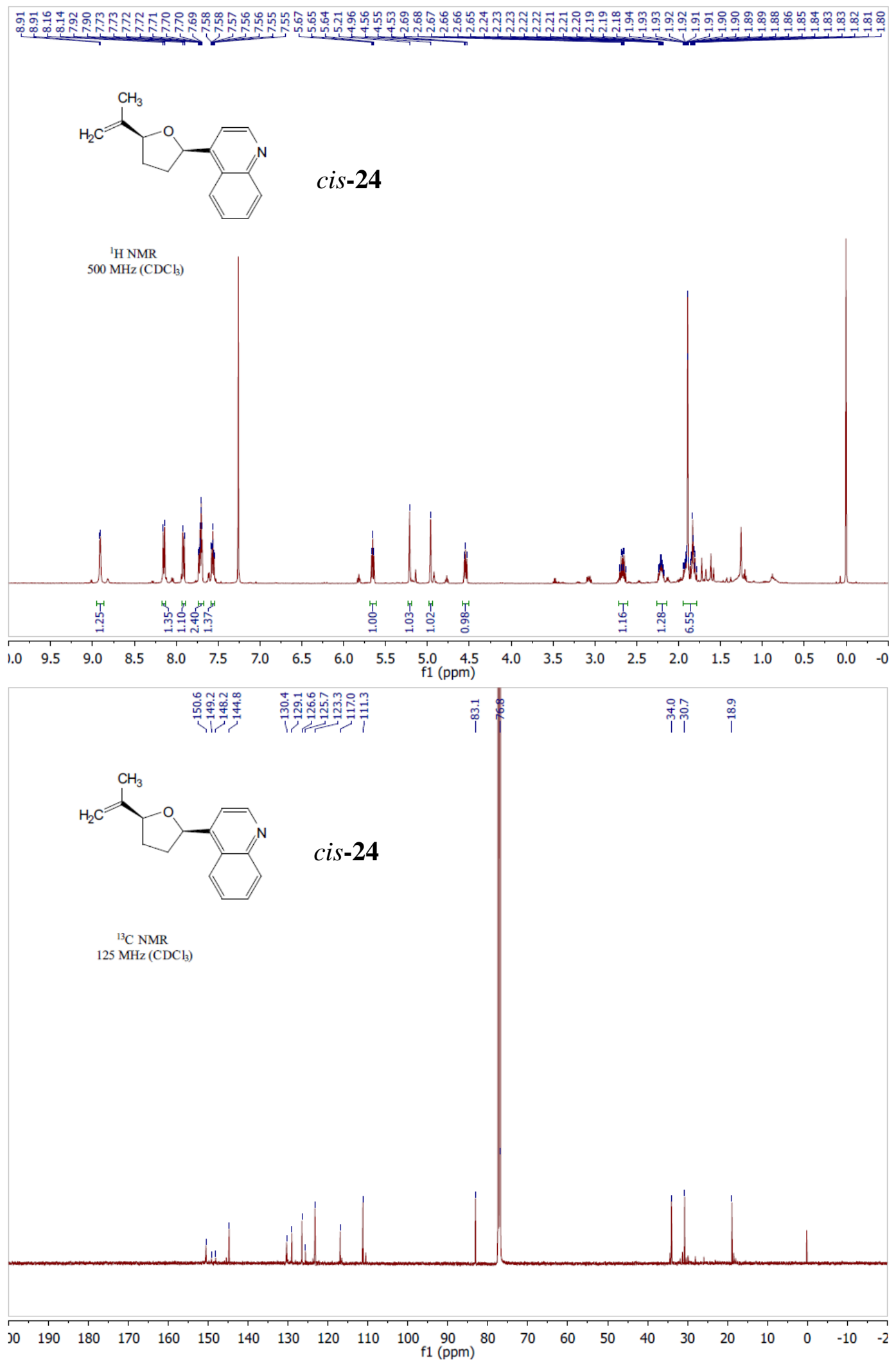



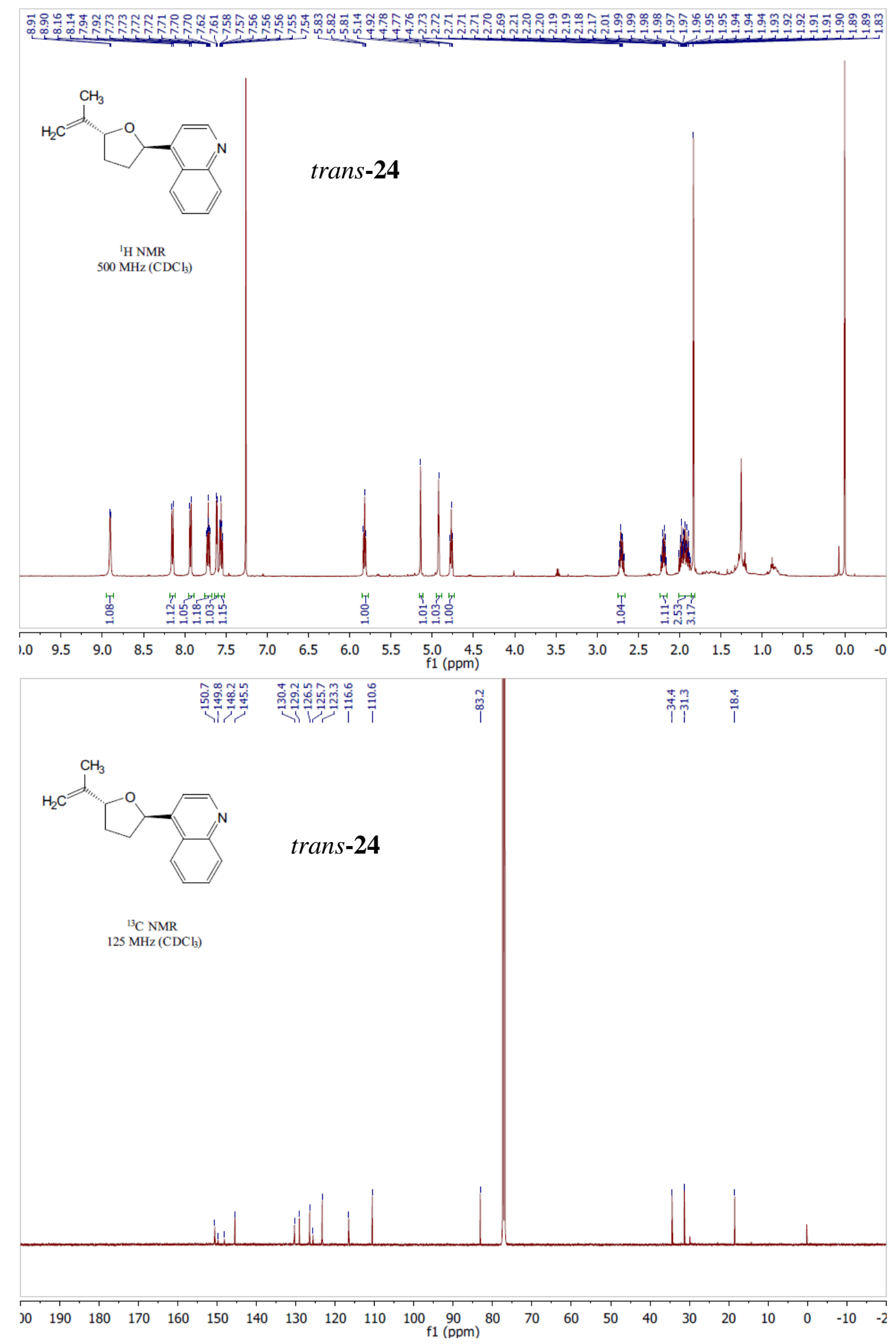

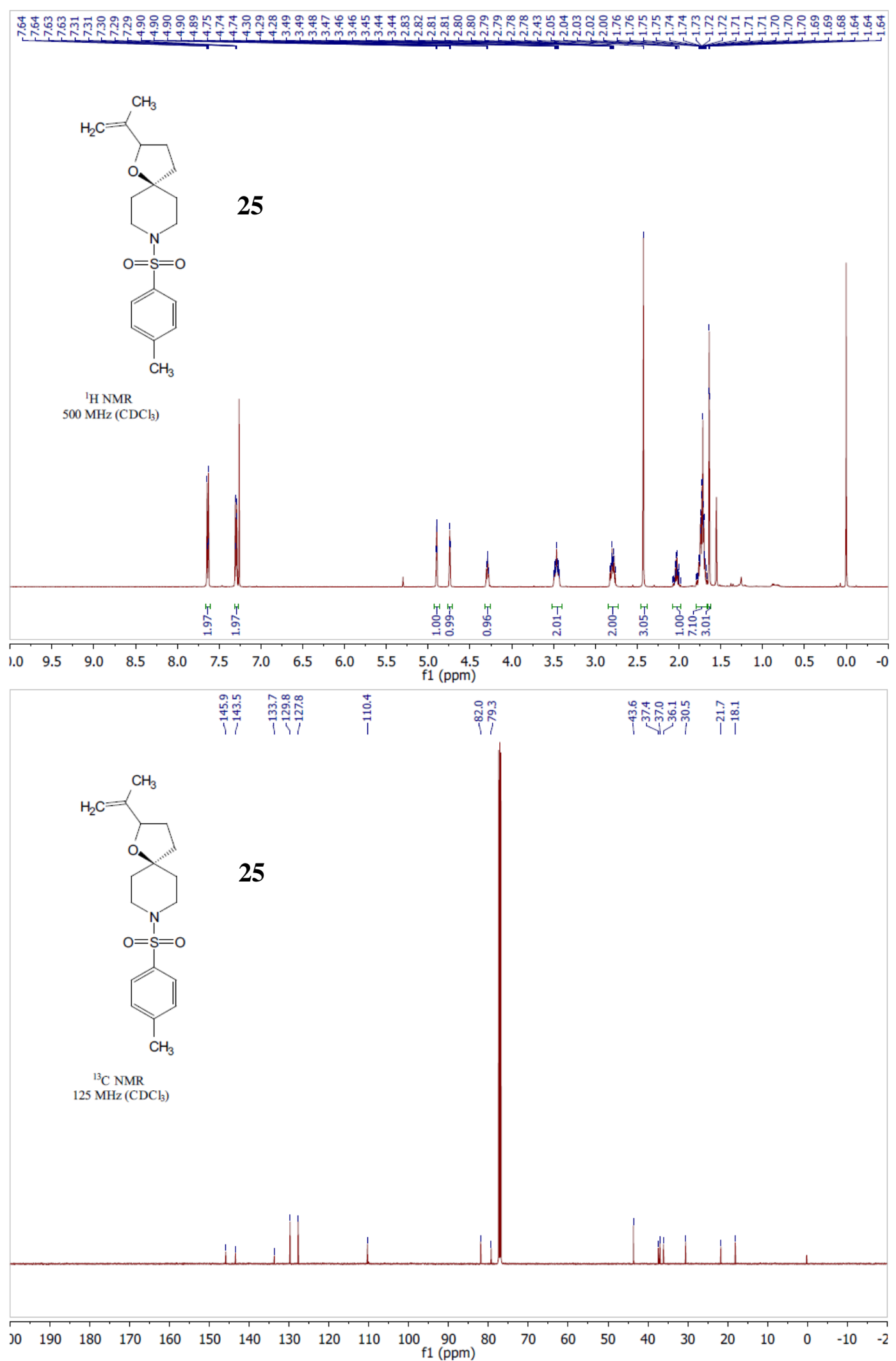

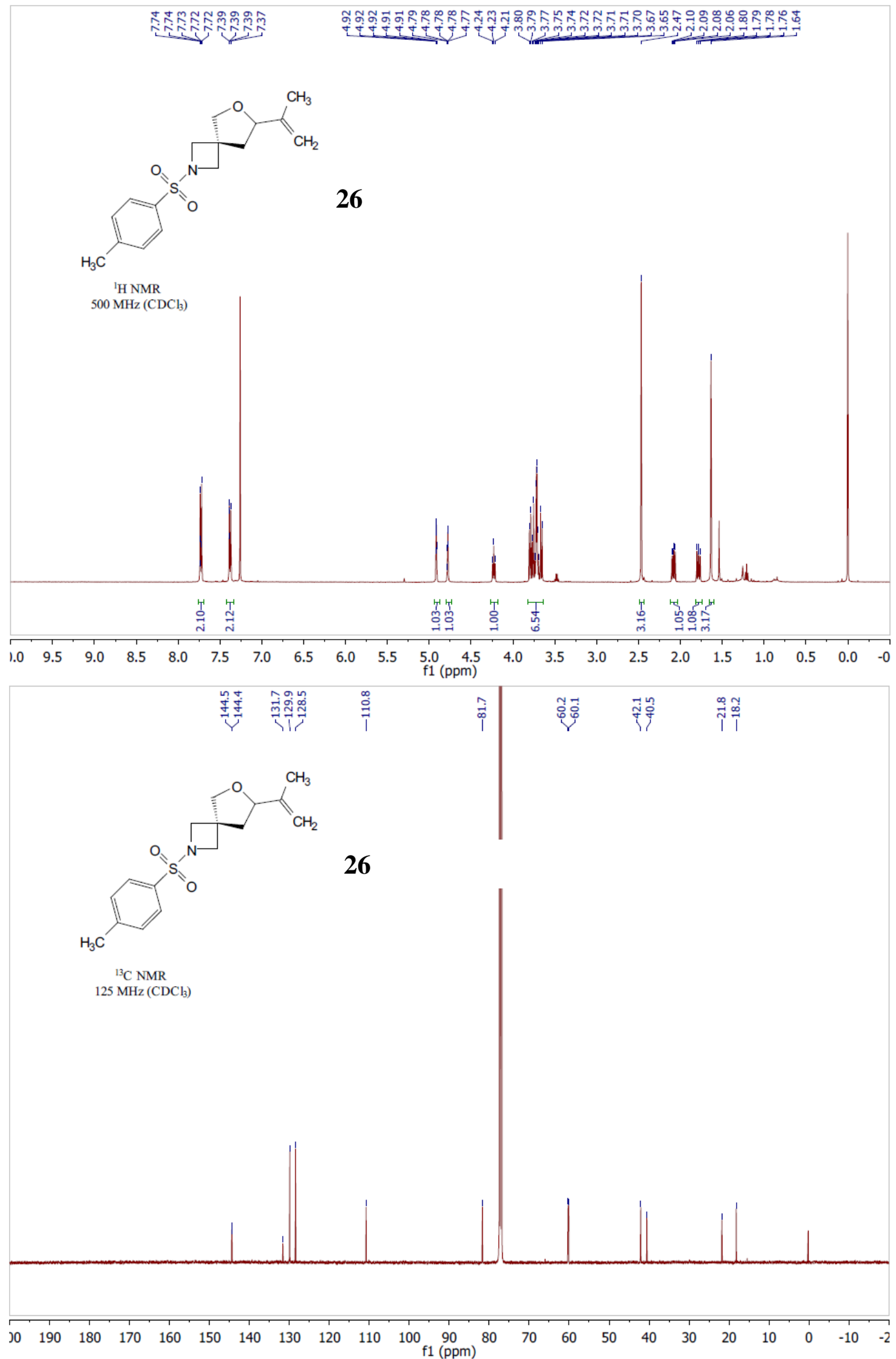

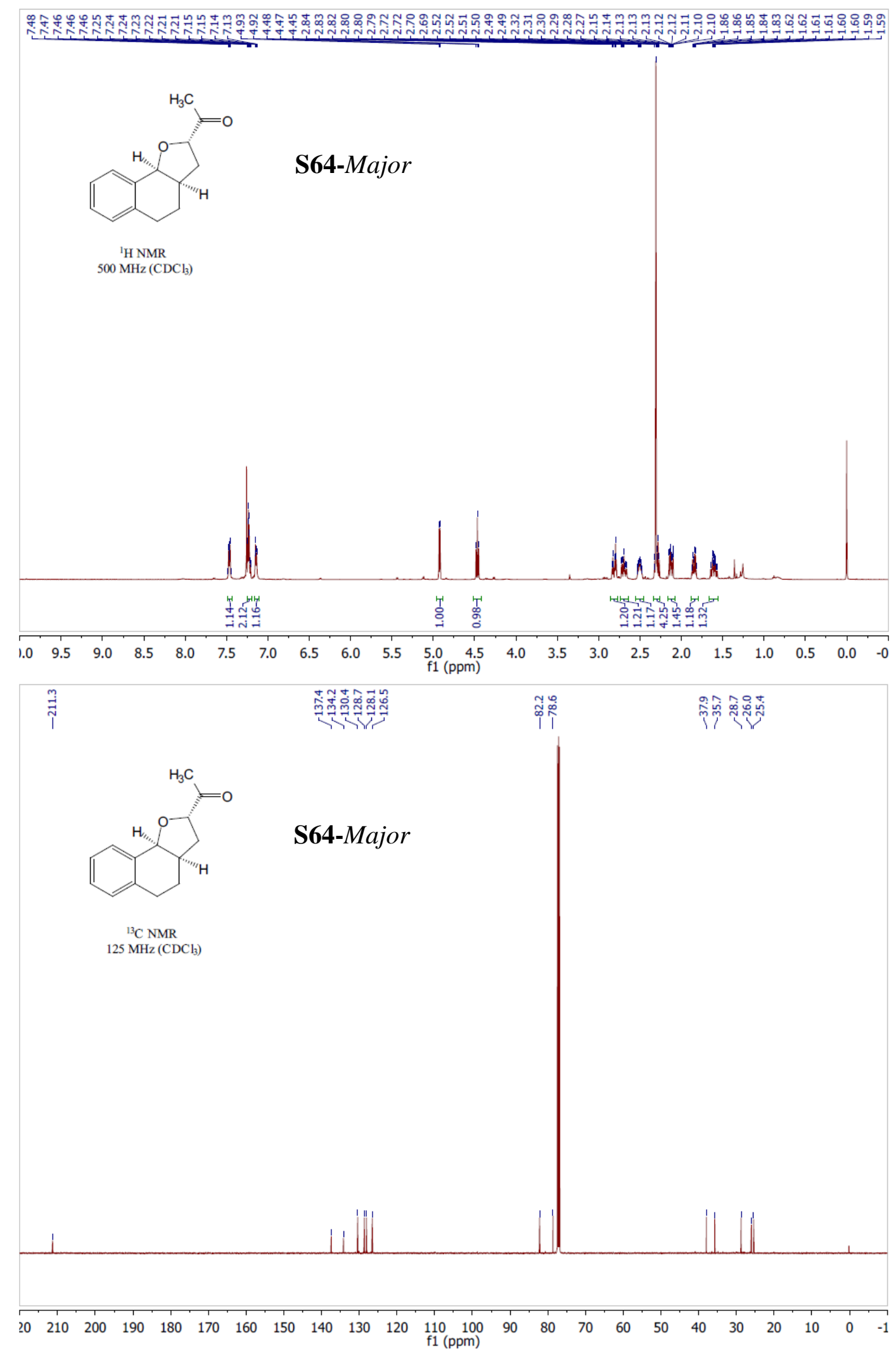

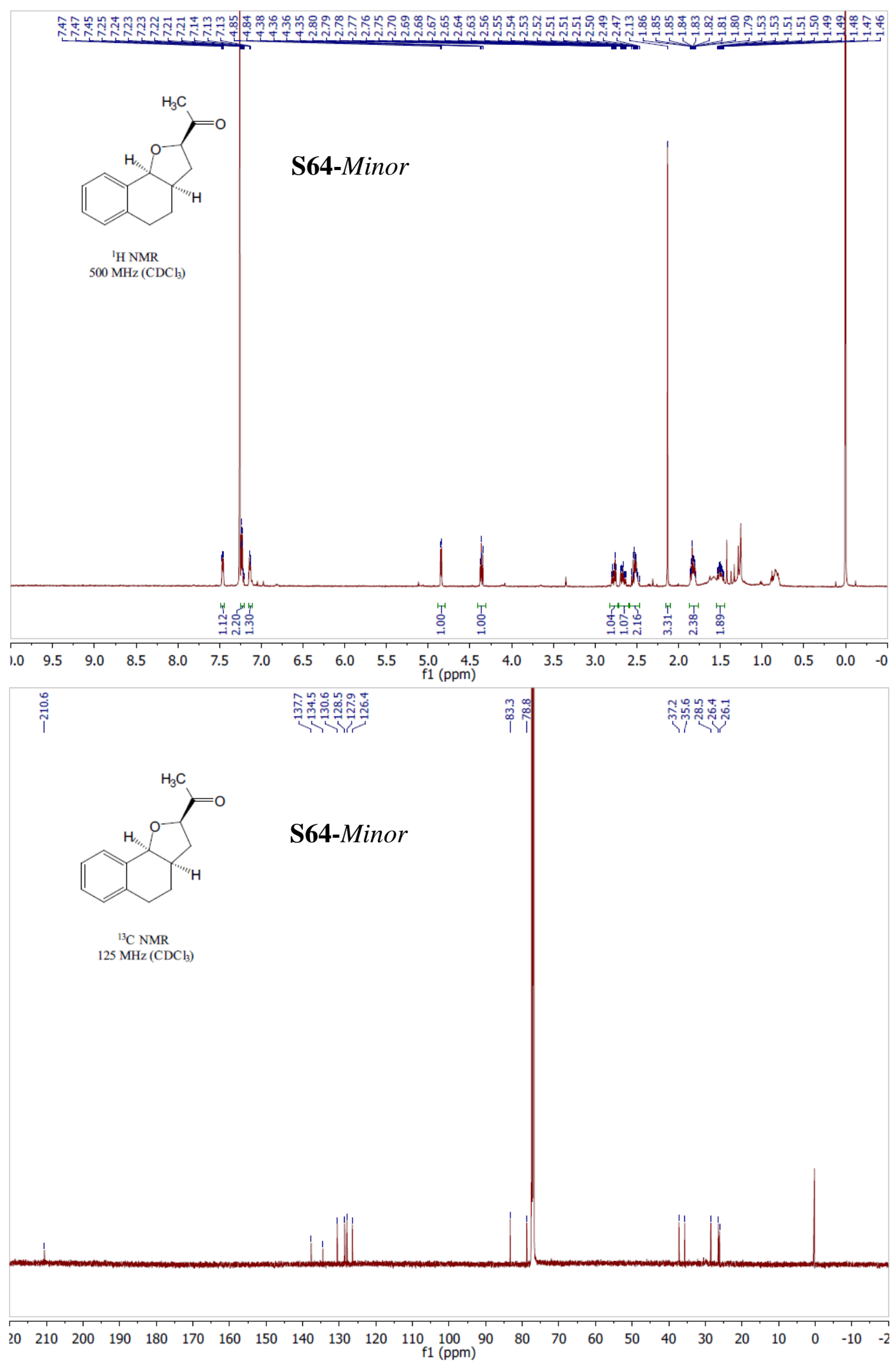

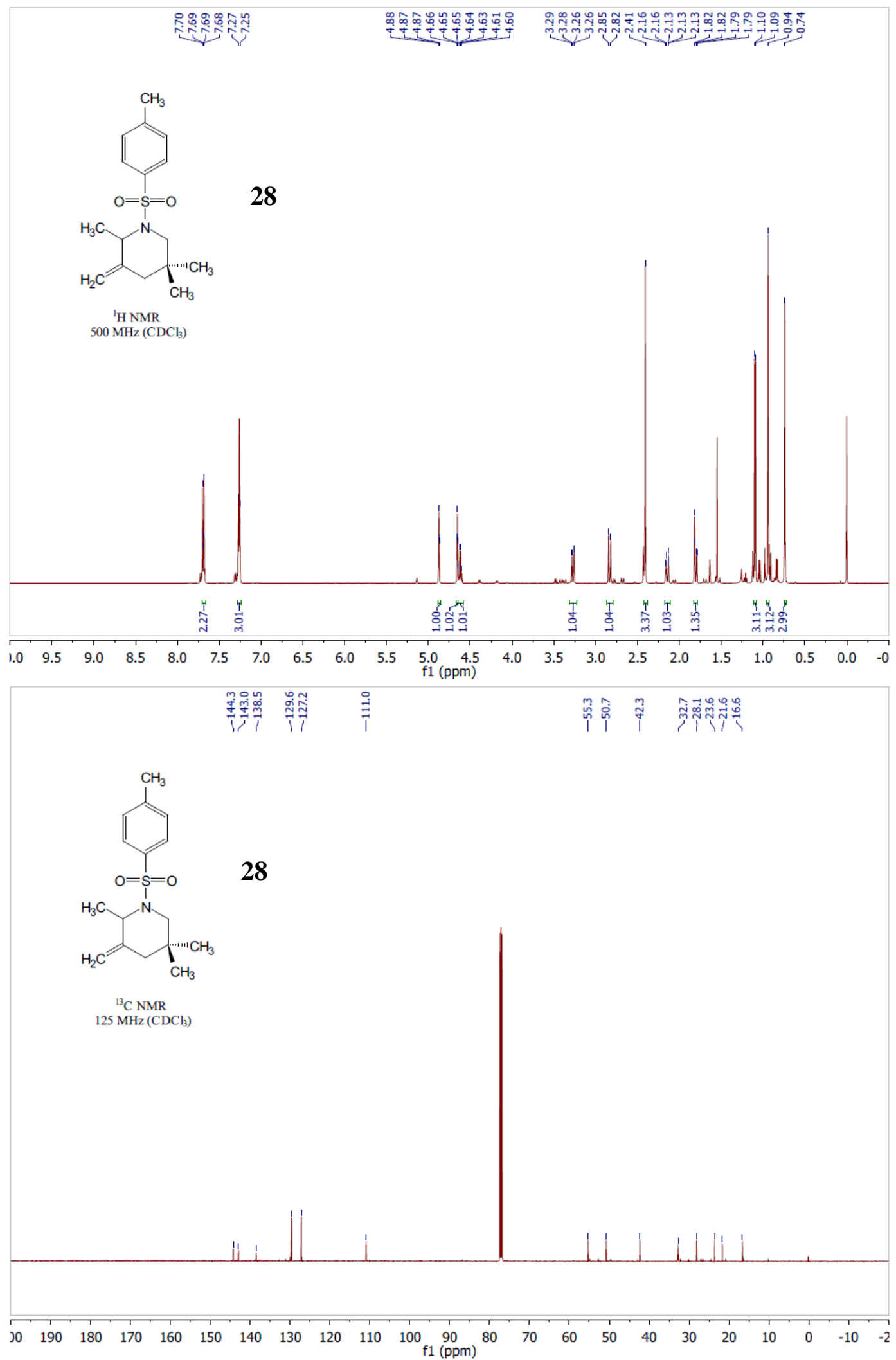

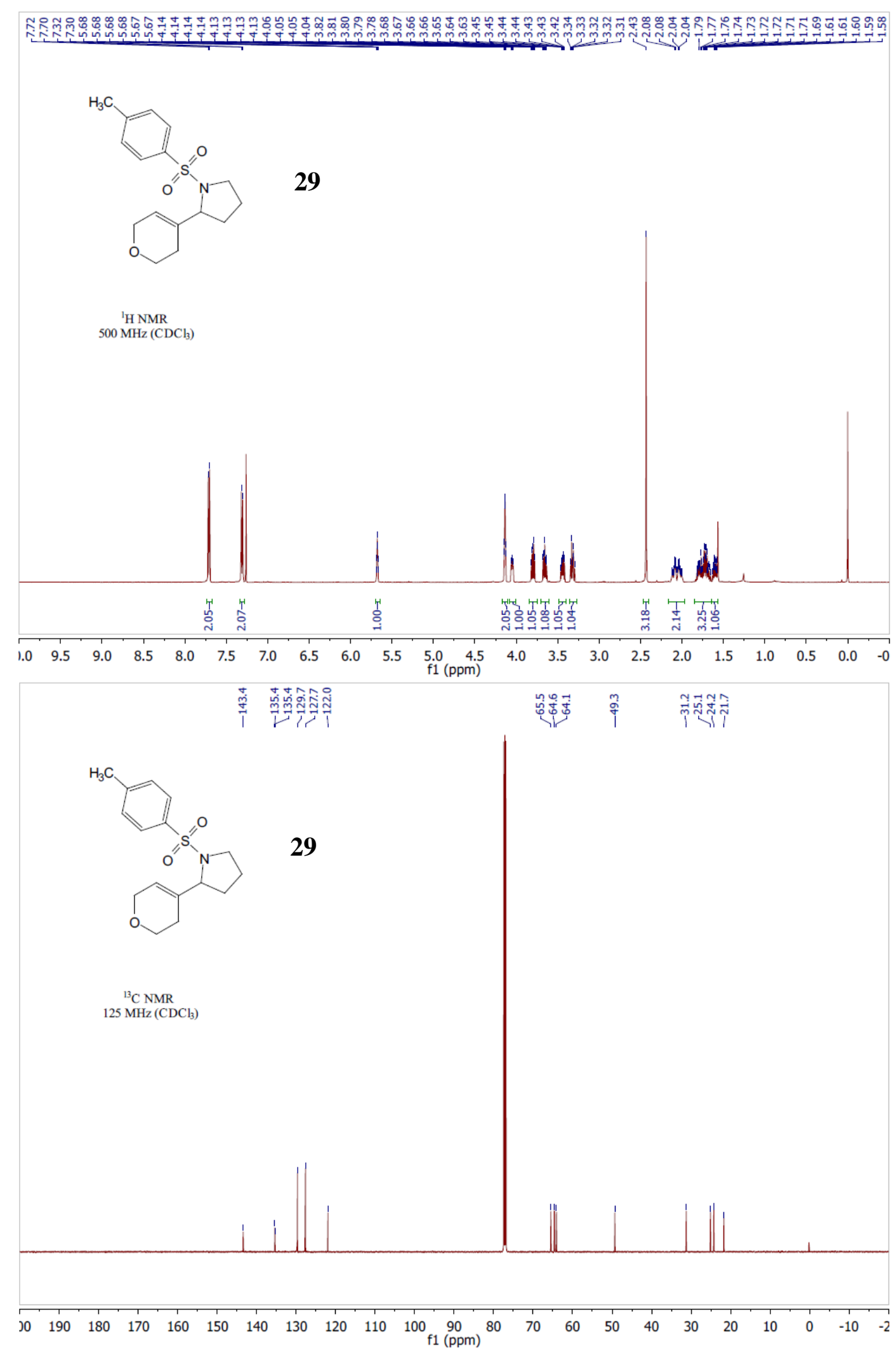

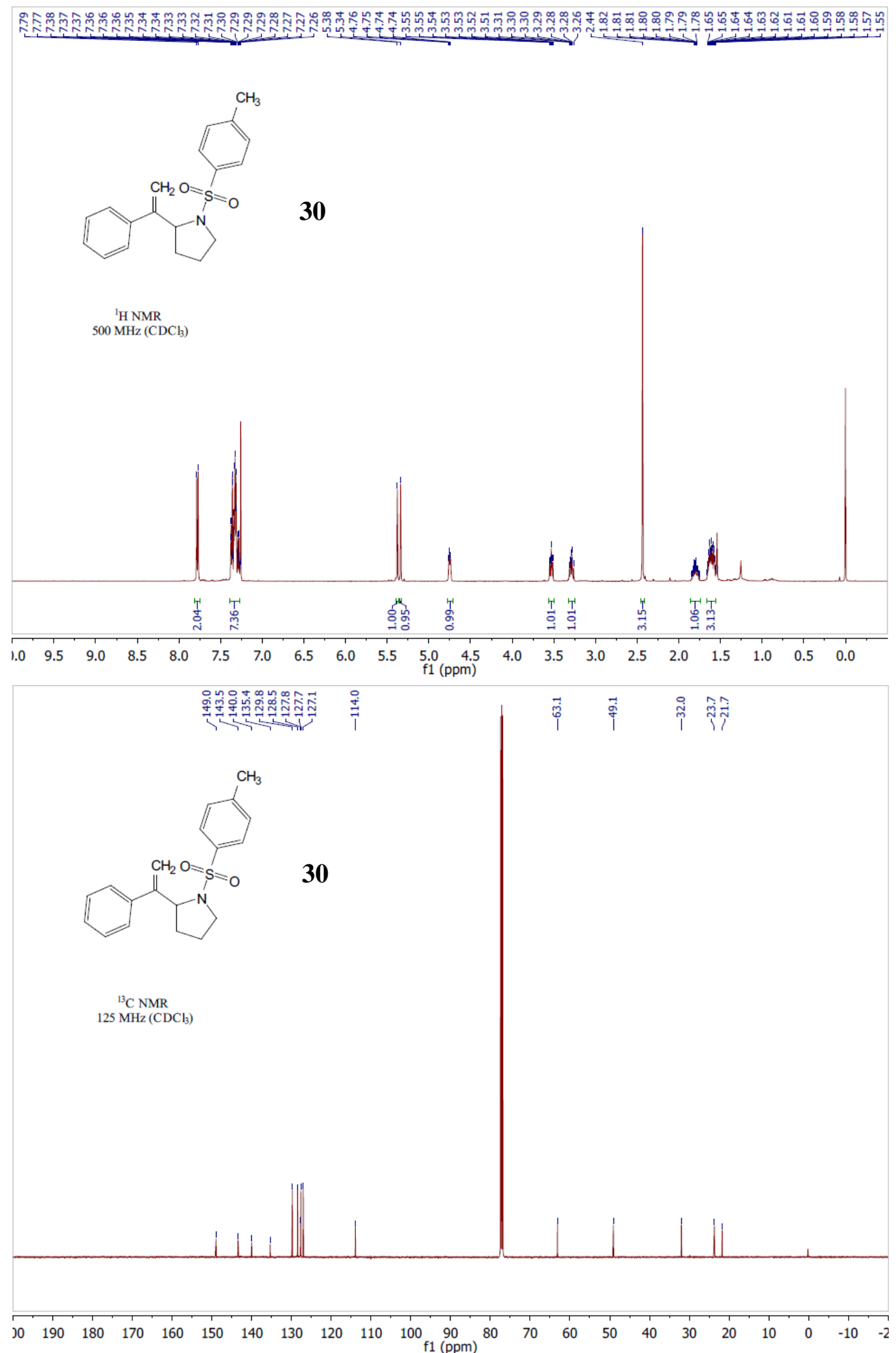

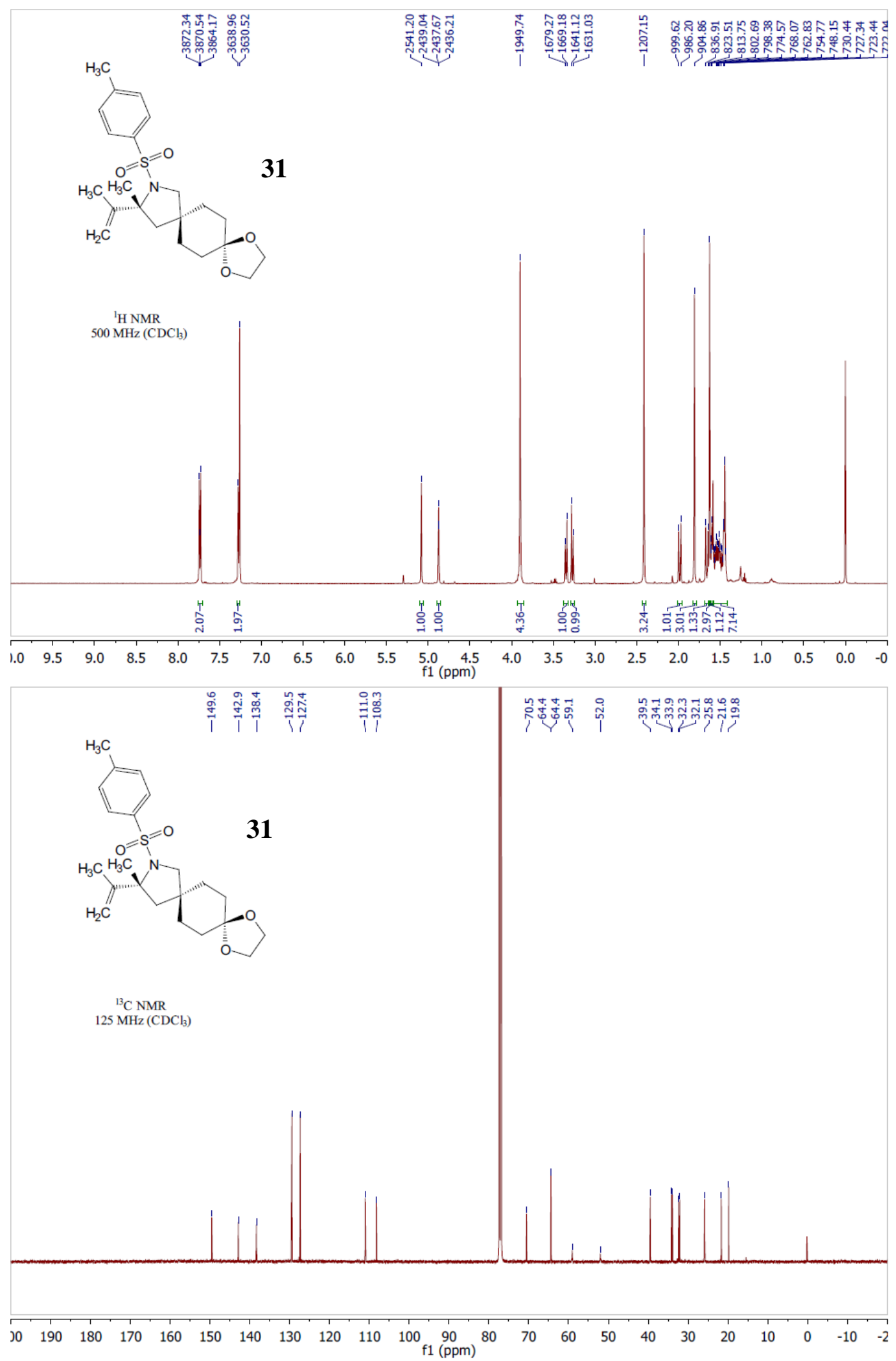


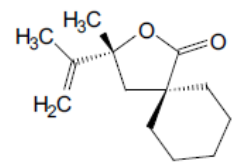

32

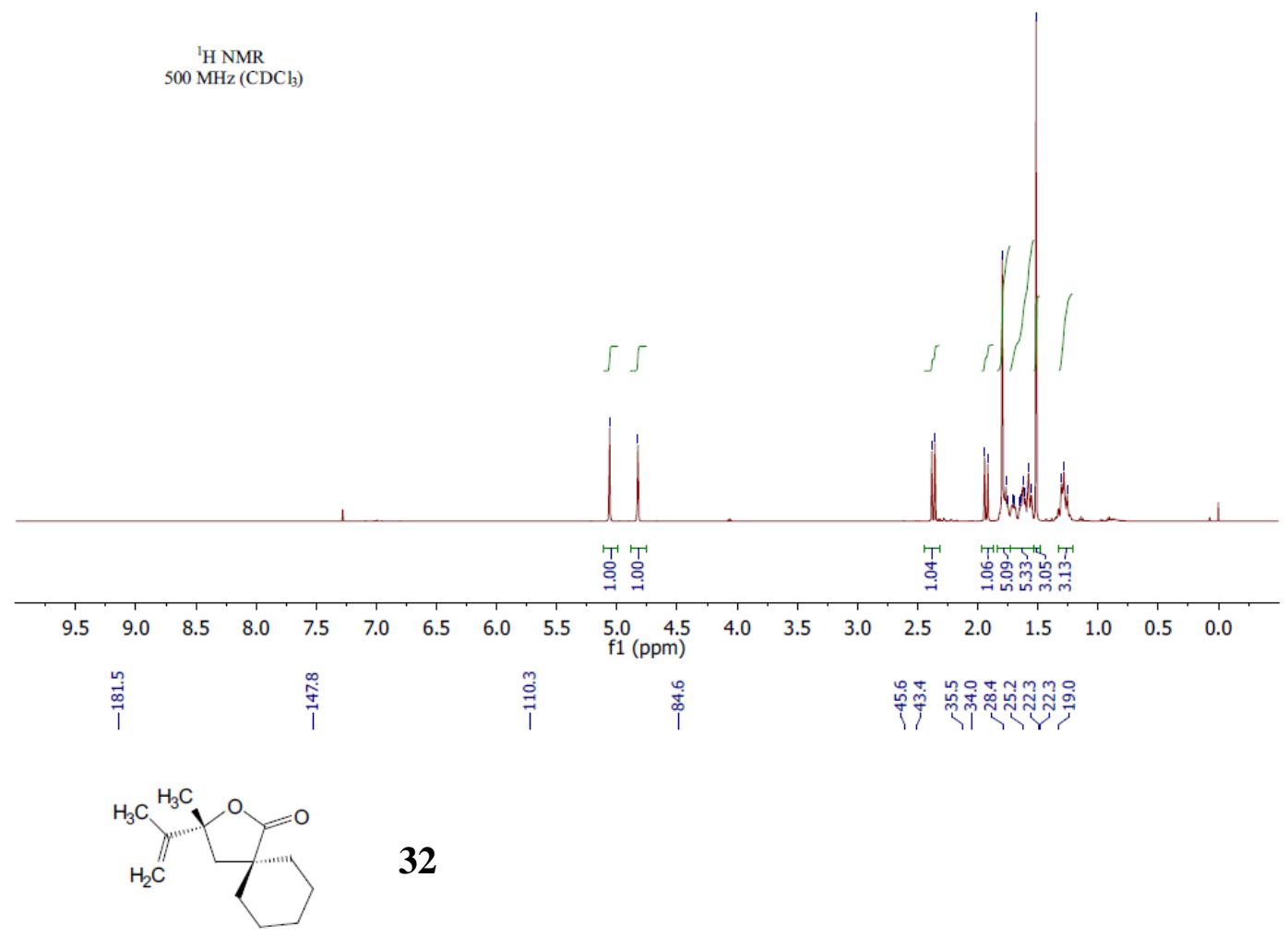

${ }^{13} \mathrm{C}$ NMR $125 \mathrm{MHz}\left(\mathrm{CDCl}_{3}\right)$

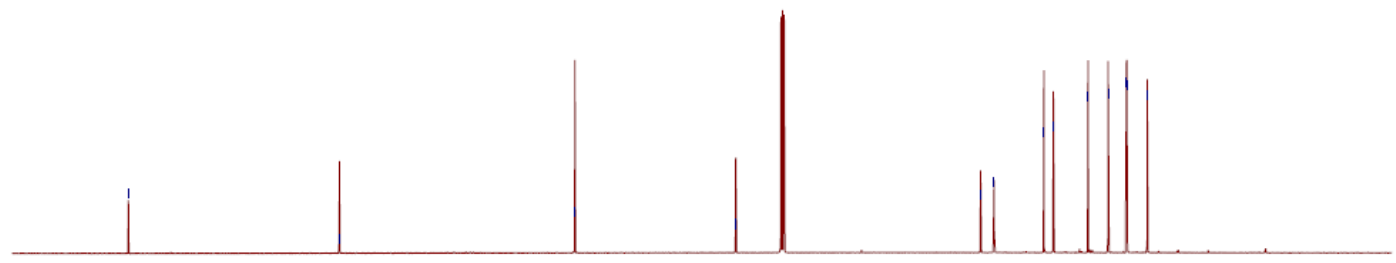

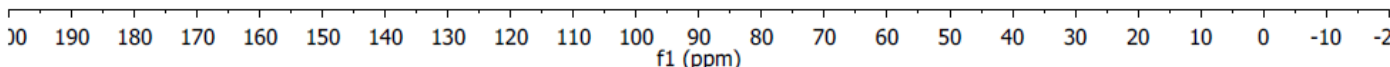




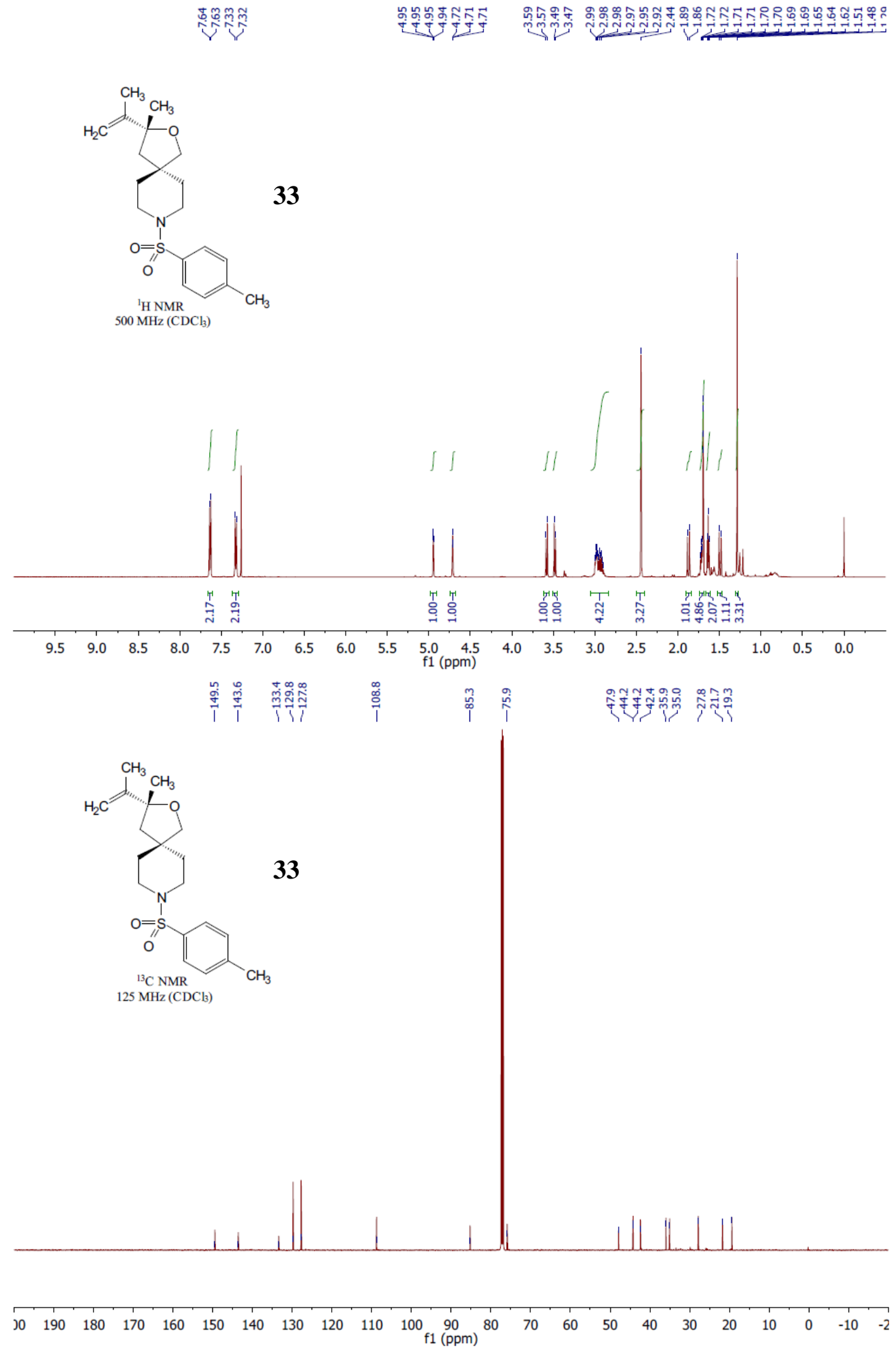

